\author{
UNIVERSIDADE DE SÃO PAULO \\ Faculdade de Filosofia, Letras e Ciências Humanas \\ Departamento de Geografia \\ Programa de Pós-Graduação em Geografia Humana
}

\author{
MUDANÇAS HISTÓRICAS E IMPLICAÇÕES SÓCIO- \\ ESPACIAIS NA COMPOSIÇÃO DAS ATIVIDADES \\ AGROPECUÁRIAS HEGEMÔNICAS \\ NA REGIÃO DE ARAÇATUBA (SP)
}

Danton Leonel de Camargo Bini

\begin{abstract}
Dissertação apresentada ao Programa de Pós-Graduação em Geografia Humana do Departamento de Geografia da Faculdade de Filosofia, Letras e Ciências Humanas da Universidade de São Paulo, para Obtenção do título de Mestre em Geografia Humana.
\end{abstract}

Orientadora: Profa. Dra. Rosa Ester Rossini

SÃO PAULO

2008 


\title{
Mudanças Históricas e Implicações Sócio-Espaciais na \\ Composição das Atividades Agropecuárias Hegemônicas na \\ Região de Araçatuba (SP)
}

Palavras-Chave: café, algodão, pecuária bovina, cana-de-açúcar, urbanização.

\section{Resumo:}

Durante sua história, a região de Araçatuba, após o domínio indígena, presenciou a ocupação de algumas culturas - café, algodão, pecuária bovina e cana-de-açúcar - que hegemonizaram o uso de suas terras agrícolas. Nesse trabalho apresentamos esses vários momentos da ocupação do espaço geográfico regional e algumas implicações sócio-espaciais resultantes desses processos.

\section{Historical Changes and Sócio-Spacial Implication on the Hegemonic Agricultural Activities Composition in the Region of Araçatuba, State of São Paulo, Brazil}

Key words: coffee, cotton, catle breeding, sugar cane, urbanization.

\begin{abstract}
Abstrat:
Along the history of this region, after the aboriginal occupation, some craps - coffee, cotton, and sugar cane - as well as catle breeding occupied hegemonically the tillable lands. Several moments of the occupation of the regional geographic space and some socio-spatial consequences resulting from this process are presented.
\end{abstract}


À minha família e aos meus amigos

dedico este trabalho. 


\section{Agradecimentos}

Primeiramente, agradeço a Secretaria de Educação do Estado de São Paulo pelo oferecimento da bolsa mestrado nos concedida entre agosto de 2005 e fevereiro de 2008. Agradeço também à Secretaria de Agricultura e Abastecimento do Estado de São Paulo, especificamente o Instituto de Economia Agrícola, pela generosidade durante todas as etapas de minha vida acadêmica, desde 1998 até o momento atual: a compreensão e ensinamentos apresentados por Ana Maria Montragio Pires de Camargo, Ana Maria Pereira Amaral, Alessandra Sampaio Pedrosa, Andresa Rocha Carrilho, Alceu de Arruda Veiga Filho, Carlos Eduardo Fredo, Carlos Roberto Ferreira Bueno, Carolina Aparecida Pinsuti, Celma da Silva Lago Baptistella, Denise Viani Caser, Francisco Alberto Pino, Felipe Pires de Camargo, Getúlio Benjamin da Silva, Irene Francisca Lucatto, José Alberto Ângelo, Maria Carlota Meloni Vicente, Maria Cristina Teixeira Jesus Rowies, Mario Pires de Almeida Olivetti, Ozeneide Dantas Xavier da Silva, Raquel Castellucci Caruso Sachs, Roberto de Assumpção, Santina Aparecida de Toledo, Tânia Regina de Oliveira da Silva, Valquiria da Silva, Vera Lúcia dos Santos Francisco e Yara de Cássia Corrêa Silva, nos auxiliaram bastante.

À Profa. Rosa Ester Rossini pela disciplina, embasamento, orientação e carinho nos oferecidos no discorrer de todos esses anos: muito obrigado! No LABOPLAM, agradeço principalmente a Ana Pereira e Aline Santos. No Departamento de Geografia da USP, além dos funcionários da Secretaria de Pós-Graduação, que me tiraram muitas dúvidas referentes aos desencadeares administrativos da instituição em relação à prazos e documentos, destaco os aprendizados obtidos junto à Profa. Mônica Arroyo, tanto na disciplina ministrada "Território e Circulação", quanto nas observações realizadas durante a qualificação dessa dissertação. Por todos vocês, sou muito grato. No NEMGE, meus agradecimentos ao Wilson. 
Em Araçatuba e região, além de toda minha família, sou grato ao Prof. Antônio César Salibe, da UDOP (União dos Produtores de Bionergia) e ao Dr. Claudionor Aguiar Teixeira, que respectivamente especialistas em cana-de-açúcar e pecuária bovina de corte, nos abriram as portas para contatos mais aprofundados com os setores e a realidade histórica regional. À Câmara Municipal de Araçatuba, meu muito obrigado pelo acesso ao seu acervo de fotos históricas. Aos professores Euclides Garcia Paes de Almeida e Pascoal Manfredi Neto também agradeço pelos ensinamentos oferecidos durante a realização desse trabalho.

São Paulo, outubro de 2008. 


\section{Sumário}

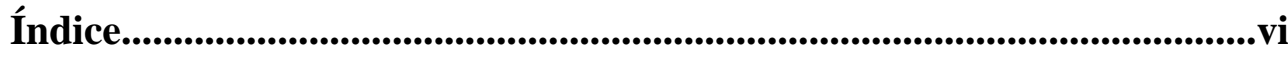

Índice de Ilustrações (Mapas)................................................................viii

Índice de Ilustrações (Figuras).....................................................................viii

Índice de Ilustrações (Fotos).......................................................................ix

Índice de Tabelas.................................................................................................xii

Introdução..........................................................................................................................1

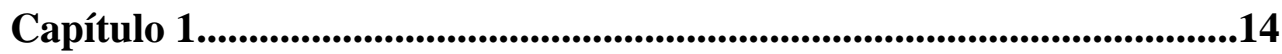

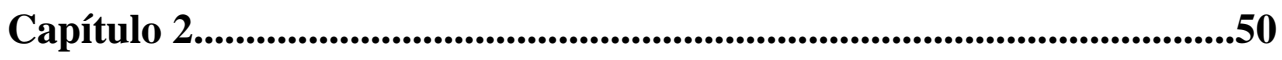

Capítulo 3............................................................................................................65

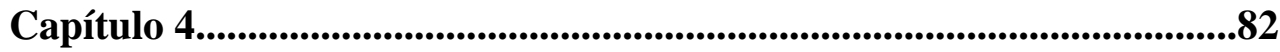

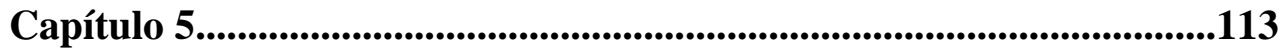

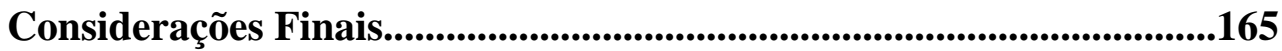




\section{Índice}

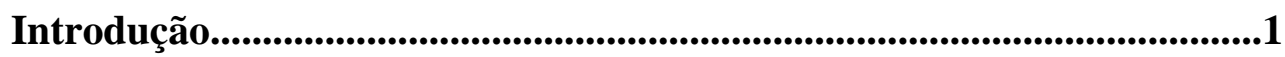

a) A Área de Estudo no Contexto da Divisão Territorial do Estado de São Paulo: a região de Araçatuba...................................................................1

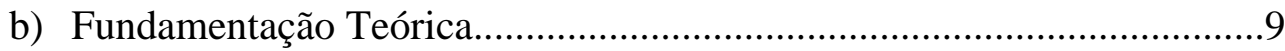

c) Apresentação da pesquisa...............................................................13

Capítulo 1 - Do Extermínio dos Indígenas Caingangues à Ocupação da Cultura Cafeeira...............................................................................14

1.1) Os Indígenas Caingangues.........................................................14

1.2) A Mecanização do Espaço Geográfico Paulista e a Cultura

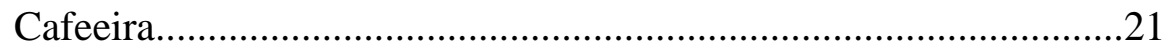

1.2.1) O Café, a Ferrovia e seus Atores Hegemônicos...............................23

1.2.2) A Formatação da Espacialidade Capitalista na Província de São Paulo e na Região de Araçatuba......................................................26

1.2.3) As Ferrovias no Espaço Geográfico Paulista....................................27

1.2.4) A Companhia Estrada de Ferro Noroeste do Brasil

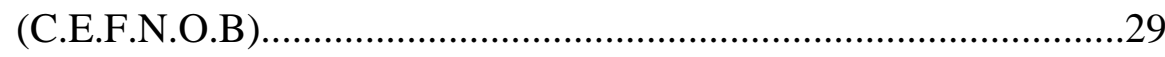

1.2.5) A Ocupação das Terras da Região de Araçatuba.............................32

\section{Capítulo 2 - 0 Circuito Produtivo Algodoeiro na Região de}

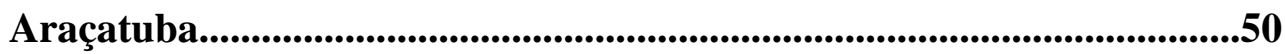

2.1) Novos Conteúdos do Momento Algodoeiro.........................................52

\section{Capítulo 3 - O Circuito Pecuário na Região de Araçatuba......................65}

3.1) A Hegemonização da Pecuária Bovina de Corte na Região de Araçatuba em Meados do Século XX......................................................68

3.2) Algumas Implicações Sócio-Espaciais da Expansão da Pecuária Bovina de Corte na Região de Araçatuba................................................................75 
Capítulo 4 - Modernização do Território Brasileiro: A Agricultura e Algumas Implicações na Região de Araçatuba.......................................82

4.1) As Mudanças no Campo Brasileiro.......................................................85

4.2) Algumas Mudanças na Pecuária de Corte na Região de Araçatuba nos

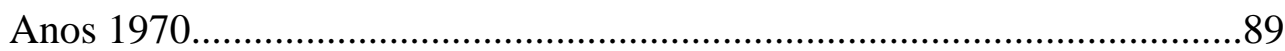

4.3) O Proálcool na Região de Araçatuba na Década de 1980......................98

Capítulo 5 - As Reformas dos Anos 1990: A Reestruturação Produtiva do Espaço Geográfico.........................................................................113

5.1) Reestruturação Produtiva na Agricultura..........................................116

5.2) A Região de Araçatuba no Limiar do Século XXI..............................118

5.3) Revitalização do Proálcool nos Últimos Anos e Rearticulação do Circuito Produtivo Canavieiro na Região de Araçatuba...............................123

5.3.1) A Desregulamentação do Setor Sucroalcooleiro no Atual Período

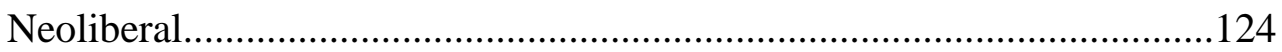

5.3.2) A Expansão Canavieira na Região de Araçatuba nos Anos 2000 e Algumas Implicações Sócio-Espaciais.................................................129 5.4) Algumas Mudanças na Pecuária Bovina e Outras Culturas Agrícolas na Região de Araçatuba no Início dos Anos 2000 154

Considerações Finais .165 


\section{Índice de Ilustrações (Mapas)}

Mapa 1: Estado de São Paulo e Região Administrativa de Araçatuba em

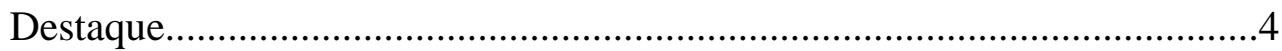

Mapa 2: Região Administrativa de Araçatuba................................................5

Mapa 3: Regiões Administrativas e de Governo do Estado de São Paulo.....6

Mapa 4: Malha Ferroviária Constituída no Espaço Geográfico Paulista.....45

Mapa 5: Área de Influência sob Pretensão de Representatividade pelos Usineiros da Região de Araçatuba...........................................................131

Mapas 6 e 7: Relação das Áreas de Ocupação de Cana-de-açúcar no Centro-

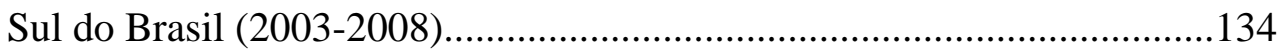

Mapa 8: Transcurso da Hidrovia Tietê-Paraná..........................................146

Mapa 9: Distribuição de Bovinos no Território Brasileiro (1995-1996)....156

Mapa 10: Distribuição de Bovinos no Território Brasileiro (2006)............157

\section{Índice de Ilustrações (Figuras)}

Figura 1: Divisor de Águas entre os Rios Feio e Tietê .40 


\section{Índice de Ilustrações (Fotos)}

Foto 1: Caingangues em Canoa no Início do Século XX .15

Foto 2: Planalto Ocidental Paulista na Região de Araçatuba antes da Expansão do Modo de Produção Capitalista .16

Foto 3: Rio na Hinterlândia de Araçatuba Registrado no Início do Século $\mathrm{XX}$

Foto 4: Desbravadores em Incursão Financiada pela Elite Cafeicultora

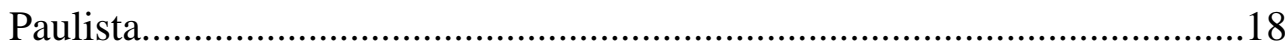

Foto 5: Indígena Caingangue Realizando "Picada” dentro da Mata............19

Foto 6: Aldeia Caingangue no Início do Século XX....................................20

Foto 7: Tropa de Bovinos Transportadora de Mercadorias na Região de

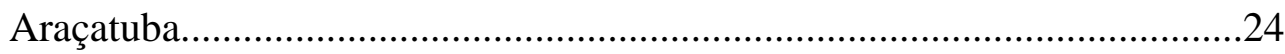

Foto 8: Primeira Estação Ferroviária em Araçatuba.....................................30

Foto 9: Segunda Estação Ferroviária em Araçatuba.....................................31

Foto 10: Fachada Lateral da Terceira Estação Ferroviária de Araçatuba.....35

Foto 11: Panorâmica da Centralidade Surgida ao Redor de Estação Ferroviária na Região de Araçatuba..........................................................36

Foto 12: Contato Negociador dos Índios Caingangues com Representante do

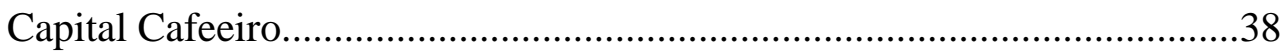

Foto 13: Estrada Aberta no Meio da Mata do Planalto Ocidental

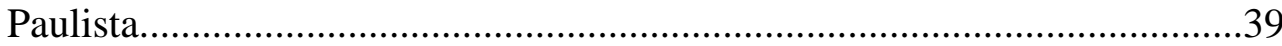
Foto 14: Clareira Aberta por Queimada para Instalação da Lavoura de

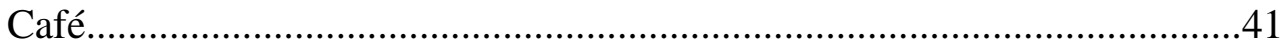

Foto 15: Colheita de Café em Colônia Japonesa na Região de

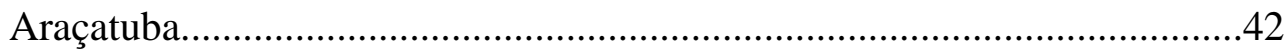

Foto 16: Balsa (Ferroboaty) Usada para Travessia de Rio...........................44

Foto 17: Estação Ferroviária de Andradina...................................................46

Foto 18: Panorâmica da Expansão Urbana de Araçatuba nas Primeiras Décadas (fotografia tirada da periferia da cidade). 
Foto 19: Vista Parcial da Expansão Urbana de Araçatuba nas Primeiras Décadas (fotografia tirada do centro da cidade)..........................................48

Foto 20: Colônia Rural Japonesa na Hinterlândia de Araçatuba..................49

Foto 21: Indústria Beneficiadora de Algodão SANBRA em Araçatuba (Anos 1930-1940). .53

Fotos 22 e 23: Embarques de Algodão em Colônias Japonesas Rumo à

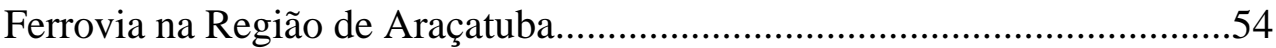

Foto 24: Antiga Estrada Araçatuba-Birigui...................................................56

Fotos 25 e 26: Plantio de Arroz e Criação de Porcos, Respectivamente, em Colônia Japonesa na Região......................................................................57

Fotos 27, 28, 29, 30 e 31: Respectivamente - Primeira Agência dos Correios; Antiga Central de Iluminação Pública; Antigo Posto de Gasolina; Cinema Antigo; Escola...................................................................................58

Foto 32: Boiadeiros e Boiada nos Arredores de Araçatuba em torno dos Anos 1940 - 1950 69

Fotos 33 e 34: Frigorífico TMaia em Araçatuba em torno dos Anos 1960 .73

Fotos 35 e 36: Vagões Próprios do TMaia Transportadores de Carne..........74

Fotos 37 e 38: Kavardi Embalsamado no Museu da Chácara Zebulândia, em Araçatuba .90

Foto 39: Panorâmica Aérea da Usina Campestre, em Penápolis .99

Fotos 40, 41, 42 e 43: Processo de Seleção e Melhoramento Genético de Cana-de-Açúcar na Estação Experimental de Valparaíso (SP)...................101

Foto 44: Retrato da Verticalização Central de Araçatuba..........................109

Foto 45: Sala de Comando Informatizado na Usina Equipav Promissão (SP). 126

Foto 46: Usina Benalcool (Grupo Cosan) em Bento de Abreu (SP)..........132

Foto 47: Canaviais Margeando Rodovia Vicinal na Região de Araçatuba. .135

Foto 48: Queimada em Canavial na Região de Araçatuba..... 136

Foto 49: Alojamento de Cortadores de Cana Migrantes na Região de Araçatuba. 138 
Foto 50: Estrada Vicinal Nametala Rezek na Região de Araçatuba...........142

Foto 51: Trilhos e Vagões na Região de Araçatuba...................................143

Foto 52: Abastecimento de Açúcar em Vagão no Terminal Rodoferroviário

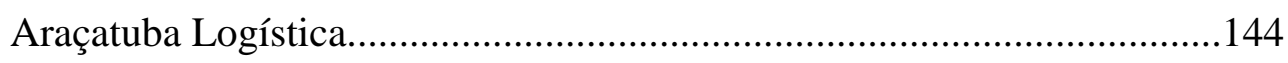

Foto 53: Terminal Rodoferroviário Araçatuba Logística...........................145

Foto 54: Barcaça Navegando na Hidrovia Tietê-Paraná..............................148

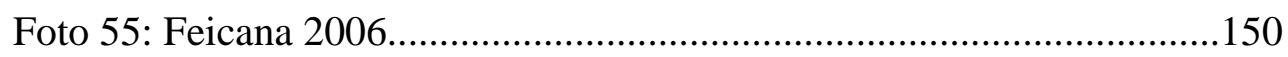

Fotos 56, 57, 58, 59 e 60: Confinamento para Bovinos de Corte na Região

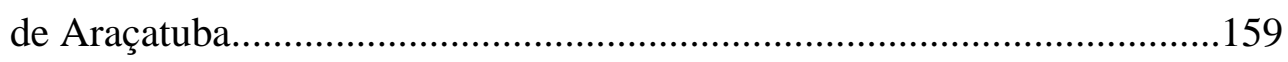

Foto 61: Veterinário de Araçatuba Realizando Rastreabilidade de Bezerros de Elite (Futuros Reprodutores) em Banco de Dados Informatizado Cadastrado na Associação Brasileira de Criadores de Zebu

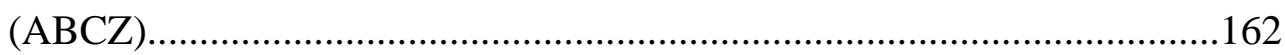




\section{Índice de Tabelas}

Tabela 1: Divisão dos Municípios da Região Administrativa de Araçatuba entre as Regiões de Governo.. .7

Tabela 2: Distribuição das Aglomerações Humanas na Região de Araçatuba Segundo Classes de População - (1940)... .61

Tabela 3: Região de Araçatuba - População e Taxas Anuais de Crescimento Populacional por Sub-Região 1940-1950. .62

Tabela 4: Distribuição das Aglomerações Humanas na Região de Araçatuba Segundo Classes de População - (1950). 63

Tabela 5: Brasil - Desenvolvimento da Rede de Estradas Federais, Estaduais e Municipais (Km): 1952-1965 .67

Tabela 6: Região de Araçatuba - População e Taxas Anuais de Crescimento Populacional por Sub-Região 1950-1960 .76

Tabela 7: Região de Araçatuba - População e Taxas Anuais de Crescimento Populacional por Sub-Região 1960-1970 ....................................................76

Tabela 8: Município de Clementina - População Urbana, Rural e Total

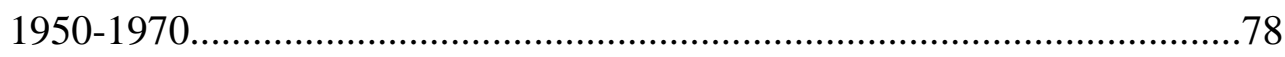

Tabela 9: Região de Araçatuba - Distribuição Setorial do Emprego (\%) 1950-1970. .79

Tabela 10: Distribuição das Aglomerações Humanas na Região de Araçatuba Segundo Classes de População (1960-1970)..... .80

Tabela 11: Número e Percentual de Bovinos de Corte por Divisão Regional Agrícola do Estado de São Paulo, 1973.....................................................91

Tabela 12: Região de Araçatuba - População Urbana, Rural e Taxa de

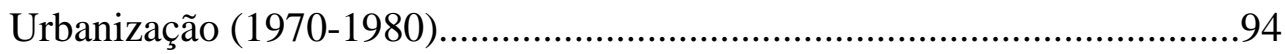

Tabela 13: Região de Araçatuba - População e Taxas Anuais de Crescimento Populacional por Sub-Região 1970-1980...............................95

Tabela 14 - Área Cultivada (em hectares) das Principais Atividades Agrícolas Observadas na Divisão Agrícola de Araçatuba (1969-1980).......96 Tabela 15: Distribuição das Aglomerações Humanas na Região de Araçatuba Segundo Classes de População (1980).........................................97 
Tabela 16 - Evolução da Área Total Plantada com Cana-de-Açúcar, por Divisão Regional Agrícola, Estado de São Paulo, 1970/1971 - 1985/1986 (em hectares)... .105

Tabela 17: Região de Araçatuba - Área de Ocupação das Pastagens, Número do Rebanho Bovino e Relação Bovinos/Ha (1970-1990)............................107 Tabela 18: Região de Araçatuba - População Urbana, Rural e Taxa de Urbanização (1980-1991)........................................................................108

Tabela 20: Distribuição das Aglomerações Humanas na Região de Araçatuba Segundo Classes de População (1991).......................................110 Tabela 21: Região de Araçatuba - População e Taxas Anuais de Crescimento Populacional por Sub-Região 1980-1991..............................110 Tabela 22: Região de Araçatuba - Área de Ocupação das Pastagens, Número do Rebanho Bovino e Relação Bovinos/Ha (1990 - 2000).........................119 Tabela 23: Região de Araçatuba - População e Taxas Anuais de Crescimento Populacional por Sub-Região 1991-2000...............................120 Tabela 24: Distribuição das Aglomerações Humanas na Região de Araçatuba Segundo Classes de População (2000)......................................121

Tabela 25: Região de Araçatuba - População Urbana, Rural e Taxa de Urbanização (1991-2000)...... 121

Tabela 26 - Evolução da Área Total Plantada com Cana-de-Açúcar para Indústria, por Região Administrativa do Estado de São Paulo, 1990-2007 (em hectares) 133

Tabela 27: Região de Araçatuba - População e Taxas Anuais de Crescimento Populacional por Sub-Região 2000-2007. 137

Tabela 28: Região de Araçatuba - População Urbana, Rural e Taxa de Urbanização (2000-2007). 139

Tabela 29: Distribuição das Aglomerações Humanas na Região de Araçatuba Segundo Classes de População (2007). .140 
Tabela 30: Evolução da Área de Pastagens (em hectares) e Rebanho Bovino por Região Administrativa do Estado de São Paulo, 2000 -

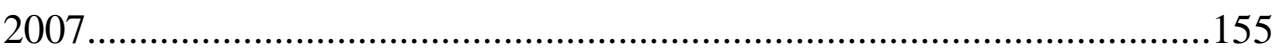

Tabela 31: Região de Araçatuba - Área de Ocupação das Pastagens, Número do Rebanho Bovino e Relação Bovinos/Ha (2000 - 2007)..........................160 


\section{Introdução}

\section{a) A Área de Estudo no Contexto da Divisão Territorial do Estado de São}

\section{Paulo: a região de Araçatuba}

Do início da ocupação capitalista na primeira década do século XX até os anos de 1950, o que classificamos hoje como Região Administrativa de Araçatuba não existia como delimitação oficial rígida e precisa. As regiões ou sub-divisões do espaço geográfico do estado de São Paulo apenas indicavam as grandes áreas de ocupação conquistadas pela elite paulista através da instalação das ferrovias. As regiões eram denominadas segundo a formatação das companhias ferroviárias que no espaço geográfico se anexaram. No caso do que é hoje a Região Administrativa de Araçatuba, tínhamos a Noroeste, onde os municípios de Penápolis, Birigui e Araçatuba apareciam como os mais importantes. Bragantina, Mogiana, Araraquarense, Alta Araraquarense, Paulista, Alta Paulista, Sorocabana, Alta Sorocabana eram as outras regiões também nomeadas pelas companhias ferroviárias.

A partir da década de 1950, o governo do estado de São Paulo, seguindo as indicações teóricas hegemônicas de planejamento estatal, como a teoria dos pólos de desenvolvimento, começa a pensar em dividir o seu território em regiões administrativas para fins de planejamento e gestão de suas políticas públicas (Hespanhol, 1996). O primeiro estudo de origem institucional, denominado “Problemas de Desenvolvimento - Necessidades e Possibilidades do Estado de São Paulo”, foi realizado em 1954 pela Sociedade de Análises Gráficas e Mecanográficas Aplicadas aos Complexos Sociais SAGMACS, em conjunto com a Comissão Interestadual da Bacia Paraguai e Uruguai - CIBPU. Este trabalho recomendou a regionalização do estado, definindo fragmentos territoriais como “Unidades de Organização e Aproveitamento”. Colocava-se a necessidade de constituição de unidades territoriais intermediárias entre os municípios e o estado - a região - para assegurar um melhor aproveitamento, valorização e desenvolvimento mais rápido do território estadual.

Dois outros trabalhos podem ser destacados no período: "II Plano de Ação de Governo (1959 - 1963)” e o “Plano de Desenvolvimento Integrado” (PLADI - 1964-1966). Ambos objetivavam intensificar o desenvolvimento, 
promovendo o aumento da produtividade e da produção através de aplicações maciças na infra-estrutura da economia como energias, ferrovias, aeroportos, pontes, armazéns, centros de abastecimento, etc.

Na década de 60 tivemos também a criação da Secretaria de Economia e Planejamento, que em um convênio com a Universidade de São Paulo (FAUUSP) realizaram um projeto para implementar a regionalização de todos os setores da política pública - educação, saúde, agricultura, etc. Em 1967, pelo Decreto n ${ }^{0}$. 48.162 - alterado pelo Decreto $\mathrm{n}^{0} .52 .576$ de 1970, institui-se oficialmente a primeira divisão regional do estado. A nova organização regional, cujas regiões ficaram conhecidas por Regiões Administrativas (RA), foi delimitada segundo critérios de polarização, considerando-se o tempo de acessibilidade dos diversos municípios ao pólo regional e à população total polarizada por parte de cada região e sub-região. Esta regionalização dividiu o Estado em 11 regiões e 48 subregiões, consideradas unidades territoriais polarizadas ${ }^{1}$.

Na sede de cada Região Administrativa foi criado o Escritório Regional de Planejamento - ERPLAN. A intenção era tornar cada Escritório um centro de planejamento, articulando e orientando os dirigentes regionais quanto às ações do Estado e, transformando-o assim, em núcleos de estudos e pesquisas. Para a Grande São Paulo foi criado o GEGRAN (Grupo Executivo da Grande São Paulo).

De 1970 a 1983, as únicas mudanças ocorridas, influenciadas pelo Programa Nacional para as Cidades de Porte Médio (braço do II PND -1975 a 1979) foram as criações de novas Regiões Administrativas, a partir da fragmentação das já existentes. Em agosto de 1984, foi implantado o novo modelo regional através do Decreto $\mathrm{n}^{0}$ 22.592, reorganizando o estado em 42 regiões de governo dentro das 11 Regiões Administrativas. Por exemplo, a R. A. de Araçatuba foi dividida em duas Regiões de Governo (R.G.): R.G. de Andradina e R.G. de Araçatuba. As R.G.s nada mais eram do que sub-regiões responsáveis por algumas funções administrativas setoriais em diferenciação dentro das R. A.s. A aproximação da gestão estadual nas execuções locais de suas políticas públicas foi o principal argumento usado para essa nova normatização.

1 http://www.seade.gov.br/produtos/anuario/2003/index.php?tip=ment\&opt=notas\&cap=1\&tema=car; Acesso Disponível em 04/09/2008. 
Entre 1987 e 1994, os Escritórios Regionais de Governo (ERG) se fundiram aos ERPLANs nas cidades pólos das Regiões Administrativas. Transformaram-se primeiramente em Escritórios Regionais de Planejamento (ERP), passando à subordinação da Secretaria de Economia e Planejamento de 1987 a 1991. Depois, entre 1991 e 1994, foram denominados Escritórios Regionais de Integração (ERI), vinculados à Secretaria de Governo no período de 1991 a 1992 e, à Secretaria de Planejamento e Gestão, nos anos de 1992 em diante.

Atualmente, após mudanças pontuais em alguns fragmentos do espaço geográfico paulista, a divisão político-administrativa do Estado compõe-se de 15 Regiões Administrativas - A Região de Araçatuba é uma delas - e 42 Regiões de Governo - com a RA de Araçatuba possuindo as RGs de Andradina e Araçatuba ${ }^{2}$. Além dessas, em análise do relatório do Anuário Estatístico de 2003 da Fundação SEADE (Fundação Sistema Estadual de Análise de Dados) ${ }^{3}$, podemos ver outras tantas divisões regionais por setor de política pública (Secretarias), cada uma com um engessamento dado pelas forças político-partidárias existentes.

\footnotetext{
${ }^{2}$ Além de serem consideradas Regiões Administrativas (RAs), São Paulo, Campinas e Santos, devido às características de suas conformações sócio-territoriais se apresentam diferenciadamente para a gestão do governo paulista respectivamente como Regiões Metropolitanas de São Paulo, Campinas e da Baixada Santista.

${ }^{3}$ http://www.seade.gov.br/produtos/anuario/2003/1_intro.pdf
} 
Mapa 1: Estado de São Paulo e Região Administrativa de Araçatuba em Destaque

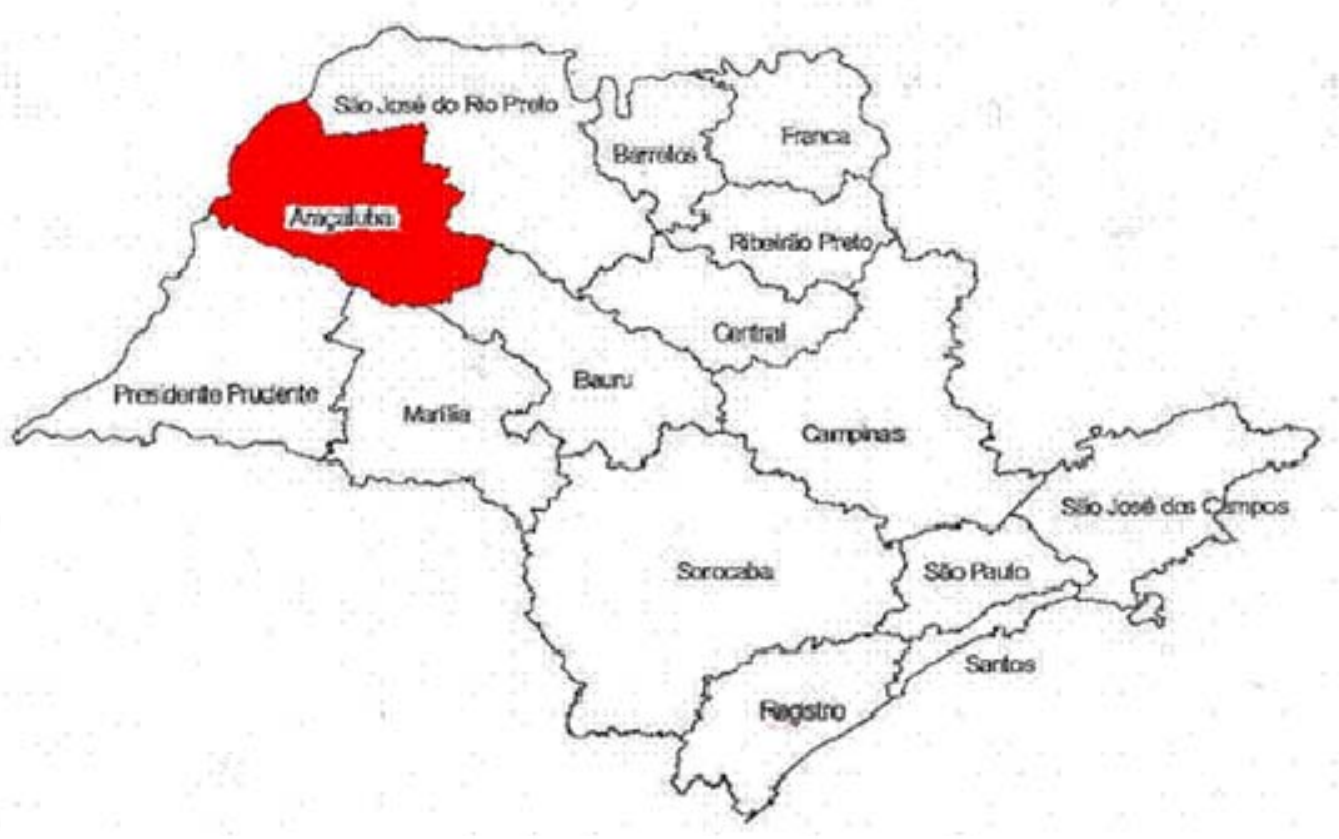

Fonte: SEADE, Readaptado (2008). 
Mapa 2: Região Administrativa de Araçatuba

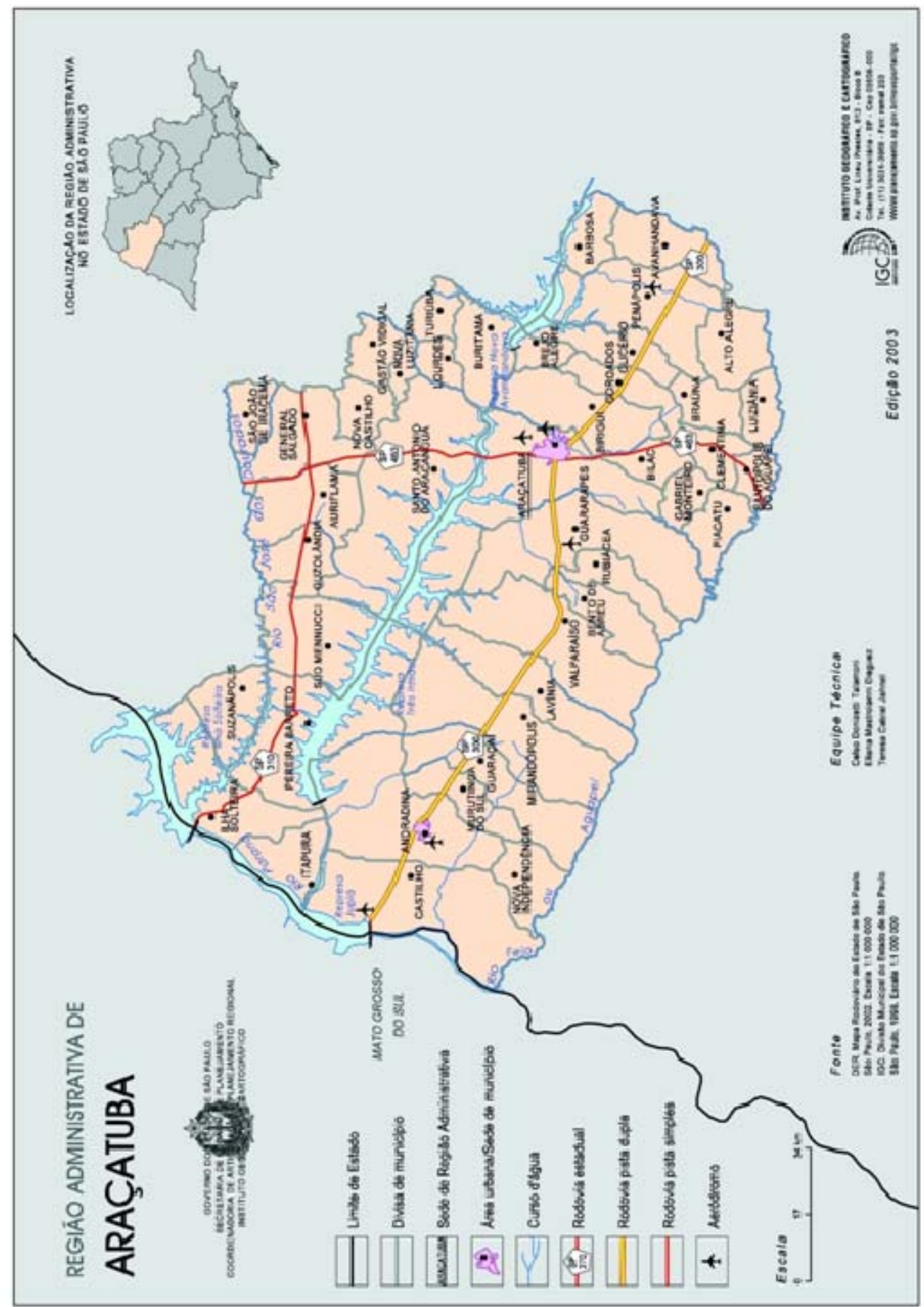

Fonte: Instituto Geográfico e Cartográfico (IGC, 2003). 


\section{Mapa 3: Regiões Administrativas e de Governo do Estado de São Paulo}

CARACTERIZAÇĀO DO TERRITÓRIO: DIVISĀO, POSIC̣:ĀO E EXTENSĀO

Mapa 1

Divisão Político-Administrativa

Regiōes Adminis trativas, Regiöes de Govemo e Regiōes Metropolitanas

2003

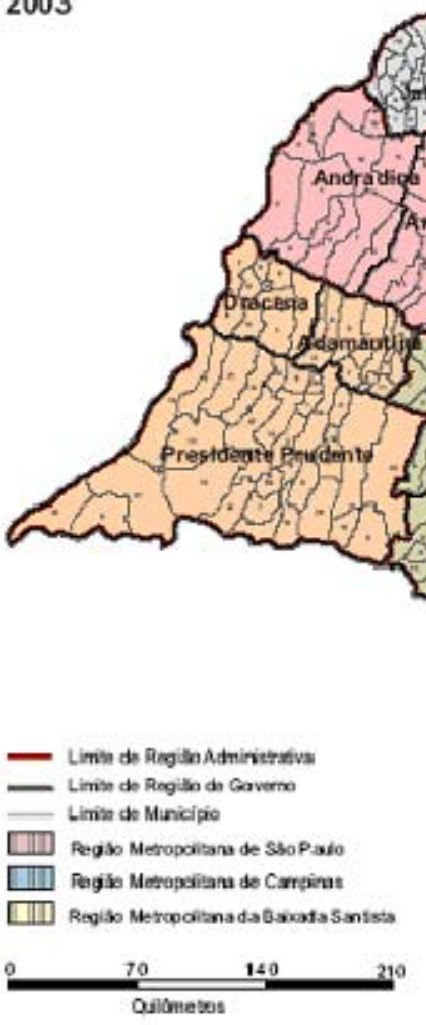

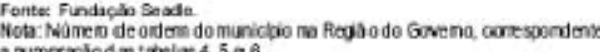

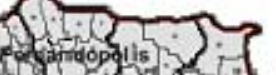

Anuário Estatístico do Estado de São Poulo 2003

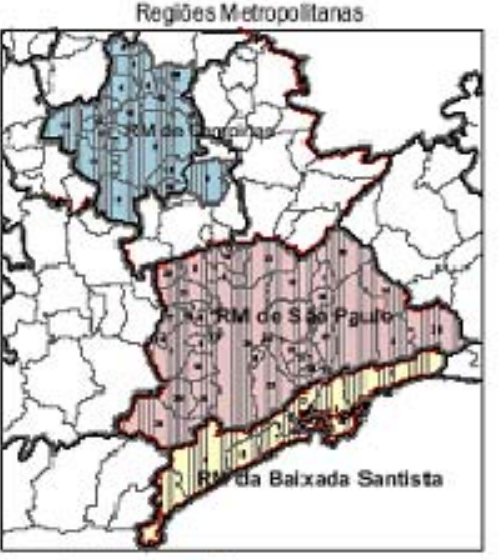

Co Gove mo e Regiôes Me tropolitanas
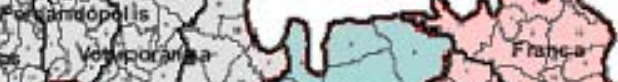

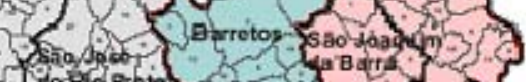

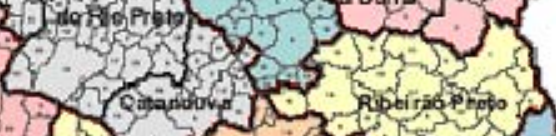

37 . 3 ,

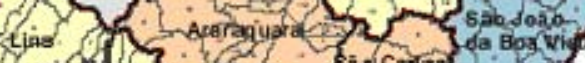

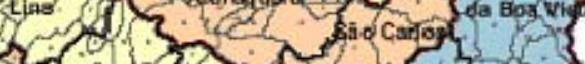
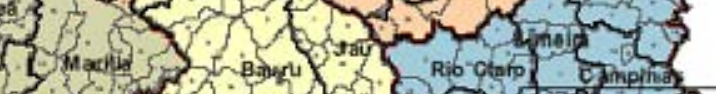

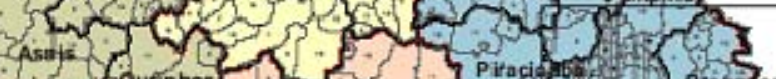

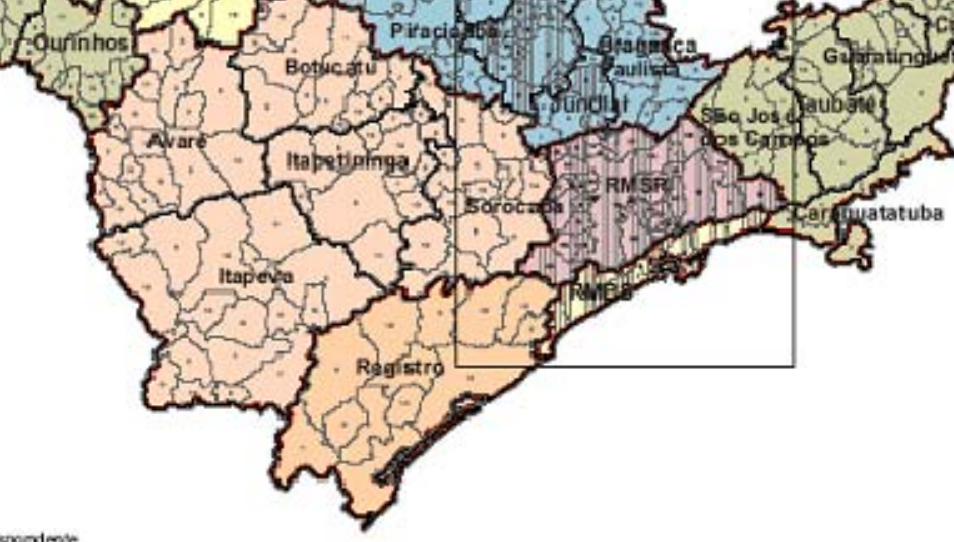

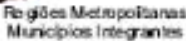


Tabela 1: Divisão dos Municípios da Região Administrativa de Araçatuba entre as Regiões de Governo

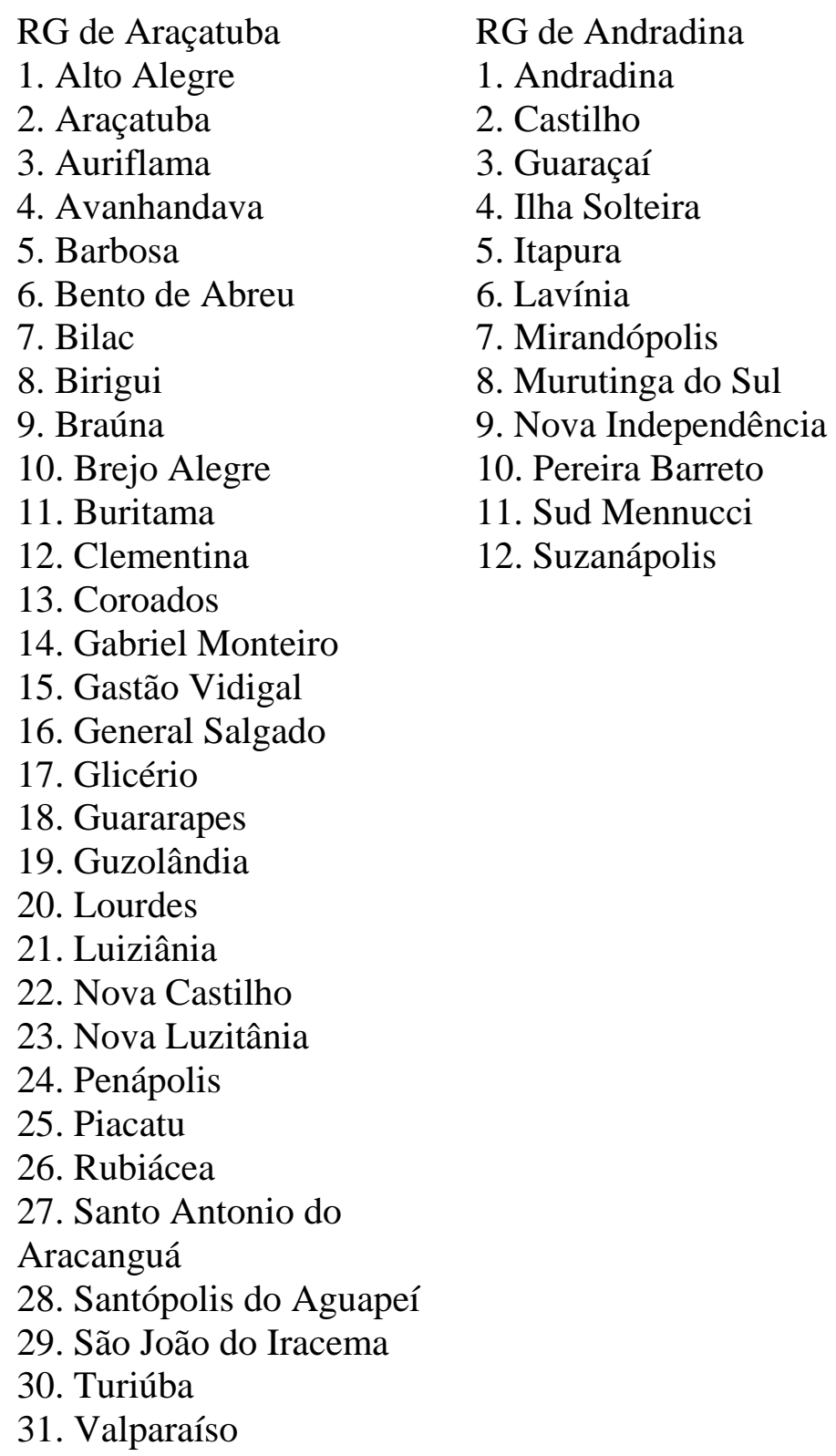

Fonte: Anuário Estatístico do Estado de São Paulo, SEADE, 2003. 
É a partir da racionalização contraditória dessa formatação oficial rígida, tendo o município de Araçatuba como pólo regional, que partiremos nossa análise. Sendo os dados estatísticos colhidos a partir dessa formatação, escolhemo-la como ponto de partida. Contudo, entendendo que a região não pode ser trabalhada como um subespaço estável e fechado em si, buscaremos captar os eventos regionais (re)produtores do espaço geográfico enquanto materialização em conexão com outras escalas, num processo de totalização parcial do mundo em movimento (Silveira, 1997). 


\section{b) Fundamentação Teórica}

Embasados teoricamente nos escritos de Milton Santos, - em suas principais obras relacionadas a uma teoria e a um método da ciência geográfica - iniciaremos a discussão do trabalho pelo objeto da ciência geográfica: o espaço geográfico (Santos, 1978;1988;1994;2002).

Assim, temos por espaço geográfico a parte da natureza modificada pelo trabalho humano durante o processo histórico. No estágio das relações sociais atingidas atualmente, têm-se praticamente a totalidade da natureza modificada por esse trabalho (Santos, 1994; 2002). Dessa maneira, o espaço geográfico se caracteriza pelo trabalho humano materializado na superfície da Terra e em sua órbita ${ }^{4}$. Temo-lo como a união do trabalho morto, realizado no passado histórico (por todos os processos de produção precedentes, incluindo as antigas organizações do atual) com o trabalho vivo, esse último realizado no presente período histórico (pela específica organização do processo de produção vigente). Dessa forma, o espaço geográfico é perceptível no cotidiano como um conjunto de sistemas de objetos $^{5}$ e sistemas de ações ${ }^{6}$ (Santos, 1994; 2002).

Na materialização de seu trabalho no espaço geográfico, a humanidade sempre desenvolveu técnicas facilitadoras para a execução de seus objetivos.

"Técnicas agrícolas, industriais, comerciais, culturais, políticas, de difusão da informação, dos transportes, das comunicações, da distribuição, etc; técnicas aparentes ou não em uma paisagem, são uns dos dados explicativos do espaço geográfico" (SANTOS, 1994, p. 61).

\footnotetext{
${ }^{4}$ No caso dos fluxos aéreos de aviões, satélites e naves que agregam a informação mediata como um novo pilar técnico essencial à reprodução do capital no atual processo de globalização (Castillo, 1999)

${ }^{5}$ Sistemas de objetos são infra-estruturas materializadas na superfície da terra e em sua órbita pelo trabalho humano. Casas, móveis, ruas, avenidas, carros, escolas, prédios, parques, zoológicos, estradas, pontes, viadutos, indústrias, pastos, plantações, máquinas plantadeiras e colheitadeiras, aviões e satélites são alguns poucos objetos formadores e constituintes do sistema geográfico.

${ }^{6}$ Sistemas de ações são os fluxos que dão vida aos sistemas de objetos. Disso, compreende-se a impossibilidade de analisar os objetos e as ações isolados uns dos outros. Esses fluxos são impulsionados por intencionalidades humanas, sendo os principais os fluxos de informações, normas, pessoas, capitais e mercadorias (Santos, 2002).
} 
Tendo a técnica como instrumento intermediário das relações entre os seres humanos em si e os seres humanos e a natureza, no começo da história se imagina que havia técnicas na mesma proporção que agrupamentos humanos ${ }^{7}$. Com a passagem do tempo, as relações entre os grupos possibilitaram a expansão de técnicas dominantes e a extinção (ou limitação) de técnicas “menos eficientes”. No presente período, denominado de período técnico-científico-informacional, com a expansão das empresas centrais do sistema capitalista a todos continentes do mundo, prenuncia-se com o atual processo de globalização, a unicidade das técnicas, em cada setor das atividades produtivas, em contexto mundial. Dessa maneira, sendo a Geografia a ciência que analisa a objetividade das relações sociais no espaço geográfico, vemos a técnica como o melhor instrumento analítico dessa relação (Santos, 1994; 2002). Os sistemas técnicos transportam uma história, cada uma representando uma época. Em nossa época, o que é representativo do sistema de técnicas atuais é a técnica da informação, por meio da cibernética, da eletrônica. A técnica da informação vai permitir que as diversas técnicas existentes passem a se comunicar entre si. Ela passa a ter um papel determinante sobre o uso do tempo, permitindo em todos os lugares a convergência dos momentos e a simultaneidade das ações (Santos, 2000). Assim, os territórios do mundo passam a se informatizar muito depressa, no uso de um mesmo sistema de técnicas. Os objetos criados pelos seres humanos passam a se informatizar, estando ligados simultaneamente a qualquer outro similar na face da Terra. Esses objetos tendem a ser os mesmos em toda parte, formando sistemas de objetos hegemônicos, surgidos para atender as necessidades das ações hegemônicas.

Nos dias de hoje, o espaço se redefine como um conjunto indissociável no qual os sistemas de objetos são cada vez mais artificiais e os sistemas de ações são, cada vez mais, tendentes a fins estranhos ao lugar. (Santos, 1994; 2002). Seguindo essa concepção, compreende-se que o lugar ou a região não é parte e o mundo o todo. A região não é um fragmento, é a própria totalidade em movimento que, através dos eventos, se afirma e se

\footnotetext{
${ }^{7}$ Contudo se constata que agrupamentos que nunca tinham tido contatos entre si desenvolveram técnicas parecidas nos tempos primórdios da história da humanidade (Santos \& Silveira, 2001).
} 
nega, caracterizando um subespaço do espaço global. A região é o outro da totalidade, transformando-se numa totalidade parcial, estando ligado às outras totalidades parciais, via totalidade global (SILVEIRA, 1997). A totalidade se funcionaliza no evento. Essa função é, de início, limitada num lugar, no qual o evento se materializa. Mas, em seqüência, o lugar fica total, porque na essência - e não na sua aparência - ele tem as conexões via totalidade com todos os outros lugares: "consideramos que no lugar o todo se nega mas também se afirma cada vez mais, porque o lugar não é uma parte, é o todo mesmo concretado no local” (SILVEIRA, 1997, p. 205). Os lugares se tornam mundiais, ainda que cada vez mais diferentes entre eles, e formam uma totalidade concreta, empírica. As funções dos lugares vão empiricizando a trama dos eventos que é a totalidade (Santos, 2002). Assim, a definição do papel que a região e cidade pólo (cidade média) estabelece enquanto totalidade parcial do mundo em movimento deve respeitar muito mais os critérios qualitativos e relacionais dados na sua situação funcional dentro da divisão territorial do trabalho do que as proporcionalidades engessadas dos elementos estatísticos (Sposito, 2001).

Assim, diante da ampliação da divisão internacional do trabalho do sistema capitalista, regiões e localidades mudam suas tessituras periodicamente, anexando em seus espaços geográficos conteúdos técnicos renovados por capitais forâneos sob a tutela da elite rentista regional. Nessas reconfigurações cada vez mais globalizadas, a administração política do território vivido pelas populações regionais que constroem com suas mãos a geografia de seus lugares escapa de suas próprias decisões. 
Sobre essa realidade, Milton Santos (2002) retrata que,

“(...) A parcela técnica da produção permite que as cidades locais ou regionais tenham um certo comando sobre a porção de território que as rodeia, onde se realiza o trabalho a que presidem; (..). exercem esse comando técnico, ligado ao que, na divisão territorial do trabalho, deve-se à produção propriamente dita. Este comando se baseia na configuração técnica do território, em sua densidade técnica e, também, de alguma forma, na sua densidade funcional a que podemos igualmente chamar densidade informacional. Já o controle distante, localmente realizado sobre a parcela política da produção, é feito por cidades mundiais e os seus relés nos territórios diversos. Cidades distantes, colocadas em posições superiores no sistema urbano (sobretudo as cidades globais), têm o comando político, mediante ordens, disposição da mais-valia, controle do movimento, tudo isso que guia a circulação, a distribuição e a regulação" (SANTOS, 2002, p. 271- 273).

Seguindo esses paradigmas, nossa pesquisa tem como objetivo desvendar as funcionalidades da Região de Araçatuba e a ligação que ela passou a apreender e realizar junto ao país e ao mundo, partindo de uma abordagem histórico-espacial. Pretendemos compreender alguns dos elos produtivos (econômicos) e políticos que a porção territorial estudada, enquanto totalidade parcial manteve e mantêm com outras totalidades parciais via Totalidade Mundo durante o processo de sua ocupação. Como Araçatuba e seu entorno se adequaram e se adequam à integração funcional e territorial das redes dos circuitos produtivos globalizados de produção que se implantaram em seu espaço geográfico - café, algodão, pecuária de corte e cana-de-açúcar -, tornando-o, nos momentos de sua formação sócioespacial, especializado na realização de parte do processo de suas cadeias produtivas. 


\section{c) Apresentação da pesquisa}

Além da introdução, onde explanamos a área de estudo dessa pesquisa, seus objetivos e sua fundamentação teórica, construímos nosso trabalho em cinco fragmentos. No capítulo 1, apresentamos o processo que se desencadeou para a ocupação das terras que constituíram a atual região de Araçatuba, desde meados do século XIX a 1930, ocasionada pela expansão no território paulista da lógica capitalista de gestão e uso do território por atores nacionais e internacionais do setor cafeeiro. O extermínio dos autóctones indígenas caingangues, a anexação da ferrovia Noroeste do Brasil, a formação dos primeiros núcleos urbanos e as relações produtivas foram as ações retratadas na tentativa de compreender a constituição de uma realidade sócio-espacial à serviço de interesses externos à delimitação regional. No capítulo 2, discorremos sobre a introdução dos novos conteúdos implementados pelo setor algodoeiro entre 1930 e 1945, na porção territorial estudada. O surgimento de uma economia diversificada, o crescimento demográfico e a industrialização direcionada por atores forâneos são os principais acontecimentos vislumbrados nesse momento do trabalho. No capítulo 3, a hegemonização da pecuária bovina de corte sobre o uso das terras regionais ocorrida em meados do século $\mathrm{XX}$ e algumas implicações sócio-espaciais - como o esvaziamento populacional, o êxodo rural e a urbanização - foram as ações destacadas no intervalo entre 1950 e 1970. No capítulo 4, demonstramos alguns reflexos advindos da modernização técnico-científica subsidiada pelo Estado tanto com as inovações no circuito pecuário na década de 1970 quanto com a anexação de novos objetos e ações instalados pelo Programa Nacional do Álcool (Proálcool) no espaço geográfico regional na década de 1980. No capítulo 5, diante de um momento de desregulamentação liberal na economia a partir dos anos 1990, apresentamos a atual expansão da cultura da cana-de-açúcar nas terras da região de Araçatuba e algumas implicações na atividade da pecuária bovina de corte e sócio-espaciais acarretadas, como o dinamismo econômico (citando alguns empreendimentos infra-estruturais) e o crescimento demográfico fruto da migração gerada pelo aumento da demanda de mão-de-obra. 


\section{Capítulo 1}

\section{Do Extermínio dos Indígenas Caingangues}

\section{à Ocupação da Cultura Cafeeira}

Em nossa pesquisa buscaremos desvendar o processo de mudanças históricas na composição das culturas agropecuárias na região de Araçatuba e algumas implicações sócio-espaciais decorrentes das transformações acontecidas. Em um primeiro momento do trabalho introduziremos a história da ocupação do espaço geográfico regional a partir das imposições realizadas pelas forças políticas e econômicas hegemônicas vigorantes no momento da anexação desse fragmento do espaço paulista pelo circuito espacial cafeeiro no começo do século XX.

\section{1) Os Indígenas Caingangues}

Antes dessas ocupações, ou seja, antes da expansão da lógica capitalista de propriedade, uso e gestão das terras localizadas no Oeste Paulista, eram os indígenas caingangues que viviam e dominavam essa porção territorial. Até o início do século XX, em uma relação de equilíbrio com a natureza, os caingangues não desenvolviam mudanças acentuadas em suas terras. Esse processo de territorialidade significou que eles não construíram objetos-próteses no que hoje é a região de Araçatuba. 


\section{Foto 1: Caingangues em Canoa no Início do Século XX}

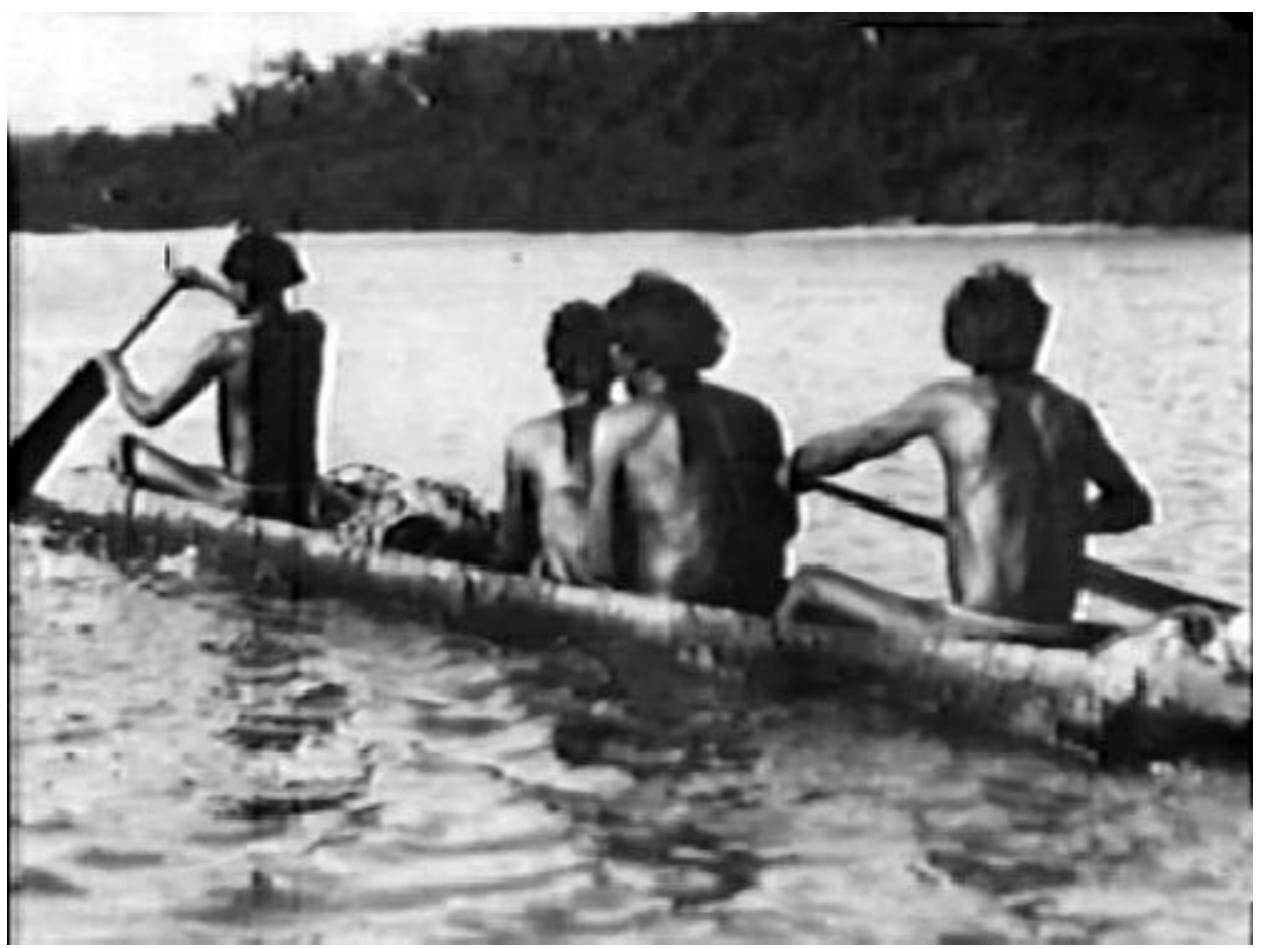

Fonte: Câmara Municipal de Araçatuba (sem data).

Embasados por Santos \& Silveira (2001), entendemos que o que se constituiu foi:

“... a imposição à natureza de um primeiro esboço de presença técnica, pois ritmos e regras humanas buscavam sobrepor-se às leis naturais. Todavia a natureza comandava, direta ou indiretamente, as ações humanas. A precariedade ou a pobreza das técnicas disponíveis constituía o corpo do homem como principal agente de transformação tanto na produção como no enfrentamento das distâncias, e ainda aqui a natureza triunfa e o homem se adapta. Era um período de acomodação e morosidade na relação com o meio, pois permitia-se que a floresta voltasse a crescer durante algumas décadas, antes do plantio recomeçar num mesmo lugar" (SANTOS \& SILVEIRA, 2001, p. 29). 


\section{Foto 2: Planalto Ocidental Paulista na Região de Araçatuba antes da}

\section{Expansão do Modo de Produção Capitalista}

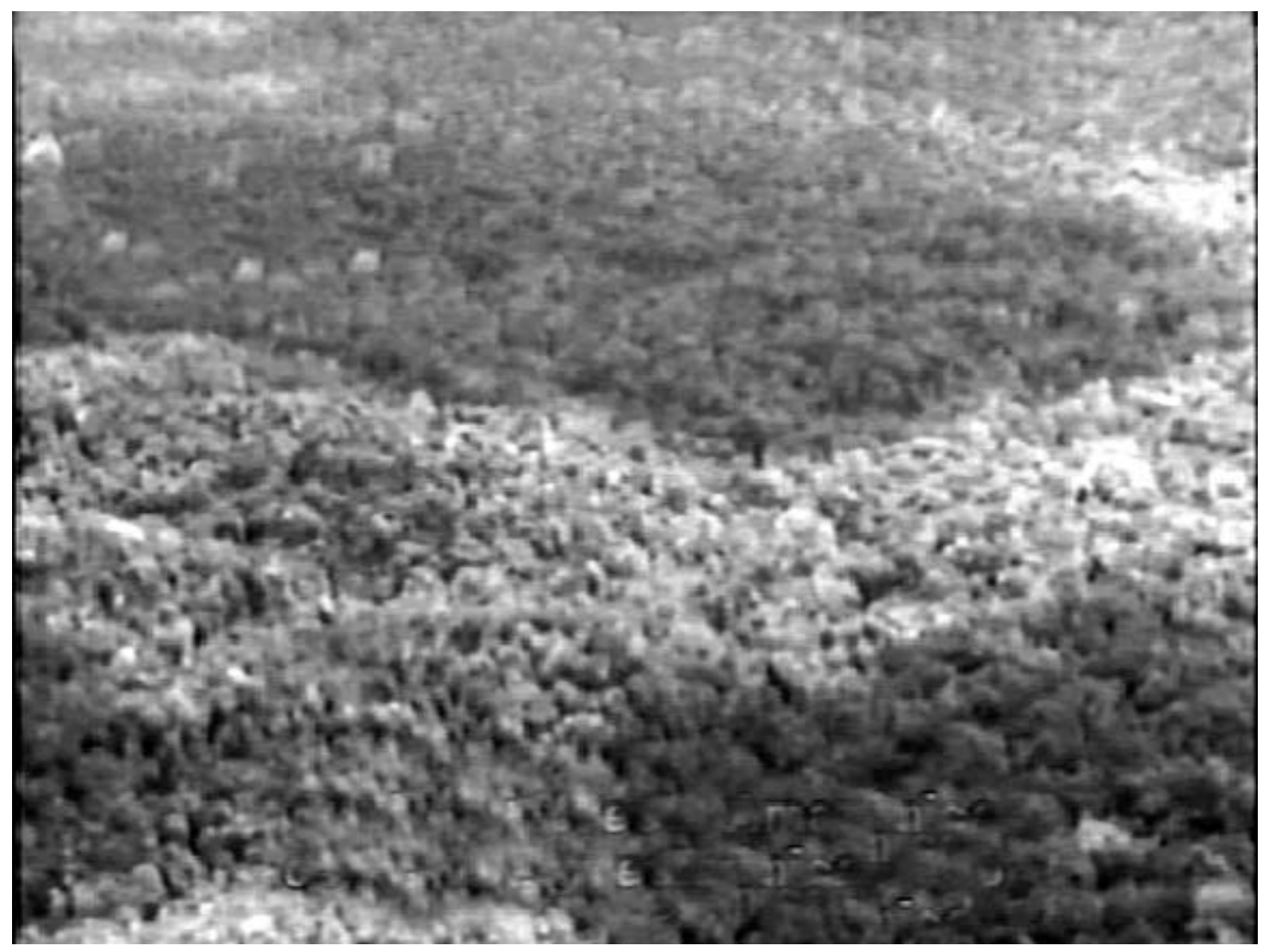

Fonte: Câmara Municipal de Araçatuba (sem data).

Desde antes da chegada dos portugueses até o início do século XX, os caingangues mantiveram seus domínios no que hoje é o extremo oeste paulista. No século XVI, segundo Sérgio Buarque de Holanda (1994),

\footnotetext{
“A permanência de caminhos numerosos que da vila de São Paulo conduziam, ora às minas gerais, ora ao sul, onde se estabeleceriam as primeiras reduções de guaranis, parece ter fixado, muito mais do que o rio Tietê, as direções iniciais da expansão bandeirante. $O$ valor dos rios estava, aparentemente, menos em servirem de vias de comunicação do que de meios de orientação" (HOLANDA, 1994, p. 34).
} 


\section{Foto 3: Rio na Hinterlândia de Araçatuba Registrado}

no Início do Século XX

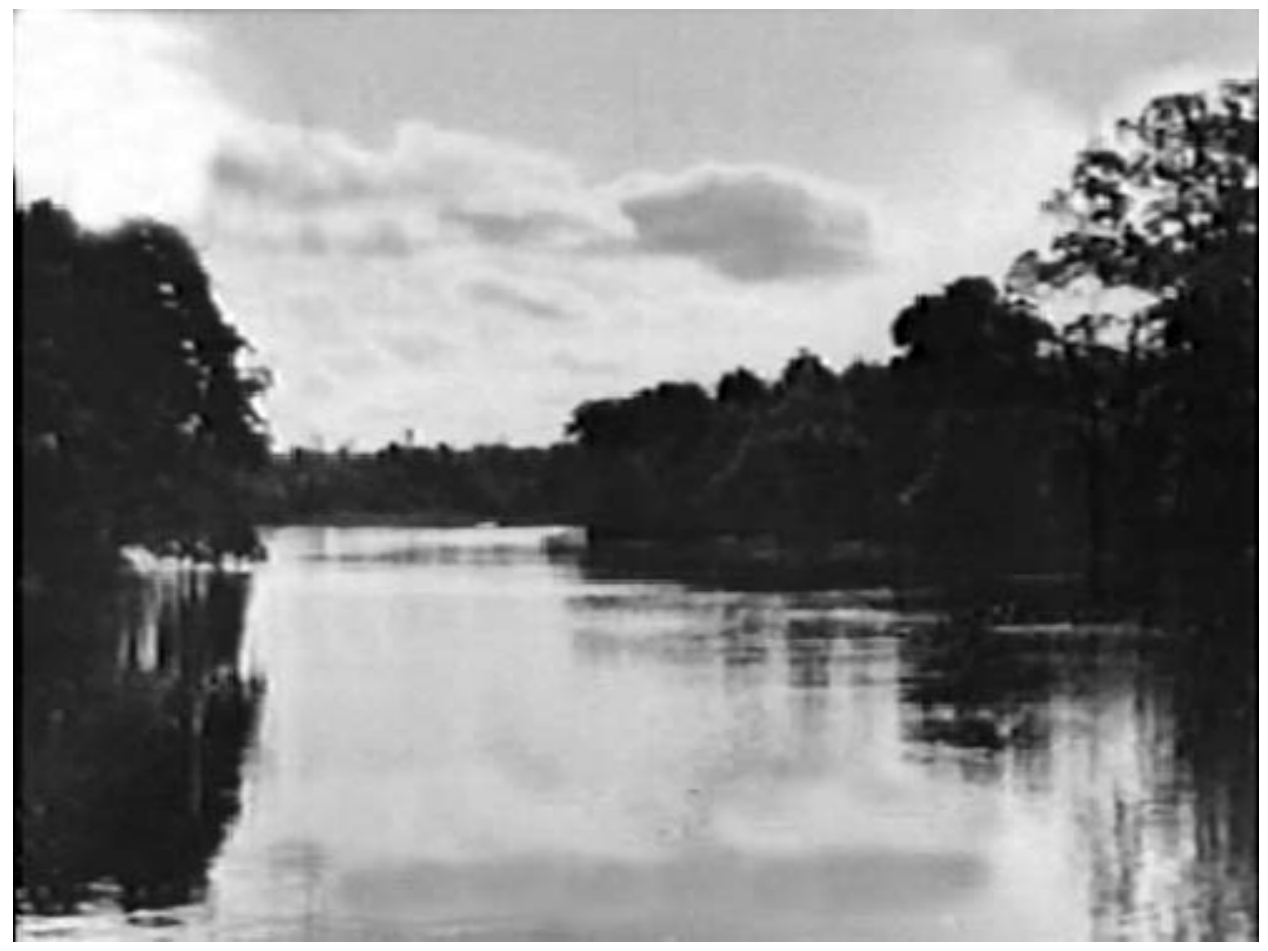

Fonte: Câmara Municipal de Araçatuba (sem data).

Já no século XVII, com a especulação de haver ouro no Mato Grosso, o Tietê se tornou rota de travessia. Nesse contato com os paulistas, os caingangues resistiram às bandeiras (monções) e às tentativas oficiais de colônias militares, como as de Avanhadava e Itapura no Tietê. O baixo Tietê apresentava índice de alta insalubridade e mais de uma vez correntes povoadoras tiveram de recuar em suas tentativas de se estabelecerem em tais áreas. 
Foto 4: Desbravadores em Incursão

\section{Financiada pela Elite Cafeicultora Paulista}

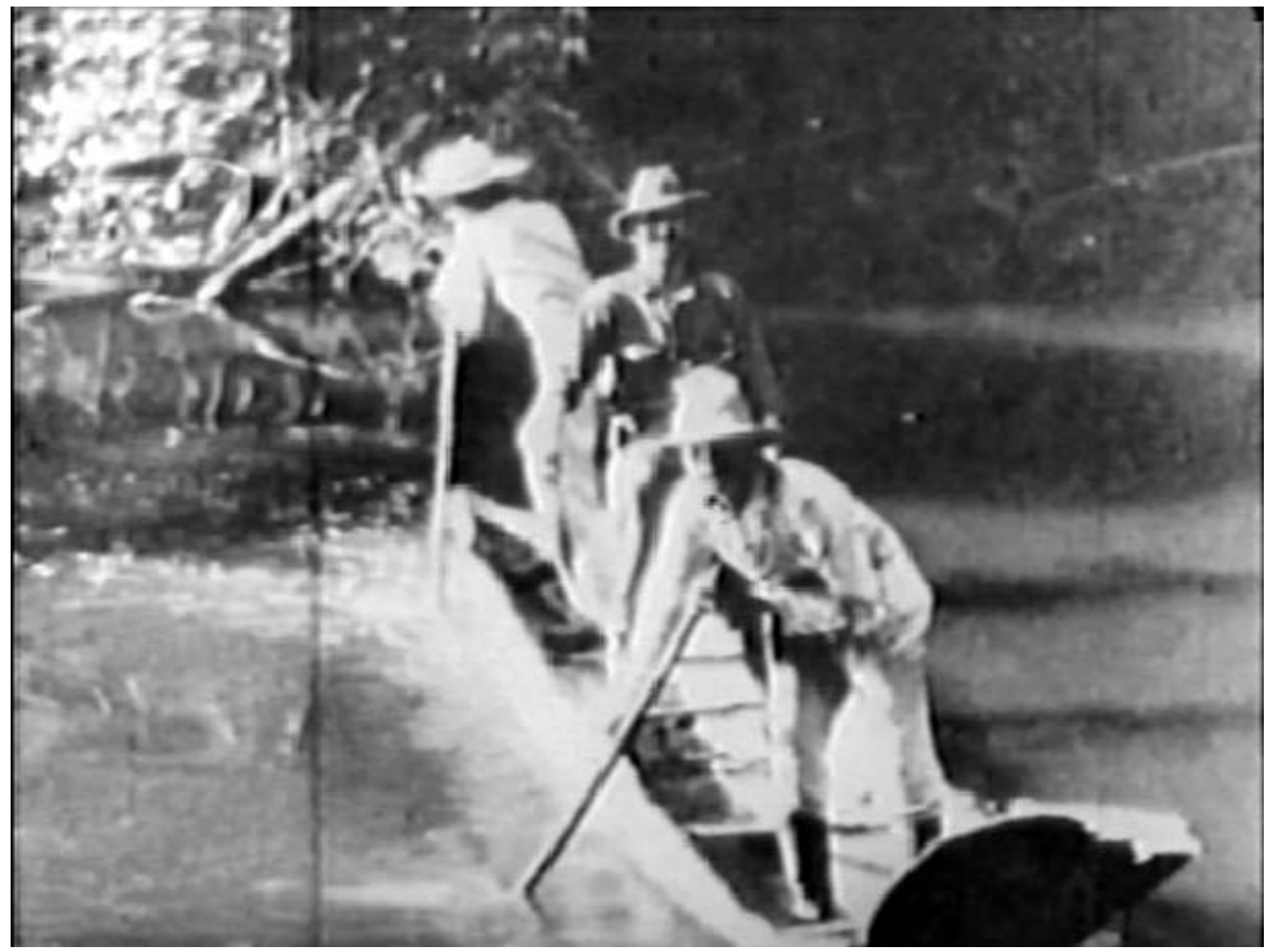

Fonte: Câmara Municipal de Araçatuba (sem data).

Segundo Mussolini (1946), os caingangues

“... não pertenciam aos grupos dos guaranis e habitavam principalmente os estados de São Paulo, Paraná, Santa Catarina e Rio Grande do Sul (...) Tratam-se de hábeis caçadores e também eram nômades” (MUSSOLINI, 1946, p. 24) ${ }^{8}$.

\footnotetext{
${ }^{8}$ Manfredi Neto, 1995.
} 


\section{Foto 5: Indígena Caingangue Realizando “Picada” dentro da Mata}

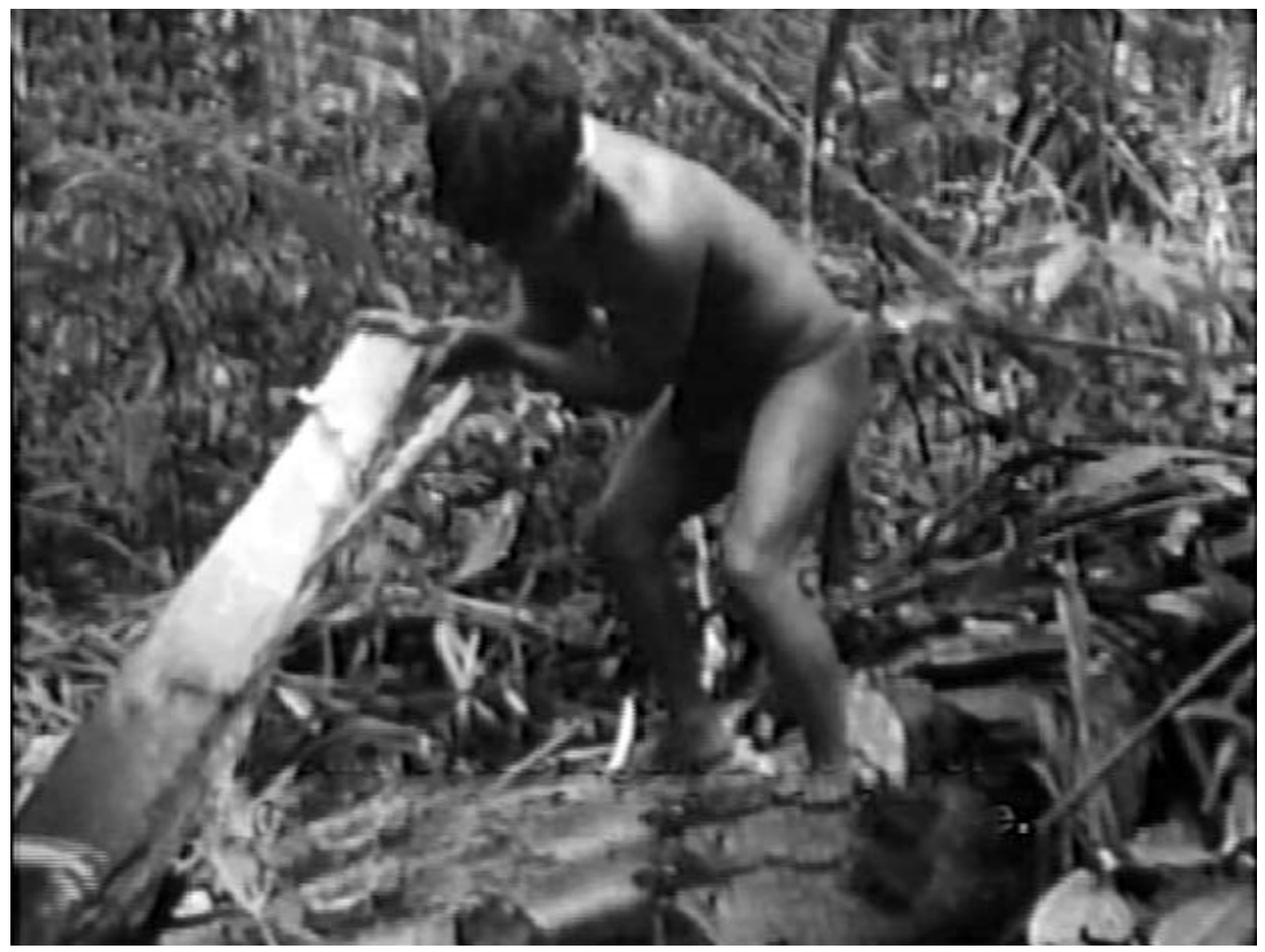

Fonte: Câmara Municipal de Araçatuba (sem data).

Manfredi Neto (1995) diz que

“... habitavam em cabanas cobertas de folhas de palmeiras, nunca fazendo divisões internas. (...) Criavam galinhas, domesticavam animais silvestres, tendo o cão como predileto. Viviam sem armamento sofisticado, com grandes arcos de pontas freqüentemente revestidos de ferro; colhiam o mel selvagem, cortavam palmito cuja medula consumiam, utilizavam fibras vegetais para tecer e fabricar cestas; as culturas de feijão, abóbora e milho eram as mais comuns: sua cultura era feita em terrenos incendiados e não se sabe quanto tempo permaneciam em cada local, pois o nomadismo era acentuado entre eles” (MANFREDI NETO, 1995, p. 28). 


\section{Foto 6: Aldeia Caingangue no Início do Século XX}

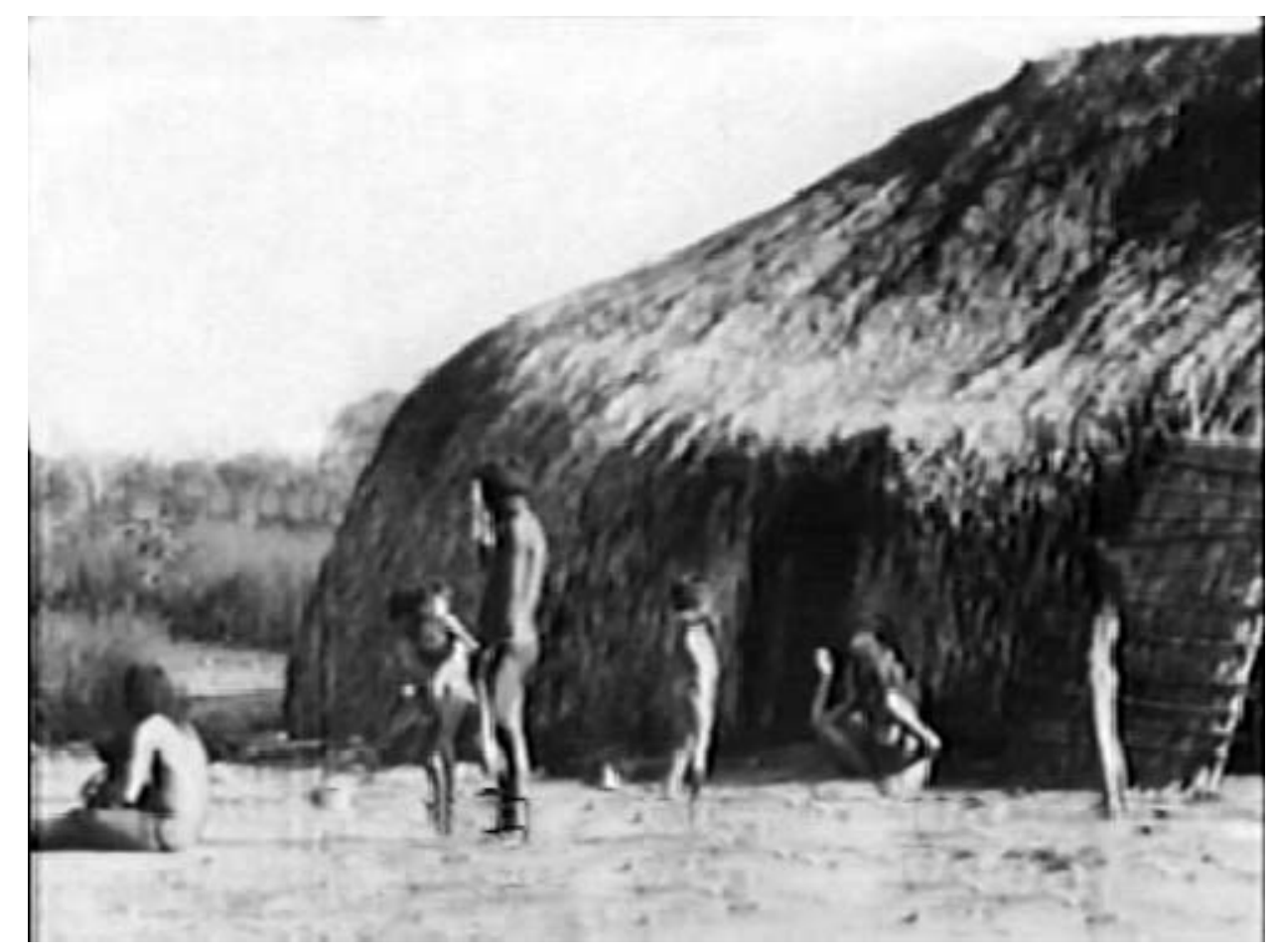

Fonte: Câmara Municipal de Araçatuba (sem data).

Mas com a expansão da lógica capitalista de propriedade da terra, essas terras indígenas foram ocupadas e os caigangues foram praticamente dizimados. Desde meados do século XIX, os conflitos com os invasores paulistas se intensificaram. Ofendidos com a ocupação de suas terras nas proximidades do atual município de Bauru, os caingangues praticaram depredações e assassinaram dezenas de pessoas (Falleiros, 1999). Devido a essa resistência, findou-se o século e os interessados na posse das terras não conseguiram adentrar e anexar o Oeste com a pretendente introdução da monocultura cafeeira. A partir de 1.901, a luta se torna mais violenta. Em 1.904, com o lançamento do decreto de concessão de construção de uma ferrovia de ligação ao Mato Grosso a partir de Bauru, a caça aos caingangues e a limpeza do futuro caminho dos trilhos se inicia de forma rápida e sanguinária. 


\section{2) A Mecanização do Espaço Geográfico Paulista e a Cultura Cafeeira}

A fixação de objetos técnicos instaladores de novas funções ao território do Oeste Paulista, está associada a um processo de transformações recorrentes às escalas estadual, nacional e mundial. Assim, a dizimação dos caingangues é parte de um desencadear de conquistas territoriais impresso pelo sistema capitalista, no Brasil, desde sua fase comercial. Dessa forma, para apreendermos o significado da instalação de um meio técnico sobre o “sertão desconhecido" paulista, analisaremos o desenrolar da formação sócio-espacial brasileira no momento da expansão da cultura cafeeira.

A criação do Brasil e a colocação descontínua em seu território de meios técnicos (mecanização do território), provêm do processo de construção do capitalismo comercial em grande escala mundial. Estabelecidos em função da demanda do mercado externo, os sucessivos meios técnicos instaurados como zonas econômicas no território nacional, percorreram os períodos manufatureiro (1620-1750), da Revolução Industrial (1750-1870) e industrial (1870-1945), como um conjunto de ‘penínsulas’ da Europa (Santos \& Silveira, 2001). Essas regiões mantinham uma relação primordial com o estrangeiro e quase nenhuma entre si. Daí o porquê de Santos \& Silveira (2001) falarem do território brasileiro nesse período como um arquipélago.

A atividade da cana-de-açúcar (Zona da Mata Nordestina), aurífera (Minas Gerais, Goiás, Mato Grosso), do cacau (Bahia), da borracha (Amazônia) e cafeeira (São Paulo), mesmo tendo criado em suas regiões famílias e gerações de cidades, não construíram entre elas nenhum tipo de integração. A ausência dessa rede nacional de comunicação e circulação caracteriza esse momento territorial ou tempo espacial brasileiro como o período da mecanização incompleta (Santos \& Silveira, 2001).

Somente por volta de 1850, preocupações referentes ao isolamento do interior brasileiro levaram o governo imperial a começar a programar um plano de conexões entre as regiões. Relacionado a esse instante, Santos \& Silveira (2001) comentam que 


\begin{abstract}
"Os portos, lugar de solidariedade entre navios, rotas de navegação e zonas produtivas, as ferrovias, as primeiras estradas de rodagem $e$ usinas de eletricidade permitiram a constituição dos primeiros sistemas de engenharia no território brasileiro" (SANTOS \& SILVEIRA, p. 33).
\end{abstract}

No que se refere ao Oeste (Mato Grosso), ocupado durante as bandeiras e monções, originou-se como grande promessa no período aurífero, mas decaiu no afastamento das culturas pastoril e da erva-mate. Influenciado de início por rotas nordestinas, a pecuária bovina matogrossense entra o século XIX grandemente direcionada ao circuito econômico argentino, paraguaio e boliviano. Sendo os caminhos “construídos” (descobertos) limitados às rotas que a natureza oferecia, o desenvolvimento pastoril encontrou na fluidez dos cursos das águas da bacia platina o melhor percurso para a comercialização de suas mercadorias. Com a convergência dessa vazante fora de nossas fronteiras,

“... fácil é concluir pela disparidade do balanço, posta em evidência, desde logo, a supremacia indiscutível e formal, da força notável que conduz para o sul, para as terras estrangeiras, numa atração fortíssima, o sistema constituído nessa zona" (SODRÉ, 1990, p. 146).

Enquanto no Brasil as ferrovias estavam limitadas há alguns trechos isolados no litoral e uma rede nacional dessas estradas não passava de estudos, a Argentina começava a construir a sua rede ferroviária (1857), principalmente direcionada ao norte do país, em "simultaneidade com a difusão das estradas de ferro em países como a Inglaterra (1825), França (1841) e Estados Unidos (1869)” (SILVEIRA, 1999, p. 48). Isso potencializou a influência externa sobre o território mato-grossense, acelerando o impasse sobre a hegemonia dos fluxos (fluviais e ferroviários) dessa região brasileira, fazendo eclodir a Guerra do Paraguai.

Após a vitória no conflito - década de 1870 -, intermediado pelos interesses econômicos britânicos, o governo brasileiro, em aliança com a elite cafeeira paulista, inicia a implementação do projeto integrativo entre a província de São Paulo, Minas Gerais, Mato Grosso e alguns países da 
América do Sul (Paraguai e Bolívia) ${ }^{9}$. É nesse contexto de integrações regionais e da expansão da demanda por terras para o plantio do café que acontece a invasão - mecanização - das áreas sob domínio caingangue na atual região de Araçatuba.

\subsection{1) O Café, a Ferrovia e seus Atores Hegemônicos}

A industrialização nos países centrais do capitalismo e a modernização dos transportes (com navios e locomotivas movidos a vapor) permitiram (impuseram) uma aceleração no comércio à distância entre as regiões do mundo. Pelo advento da Inglaterra como potência mundial, uma nova geografia de relações se instaura no processo produtivo, de circulação, distribuição e consumo da sociedade mundial. Sua urbanização iniciada nesse período muda os conteúdos da divisão territorial do trabalho: o rápido desenvolvimento de sua indústria exige, ao mesmo tempo, novos mercados aos seus produtos e novos territórios para a produção de matérias-primas e alimentos necessários ao funcionamento desse sistema.

No ambiente dessas transformações, o ingresso do Brasil, e da província de São Paulo especificamente no mercado mundial do café, é acelerado. Essa cultura, desde o primeiro quartel do século XIX, colocavase em avanço no espaço geográfico paulista. Primeiramente no Vale do Paraíba, ela se estende para a Depressão Periférica Paulista (CampinasJundiaí), principal região produtora durante a segunda metade dos anos 1800. Seu avanço ao oeste rumo a uma ocupação do planalto paulista tinha

\footnotetext{
${ }^{9}$ Falando sobre o projeto de construção da Estrada de Ferro Noroeste do Brasil, retratou Nelson Werneck Sodré que "A necessidade, vislumbrada pela clarividência de Rio Branco, da ligação ferroviária com a Bolívia, cortando as terras do Oeste, devia contribuir para a abertura e realização, embora retardada, de uma obra singular, que constituiria uma nova componente na geografia humana do Oeste, a estrada de ferro que, partindo de Bauru, no Estado de São Paulo e transpondo o vale do Paraná, chegou à barranca do Paraguai, devendo prolongar-se, através do vale deste último, rumo Corumbá, para atingir, com a parte boliviana, a cidade de Santa Cruz de la Sierra” (SODRÉ, 1990, p. 111). Mais adiante em seu texto, o mesmo autor diz: "A via férrea estabeleceria o elo imprescindível, articulando a região do Oeste ao corpo nacional. Quebraria o perigoso divórcio que vinha na tradição histórica, imposto pelas eventualidades, imperativas da configuração geral da geografia americana. Aproximando a região pastoril do mercado consumidor constituído em São Paulo, pelo adensamento de população que a lavoura cafeeira aí proporcionara e fornecendo o transporte, em troca, do parque industrial paulista ao sertão mato-grossense, dos artigos necessários à vida e ao conforto, a via férrea estabeleceria o mais forte laço de união, desde que o apoiaria na reciprocidade de interesses econômicos" (SODRÉ, 1990, p.151).
} 
limites operacionais relacionados aos custos do transporte do produto ao litoral, de onde ele era encaminhado ao mercado consumidor internacional.

Até esse momento, a principal técnica de transporte entre o litoral e o interior, antes da construção das ferrovias, era constituída por numerosas tropas de muares e bovinos. Para a maior parte do país, o transporte em lombo de burro e puxado por bovinos atendia satisfatoriamente ao modesto volume do comércio exterior. A exceção a essa regra era a província de São Paulo, onde se produziam, no final do século XIX, excedentes exportáveis em torno de 500.000 arrobas de café que deixavam de ser vendidos ao exterior devido às deficiências de transporte. Isso correspondia a 25\% da produção (Queiroz, 1999).

\section{Foto 7: Tropa de Bovinos Transportadora de Mercadorias}

\section{na Região de Araçatuba}

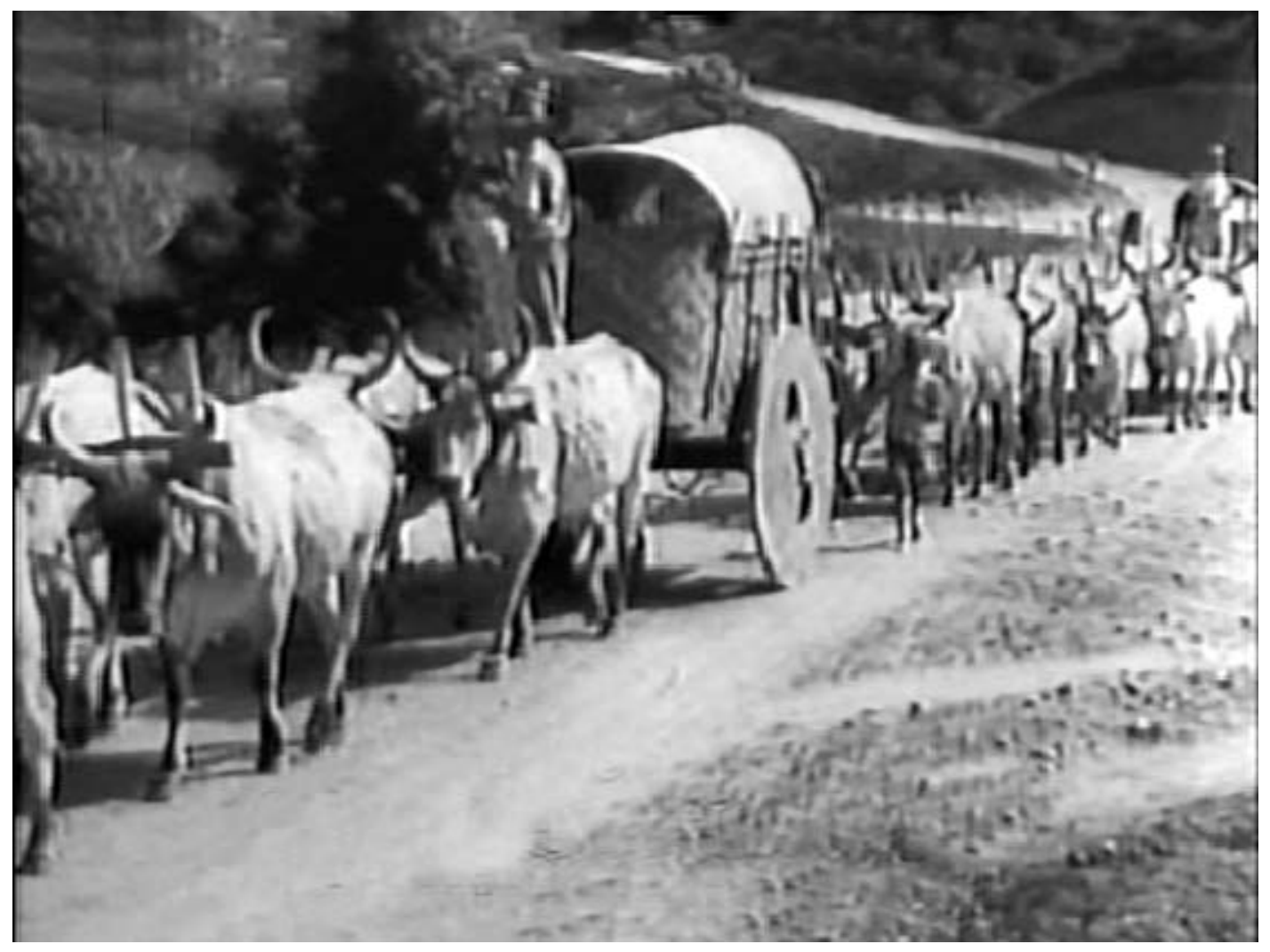

Fonte: Câmara Municipal de Araçatuba (sem data). 
Unido ao discurso geopolítico de integração de São Paulo ao Mato Grosso, para superar esse gargalo e dinamizar com a fluidez necessária a expansão do circuito espacial de produção do café, surgiu o projeto de construção das ferrovias em direção ao Oeste. 


\subsection{2) A Formatação da Espacialidade Capitalista na Província de São Paulo e na Região de Araçatuba}

Parceria dos fazendeiros e do poder público (que eram os mesmos atores) com financiadores internacionais possibilitou fundos de capitais para a construção das estradas de ferro ${ }^{10}$. Formada "por uma sociedade de ricos fazendeiros, que tirava sua força de sua dupla origem, rural e mercantil ao mesmo tempo" (MONBEIG, 1998, p. 97), a classe dirigente paulista, enquanto atora hegemônica do processo de anexação do oeste paulista ao circuito capitalista de produção, cria as sociedades ferroviárias ao redor de 1870. Na continuidade do raciocínio, Monbeig (1998) diz que “... quando se pôs em movimento o avanço paulista (...), encabeçava-
o uma classe de grandes fazendeiros, que ao mesmo tempo dirigia
importantes sociedades bancárias e ferroviárias, bem como detinha
postos na administração pública (...) Até a década de 1930, foram os
grandes fazendeiros, de algum modo, os dirigentes de São Paulo.
Confundia-se o interesse coletivo com o seu interesse de classe. Esse
fato sociológico liga-se à geografia do movimento pioneiro. Os
problemas de mão-de-obra e, conseqüentemente, o povoamento, os
das vias de comunicação, os dos preços foram considerados e
tratados acima de tudo, em função dos interesses dos fazendeiros”
(MONBEIG, 1998, p. 139-140).

As famílias Toledo Piza e Almeida Prado são exemplos dados desse grupo que concentrava atuação na atividade agrícola, ferroviária, bancária e principalmente, de interlocução com o capital internacional financiador da ocupação do oeste paulista (Monbeig, 1998). São essas sociedades, que na anexação de novas áreas requeridas ao abastecimento do centro do sistema, mecanizaram o espaço geográfico paulista mediante a instalação dos objetos-próteses que são as ferrovias e a cadeia produtiva do café. Uma nova geografia dos fluxos significou a penetração e o conhecimento mais acelerados do interior, voltados aos interesses estrangeiros. A formatação dessa geografia é o que veremos mais adiante.

\footnotetext{
${ }^{10}$ Para Prado Jr. (1948), o fim do tráfico negreiro possibilitou uma inversão de capitais dessa atividade para outros setores; permitiu também a normalização das relações com a Grã-Bretanhã, gerando um grande aumento dos fluxos de capitais dessa e de suas nações parceiras ao Brasil.
} 


\subsection{3) As Ferrovias no Espaço Geográfico Paulista}

A década de 1870 foi um divisor de águas na modernização do espaço geográfico paulista. É nesse momento histórico que se criaram as possibilidades para que esse fragmento do território nacional se tornasse palco dos imperativos da divisão internacional do trabalho, começando a receber inovações garantidoras desse pertencimento.

Assim, as sociedades ferroviárias, São Paulo Railway Company, Companhias Sorocabana, Mogiana e Noroeste do Brasil, ligando lugares antes isolados entre si, surgiram dando fluidez às ações no espaço geográfico, como máquinas sugadoras de café das regiões especializadas no produto até aos portos e ao mundo ${ }^{11}$. Retratando o histórico dessas companhias ferroviárias, aprofundando nossa análise na Noroeste do Brasil $^{12}$, temos:

- São Paulo Railway Company: A São Paulo Railway Company (Estrada de Ferro Santos-Jundiaí), ferrovia pioneira de escoamento do café, foi construída e inaugurada em 1867 com capitais ingleses. Na expansão das áreas de cafeicultura, em 1868, um grupo de fazendeiros resolve criar a Companhia Paulista de Estradas de Ferro, ligando de início Jundiaí a Campinas e depois se prolongando até Bauru.

\footnotetext{
${ }^{11}$ Dando ênfase às contradições desse processo de mecanização do território brasileiro, Santos \& Silveira (2001), mostrando a prioridade dos interesses estrangeiros nesses trajetos da circulação mecanizada, disseram que "a busca da integração nacional não era um imperativo da construção dessas redes" (SANTOS \& SILVEIRA, 2001. p. 21).

${ }^{12}$ Ferrovia que atravessará a região onde se localiza nosso estudo de caso.
} 
- Companhia Sorocabana: A Companhia Sorocabana, iniciada em 1872, era formada por um grupo de dissidentes do consórcio que comporia a Companhia Ituana no mesmo ano. A primeira ligaria São Paulo a Ipanema, a segunda, Itu a Jundiaí. O primeiro trecho da Sorocabana, com 120 Km de extensão, foi inaugurado em julho de 1875, e três anos depois estendeu suas linhas para as cidades de Tietê, Tatuí, Itapetininga e Botucatu. As linhas da Companhia Ituana chegaram em Piracicaba em 1877, promovendo uma integração com o transporte fluvial até o porto de Lençóis. Em 1892, as duas companhias se fundiram formando a Companhia União Sorocabana, a maior rede ferroviária do estado com $820 \mathrm{Km}$ de extensão. A partir da fusão, novas linhas foram construídas, principalmente rumo ao ramal Bauru. De 1907 a 1919, depois de uma crise que a passou ao controle estatal, foi arrendada a um consórcio franco-americano, que atingiu Presidente Prudente até às margens do Paraná. Contudo, o maior feito da Sorocabana foi a quebra do monopólio da São Paulo Railway, com a ligação ao Porto de Santos via Mairinque.

- Companhia Mogiana: Em 1872, um outro grupo de fazendeiros funda a Companhia Mogiana de Estradas de Ferro, com o intuito de propiciar o escoamento do café de uma das regiões mais produtivas da província no momento, a região de Mogi-Mirim e Amparo. Nas próximas décadas a companhia estendeu seus trilhos para Minas Gerais e para a região de Ribeirão Preto, sendo esta última a de maior destaque na produção cafeeira do começo do século XX. Para essa expansão, o empréstimo de capitais ingleses foi fundamental. 


\subsection{4) Companhia Estrada de Ferro Noroeste do Brasil (C.E.F.N.O.B)}

Essa integração da elite nacional com as elites internacionais, através de parcerias nos empreendimentos da cadeia produtiva do café, confirma a anexação territorial do interior paulista pela lógica do capitalismo global. Assim, as ferrovias Santos-Jundiaí, Sorocabana, Mogiana e Noroeste do Brasil são exemplos de aberturas infra-estruturais colocadas à serviço dessa expansão territorial da cultura cafeeira ao oeste paulista.

Com Furtado (1959), obtivemos a compreensão de que o aumento da produção demandado pelo consumo no mercado internacional do café era obtido de forma extensiva, com a expansão das áreas de plantio. Assim, sendo o café o produto do momento e o oeste paulista o espaço 'vazio' - em contigüidade - mais propício ao avanço da cultura, os dirigentes políticos e econômicos trataram de resolver o principal problema surgido para a integração dessas novas áreas: ligar uma infra-estrutura de transporte possibilitadora de custos de produção factíveis ao escoamento da mercadoria ao litoral.

Dessa forma, enquanto a Paulista, a Mogiana e a Sorocabana buscaram as regiões já povoadas e com produção substancial de café, no intuito de resolver os problemas de seu escoamento ao litoral, a Noroeste do Brasil, ao ser construída, avançou por áreas quase 'despovoadas' do território do estado de São Paulo (Saes, 1981).

De capitais mistos, brasileiro e franco-belga, com concessão de garantia de juros baixos pelo governo federal, a construção da Noroeste se iniciou em 1905. Terminados os estudos para a locação da linha férrea, a Companhia de Estradas de Ferro Noroeste do Brasil e a companhia empreiteira dos serviços mandaram para Bauru os primeiros engenheiros, técnicos e operários que se encarregariam da construção. Muitos morreram de várias moléstias (como a leishmaniose e a malária) e no confronto com os índios caingangues. Em 2 de dezembro de 1908, os trilhos chegavam ao quilômetro 281, onde futuramente se fundaria a cidade de Araçatuba. 
Foto 8: Primeira Estação Ferroviária em Araçatuba

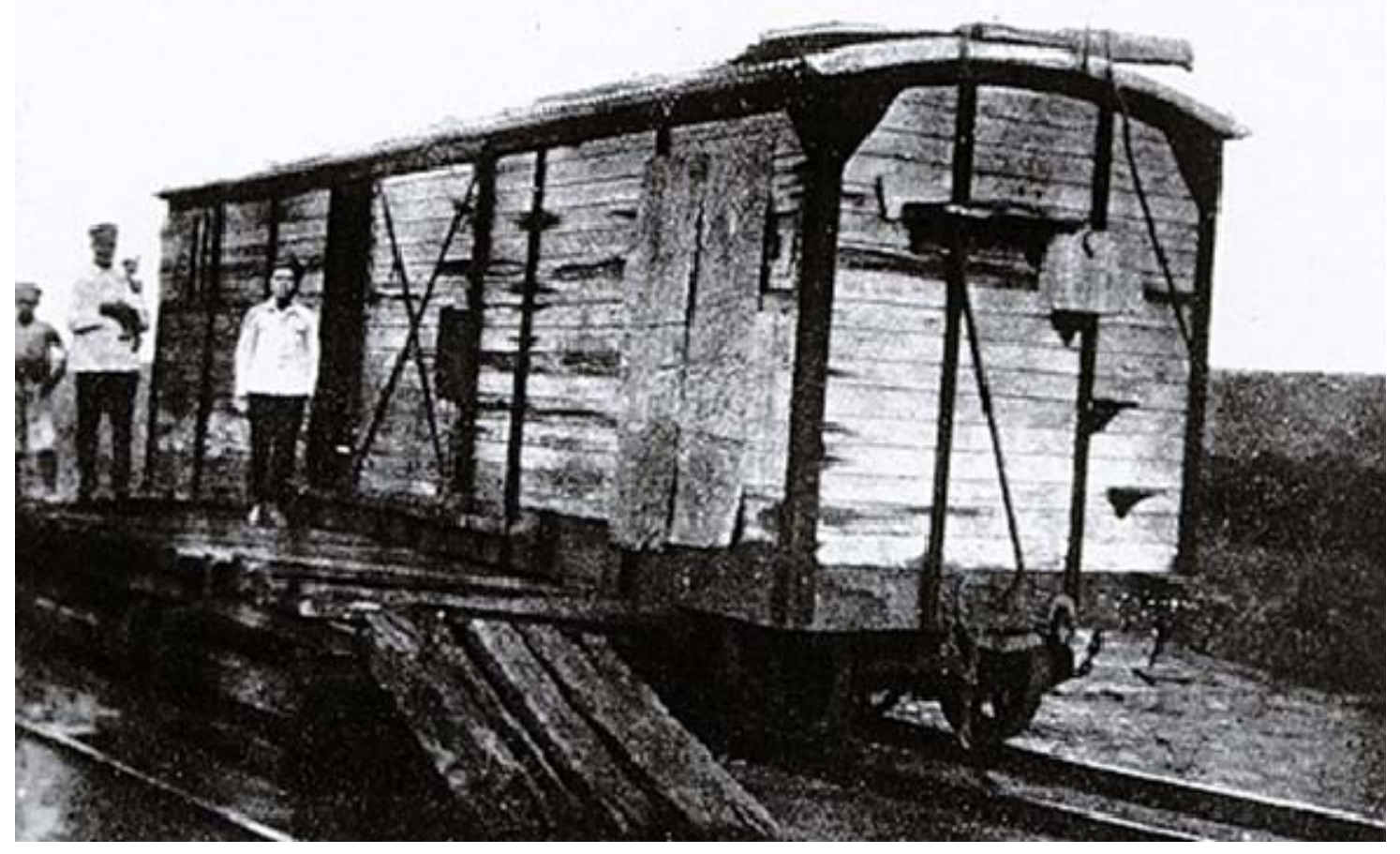

Fonte: Câmara Municipal de Araçatuba (sem data). 
Foto 9: Segunda Estação Ferroviária em Araçatuba

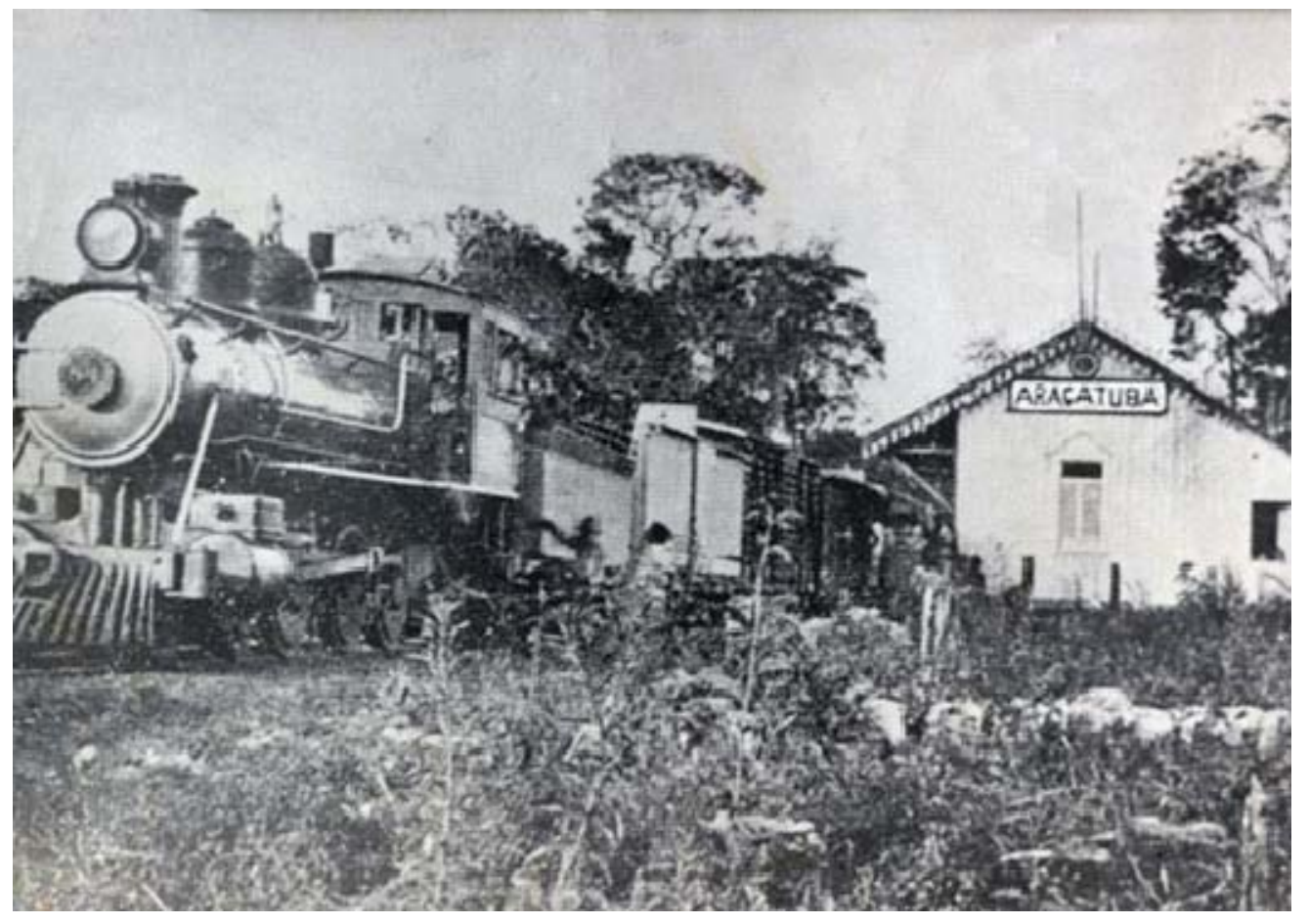

Fonte: Câmara Municipal de Araçatuba (sem data). 


\subsection{5) A Ocupação das Terras da Região de Araçatuba}

Mesmo antes das possibilidades técnicas dadas com o advento das estradas de ferro, a elite dirigente buscou alternativas oficiais de reconhecimento e anexação do oeste paulista. Mesmo pertencendo aos silvícolas caingangues, através da Lei de Terras de 1850, as terras da região foram normatizadas como devolutas; propriedade do governo imperial do Brasil.

Cavenagui (2004), em um excelente trabalho sobre o uso político da fotografia e da cartografia no espaço geográfico paulista de 1850 a 1910, mostra como, mesmo antes da ocupação, operou-se a legitimação da posse dos 'terrenos desconhecidos' no planalto paulista. São apresentadas produções cartográficas da província de São Paulo, onde os territórios indígenas são incorporados sob a administração da elite política e econômica paulista.

Tendo cada porção territorial o seu valor, o oeste paulista, mesmo inutilizado economicamente até o final do século XIX pelo sistema econômico hegemônico em expansão, através dessa cartografia citada, passa a ser colocado como uma reserva de valor a ser explorada nos anos vindouros. Para Magnoli (1996), essa produção cartográfica serviu para reforçar o caráter de devolutas das terras 'desocupadas' do Brasil e legalizadas com a Lei de Terras de $1850^{13}$.

Após a Lei de Terras, com o 'poder público' tendo o controle dessas terras 'desocupadas’ rumo a uma regularização fundiária capitalista, estas passam, em sua grande maioria, a serem vendidas às companhias de colonização, que por sua vez, as revendiam em condições muito lucrativas. Monbeig (1998), citando Delgado de Carvalho (1910), exemplifica com o caso de uma propriedade comprada por 230 contos de réis, revendida por 500 e transferida a um terceiro por 1000 contos, tudo em alguns anos.

A Lei de Terras deu um prazo de alguns anos para a legalização de propriedades, o que também incentivou posseiros a atuarem no 'sertão

\footnotetext{
${ }^{13}$ Com isso, reproduz-se ideologicamente a produção de um imaginário geográfico destinado a legitimar a efetiva ocupação da ‘civilização’ e modernidade a ocorrer no futuro.
} 
desconhecido’ de São Paulo (Cavenaghi, 2004). Com isso, a partir de 1850, devido ao declínio da produção aurífera e a obrigatoriedade do alistamento militar para a Guerra do Paraguai, muitos mineiros, encontrando possibilidades de enriquecimento, começaram a ocupar as terras do oeste paulista (Queiroz, 1999).

Antes desse período, a 'boca do sertão’ para o oeste era Botucatu. Com essa corrida pela legalização, foram registradas posses de terras e se deu o surgimento de povoações em Franca, Bauru e na região do rio Paranapanema. Muitos indígenas dessas regiões - principalmente de Bauru - se deslocaram para o extremo oeste paulista, entre os rios Aguapeí e Tietê, onde hoje se localiza Araçatuba (Ghirardello, 2000).

Até 1880, a ocupação de terras existente de Botucatu a Bauru foi subordinada à população local, onde a produção agrícola em sua maioria era destinada à subsistência. Somente o excedente - carne de porco, principalmente - era comercializado nas feiras de Lençóis Paulista, Botucatu e Sorocaba (Ghirardello, 2000). Praticando uma agricultura de roça antiquada e no limite do mercado - sendo quase a totalidade da produção direcionada para o auto-consumo -, os mineiros ocupadores das terras entre Bauru e Botucatu exerceram a função histórica de abrir os "terrenos desconhecidos” para a futura instalação das atividades capitalistas.

No final da década de 1880, o povoado de Bauru passa a crescer rapidamente devido à abertura em suas proximidades de grandes lavouras de café $^{14}$. Com o aumento da demanda desse produto no mercado internacional, os grandes cafeicultores viram no oeste paulista a opção de reverterem seu capital ${ }^{15}$ com a propriedade de terras baratas e mesmo

\footnotetext{
${ }^{14}$ Nessa década, a cidade de Bauru começa a passar por transformação administrativa importante, transpondo seu gerenciamento hegemônico, de maneira conflitiva até a década de 1910, das mãos da Igreja à uma estrutura laica representante do capital cafeeiro. Como "boca do sertão", localizada no centro da província paulista, recebe em um primeiro momento a convergência dos trilhos das Companhias Paulista e Sorocabana. Em um segundo momento, exercerá a nobre função de entreposto controlador dos fluxos estabelecidos após a construção da Companhia Noroeste do Brasil.

${ }^{15}$ Com a decadência da escravatura, a renda capitalizada dos fazendeiros deixa de se configurar na posse de escravos. É a posse da terra, e principalmente das riquezas comerciáveis nela produzidas, que passa a ser a garantia na obtenção de crédito por parte dos fazendeiros: “Em 1873, o governo estendera o crédito hipotecário a todos os municípios da província de São Paulo, Paraná e Santa Catarina, tendo como suporte a fazenda, representada sobretudo pelas plantações e pelas instalações. Esse procedimento é seguramente uma das causas da intensificação da expansão do café em direção ao oeste de São Paulo, para a região de Campinas e mais além.” (MARTINS, 1996, p.30).
} 
gratuitas (na ocupação e falsificação de posse de terras devolutas). Assim, de Bauru em direção ao extremo oeste, marginando a linha ferroviária, a ocupação das terras foi realizada de maneira diferente à ocorrida entre Botucatu e Bauru pelos mineiros. No ato de estender a fronteira de ocupação “civilizatória” à oeste, introduziu-se diretamente, sem intermediação, os tentáculos (objetos) técnicos distintivos daquele momento de modernidade do capital: a ferrovia e o circuito espacial do café. Diferente das variáveis conjugadas no gênero de vida mineiro, a produção do espaço geográfico na Noroeste Paulista impôs normatizações ao uso das terras da fronteira estendida formuladas por atores estranhos ao seu cotidiano até então configurado pela cultura, técnicas e normas caingangues.

Esse processo de anexação da Noroeste Paulista ocorreu em duas etapas distintas: de Bauru à Promissão, com um caráter mais familiar; e de Promissão à Andradina, com um estilo mais empresarial. Findando essa primeira etapa, em 27 de setembro de 1906 foi inaugurado o primeiro trecho de Bauru rumo ao extremo oeste paulista. Esse trecho já possuía uma recente ocupação rural, feita por grandes famílias da elite econômica paulista, que se adiantaram aos trilhos: os Rodrigues Alves e os Toledo Piza (Falleiros, 1999).

Como as vilas (futuras cidades) nasceram à beira das estações, as plantações surgiram às margens da estrada de ferro. Em cada estação se “nomeava” um agente imobiliário, o qual intitulavam fundador. 
Foto 10: Fachada Lateral da Terceira Estação Ferroviária de Araçatuba

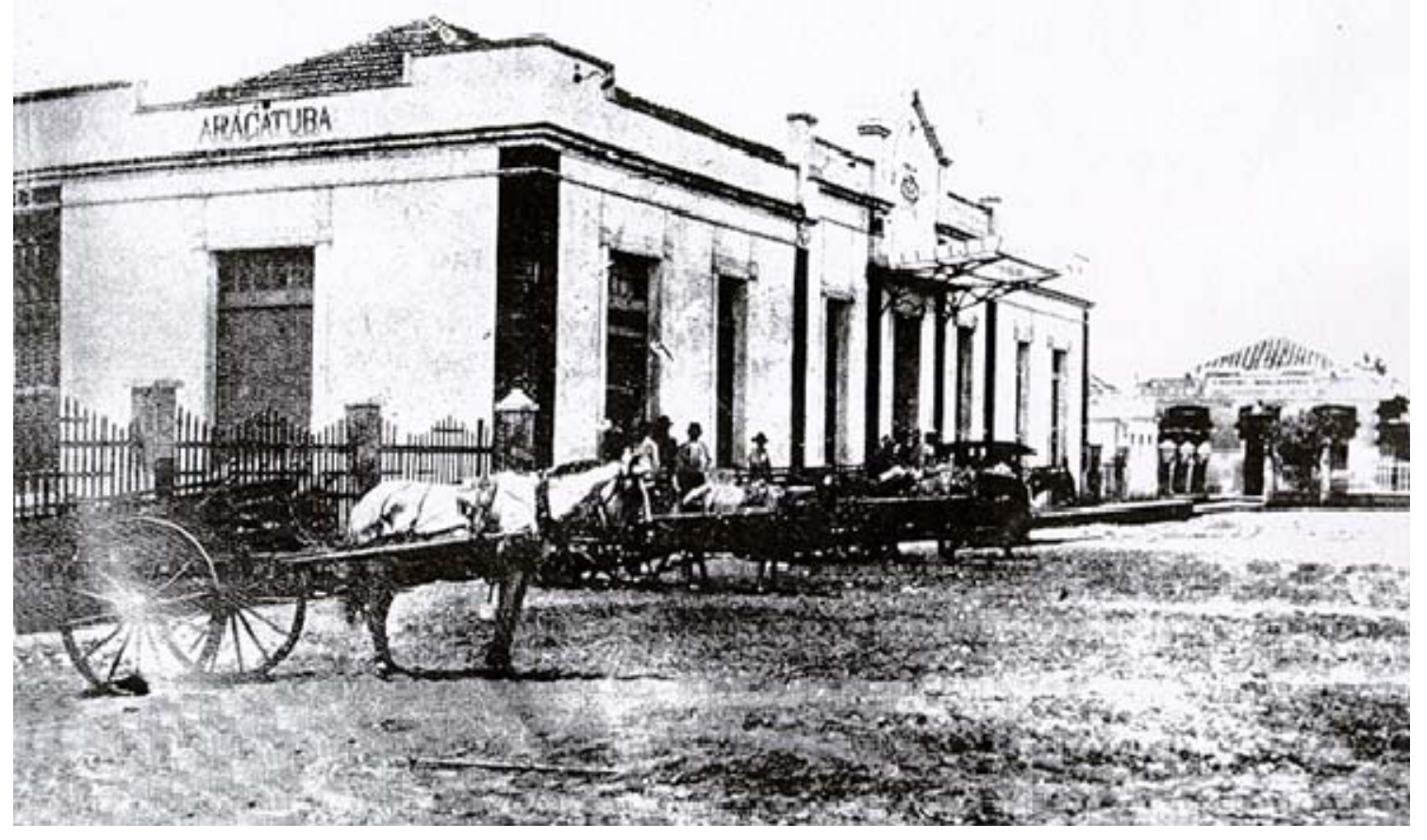

Fonte: Câmara Municipal de Araçatuba (sem data). 
À medida que a influência de novos moradores exigia, das ruas principais se prolongavam novos quarteirões junto com praças, avenidas e outros logradouros públicos (Ghirardello, 2000).

\section{Foto 11: Panorâmica da Centralidade Surgida ao Redor de Estação}

Ferroviária na Região de Araçatuba

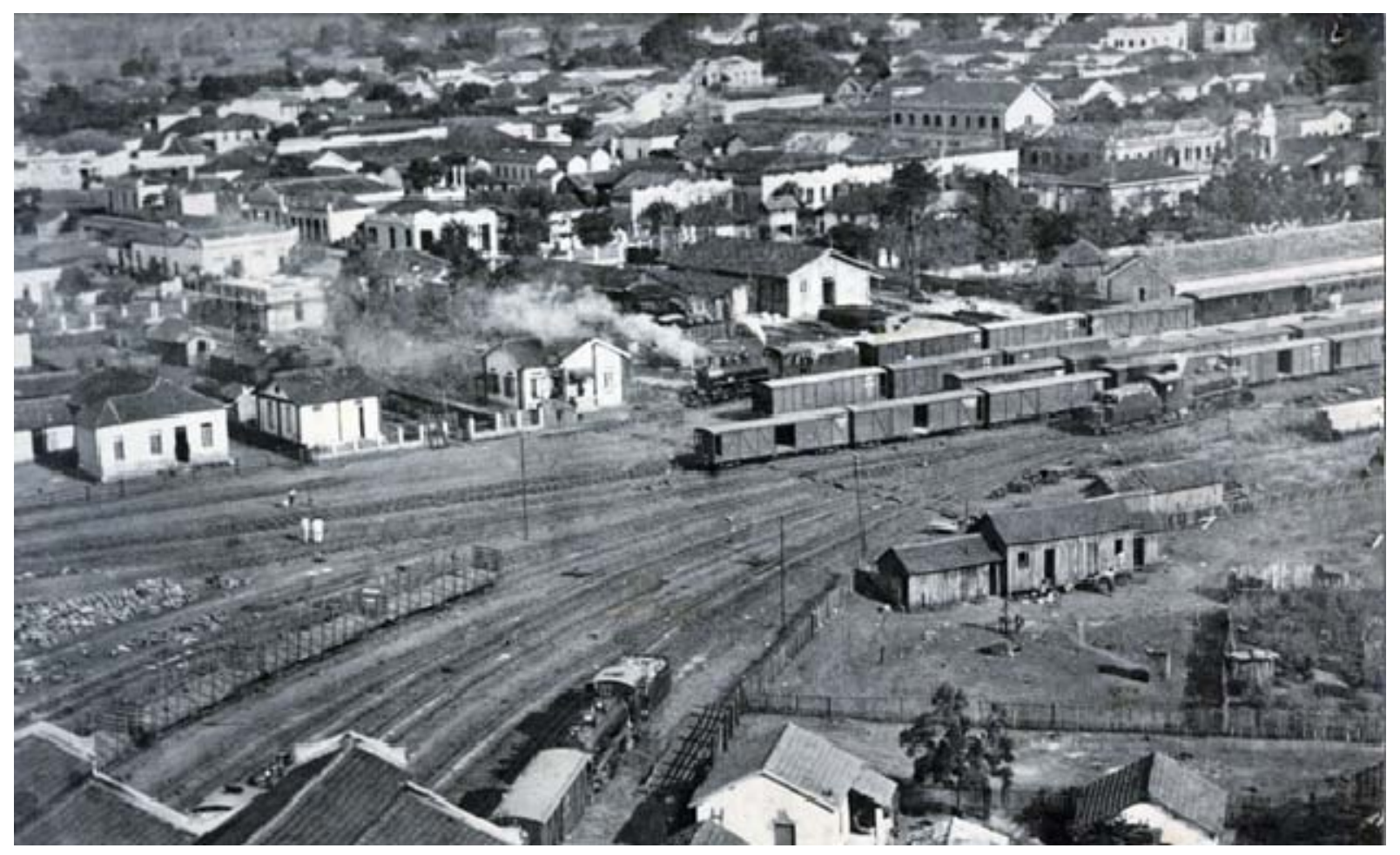

Fonte: Câmara Municipal de Araçatuba (sem data).

Era da cidade que se executavam diretamente as ordens longínquas de como deveria funcionar o gerenciamento da lavoura cafeeira. Doadas ou vendidas à Câmara Municipal da cidade de Bauru - que fora elevada no fim dessa primeira década à comarca jurisdicional abrangendo toda a Noroeste as áreas circundantes das estações de Pirajuí, Avaí e Lins surgiram como vilas, distritos de paz de Bauru. Cafelândia e Promissão foram retalhadas pelos próprios proprietários, que dividiram as terras em datas e as colocaram à venda (Ghirardello, 2000).

De Promissão à Araçatuba, a ocupação aconteceu de forma menos familiar e mais empresarial, respaldada por capitais internacionais (Martins \& Ramos, 1961). A figura do coronel Manoel Bento da Cruz no 
retalhamento do que se constituirá a Noroeste Paulista, foi de fundamental importância. Como enviado de agentes públicos e privados de São Paulo e Rio de Janeiro - capitais da província e da federação respectivamente - em 1905 já está na região que seria atravessada pela estrada de ferro.

Em um primeiro momento, Bento da Cruz, advogado, apresenta-se como defensor dos direitos de propriedade para as famílias dos antigos posseiros - mineiros - que ocuparam a região no início do século XIX nas proximidades da colônia militar de Avanhandava ${ }^{16}$.

\begin{abstract}
“(...)Longe de ser uma personalidade singular, Manoel Bento da Cruz representava bem a moral dos primeiros anos republicanos, a ética dos novos tempos (...) Dentro desses paradigmas, Manoel Bento da Cruz será como nenhum outro, na Zona Noroeste, um representante dos novos tempos de liberalismo econômico" (GHIRARDELLO, 2000, p. 78) ${ }^{17}$.
\end{abstract}

Manifestando bem o espírito da época, para introduzir as inovações do período na área, o extermínio da quase totalidade das dezenas de milhares dos resistentes índios caingangues era a próxima tarefa a se executar. Com o início da construção da estrada de ferro e a conseqüente valorização das terras, as tentativas de penetração e de apossamento se multiplicaram. Foram organizadas verdadeiras expedições de combate aos índios - sendo a carabina Winchester a principal técnica de guerra dos brancos - que não puderam resistir com suas flechas e emboscadas. Foram completamente vencidos e obrigados a aceitar em negociação intermediada pelo Serviço de Proteção ao Índio (SPI) as reservas e os aldeamentos que lhes foram oferecidos - Icatu em Braúna e Capitão Kenkrá e Vanuire em Tupã- (Falleiros, 1999).

\footnotetext{
${ }^{16}$ Mesmo sem documentação, esses poucos herdeiros que nem mais moravam na antiga colônia (moravam nas proximidades de São José do Rio Preto e Bauru) - pois foram expulsos pelos índios caingangues - podiam ser considerados legalmente como donos das terras da região. Nessa transação, quando Cruz descobriu as posses daquela gente, foi de casa em casa tomando procuração de todos para levantamento e legislação das terras apossadas, recebendo a metade delas em pagamento. Ghirardello (2000) relata que: "Dessa maneira Bento da Cruz consegue amealhar uma quantidade de terra estimada em 30 mil alqueires, em boa parte acompanhando a linha da C.E.F.N.O.B.” (GHIRARDELLO, 2000, p. 78).

${ }^{17}$ Para reforçar o momento histórico adentrado pelo país, GHIRARDELLO (2000, p. 78) cita PRADO JR: "nenhum dos freios que a moral e a convenção do império antepunham ao espírito especulativo e de negócios subsistirá; a ambição do lucro e do enriquecimento consagrar-se-á como um alto valor social” (PRADO JR., 1994, p.208).
} 


\section{Foto 12: Contato Negociador dos Índios Caingangues com Representante do Capital Cafeeiro}

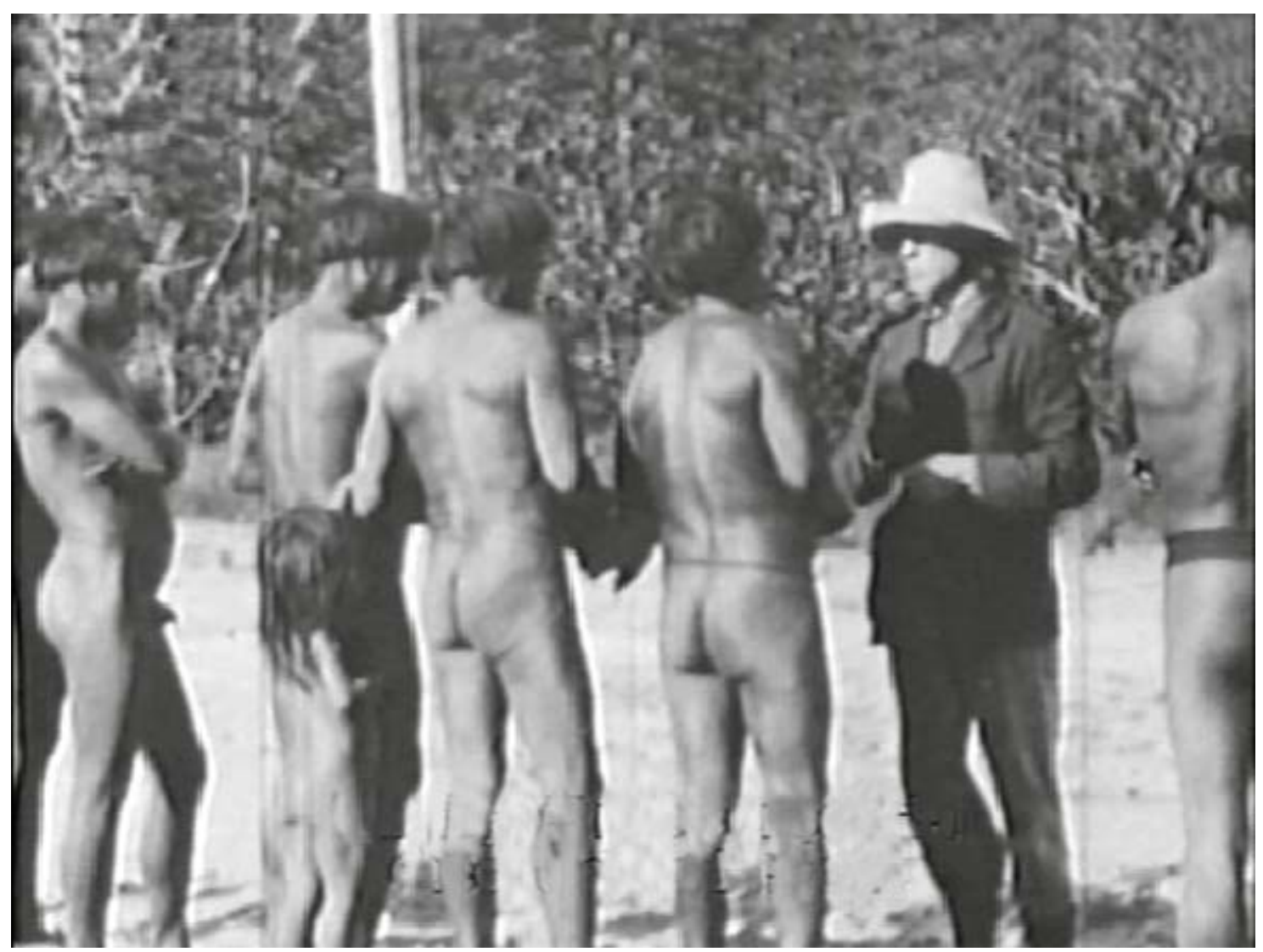

Fonte: Câmara Municipal de Araçatuba (sem data).

O fim do conflito e da carnificina em 1912 representou a liberdade da franca ocupação das terras pelos representantes do capital internacional, que anexando os sistemas de objetos e ações distintivos do plantio, armazenamento e comercialização do circuito produtivo do café, colocou a região Noroeste Paulista como totalidade parcial do sistema econômico global em expansão: 
"Livre dos indígenas era possível adentrar mais em direção aos rios Aguapeí/Feio e Tietê e a ocupação poderia se descolar dos trilhos oferecendo terras mais baratas ainda. Para isso, bastavam ser criadas estradas vicinais, perpendicularmente aos trilhos, a partir das estações da C.E.F.N.O.B. (...) A escala do parcelamento agora seria outra, de cunho francamente empresarial, e em 12 de outubro de 1912 é criada a 'The San Paulo Land, Lumber \& Colonization Company' Companhia de Terras, Madeiras e Colonização São Paulo. São sócios majoritários na empresa o coronel Manoel Bento da Cruz, Presciliano Pinto de Oliveira, o inglês James Mellor e o escocês Robert Clark. O capital da sociedade, em boa parte inglês, foi instituído com o valor de 800:000\$000, divididos por 8.000 ações integralizadas” (GHIRARDELLO, 2000, p. 84).

\section{Foto 13: Estrada Aberta no Meio da Mata do Planalto Ocidental Paulista}

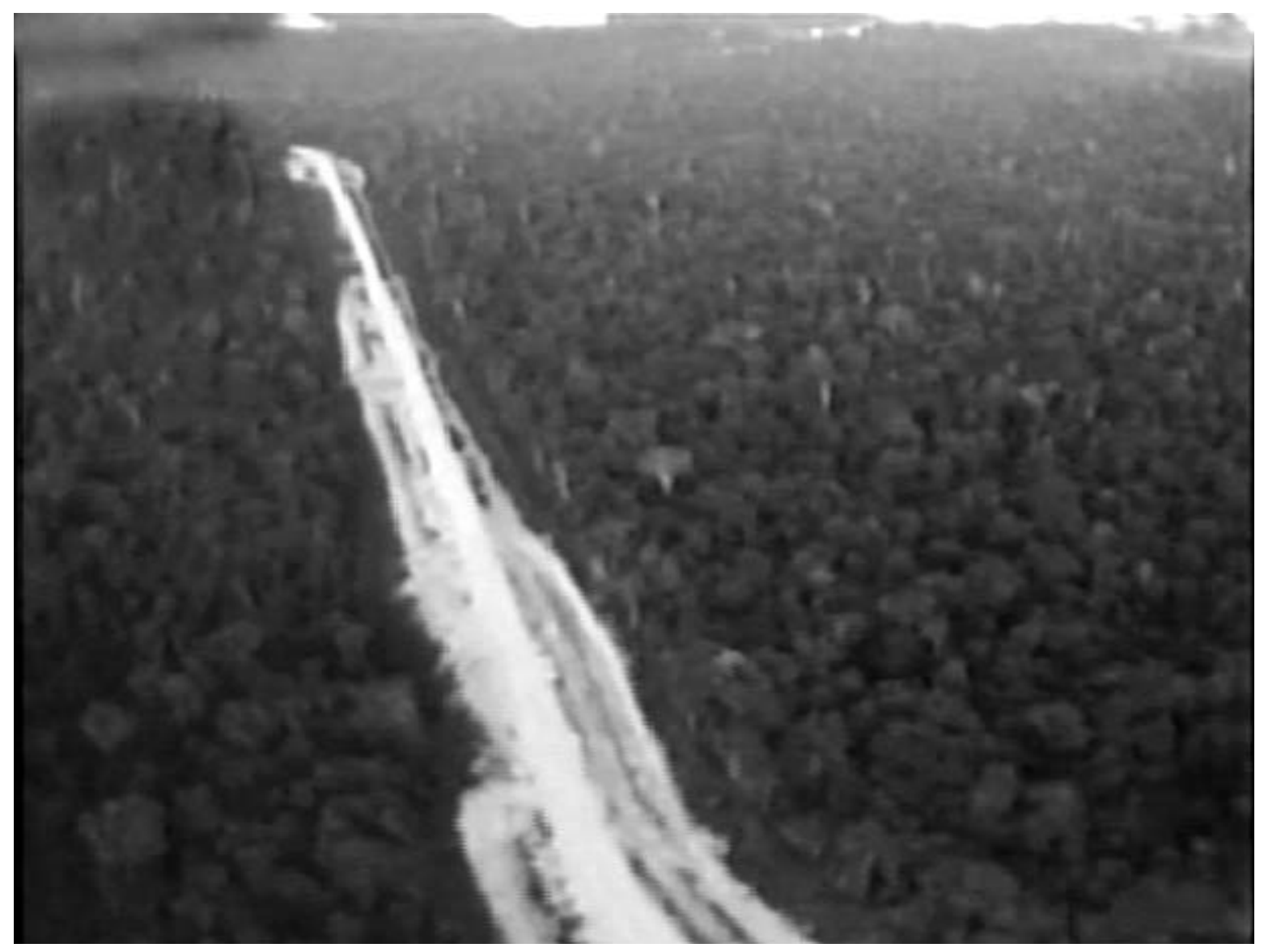

Fonte: Câmara Municipal de Araçatuba (sem data).

A Companhia adquiriu a organização de terras reconhecidas pelo governo e fez o levantamento geral de uma área de 60 mil alqueires de matas virgens situadas entre as vertentes do rio Feio e do rio Tietê. 


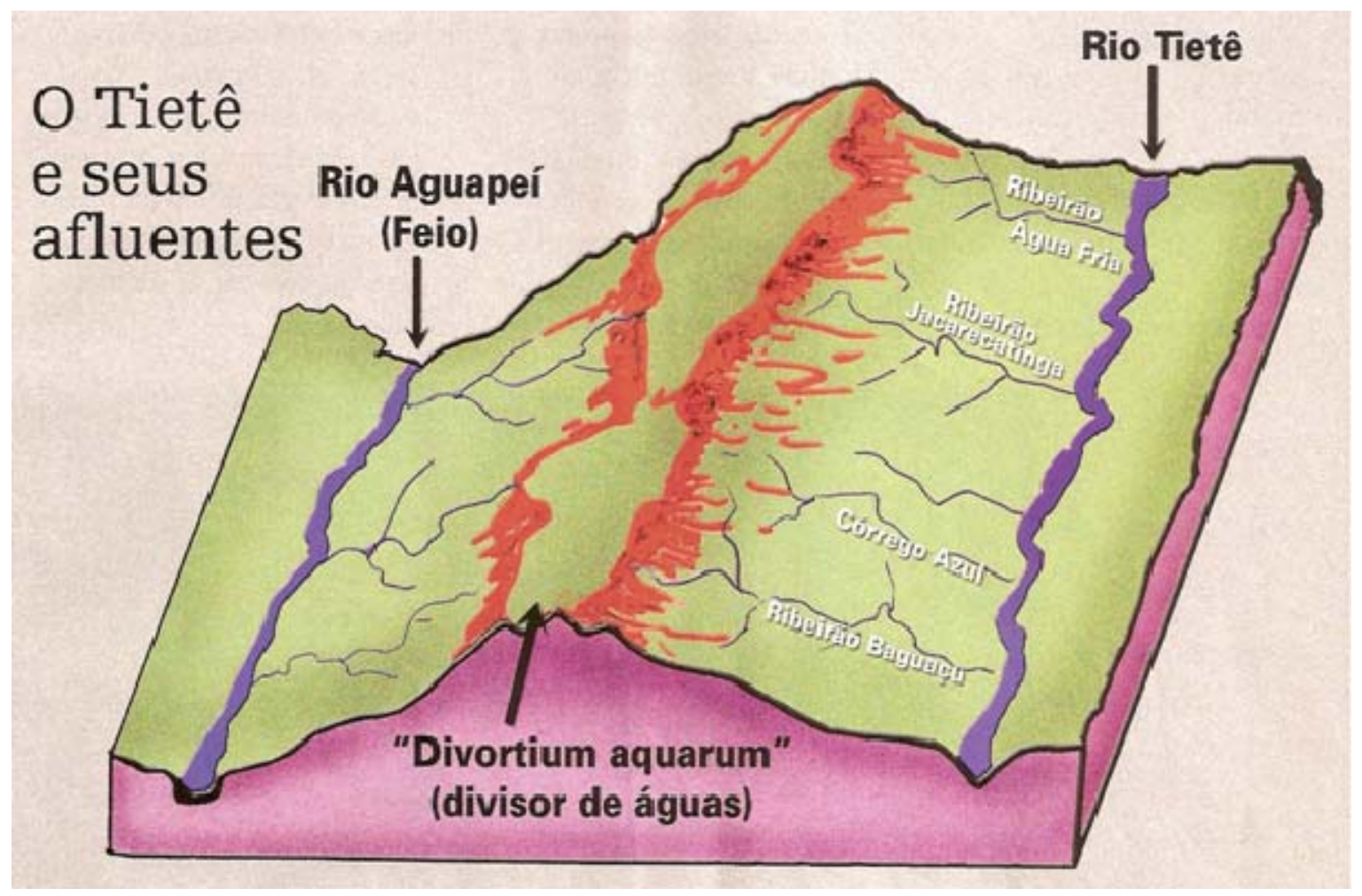

Fonte: Folha da Região, Coleção Araçatuba 100 Anos, Fascículo 1, pág. 11, Julho de 2008.

Em 10 anos, já em 1922, já havia se dividido em lotes 38.434 alqueires distribuídos à 2.032 sitiantes nacionais, portugueses, espanhóis, japoneses e italianos (Martins \& Ramos, 1961) ${ }^{18}$.

\footnotetext{
${ }^{18}$ Com dimensões a partir de 10 alqueires, pagos parceladamente, 30\% à vista e o restante em 3 anos com juros de $10 \%$. Seu público foram prioritariamente imigrantes italianos que já tinham guardado algum dinheiro, principalmente nas roças de café da região de Ribeirão Preto (MONBEIG, 1998).
} 


\section{Foto 14: Clareira Aberta por Queimada}

\section{para Instalação da Lavoura de Café}

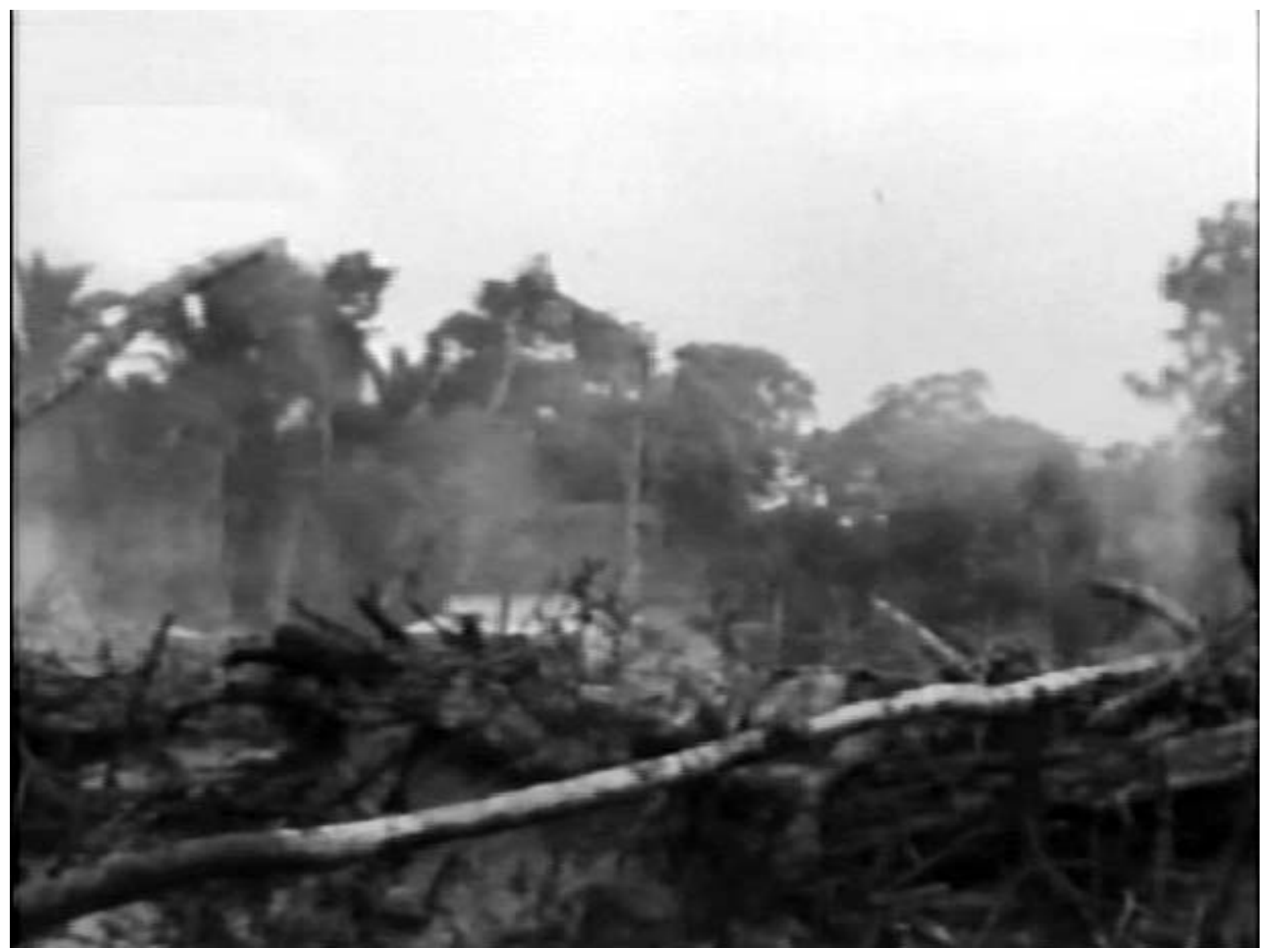

Fonte: Câmara Municipal de Araçatuba (sem data).

Abriu a Companhia de Terras, Madeiras e Colonização São Paulo 700 quilômetros de estradas de penetração entre a estrada de ferro e o Rio Feio. Fundou vilas onde foram levantadas as lojas de comércio para abastecimento dos sitiantes e os centros de venda e beneficiamento do café. Tudo isso possibilitou uma valorização enorme nos preços das terras da região. 


\section{Foto 15: Colheita de Café em Colônia Japonesa na Região de}

\section{Araçatuba}

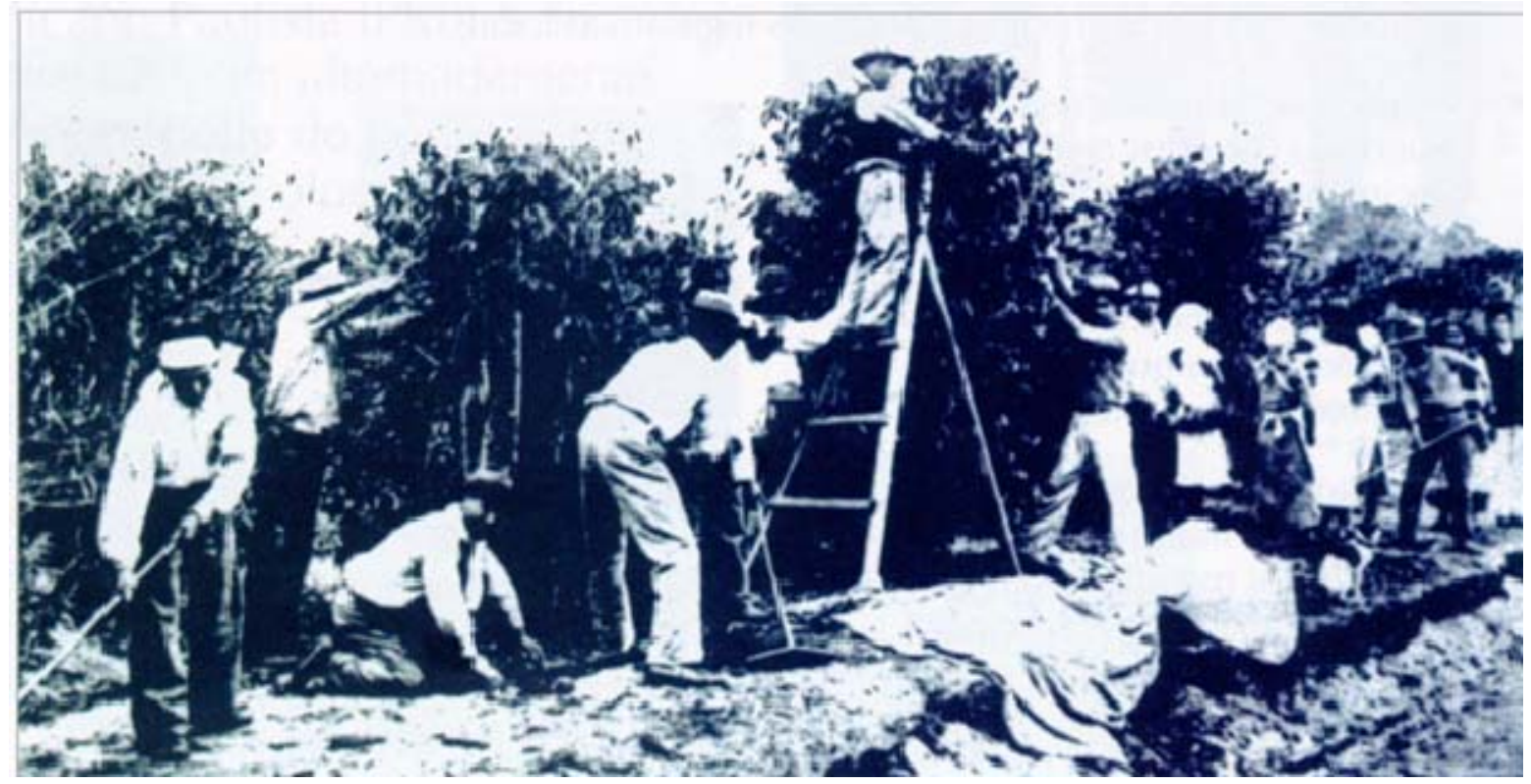

Fonte: Câmara Municipal de Araçatuba (sem data).

Seguindo mais ao oeste, em direção às barrancas do Rio Paraná, tivemos a ocupação de uma porção territorial da Noroeste que ficou conhecida como 'Variante'. Seguindo os trilhos rumo ao Mato Grosso, a Companhia de Estradas de Ferro, mesmo sob orientações e divergências decidiu realizar o traçado da ferrovia de Araçatuba até o rio Paraná às margens do rio Tietê e não mais pelo espigão como ocorrera até então. Sua construção foi feita entre 1908 e 1910 (Pinheiro \& Bodstein, 1997).

A insalubridade do terreno - com a morte de dezenas de trabalhadores da construção da ferrovia de malária e leishmaniose - e a péssima condição dos trilhos construídos com materiais de baixa qualidade levaram essa linha e a região que a circunda (Araçatuba-Itapura) ao abandono (Falleiros, 1999).

Os atritos políticos e jurídicos em relação à posse da terra de Araçatuba ao Mato Grosso - na chamada Fazenda Aguapeí - também adiou a ocupação em direção ao rio Paraná. Vislumbrando a valorização das propriedades com a extensão dos trilhos da Noroeste e a expansão do mercado consumidor do café no mundo, duas companhias de colonização se 
auto-proclamaram donas das terras da Variante. Esse conflito percorreu de 1910 a 1930, ficando Araçatuba (“Boca do Sertão”), durante a década de 1920, marcada pela violência entre esses dois grupos (Pinheiro \& Bodstein, 1997).

Com a passagem da penhora do fruto pendente e do fruto colhido no lugar da hipoteca imóvel como garantia de pagamento do capital de custeio emprestado junto aos bancos para a realização da produção, é o valor dessa produção que dá o preço da terra (Martins, 1996). Assim, durante esse período, com a subida do café no mercado mundial, as terras em litígio da fazenda Aguapeí aumentaram seu valor de 10 para 100.000 réis. Nesse processo, cada grupo ocupou parte da propriedade, derrubaram as matas, plantaram milhares de cafeeiros e construíram pastos para a criação de gado. Como bem coloca Rego (1990):

\begin{abstract}
"O importante, naquele momento, era, através da produção, assegurar a efetiva posse das terras. Tanto é assim que, mesmo toda essa área estando em litígio, (...), a terra estava sendo vendida a grandes e pequenos produtores e o café avançava no rumo lesteoeste, enquanto o gado avançava de oeste para leste" (REGO, 1990, p. 19) ${ }^{19}$.
\end{abstract}

Devido a essa instabilidade econômica gerada pelo conflito, não saiu do papel até a década de 1930 a construção de uma linha de ferro entre Araçatuba e o Mato Grosso, ficando adiado o projeto de aceleração da integração do território nacional via essas duas regiões. Diferente do anterior, o novo traçado planejava cortar as terras em litígio pelo espigão divisor de águas entre o rio Feio e o rio Tietê.

Manoel Bento da Cruz também tomou parte no embate pela posse da fazenda Aguapeí. Financiado por capitais ingleses e banqueiros da capital paulista e federal, o coronel fundou uma companhia de colonização para a área, derrubou muitos hectares de mata, comercializou a madeira, plantou milhares de cafeeiros, abriu invernadas para engorda de gado e construiu a famosa Estrada Boiadeira, onde cobrava pedágio para quem nela entrava e

\footnotetext{
${ }^{19}$ A ocupação do café se dava no espigão divisor de águas dos rios Feio e Tietê, ficando as pastagens nas áreas mais baixas, junto às várzeas dos rios. Evitava-se o plantio do café nos fundos de vale para evitar a perda da produção com as geadas (Monbeig, 1998).
} 
saía (Pinheiro \& Bodstein, 1997). A balsa para travessia do rio Paraná - que passou a deslocar parte do gado de Mato Grosso e transformou os fundos de vale da Variante em locais de engorda rumo aos matadouros de Barretos e São Paulo - e a construção da primeira usina hidrelétrica na região foram também obras de Bento da Cruz (Rego, 1990).

\section{Foto 16: Balsa (Ferroboaty) Usada para Travessia de Rio}

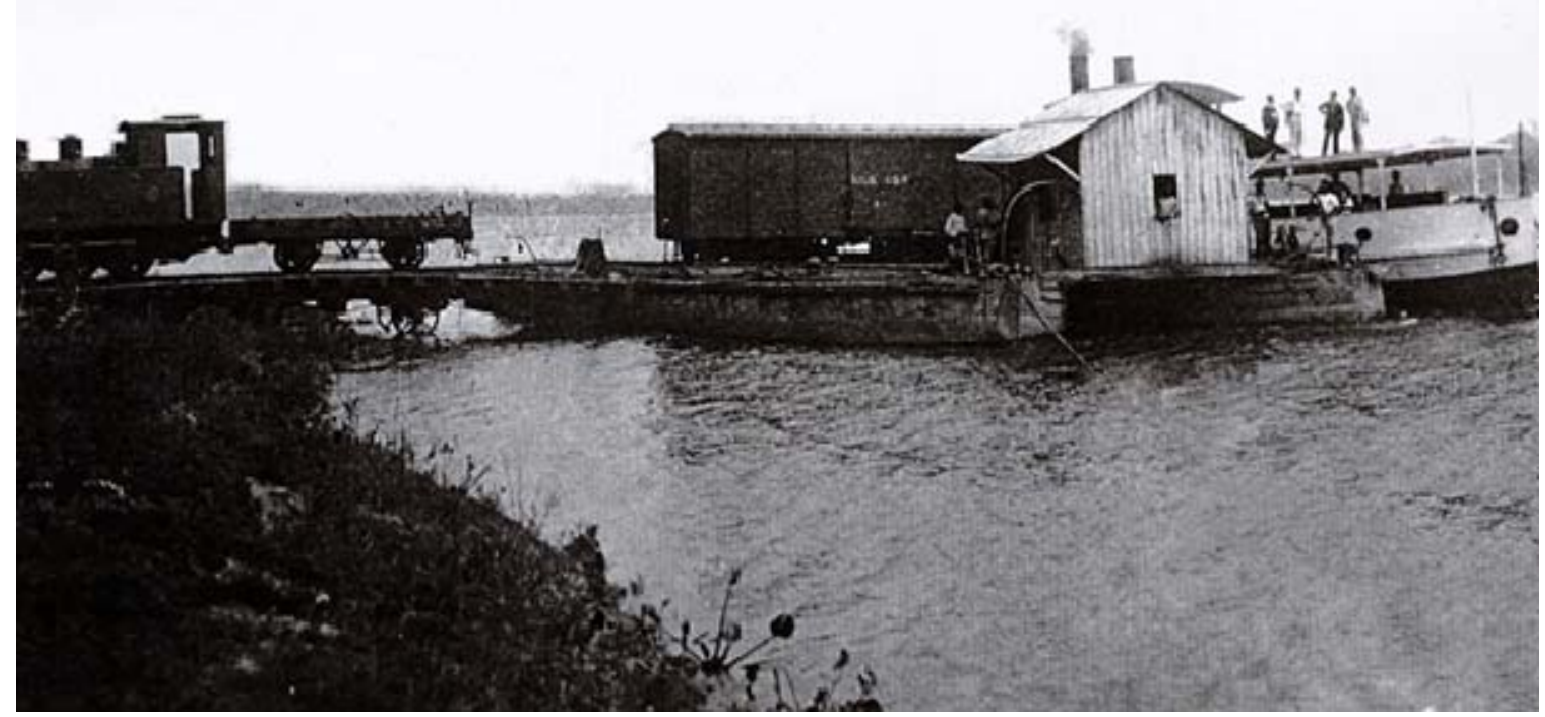

Fonte: Câmara Municipal de Araçatuba (sem data).

Em 1929, com a crise da economia mundial, diminuiu-se a demanda pelo café, caindo seu preço. Nesse rearranjo interno da economia brasileira, diminuíram os conflitos pelas terras da Aguapeí, que tiveram seus valores relativos em queda comparados ao período anterior. No decorrer da década de 1930, sai do papel a construção da linha Variante - que deu nome a essa porção territorial - com trajeto Araçatuba-Jupiá. 
Mapa 4: Malha Ferroviária Constituída no Espaço Geográfico Paulista

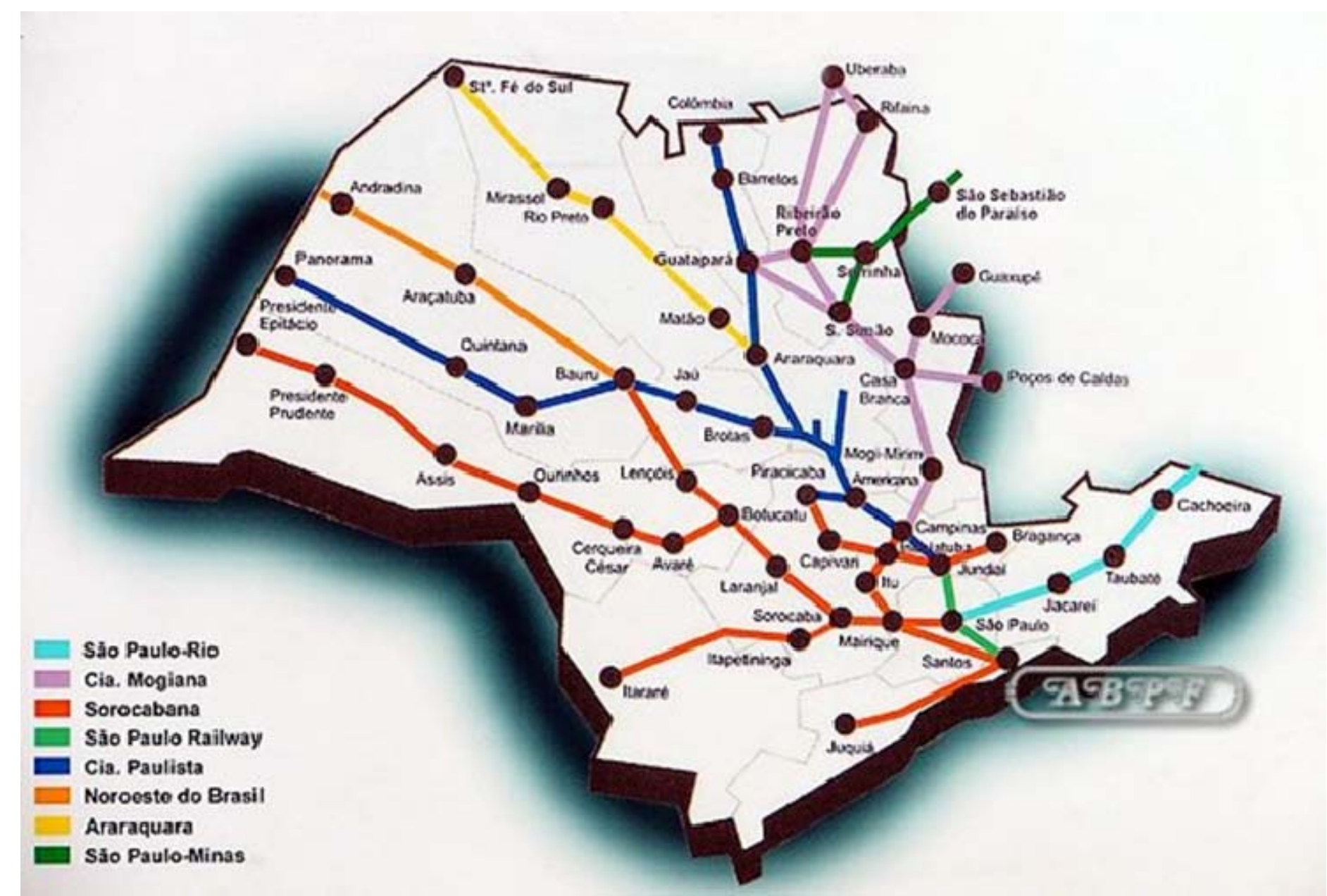

Fonte: Associação Brasileira de Preservação Ferroviária (ABPF), http://www.abpfsp.com.br/ferrovias.htm, Acesso Disponível em 04/09/2008. 
Como ocorreu desde Bauru, da beira das estações da Companhia de Estradas de Ferro Noroeste do Brasil (C.E.F.N.O.B) após Araçatuba surgiram povoados que logo se emanciparam: Guararapes, Valparaíso, Guaraçaí e Andradina. Com a expansão da cultura do café em meados da década de 1920, a Zona Noroeste Paulista é vista como sonho de enriquecimento por pessoas de várias regiões do Brasil e do mundo. Falleiros (1999) mostra como milhares de nordestinos se deslocaram para a região para trabalhar na derrubada da floresta e construção da ferrovia, ali ficando por toda a vida.

\section{Foto 17: Estação Ferroviária de Andradina}

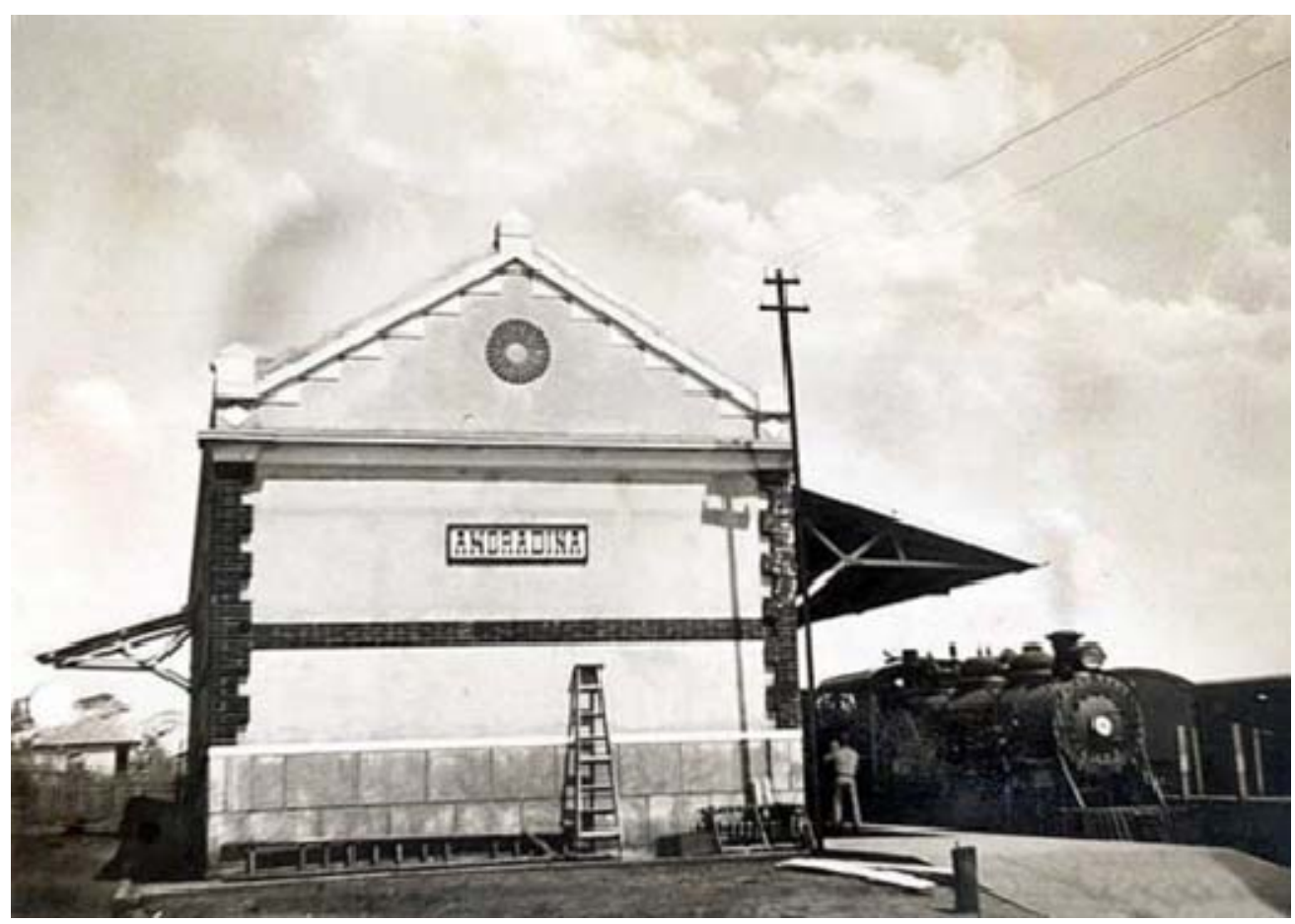

Fonte: http://www.estacoesferroviarias.com.br/a/andradina.htm, Acesso Disponível em 29/08/2008. 
Sobre essa mobilidade de força de trabalho, Monbeig (1998) diz:

\begin{abstract}
"Durante cinco anos, de 1926 a 1930, as zonas rurais do Estado de São Paulo receberam um contingente de 233.202 trabalhadores estrangeiros e nacionais que passaram pela Hospedaria dos Imigrantes (...) Os espigões onde o aumento dos cafezais havia sido mais acentuado, eram os maiores chamarizes: para lá foram $31,1 \%$ dos imigrantes. A parte do leão coube à Noroeste que, sozinha, drenou mais do que $1 / 4$ da imigração paulista (26,6\%), ou seja, 62.205 indivíduos. Alguns municípios concentraram pequenos exércitos de trabalhadores rurais, como foi o caso de Araçatuba, a mais ocidental, com 13.365 imigrantes". (MONBEIG, 1998, p. 193).
\end{abstract}

\title{
Foto 18: Panorâmica da Expansão Urbana de Araçatuba
}

\section{nas Primeiras Décadas (fotografia tirada da periferia da cidade)}

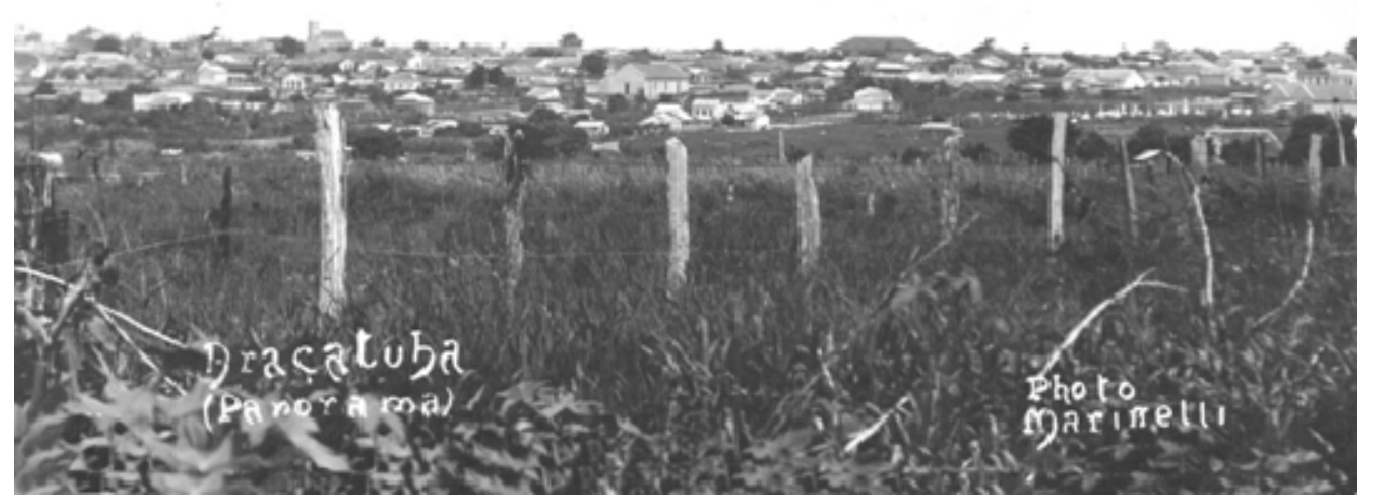

Fonte: Câmara Municipal de Araçatuba (sem data).

Constituindo a espacialidade populacional da região, nas áreas urbanas se localizavam, além da estação ferroviária, a igreja, as casas de comércio, as casas bancárias, os armazéns de estocagem, as vendas de produtos alimentícios e de primeiras necessidades e as residências daqueles que trabalhavam na prestação desses serviços urbanos. 
Foto 19: Vista Parcial da Expansão Urbana de Araçatuba

nas Primeiras Décadas (fotografia tirada do centro da cidade)

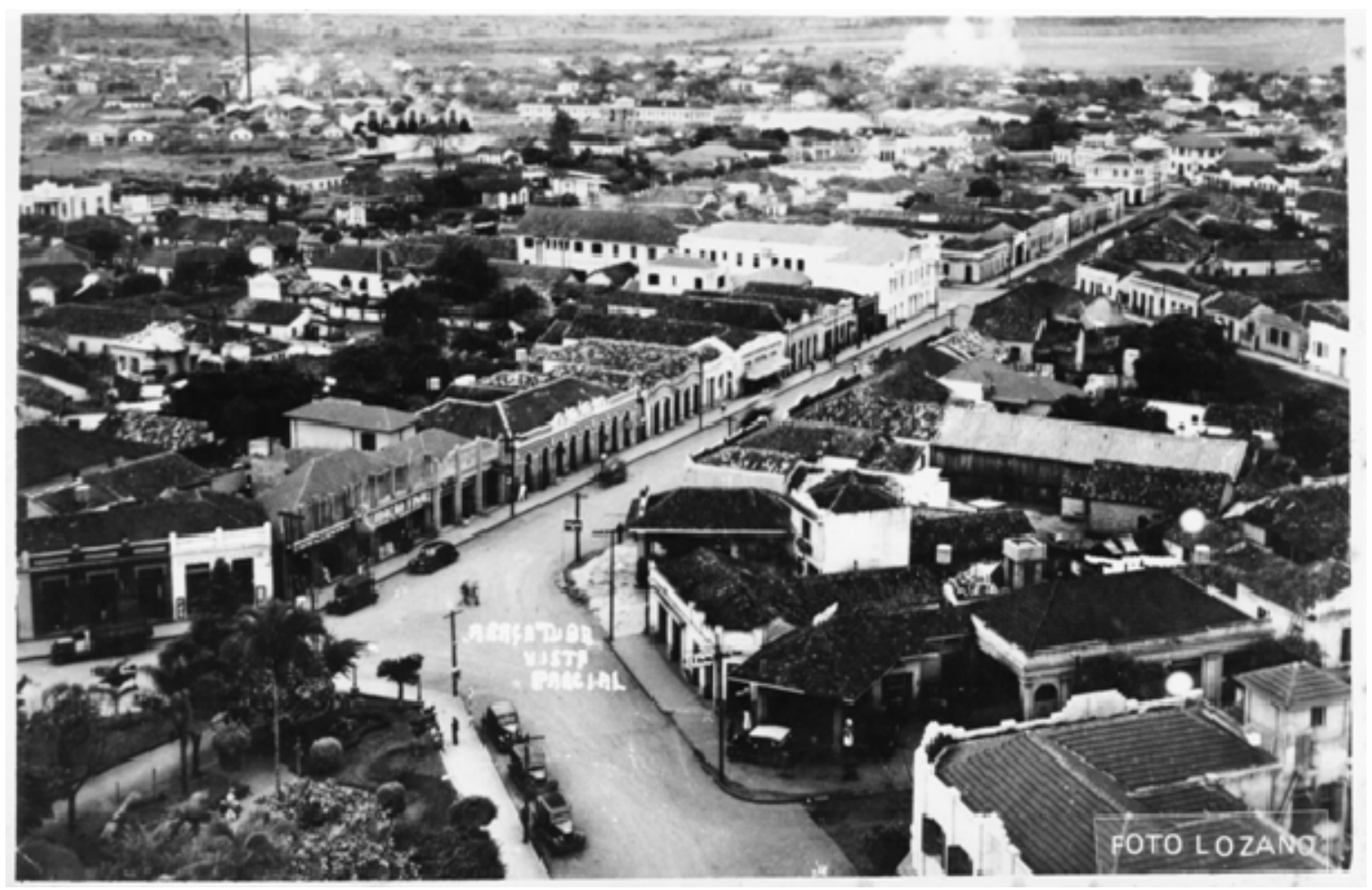

Fonte: Câmara Municipal de Araçatuba (sem data).

A grande maioria da população, morava nas áreas rurais. Como o trato da lavoura necessitava de mão-de-obra o ano todo, cada grande proprietário dispunha em suas terras de uma pequena vilinha - a colônia onde viviam os trabalhadores rurais (colonos), no característico regime de trabalho denominado colonato. Mesmo os pequenos e médios proprietários tinham suas residências no campo, o que fazia da Noroeste Paulista nesse primeiro momento, como em todo o interior do país, uma região pouco urbanizada. As cidades eram as localidades "nó” onde os representantes do capital financeiro nacional e internacional gerenciavam o escoamento das mercadorias e de toda riqueza produzida nas terras da região. 
Foto 20: Colônia Rural Japonesa na Hinterlândia de Araçatuba

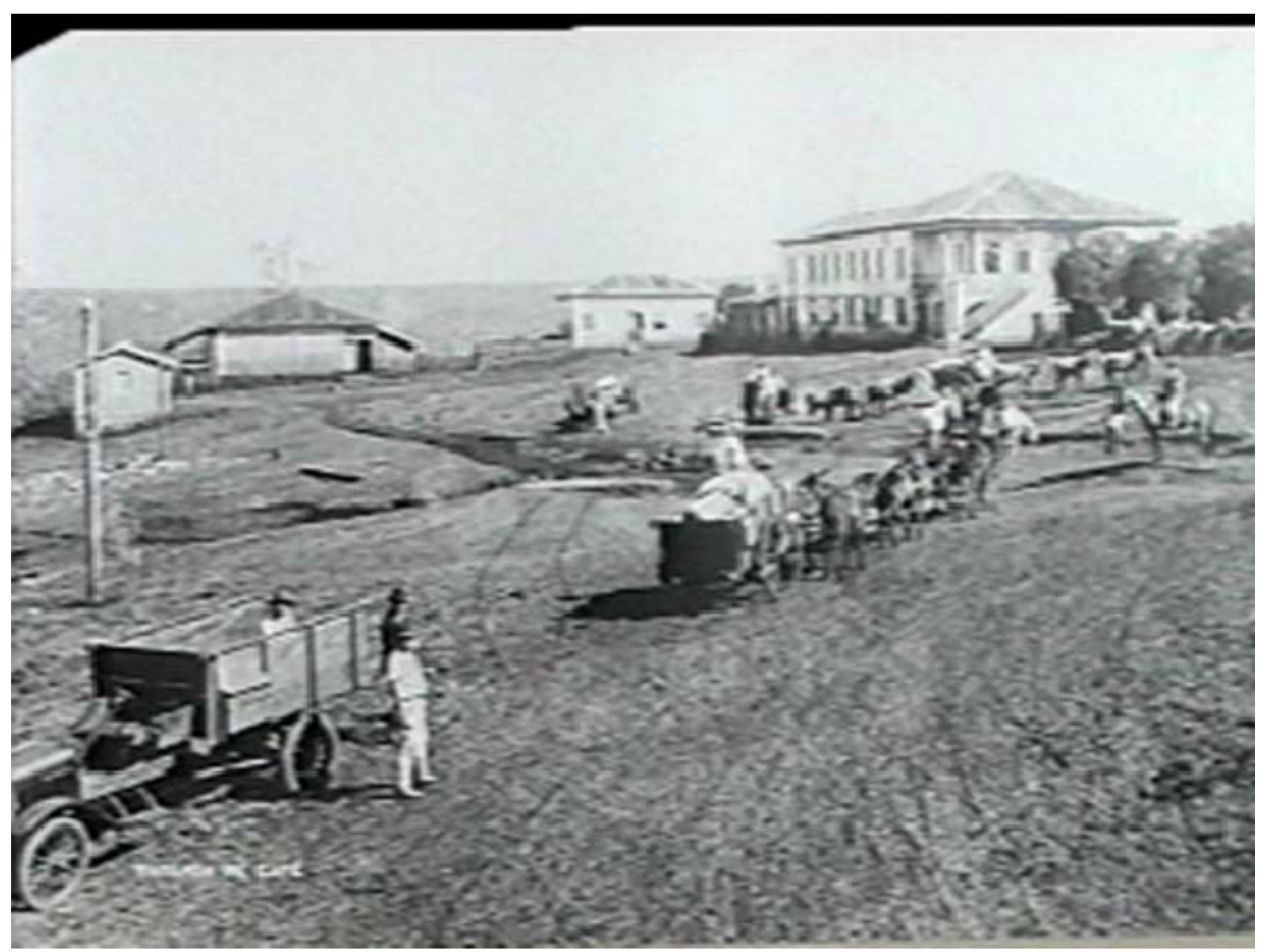

Fonte: Câmara Municipal de Araçatuba (sem data). 


\section{Capítulo 2}

\section{O Circuito Produtivo Algodoeiro na Região de Araçatuba}

Como o quadro de predominância quase absoluto do café se abalou com a crise mundial do sistema capitalista em 1929, foi lançada a base do modelo de acumulação no Brasil para uma estrutura produtiva mais moderna, sedimentada na indústria.

Continuidade de um período transitório, a década de 1930 e início da de 1940 estabeleceu "um começo de integração nacional e um início da hegemonia de São Paulo, com o crescimento industrial do país e a formação de um esboço de mercado territorial localizado no Centro-Sul” (SANTOS \& SILVEIRA, 2001, p. 37). Portos e estradas de ferro possibilitaram a interligação criadora de uma rede brasileira de cidades. As cidades industriais passam a comandar os fluxos sobre o espaço regional onde elas estão localizadas, ou seja, efetiva-se uma nova hierarquia entre os lugares criada pela disseminação do sistema técnico industrial em pontos do território brasileiro. Centralizado no Rio de Janeiro e em São Paulo, será essa última cidade, a partir do sistema de engenharia em montagem desde o período do café, que controlará cada vez mais os fluxos de uma economia nacional em construção.

Este novo momento econômico se inicia com o governo de Getúlio Vargas, que representou as aspirações democráticas almejadas pela classe média urbana e pela burguesia industrial. Baseado em um forte intervencionismo, principalmente político nas províncias, o governo Vargas desencadeou uma visão integradora do território nacional pelas políticas públicas estatais. Novos trechos de ferrovias foram anexados ao território (como na Estrada de Ferro Vitória-Minas) e alguns trajetos interligados (no caso da Estrada de Ferro Noroeste do Brasil, o trecho paulista se interligou ao mato-grossense). Regiões de matérias-primas se aproximaram das novas áreas industriais. Com a criação do Conselho Nacional do Petróleo (1938), da Companhia Siderúrgica Nacional (1941) e da Companhia Vale do Rio 
Doce (1943) se institucionalizou as bases para que o país se desenvolvesse, construindo internamente suas indústrias de bens de capitais ${ }^{20}$.

Como parte dessas mudanças, no setor agrícola, a oligarquia agroexportadora brasileira perde espaço no novo reordenamento do poder político nacional $^{21}$. Diante de pressões demandantes de reformas no eixo das ações de desenvolvimento do país, a agricultura passa a ter como principal papel ofertar alimentos às cidades industriais em crescimento. Analisando os planos de governo e suas políticas implementadas de 1930 até $1964^{22}$, Espírito Santo (2005) conclui que eles se limitaram em posicionar a agricultura com essas duas funções: abastecimento do mercado interno e exportação criadora de divisas.

Como exemplo de culturas agrícolas que exerceram essas funções, na Noroeste Paulista, com o declínio da cultura cafeeira após a crise do capitalismo em 1929, são o algodão e a pecuária extensiva que passam a fazer uso de grande parte do espaço geográfico dessa porção da província

\footnotetext{
${ }^{20}$ Esse feito se efetivou no findar da $2^{\text {a }}$ Guerra, quando o Brasil passou a possuir, por exemplo, sua indústria de auto-peças.

${ }^{21}$ Contudo, podemos considerar, nas políticas agrícolas, que o governo da Revolução de 1930 e os posteriores até 1960 foram limitados, pois não implementaram reformas como as acontecidas nos países centrais do capitaslismo no que se refere à estrutura técnica e fundiária. Para se ter uma idéia, as burguesias industriais do mundo desenvolvido viram na concentração de terras um resquício feudal que impedia o desenvolvimento do capitalismo, e promoveram a reforma agrária em seus territórios. No Brasil, aconteceu diferente. A burguesia industrial passa a ter o poder político para a realização dessas reformas, configurado na instalação do modelo de substituição de importações estimulador e fortalecedor da indústria nacional e do mercado interno. Contudo, no que se refere à reforma agrária, essa burguesia industrial não agiu como nos países desenvolvidos. Segundo Martins (1997), "Entre as velhas elites e as novas elites estabelecera-se uma espécie de compromisso político, mediante o qual os industriais e os grandes comerciantes tornaram-se grandes clientes políticos das oligarquias, às quais delegaram suas responsabilidades de mando e direção, reproduzindo os mesmos mecanismos políticos que vitimavam todo o povo e impediam um efetivo desenvolvimento" (MARTINS, 1997, 20). Sobre essa mesma realidade, Sorj (1982) relata: “A situação que se configura a partir de 1930 é o deslocamento dos grandes proprietários rurais da direção do Estado, visto que tanto as políticas econômicas quanto o conjunto da estrutura política se centram agora no setor urbano-industrial. Esse deslocamento, porém, não chega a eliminar os grandes proprietários fundiários da estrutura política, que permanecem no bloco do poder, mas em uma posição subordinada” (SORJ, 1982, p. 21). Essa força mantida pela oligarquia rural brasileira possibilitou conquistas frente ao novo governo estabelecido. Em Espírito Santo (2005) é mostrado que: “Após a 'Revolução de 30', o Estado definitivamente age em nível federal e aplica políticas de fomento e apoio, criando ou readequando instituições e órgãos governamentais, os quais vieram a compor um forte esquema de apoio aos interesses da oligarquia rural” (ESPIRITO SANTO, 2005, p.46).
}

${ }^{22}$ Além dos planos do primeiro governo getulista, o autor analisou o Plano Salte (1950-1954), o Plano de Metas (1956-1961) e o Plano Trienal de Desenvolvimento Econômico e Social e o Plano de Ação Econômica do Governo (PAEG - 1964-1966). 
paulista $^{23}$. Não acarretada somente pela demanda da indústria nacional, a expansão da cultura algodoeira em São Paulo se relacionou fortemente com o fim de sua atividade em alguns territórios estrangeiros, o que desequilibrou a oferta desse produto no mercado internacional. Assim, a crise de 1929 que iria lançar a cafeicultura em longo período de graves dificuldades, colocou os cafeicultores na contingência de tentar novas explorações que viessem compensar a perda de renda por eles sofrida. Dentre as diversas explorações agrícolas então ensaiadas, a do algodão era uma daquelas que melhores perspectivas apresentavam, devido ao seu alto preço no mercado internacional (MONBEIG, 1998).

\section{1) Novos Conteúdos do Momento Algodoeiro}

Reordenando sua funcionalidade na divisão internacional e territorial do trabalho, a principal especialização nesse momento na atividade algodoeira das terras da Noroeste Paulista trouxe novos objetos e ações para a constituição do espaço geográfico regional. Do circuito algodoeiro, grandes indústrias de beneficiamento se instalaram, diferente das pequenas que foram construídas para beneficiar o café. " $A$ superestrutura capitalista está melhor organizada quando se trata da jovem cultura algodoeira, do que quando se relaciona com a tradicional cultura do café” (MONBEIG, 1998, p.301). Anderson Clayton, SANBRA, Indústrias Reunidas Francisco Matarazzo, Saab SA. e algumas Cooperativas - japonesas principalmente - construíram suas fábricas em quase todos os municípios da região de Araçatuba na época, concentrando-se num primeiro período nos municípios a leste, estendendo-se timidamente a partir de 1940 até à divisa com o Mato Grosso. Além de beneficiar o algodão, produziam óleo, tecidos e exportavam seus produtos em grande escala (REGO, 1990).

\footnotetext{
${ }^{23}$ Usando a infra-estrutura recebida do período cafeeiro, na região de Araçatuba o algodão se desenvolveu principalmente em pequenas propriedades, sendo também plantado em grandes áreas na formação de pastos para as invernadas. "A meação desenvolveu-se paralelamente ao arrendamento $e$, finalmente, conquistou o fazendeiro, no momento em que a criação de gado revelou-se um excelente negócio. (...) Já vimos como se distribuíam as formas de ocupação do solo nas grandes fazendas, por exemplo na fazenda Aguapeí, que além do cafezal, tem mais de 11.000 hectares de campos em desflorestamento. Essas pastagens recentes e derrubadas atuais são obras de meeiros plantadores de algodão" (MONBEIG, 1998, p. 286).
} 
Foto 21: Indústria Beneficiadora de Algodão SANBRA em Araçatuba

(Anos 1930-1940)

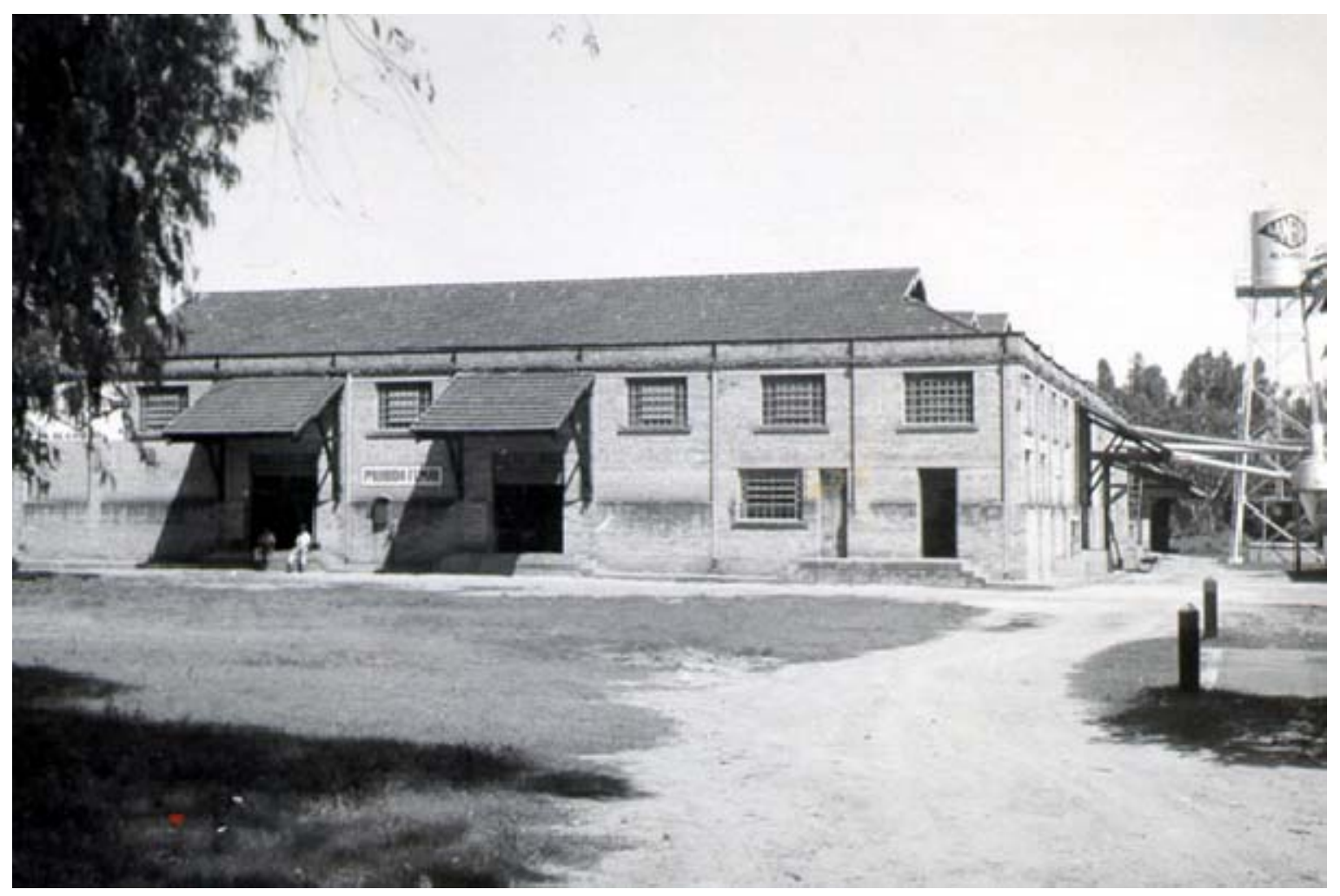

Fonte: Câmara Municipal de Araçatuba (sem data).

Capitais americanos, ingleses, japoneses e brasileiros foram investidos de forma substancial na produção do algodão (MONBEIG, 1998), fazendo de seus detentores e aliados os atores hegemônicos desse novo momento da Noroeste Paulista. Com a situação política inquietante no Sudão - colônia britânica -, os ingleses e americanos inverteram seus investimentos no oeste paulista, sendo a Anderson Clayton e SANBRA as marcas representantes de seus capitais. As companhias colonizadoras japonesas agiram através de suas Cooperativas, promovendo a fixação de 
seus imigrantes nos loteamentos organizados em todo o oeste do estado de São Paulo (Noroeste e Sorocabana principalmente) ${ }^{24}$.

Fotos 22 e 23: Embarques de Algodão em Colônias Japonesas

\section{Rumo à Ferrovia na Região de Araçatuba}
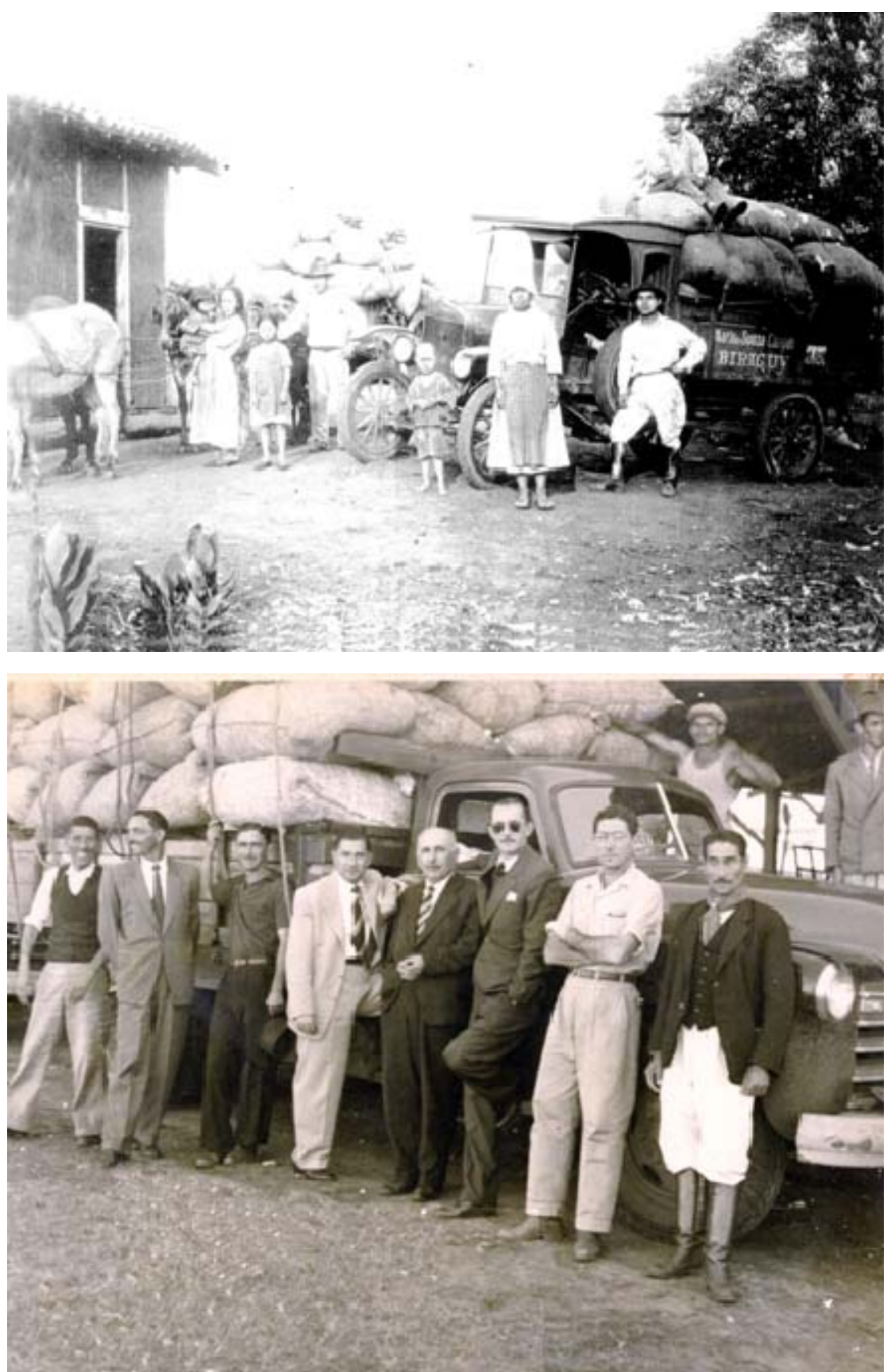

Fonte: Câmara Municipal de Araçatuba (sem data).

${ }^{24}$ O Japão vivia uma crise econômica com uma superpopulação. Isso acarretou uma emigração para várias regiões do mundo, principalmente para o Brasil (NOGUEIRA, 1973). 
Foram anexações inovadoras ao espaço geográfico regional do processo de industrialização brasileiro. Foi a totalização parcial de um novo momento, onde dos fixos urbano-industriais materializados pela intencionalidade de interesses longíquos se passam a comandar com maior rigidez o funcionamento dos sistemas de objetos e ações das áreas rurais.

Essas empresas financiavam os pequenos produtores. Sem acesso ao crédito institucionalizado, esses lavradores acabavam se comprometendo a entregar sua produção a essas grandes companhias, mediante um adiantamento, pois a Carteira de Crédito Agrícola e Industrial (CREAI) do Banco do Brasil, criada em 1937, mesmo tendo sido o crédito agrícola no país que começou a ser organizado de forma racional e em escala ampla, na base de orçamentos de despesas calculados com mais lisura do que nos períodos anteriores, não dispunha de agências em todo o território e não contava com recursos para atender devidamente aos financiamentos de prazo longo, de que os agricultores necessitavam para a construção de benfeitorias, aquisição de veículos, máquinas e outros insumos modernos essenciais à modernização da agricultura. Sobre a situação desses homens da terra, Monbeig diz que:

“... estão sob a dependência das grandes empresas nacionais ou estrangeiras. (...). Como são elas as grandes distribuidoras de crédito aos sitiantes, toda a produção algodoeira cai sob o controle de algumas empresas possantes que, por outro lado, são detentoras de uma boa parte das indústrias conexas e são donas do comércio de exportação” (MONBEIG, 1998, p.300).

A partir do traçado das estradas de terra construídas no momento cafeeiro, outras foram anexadas, melhorando a fluidez do deslocamento das pessoas e dos produtos agrícolas da zona rural para as cidades (Pinheiro \& Bodstein, 1997). Dos municípios atravessados pela estrada de ferro Noroeste do Brasil - que continuou sendo a espinha dorsal da comunicação regional às outras regiões do espaço geográfico brasileiro e do mundo escoavam-se as mercadorias, principalmente o algodão e seus derivados beneficiados nas indústrias localizadas em Araçatuba e nos municípios de seu entorno. Eram das cidades onde se contabilizavam os lucros das 
atividades produtivas e os encaminhavam para seus controladores nas maiores cidades do país e no exterior.

\section{Foto 24: Antiga Estrada Araçatuba-Birigui}

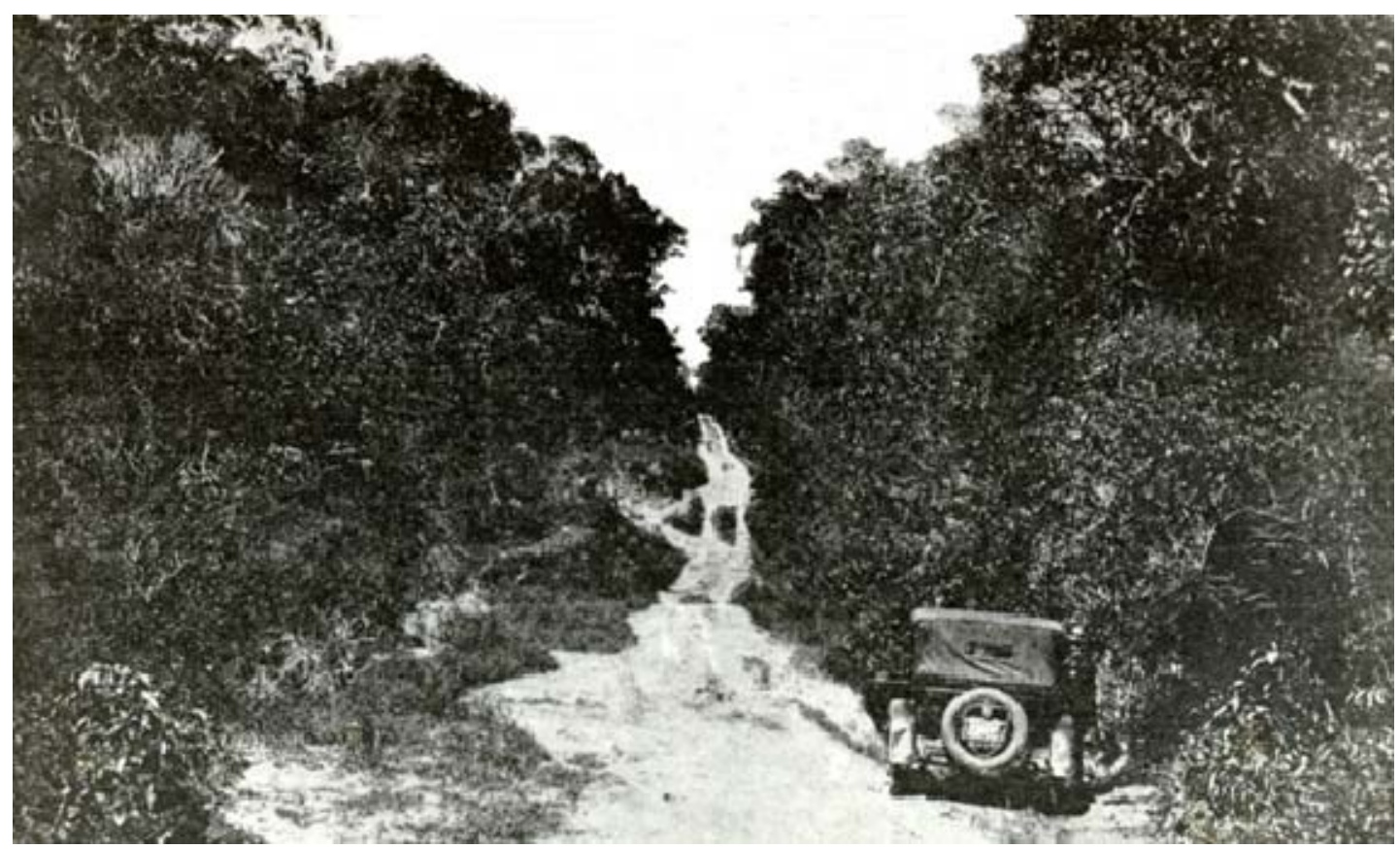

Fonte: Câmara Municipal de Araçatuba (sem data).

Diversifica-se o meio técnico na região, demandando-se mão-deobra e consequentemente mercadorias básicas para consumo. Cresce o número de unidades beneficiadoras de produtos agropecuários e fábricas de alimentos durante a década de 1930 (Pinheiro \& Bodstein, 1997). Culturas alimentares intercaladas ao algodão - principalmente arroz, feijão, milho, pecuária leiteira, avicultura e suinocultura - eram praticadas pelos sitiantes, que plantavam para a subsistência e para abastecer com o excedente a demanda regional $^{25}$.

\footnotetext{
${ }^{25}$ O café também continuou sendo plantado em menores quantidades após 1929 na Noroeste. Até a década de 1960, manteve uma ocupação ao redor de 30\% das áreas regionais (REGO, 1990).
} 
Fotos 25 e 26: Plantio de Arroz e Criação de Porcos, Respectivamente, em Colônia Japonesa na Região
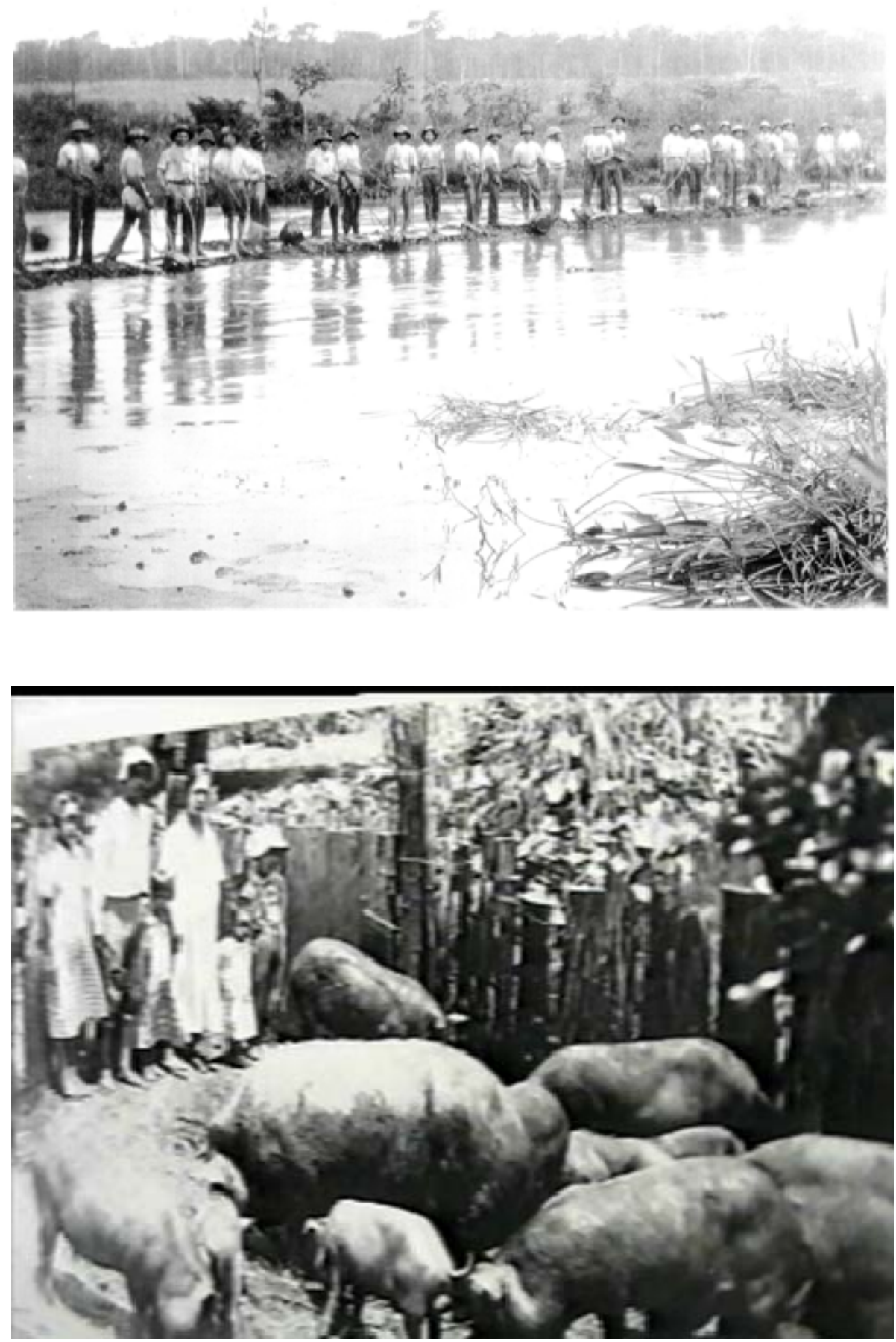

Fonte: Câmara Municipal de Araçatuba (sem data). 
Nas áreas urbanas em ascensão, pequenas fábricas eram acompanhadas

“... pelo movimento de capitais mercantis locais propiciando investimentos de origem privada de companhias de energia, de telefone, de meios-de-transporte, bancos, instituições de ensino, etc. Acrescente-se ainda o surgimento de postos de gasolina, armazéns para venda de implementos agrícolas e sementes, que reforçavam o setor urbano, acelerando a prestação de serviço" (ROSSINI, 1988. p. 74).

Fotos 27, 28, 29, 30 e 31: Respectivamente - Primeira Agência dos Correios; Antiga Central de Iluminação Pública; Antigo Posto de Gasolina; Cinema Antigo; Escola.

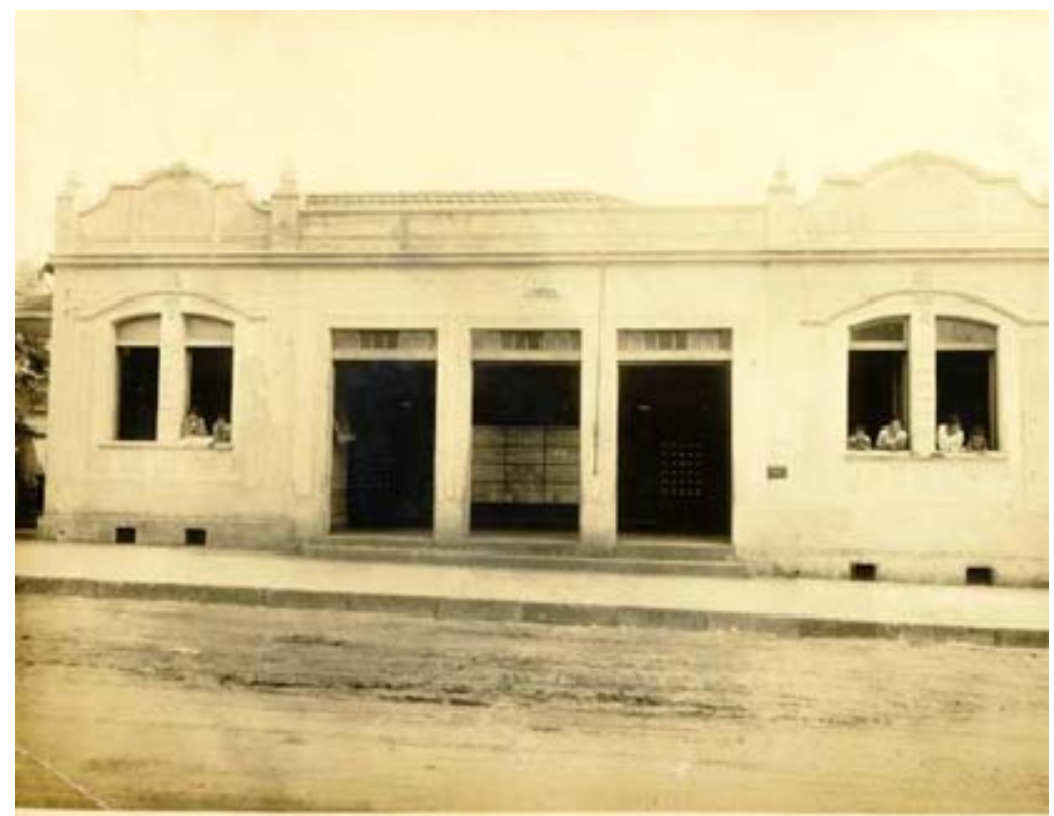



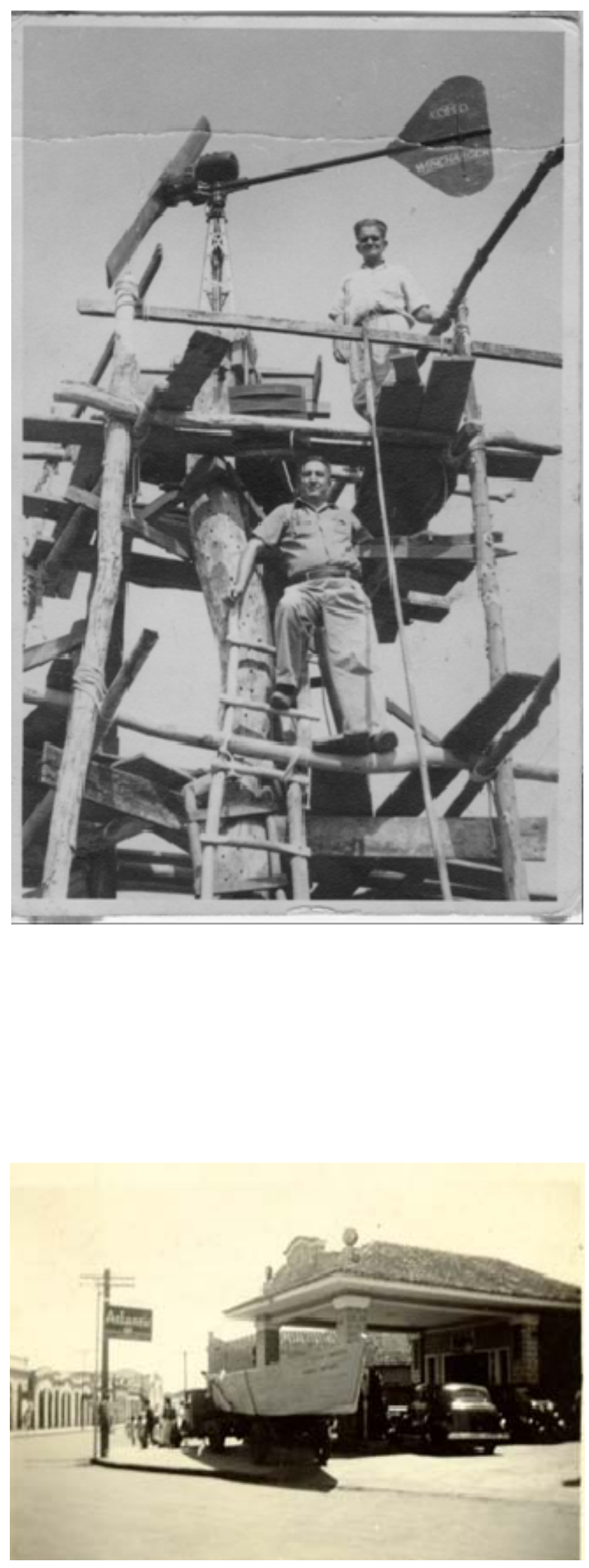

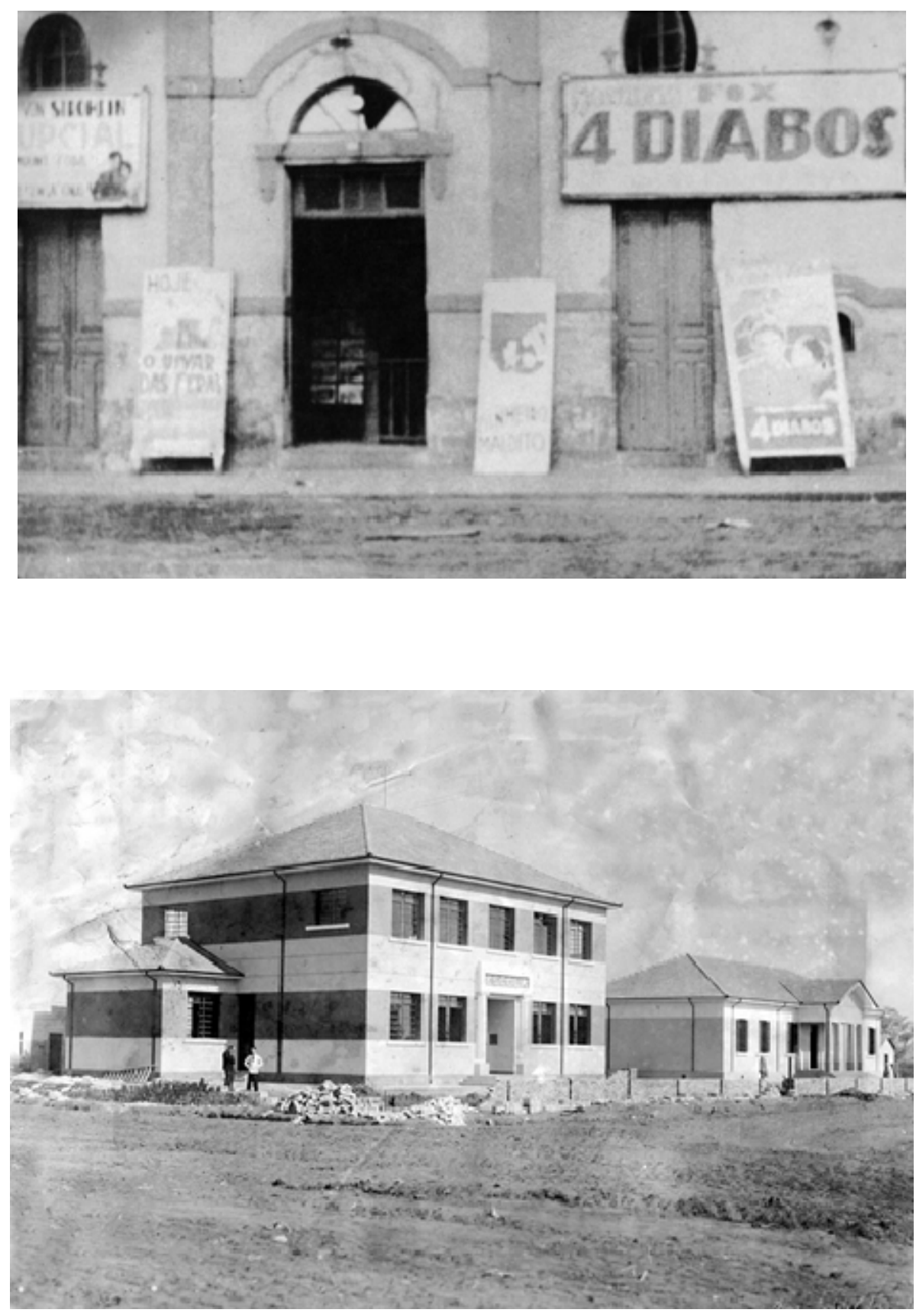

Fonte: Câmara Municipal de Araçatuba (sem data).

Nos anos 1930, os municípios de Araçatuba, Birigui e Penápolis se destacaram como aqueles que apresentaram a maior diversidade e número de empreendimentos. Beneficiamento de café, algodão, e arroz; fiação e tecelagens; curtumes e serrarias; carne, leite e derivados; açúcar, álcool, aguardente, melado e rapadura; vinho e vinagre; massas alimentícias e biscoitos; padarias, confeitarias e pastelarias; derivados de mandioca e 
milho; balas, chocolates, caramelos, doces em conserva e condimentos; fábricas de calçados, de máquinas agrícolas e de carroças; seleiros e ferreiros e torrefação e moagem de café: são essas as atividades de demanda regional, que em pequena escala, instauraram-se na região. Algumas com caráter ainda artesanal, outras já dentro do espírito da industrialização nascente, ou seja, com o uso das modernas máquinas do momento e uma ascendente divisão social do trabalho (Rego, 1990).

Com o término da ligação ferroviária entre Araçatuba e o Mato Grosso, várias vilas surgiram à beira das estações da Companhia de Estrada de Ferro Noroeste do Brasil. No entroncamento das estradas de rodagem, longe da estação ferroviária, algumas colônias também cresceram e fundaram povoados: Auriflama, Bilac, Braúna, Buritama, General Salgado e outras.

Em 1940, na Região de Araçatuba, tinha-se 22 aglomerações municípios e vilas (que como distritos de paz, depois se emancipariam). Possuindo uma população dispersa, que em sua maioria morava nas áreas rurais, no começo dessa década, computava-se 288.474 pessoas. Distribuindo essas aglomerações humanas por classes de população, temos a seguinte distribuição na tabela abaixo:

Tabela 2: Distribuição das Aglomerações Humanas na Região de Araçatuba Segundo Classes de População - (1940)

\begin{tabular}{|c|c|}
\hline Classes de População & 1940 \\
\hline Até 5 mil & 5 \\
\hline De 5 a 10 mil & 9 \\
\hline De 10 a 20 mil & 5 \\
\hline De 20 a 50 mil & - \\
\hline De 50 a 100 mil & - \\
\hline De 100 a 200 mil & - \\
\hline De 200 a 500 mil & - \\
\hline Mais de 500 mil & \\
\hline
\end{tabular}

Fonte: FUNDAÇÃO IBGE, Censo demográfico do Estado de São Paulo de 1940. 
Em decorrência da expansão da estrada de ferro até o Mato Grosso e o surgimento desses novos povoados, durante a década de 1940, o crescimento demográfico regional se deu principalmente com o desenvolvimento dessas localidades surgidas, onde migrantes e imigrantes as escolheram para fazer a vida.

Segundo Costa \& Wong (1982),

"A nível de sub-região, observa-se que a ocupação territorial de Andradina se deu na década de 1940, quando sua população passou de pouco menos de 23.000 para 110.000 habitantes, com uma taxa anual média de crescimento de $15,7 \%$. Esse rápido povoamento se deveu em grande parte à extensão da Estrada de Ferro Noroeste do Brasil, desde Araçatuba até as barrancas do Rio Paraná, na década anterior. A cidade de Andradina, criada em 1937, se tornou pólo urbano de uma nova fronteira agrícola" (COSTA \& WONG, 1982, p.06).

Assim, comparando a evolução demográfica entre os anos de 1940 e 1950 dos municípios surgidos no começo do século XX com os nascidos no final da década de 1930 na sub-região de Andradina, temos o seguinte:

Tabela 3

Região de Araçatuba

População e Taxas Anuais de Crescimento Populacional por Sub-Região 1940-1950

\begin{tabular}{|c|c|c|c|}
\hline $\begin{array}{c}\text { SUB- } \\
\text { REGIÕES }\end{array}$ & 1940 & 1950 & $\begin{array}{c}\text { Taxa Anual de } \\
\text { Crescimento 1940-1950 }\end{array}$ \\
\hline Araçatuba & 265.622 & 313.680 & 1,66 \\
\hline Andradina & 22.852 & 110.147 & 15,73 \\
\hline Total & 288.474 & 423.827 & 3,85 \\
\hline Estado & $4,02 \%$ & $4,64 \%$ & 2,43 \\
\hline
\end{tabular}

Fonte: FUNDAÇÃO IBGE, Censos demográficos do Estado de São Paulo de 1940 a 1950 (COSTA \& WONG, 1982, p. 05-06). 
Com um aumento anual (3,45\%) na década de 1940 maior do que o verificado em todo o estado de São Paulo, a região como um todo possuía 4\% da população estadual. Imigrantes (principalmente japoneses) e migrantes (principalmente nordestinos) fundaram e povoaram os novos municípios entre Mirandópolis e Castilho (Falleiros, 1999). Entre os municípios mais antigos, alguns tiveram crescimentos anuais maiores que a média sub-regional no período 1940-1950: Auriflama (2,5 \%), Buritama (4,6 \%) e Araçatuba (3\%): esse último município, o maior da região, o único com mais de 50 mil habitantes, já figurava como pólo regional.

No ano de 1950, com uma ocupação predominantemente rural, a região de Araçatuba possuía 34 aglomerações - entre municípios e distritos de paz - que distribuídas por classes de população, apresentava a seguinte distribuição:

Tabela 4: Distribuição das Aglomerações Humanas na Região de Araçatuba Segundo Classes de População - (1950)

\begin{tabular}{|c|c|}
\hline Classes de População & 1950 \\
\hline Até 5 mil & 8 \\
\hline De 5 a 10 mil & 12 \\
\hline De 10 a 20 mil & 7 \\
\hline De 20 a 50 mil & 6 \\
\hline De 50 a 100 mil & 1 \\
\hline De 100 a 200 mil & - \\
\hline De 200 a 500 mil & - \\
\hline Mais de 500 mil & - \\
\hline
\end{tabular}

Fonte: FUNDAÇÃO IBGE, Censo demográfico do Estado de São Paulo de 1950. 
Requisitando de grande quantidade de mão-de-obra para os tratos culturais durante o ano todo, o algodão e o café - que teve uma vasta ocupação até a década de 1960, principalmente na sub-região de Andradina (Falleiros, 1999) - mantiveram a expansão demográfica na Noroeste Paulista direcionada à zona rural. Sendo o processo produtivo 'na lavoura' dos circuitos espaciais dessas culturas ainda pouquíssimo mecanizado, o trabalho realizado com técnicas manuais em elevada densidade, reproduzia na espacialidade regional a formatação de sistemas de objetos e ações característicos do regime de colonato.

O progresso da cotonicultura continuou em marcha acelerada até 1944. O quinquênio 1940/1944 pode ser considerado o período áureo do algodão em São Paulo, assinalado por suas maiores safras. A safra de 1944 constituiu o recorde absoluto no volume de produção. Já a safra de 1945, teve resultados desastrosos devido ao decurso desfavorável do tempo que naquele ano foi muito adverso. Contudo, foi o poderio norte-americano no controle internacional desse setor o que mais caracterizou a retração da cultura do algodão no estado de São Paulo. Pressionados pelo avolumar contínuo dos seus estoques de algodão e a grande colheita dos países produtores, os Estados Unidos se viram compelidos a adotar uma política agressiva de exportação, com a alegação de constituir o restabelecimento de sua participação histórica no setor. Isso gerou uma redução dos preços internacionais em 1944, o que inibiu as perspectivas futuras dos paulistas em relação a essa cultura.

Com a crise, na Noroeste, o que aconteceu foi uma redução do plantio nas áreas de formação de pastagens. Para abastecer a demanda do mercado interno, manteve-se em menor proporção a oferta da pluma e do caroço dos pequenos produtores às grandes empresas localizadas na região. 


\section{Capítulo 3}

\section{O Circuito Pecuário na Região de Araçatuba}

A nível mundial, o fim da $2^{\mathrm{a}}$ Guerra,

“... marca também o início de uma nova era dentro do percurso capitalista, com as perspectivas abertas pela revolução científicotécnica. Era o momento de lançar a semente de dominação do mundo pelas firmas multinacionais, preparando assim todos os espaços mundiais para uma nova aventura" (SANTOS \& SILVEIRA, 2001, p.47).

Essa nova fase, chamada de período técnico-científico, diferenciase das anteriores devido à intensa ligação da ciência na produção das técnicas. A partir de um aumento acelerado nos investimentos em pesquisa, a disseminação de novas técnicas deixa de ser uma atividade marginal no sistema produtivo e passa a centralizar a lógica de sua reprodução.

A nível nacional, sendo o Brasil um país subdesenvolvido industrializado, esse processo de interação só iria se efetivar trinta anos depois dos países desenvolvidos, ou seja, na década de 1970. Era ainda no Brasil um período de transição - do técnico ao técnico-científico -, onde em nosso território, a pesquisa científica começava a se estruturar, contudo de maneira limitada, em alguns institutos, quase exclusivamente no estado de São Paulo $^{26}$. Para termos uma idéia do disparate em relação ao novo paradigma hegemônico localizado nas regiões centrais do capitalismo, o território brasileiro, como o de todos os outros países da periferia do mundo, entra na década de 1950 sem possuir uma indústria de bens de capital estruturada. Para satisfazer as necessidades domésticas de consumo,

\footnotetext{
${ }^{26}$ Para visualizar essa polarização paulista no desenvolvimento científico brasileiro, em 1965, “o número de técnicos que trabalhavam nos cinco institutos responsáveis pelo programa de pesquisa do Ministério da Agricultura era, na verdade, menor que o daqueles que prestavam serviços ao Instituto Agronômico de Campinas, em São Paulo: 424 contra 547. Assim, o número de pesquisadores que atendiam ao restante do país, era, na realidade menor que o daqueles que trabalhavam apenas para o estado de São Paulo" (SCHUH, 1977, p. 288). O que se destaca em São Paulo, no início da década de 1960, são as cerca de 400 Casas da Lavoura distribuídas na maioria dos municípios do estado, onde técnicos agrícolas já auxiliavam os produtores de maneira mais próxima e regular (PAIVA, 1983).
} 
“... as indústrias podiam ser instaladas com uma tecnologia superada - não raro máquinas que haviam sido usadas antes em países industrializados mais avançados - buscando a substituição de importações" (SANTOS \& SILVEIRA, 2001, p.21).

No que se refere ao sistema técnico de transportes, mesmo com as ligações inter-regionais advindas com as ferrovias, existiam vazios territoriais que não sendo contemplados com as infra-estruturas de acesso fluido, viviam à margem da integração acentuada a partir dos anos 1930. Na busca de superar esse estrangulamento para expansão do mercado interno, antes de anexar ao sistema de engenharia nacional as lógicas do período técnico-científico, entre as décadas de 1950 e 1970, instalou-se sistemas de objetos potencializadores da fluidez territorial. A construção de rodovias federais, estaduais e municipais - a maioria de terra batida - por todo o território nacional junto à instalação de alguns setores industriais de bens duráveis - automobilístico e de eletrodomésticos - são reflexos da “cimentação” desse processo.

Segundo Paiva (1983), para a agricultura,

“... o tremendo aumento de tráfego de caminhões pelo Brasil trouxe uma melhoria sensivel de comercialização, do ponto de vista do produtor, pois este deixou de ficar na dependência de poucas firmas locais desejarem ou não adquirir e transportar o seu produto. Os pequenos proprietários de caminhões estão sempre prontos para substituir as firmas nessa função, tão logo as diferenças de preço o permitam. Eliminou-se assim uma das posições monopolistas que gozavam as firmas intermediárias” (PAIVA, 1983, p. 190).

Como vemos na tabela abaixo, de 1952 a 1965, a quantidade (em Km) de estradas de rodagem no país aumentou 165\%: 
Tabela 5

Brasil: Desenvolvimento da Rede de Estradas Federais, Estaduais e Municipais (Km): 1952-1965

\begin{tabular}{|c|l|l|l|l|}
\hline Ano & Federal & Estadual & Municipal & Total \\
\hline 1952 & 12.315 & 51.032 & 238.800 & 302.147 \\
\hline 1956 & 22.859 & 59.593 & 383.416 & 465.868 \\
\hline 1960 & 32.402 & 75.875 & 359.771 & 468.048 \\
\hline 1965 & 36.170 & 99.568 & 667.330 & 803.068 \\
\hline
\end{tabular}

Fonte: SMITH, G. W. “A Política Agrícola Brasileira, 1950-1967”. In Desenvolvimento da Agricultura: Estudos de Casos. Livraria Pioneira. São Paulo, 1983.

Aliado à maior produtividade da lavoura entre 1945-1956, obtida principalmente no estado de São Paulo, “como fruto do emprego de melhores técnicas agrícolas na forma de adubos, inseticidas, melhores sementes, culturas mais intensivas, etc ${ }^{27}$ (Paiva, 1983, p. 171), a grande expansão e o melhoramento da rede de estradas,

“... não apenas reduziu os custos diretos de transporte, mas também tornou possível a descentralização da comercialização de vários produtos alimentícios para longe dos centros comerciais mais favorecidos, como centros do sistema de estradas de ferro ou portos oceânicos (por exemplo São Paulo, Porto Alegre e Rio de Janeiro)" (Smith, 1983, p. 221).

Assim, nesse momento, podemos concluir que no Brasil, ao mesmo tempo, aumentava-se a densidade técnica no território das próteses garantidoras de uma maior integração nacional a partir da aceleração da fluidez dos fluxos intra-nacionais (com as estradas de rodagem), e ensaiavase, a partir de São Paulo, a internalização do paradigma moderno (técnicocientífico) já vigorante nos países centrais do mundo. Como observação desse momento, para a agricultura obter a maioria dos novos insumos e implementos, recorria-se à importação, pois não possuíamos uma indústria nacional ou centros de pesquisa suficientes produtores desses itens.

\footnotetext{
${ }^{27}$ Enquanto o país em sua totalidade possuía um trator para cada 469 hectares em 1966, São Paulo, no mesmo ano, mostrando sua condição de região mais adiantada explanava uma relação de 1 trator para 219 hectares (Smith, 1983).
} 


\section{1) A Hegemonização da Pecuária Bovina de Corte na Região de Araçatuba em Meados do Século XX}

Na Noroeste Paulista, nesse momento, com a crise da cotonicultura, a pecuária bovina se estabeleceu como a cultura com a funcionalidade hegemônica no uso do espaço geográfico regional. Em Monbeig (1998), vemos que "nos arredores imediatos de Araçatuba, desde 1939 podiam ser vistos casas em ruínas, pomares invadidos pelo mato e o gado pastando em velhos cafezais ou em antigos campos de algodão" (MONBEIG, 1998, p. 314). Esse abandono barateou o preço da terra e propiciou a especulação fundiária com a implantação da pecuária extensiva na região. Abriu-se espaço para um novo ciclo produtivo, que preenchido de início por alguns pecuaristas mineiros, estruturou uma rede de poder regional basilada por fortes vínculos a nível nacional e, principalmente, com o capital estrangeiro. Na política, por exemplo, essa elite pecuarista em formação, enquanto atora hegemônica direcionadora do uso do espaço geográfico regional, da década de 1940 em diante, elege seus

deputados e prefeitos, encaminhando sem empecilhos as atividades do poder público na região. E, assim como as atividades capitalistas anteriores que predominaram na apropriação do espaço geográfico regional, no circuito produtivo da pecuária de corte, a Noroeste Paulista continua a exercer sua função especializada de totalidade parcial do mundo em movimento.

Dentre os mineiros, as famílias Maia, Aguiar Ribeiro e Rodrigues da Cunha foram as primeiras a adquirir terras nas redondezas de Araçatuba. Para a região eles passaram a deslocar suas boiadas vindas de Minas Gerais, Mato Grosso e Goiás, com o objetivo de engordá-las antes do abate nos frigoríficos localizados nas proximidades da região metropolitana de São Paulo. Nessa locomoção, feita na maioria das vezes em caravanas, o gado perdia muito peso. Necessitava-se de um repouso antes do abate para a recuperação desses animais. Daí a idéia das invernadas nas terras momentaneamente baratas da Noroeste Paulista. 


\section{Foto 32: Boiadeiros e Boiada nos Arredores de Araçatuba em torno dos Anos 1940 - 1950}

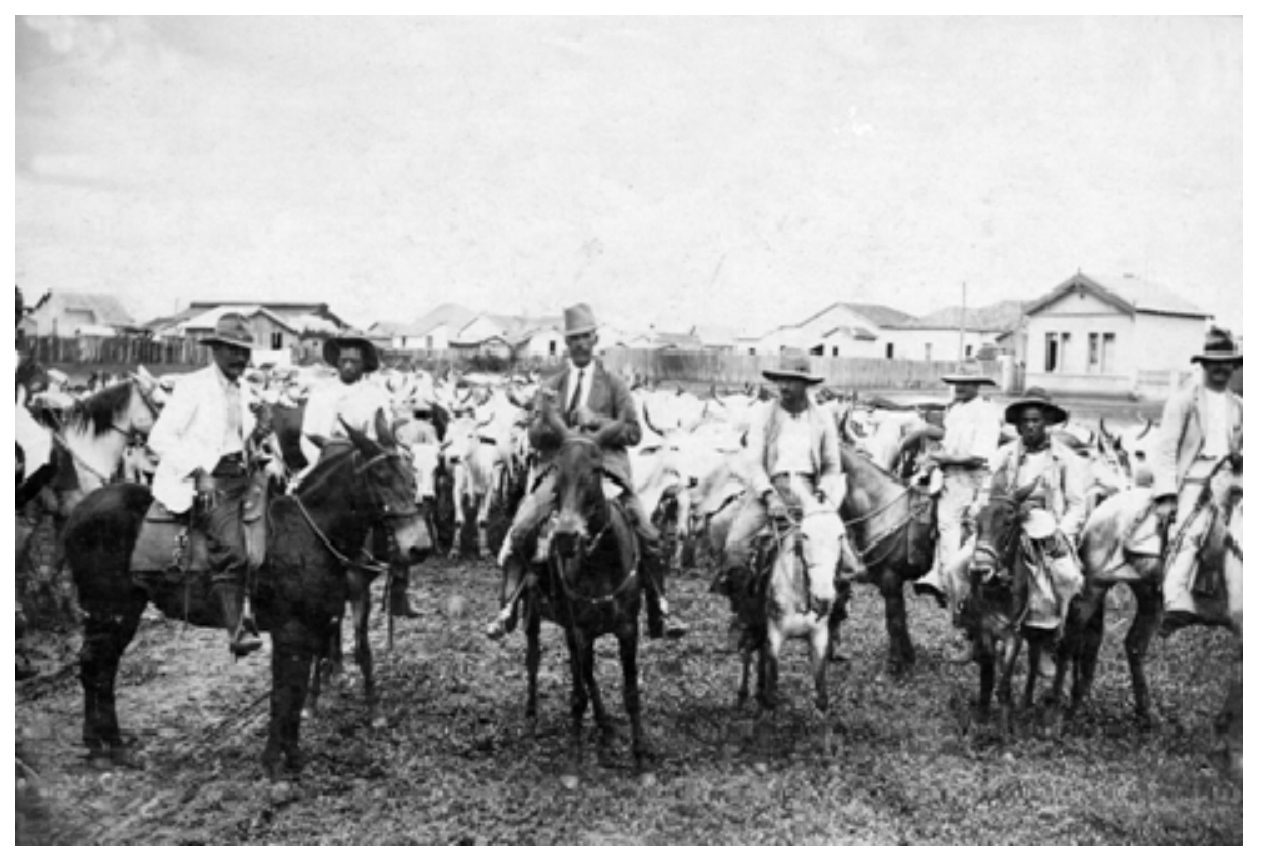

Fonte: Câmara Municipal de Araçatuba (sem data).

Após a engorda, o gado seguia de trem ou em caravanas pelas estradas de rodagem - como a Marechal Rondon, aberta entre 1940 e 1949 de Bauru à Araçatuba (Carvalho et al, 1992) - até aos abatedouros.

Sobre esse processo, Monbeig (1998) retrata:

"São Paulo aproximou-se bastante das regiões de criação, tornando-se possível uma associação com elas. Mas as distâncias continuam muito grandes, impossibilitando a entrega imediata aos matadouros e frigoríficos dos animais que chegam de Mato Grosso ou de Goiás. Eles chegam em território paulista magros e esgotados, depois de longos percursos e mesmo os que são transportados por estrada de ferro não se apresentam em melhor estado (...) É preciso restaurar o gado para obter um peso conveniente. Ora, quando este atravessa o Paraná ou o Rio Grande, vai encontrar pastagens verdes e terá tempo para repousar, antes da última etapa, que o conduzirá aos matadouros (...) Na franja pioneira, essas invernadas encontramse na posição geográfica mais favorável para receber as boiadas emagrecidas. As que se localizam junto à linha da Noroeste, desde os campos de Avanhandava até as pastagens de Castilho e Junqueira, recebem os comboios vindos por estrada de ferro ou as tropas vindas por Porto Independência. Depois da engorda, os animais cobrem facilmente o trajeto que os separa de Barretos. A Noroeste é a principal via de penetração do gado na zona pioneira (MONBEIG, 1998, p. 304-305)",28. 
Um sistema de crédito oficial mais acessível aos criadores de gado do que aos lavradores; fretes ferroviários mais vantajosos em relação às outras atividades agrícolas; mercado interno cativo com o crescimento da urbanização e aumento da demanda internacional por carne bovina foram motivos que levaram a pecuária à hegemonia na ocupação das terras do oeste paulista.

Especificando a região de Araçatuba nesse desenrolar, Monbeig (1998) novamente diz:

\begin{abstract}
"Os campos de Avanhadava e de Penápolis formam aí um primeiro núcleo de criação, que é completado pelas áreas conquistadas desde Bauru até Araçatuba, em prejuízo dos cafezais. O conjunto reúne 400.000 cabeças, das quais 154.000 no município de Araçatuba. É aí que começam, verdadeiramente, as invernadas de formação recente: umas estão na vertente do Tietê, com vastos domínios, como uma fazenda inglesa de 7.000 alqueires, perto de Aguapeí, ou como a fazenda Guanabara, em Andradina, que abriga 45.000 bois; outras estão na vertente Feio-Aguapeí. O espigão entre o Tietê e o Aguapeí está envolvido por um cinturão de invernadas ocupadas por perto de 300.000 animais" (MONBEIG, 1998, p. 307).
\end{abstract}

Para Pigatto (2001), esse alto volume de criação foi acentuado pela grande demanda do mercado internacional entre as Duas Guerras Mundiais. Maquinaria, trabalho especializado e tecnologia de refrigeração e processamento de carnes: o que era de mais moderno no setor de abate se importou para a construção de frigoríficos no Brasil. A maioria deles era de capitais britânicos e norte-americanos. E esse domínio externo do setor se perpetuou cada vez mais. Com o crescimento das plantas industriais, ocorreu um desequilíbrio entre a oferta e a demanda e os frigoríficos menos capitalizados sucumbiram à força dos grupos internacionais.

\footnotetext{
${ }^{28} \mathrm{O}$ frigorífico de Barretos foi o primeiro de grande porte instalado no país. A empresa iniciou os abates em 1913, com uma capacidade de abate de 400 bovinos e 400 suínos (PIGATTO, 2001).
} 
Sobre essa realidade, Monbeig (1998) explana:

\begin{abstract}
"Se o impulso inicial foi dado por Antônio Prado, quando fundou o frigorífico de Barretos, seriam as firmas inglesas Swift, Wilson e Armour que retomariam o caminho, depois da compra do frigorífico de Barretos e a fundação, durante a Primeira Guerra Mundial, de novas instalações, nos subúrbios da capital. Essas sociedades estrangeiras são detentoras de uma parte apreciável das invernadas. Estima-se em 1941 que elas possuíam 77.418 alqueires em propriedades, (...) A organização vertical foi levada mais longe ainda, no caso da Wilson, cuja base financeira é a mesma da Blue Star Line, empresa de que os navios freqüentam o Porto de Santos. Pode-se avaliar facilmente a força de uma organização tão completa. De resto, os frigoríficos não se contentam em possuir suas próprias invernadas e também as alugam de invernistas, sob contratos de dois anos, pagando proporcionalmente às cabeças de gado. (...) Como, praticamente, são os únicos compradores, exercem uma ação determinante sobre os preços e podem restringir ou aumentar as compras junto aos criadores independentes, em função do estado das suas próprias pastagens, ou de acordo com o rumo que desejam imprimir ao mercado de gado". (MONBEIG, 1998, p. 313314).
\end{abstract}

Durante a Segunda Guerra Mundial houve um aumento desordenado das exportações de carne bovina no Brasil. Esse fato acabou gerando insuficiência no abastecimento do mercado nacional. Com isso, o governo de Getúlio Vargas, de forma emergencial, através da Comissão de Financiamento da Produção (CFP) - órgão criado nos anos 1940, de apoio ao abastecimento de produtos agrícolas -, interviu no setor, reduzindo os preços e as exportações do produto. Em 1943, proibiram-se as exportações da carne bovina, passando seu preço a ser tabelado até 1951. (Pigatto, 2001).

Esse momento de desequilíbrio no comércio internacional possibilitou um rearranjo no mercado interno. Com a aceleração da urbanização/industrialização nos anos de 1950 no país, o elo da indústria direcionado à geração de uma maior fluidez no abastecimento dos mercados nacional e internacional teve sua produção aumentada. Reflexo disso, nas palavras de Pigatto (2001):

“... levou a alterações no panorama da indústria frigorífica, com o crescimento dos frigoríficos de médio porte, dotados de tecnologia de refrigeração e equipamentos mais eficientes, favorecidos também pelas reduzidas barreiras à entrada nos segmentos que apenas realizam o abate" (PIGATTO, 2001, p. 41). 
Para criar condições de estruturação do setor nesse período, o governo federal, pelo Plano de Metas, desenvolvido no mandato de Juscelino Kubitsheck, financiou via BNDE (Banco Nacional de Desenvolvimento Econômico) a construção de frigoríficos no país. Na década de 1950, frutos dessa política pública, na Noroeste Paulista surgiram duas grandes indústrias de abate de gado: o Mouran ${ }^{29}$, em Andradina e o TMaia, em Araçatuba, que, como inovações anexadas ao espaço geográfico, deram outro peso na balança das relações regionais com a totalidade do setor. Grande parte do gado em engorda localizado no entorno de Araçatuba passa a ser abatido nesses dois frigoríficos, que complementados aos pequenos abatedouros rudimentares construídos "com inspeção municipal ou sem nenhuma inspeção” (Páez, 1975, p. 143) em quase todos os municípios da região e do estado, diminuem o percentual de abate das empresas localizadas na Grande São Paulo ${ }^{30}$. Com essas anexações, e constituindo-se na região com o maior rebanho do estado (20\% do total), Araçatuba passa a exercer influência fundamental no preço do boi gordo em todas as praças do país: populariza-se como a capital do boi gordo.

\footnotetext{
${ }^{29}$ Moura Andrade, dono do frigorífico e das maiores invernadas do período, era apelidado como "o rei do gado".

${ }^{30}$ Nesse momento, com o surgimento desses e de outros frigoríficos, o estado de São Paulo concentrou a expansão do setor. No chamado Brasil-Central - MT, MS, ES, RJ, MG e PR-, em meados de 1960, São Paulo realizava mais da metade dos abates nacionais.
} 


\section{Fotos 33 e 34: Frigorífico TMaia em Araçatuba}

em torno dos Anos 1960
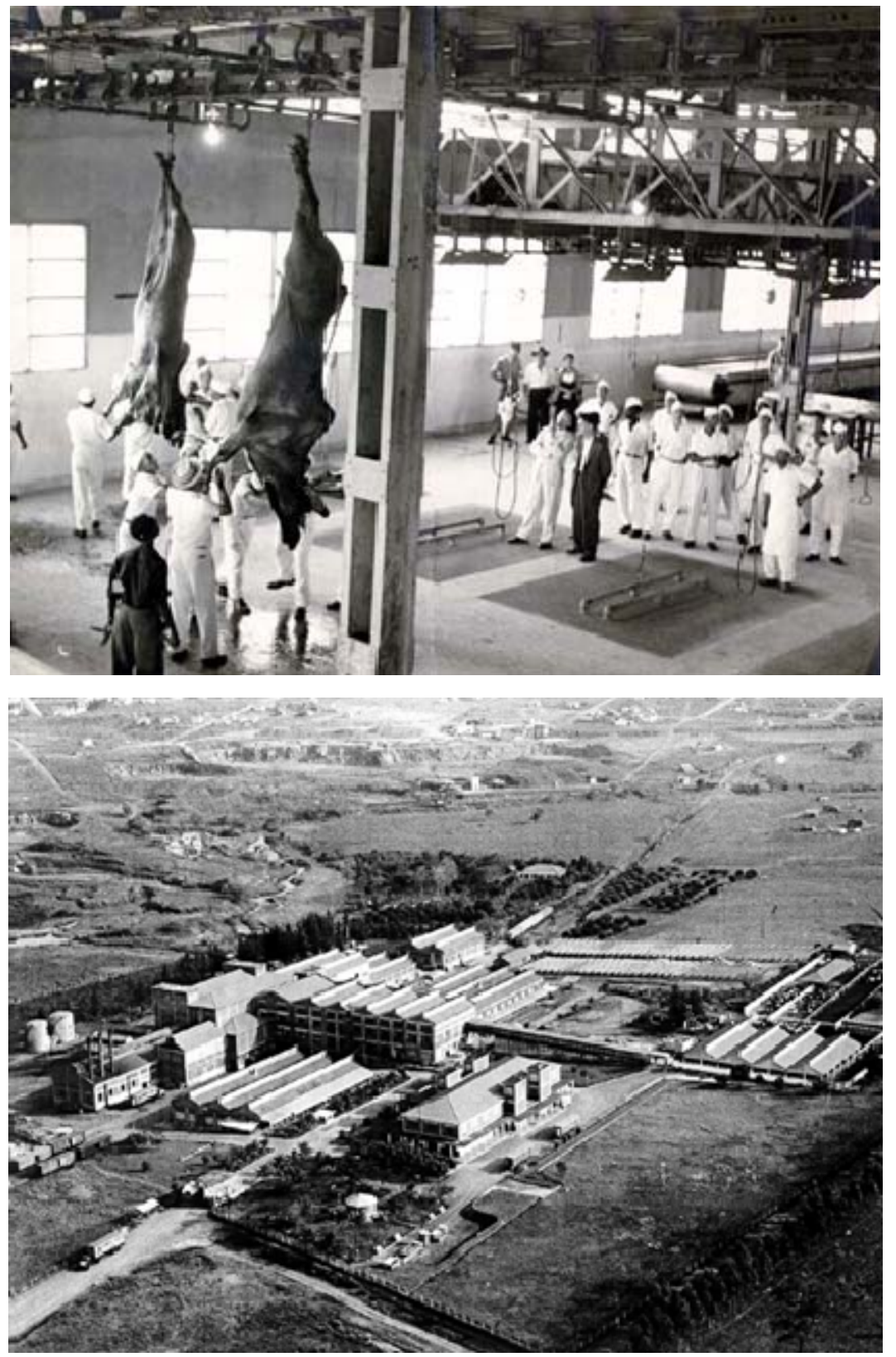

Fonte: Câmara Municipal de Araçatuba (sem data).

Dos trilhos da ferrovia, em vagões próprios dessas empresas de abate, a maior parte da carne obtida se direcionava aos consumidores de outras regiões brasileiras - principalmente da Grande São Paulo - e do mundo (em pequena proporção, devido às taxações governamentais às exportações de carne bovina, o que privilegiava o abastecimento do mercado interno). 
Fotos 35 e 36: Vagões Próprios do TMaia Transportadores de Carne
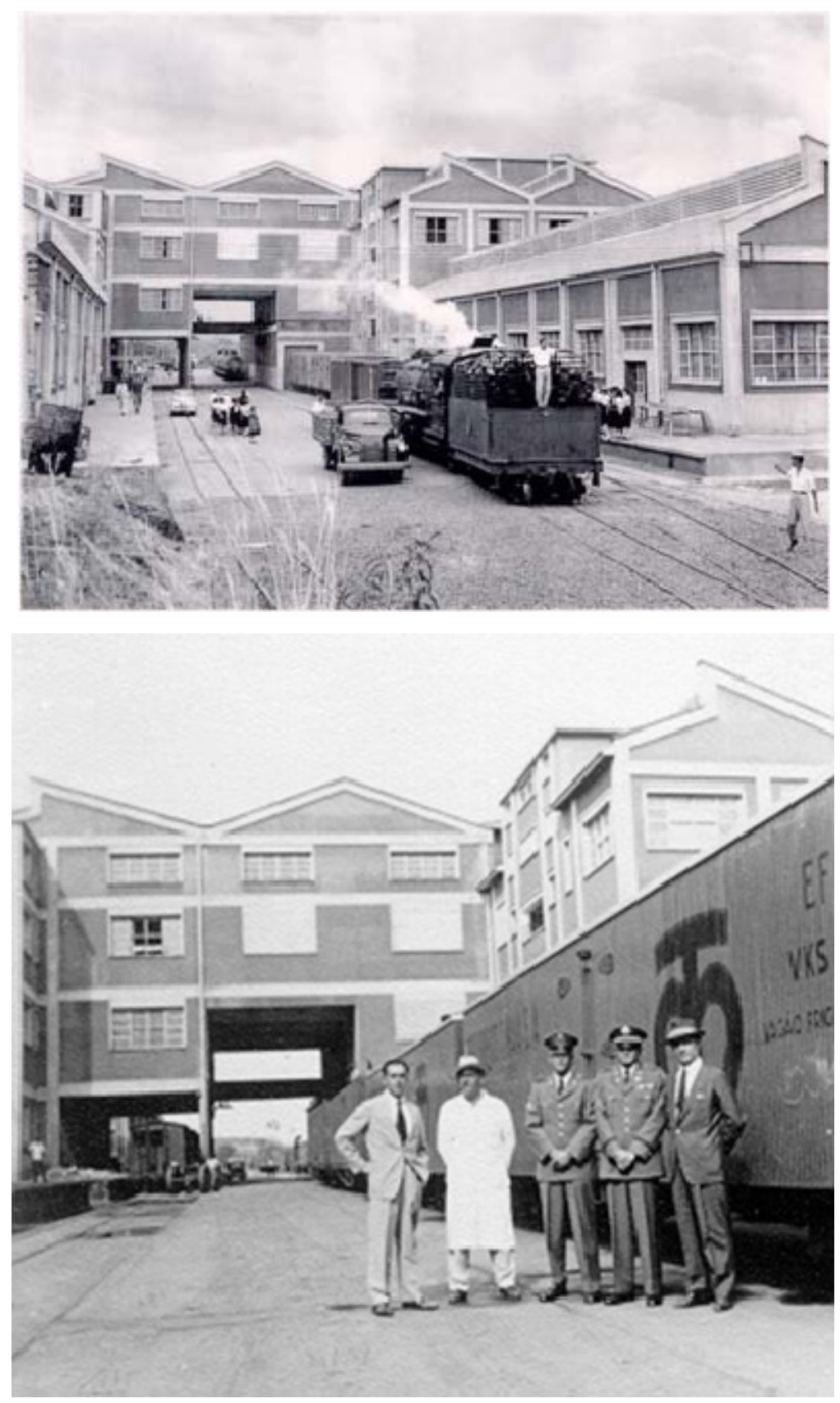

Fonte: Câmara Municipal de Araçatuba (sem data). 


\section{2) Algumas Implicações Sócio-Espaciais da Expansão da Pecuária Bovina de Corte na Região de Araçatuba}

Em termos de produtividade agrícola, diferente das agroindústrias (frigoríficos), que se aprimoravam no uso de importadas técnicas modernas em suas atividades (Pinheiro \& Bodstein, 1997), no campo, tínhamos um sub-aproveitamento das áreas (Costa \& Wong, 1982). Com um ainda pequeno investimento em pesquisa que possibilitasse a melhoria das pastagens, a principal funcionalidade aparentada com a posse e o uso das terras na Noroeste Paulista pela pecuária bovina de corte - onde 40\% das áreas de pastagens se constituíam de propriedades acima de 1.500 ha (Toyama \& Martin \& Tachizawa, 1976) - era a especulação fundiária (Pinheiro, 1980; Sayad, 1977). À espera da valorização de suas terras e de atividades com melhores custos de oportunidade, os produtores mantinham um pastoreio super-extensivo, com a presença de áreas apresentando aproximadamente 1 boi para cada 2 hectares (Igreja, 1973).

Reflexo dessa sub-ocupação, adicionada ao fato de que a pecuária é uma atividade que requer pouca mão-de-obra, no decorrer da década de 1950 o crescimento populacional da região começava a desacelerar. Sem mercado para vender o algodão e o café, parte dos proprietários rurais da sub-região de Andradina, como já se vinha fazendo nas proximidades de Araçatuba, começa a liberar suas terras para o pastoreio do gado. Necessitando de bem menos trabalhadores, desfaz-se da grande maioria dos colonos antes usados nos tratos da lavoura. Não possuindo emprego suficiente nos setores industrial e de serviços nas áreas urbanas para esses desempregados do campo, a migração para outras regiões do estado e do país foi a saída encontrada por muitos. 
Tabela 6

Região de Araçatuba

População e Taxas Anuais de Crescimento Populacional por Sub-Região

1950-1960

\begin{tabular}{|c|c|c|c|}
\hline $\begin{array}{c}\text { SUB- } \\
\text { REGIÕES }\end{array}$ & 1950 & 1960 & $\begin{array}{c}\text { Taxa Anual de } \\
\text { Crescimento 1950-1960 } \\
\text { (\%) }\end{array}$ \\
\hline Araçatuba & 313.680 & 350.193 & 1,10 \\
\hline Andradina & 110.147 & 131.613 & 1,78 \\
\hline Total & 423.827 & 481.806 & 1,28 \\
\hline \% do Estado & 4,64 & 3,76 & 3,39 \\
\hline
\end{tabular}

Fonte: FUNDAÇÃO IBGE, Censos demográficos do Estado de São Paulo de 1950 a 1960 (COSTA \& WONG, 1982, p. 05-06).

Como se pode observar, entre 1950 e 1960, o crescimento populacional da região, de forma diferente do decênio anterior, foi menor do que o observado no estado de São Paulo. Assim, sua representatividade na população total da província caiu de 4,64 \% para 3,76 \%.

Tabela 7

Região de Araçatuba

População e Taxas Anuais de Crescimento Populacional por Sub-Região 1960-1970

\begin{tabular}{|c|c|c|c|}
\hline $\begin{array}{c}\text { SUB- } \\
\text { REGIÕES }\end{array}$ & 1960 & 1970 & $\begin{array}{c}\text { Taxa Anual de } \\
\text { Crescimento 1960-1970 } \\
\text { (\%) }\end{array}$ \\
\hline Araçatuba & 350.193 & 358.842 & 0,24 \\
\hline Andradina & 131.613 & 173.707 & 2,78 \\
\hline Total & 481.806 & 532.549 & 1,00 \\
\hline \% do Estado & 3,76 & 3,00 & 3,27 \\
\hline
\end{tabular}

Fonte: FUNDAÇÃO IBGE, Censos demográficos do Estado de São Paulo de 1960 a 1970 (COSTA \& WONG, 1982, p. 05-06). 
Durante a década de 1960, o esvaziamento da população continua.

Devido à destruição dos resquícios de cafezais que ainda existiam, mais braços de colonos deixam de ser requisitados, acentuando o percentual de pastagens para uma ocupação de $85 \%$ do espaço geográfico regional no final da década, ou seja, 1.540.617 hectares (Camargo, 1983), com um rebanho de 1.373 .000 cabeças de gado $^{31}$ (Espírito Santo, 2005) ${ }^{32}$.

Crescendo a taxas anuais (1,0 \% ao ano), duas vezes menores do que o estado (3,0 \% ao ano) como um todo, Araçatuba e sua hinterlândia perderam 0,76 \% no percentual da população estadual. Passou de 3,76 \% em 1960 para 3,0 \% em 1970. Mesmo com os incentivos estatais gerados pela construção do Complexo Hidrelétrico de Urubupungá nesses anos 60 ter atraído para a RG de Andradina milhares de trabalhadores que avolumaram a densidade populacional de municípios como Andradina e Pereira Barreto (Hespanhol, 1996), dos 37 municípios existentes em 1970 na RA de Araçatuba, 18 tiveram seu número de habitantes diminuídos na comparação com 1940 e $1950^{33}$.

\begin{abstract}
${ }^{31}$ Toda essa ocupação da pecuária não se realiza somente com o gado de corte. Dados obtidos em Vasconcelos (1982) nos mostram que o rebanho de leite na pecuária regional correspondia a 15\% de todo o rebanho: isso significava 232.000 cabeças de gado leiteiro em 1973, com uma produtividade de 689 litros por vaca/ano (Espírito Santo, 2005). Essa fatia da ocupação das pastagens pela pecuária leiteira esteve ligada com a anexação de uma unidade da companhia multinacional Nestlé de alimentos para o beneficiamento de leite na região no início da década de 1960. Segundo Espírito Santo (2005), "A empresa foi atraída pela grande oferta de matéria-prima com baixos custos de produção e possibilidades de expansão da produção. Também a pecuária leiteira sofre grande expansão, principalmente entre os pequenos proprietários, que se adaptam aos métodos do novo comprador. Logo, a Nestlé, com suporte técnico, grande escala de compra, processamento e instalação de vários postos de recebimento por toda a região, domina o mercado, e impõe suas formas e regras para a compra do leite" (ESPIRITO SANTO, 2005, p. 128). Rego (1990, p. 36) relata que na mesma época "outros laticínios, também se instalam em Araçatuba, destacando-se o Alves Azevedo, que se volta principalmente, para a pausterização do leite". A Nestlé no início produzia leite em pó, depois diversificou sua produção, com o creme de leite e o leite desnatado.
\end{abstract}

\footnotetext{
${ }^{32}$ Uma cultura que passou a ser destaque na década de 1960 na região de Araçatuba foi a do tomate após a instalação da indústria de processamento Paoletti. Segundo Espírito Santo (2005), na região “... as lavouras tiveram uma perda importante em termos de área, ou seja, cerca de 100 mil ha de áreas ocupadas por lavouras no Censo de 1960 deixaram de existir no levantamento de 1975. Como na categoria lavouras estão incluídas culturas temporárias e permanentes e, conforme dados de área plantada por cultura do IBGE no período em estudo, constata-se que as culturas que perderam área foram o café, o algodão e o feijão. (...). Arroz e o amendoim (...) permaneceram estáveis, com pouca oscilação na área ocupada no período. Já o milho aumentou sua participação na área total das lavouras de 12,6\% para 32,2\%, e, a cana-de-açúcar com participação na área com lavouras praticamente nula no Censo de 1960, passou para 2,4\% em 1975" (ESPIRITO SANTO, 2005, p. 99).
}

33 Alguns municípios surgidos em meados de 1940 apresentaram dados a partir de 1950, ano no qual usamos para comparação. Para os municípios surgidos em meados de 1950 usamos os dados de 1960. Nesses casos tivemos o cuidado de analisar as divisões administrativas como geradoras de perdas 
Trinta deles, menores de 20 mil habitantes, viviam diretamente dependentes da economia do café ou do algodão. Clementina, por exemplo, em 1960, tinha 10.103 habitantes, sendo que 8.668 na zona rural e 1.435 na zona urbana. Em 1970, viu sua população total cair para 5.247!

Tabela 8

Município de Clementina

População Urbana, Rural e Total

1950-1970

\begin{tabular}{|l|c|c|c|}
\hline Ano & População Urbana & População Rural & Total \\
\hline 1950 & 823 & 12.110 & 12.933 \\
\hline 1960 & 1.435 & 8.668 & 10.103 \\
\hline 1970 & 1.520 & 3.727 & 5.247 \\
\hline
\end{tabular}

Fonte: FUNDAÇÃO IBGE, Censos demográficos do Estado de São Paulo de 1950, 1960 e 1970 (REGO, 1990, p. 98).

O significativo dessa análise, como se pode ver na tabela acima, foi que a diminuição aconteceu entre os colonos, na zona rural. Na área urbana, o número de moradores se manteve quase inalterado, subindo aproximadamente $5 \%$. Então, perguntamos: para onde se deslocou o colonato expulso do campo? ${ }^{34}$ Para Costa \& Wong (1982), observando-se os dados do crescimento vegetativo e do fluxo migratório na região de Araçatuba, conclui-se que parte considerável desses trabalhadores rurais emigrou. Segundo as autoras,

populacionais, porém sem incluí-las no resultado do rearranjo estrutural advindo com a expansão da pecuária bovina.

${ }^{34}$ A saída dos colonos e a opção pela pecuária, provavelmente tenha se acentuado no início da década de 1960 pela mudança na legislação trabalhista, a partir da vigência do ETR (Estatuto do Trabalhador Rural). 
“... é sabido que a passagem da lavoura para a pecuária é um processo liberador de mão-de-obra. Por outro lado, na região não se desenvolveram grandes centros urbanos, com a capacidade de absorção de trabalho na indústria e nos serviços. (...) Assim, na ausência de empregos alternativos na região, a população vem sendo forçada a procurar colocação, em números crescentes, em outras regiões do Estado ou fora dele. Assim se explica que a região se tenha constituído, depois de 1950, em região expulsora de população" (COSTA \& WONG, 1982, p. 17-19).

Esse reordenamento da ocupação do espaço geográfico, também acontecido pela introdução de novas técnicas como o trator e implementos em substituição às atividades manuais, ocasionou reflexos na divisão social e territorial do trabalho. O campo deixa de ser hegemônico como lócus da maioria da mão-de-obra regional, perdendo espaço para as atividades industriais e de serviços. Assim, a região se urbaniza, entrando 1970 com 57,5\% da população morando nas cidades.

Tabela 9

Região de Araçatuba

Distribuição Setorial do Emprego (\%)

1950-1970

\begin{tabular}{|c|c|c|}
\hline SETOR & 1950 & 1970 \\
\hline Agricultura & 76,71 & 45,40 \\
\hline Indústria & 6,71 & 18,54 \\
\hline Outros & 16,57 & 36,06 \\
\hline TOTAL & 100,00 & 100,00 \\
\hline
\end{tabular}

Fonte: FUNDAÇÃO IBGE, Censos demográficos do Estado de São Paulo de 1950 a 1970 (COSTA \& WONG, 1982, p. 20).

Tornando-se predominantemente urbana (57,9\%), principalmente nos municípios maiores, parte dos colonos da região se deslocaram para as áreas urbanas de Araçatuba, Andradina e Pereira Barreto. Araçatuba, por exemplo, concretizando-se como capital regional, aumentou sua população de 59.452 em 1950 para 108.512 habitantes em 1970: com 80,07\% de taxa 
de urbanização ${ }^{35}$, esse município firmou-se na situação de pólo dentro da hierarquia urbana regional. Naquele momento, na Noroeste,

"Araçatuba é a única cidade, além disso, onde aparece comércio atacadista e onde o setor como um todo (comércio varejista e atacadista) tem expressão no conjunto das atividades econômicas" (REGO, 1990, p. 105).

Tabela 10: Distribuição das Aglomerações Humanas na Região de Araçatuba Segundo Classes de População (1960-1970)

\begin{tabular}{|c|c|c|}
\hline Classes de População & 1960 & 1970 \\
\hline Até 5 mil & 8 & 12 \\
\hline De 5 a 10 mil & 15 & 12 \\
\hline De 10 a 20 mil & 7 & 6 \\
\hline De 20 a 50 mil & 6 & 4 \\
\hline De 50 a 100 mil & 1 & 2 \\
\hline De 100 a 200 mil & - & - \\
\hline De 200 a 500 mil & - & - \\
\hline Mais de 500 mil & - & 1 \\
\hline
\end{tabular}

Fonte: FUNDAÇÃO IBGE, Censos demográficos do Estado de São Paulo de 1960 e 1970.

A presença da COBRAC (Cooperativa Agropecuária do Brasil Central) ${ }^{36}$, das agências bancárias, das sedes das associações de classe e a abertura e melhoria das estradas - como a pavimentação da Rodovia Marechal Rondon $^{37}$ - que convergiam para Araçatuba, são algumas provas da centralidade que esse município cada vez mais passava a exercer como eixo de desenvolvimento regional polarizado (Hernández, 1998).

\footnotetext{
${ }^{35}$ A taxa média do estado de São Paulo em 1970 era de 80,3 \%.

${ }^{36}$ Fundada em 1965.

37 Ocorrida em 1961, a pavimentação de Lins até a barranca do Rio Paraná, potencializou fluxos mais rápidos entre Araçatuba, as municipalidades de seu entorno, a região metropolitana de São Paulo e o porto de Santos.
} 
(1997) retrata:

\begin{abstract}
"Cremos que dois fatores colaboraram para esse aumento populacional. O mais importante deles são as conseqüências da pecuária. Com ela, Araçatuba tornou-se uma capital de mercado bovino. O movimento de industrialização da carne, com o frigorífico que se instalara na década anterior; a implantação de outra grande indústria - a Nestlé, que para cá veio nesta década, primeiramente atraída pela prolífica fonte de leite bovino; a criação de um fortíssimo sindicato de pecuaristas, o SIRAN - Sindicato Rural da Alta Noroeste; e a organização e o estabelecimento de providencial cooperativa comercial para os pecuaristas araçatubenses e regionais. $O$ outro ponderável fator de incrementação populacional foi a instalação de várias escolas; mormente a estratificação funcional da FOA - Faculdade Odontológica de Araçatuba, a criação da Instituição Toledo de Ensino - com a Faculdade de Filosofia, Ciências e Letras de Araçatuba, bem como a Associação de Ensino Marechal Cândido Rondon - com as Faculdades de Administração de Empresas e de Ciências Contábeis. Com esses cursos superiores, centenas de alunos para Araçatuba se mudaram; famílias de apoio de estudantes, de funcionários, de professores - aqui se instalaram; repúblicas estudantis foram criadas. Restaurantes, bares, livrarias, bibliotecas, lojas especializadas - tudo trouxe incremento demográfico" (PINHEIRO \& BODSTEIN, 1997, p. 327328).
\end{abstract}

A partir dessas transformações profundas instaladas - que são novos objetos geográficos -, a centralidade do conhecimento e da informação regionalmente polarizada no município de Araçatuba, sedimentou cada vez mais a atração dos fluxos de sua hinterlândia para si.

Para o restante dos municípios, prioritariamente os pequenos, fundados e mantidos no período cafeeiro, destaca-se a preocupação de Costa \& Wong (1982):

“... poder-se-ia dizer que o ponto que merece maior destaque, na análise da situação em Araçatuba, é o progressivo esvaziamento populacional da região. Este é de tal gravidade que, se não se tomarem medidas excepcionais para a fixação da população, alguns centros povoados correrão o risco de desaparecer, numa região que já é precariamente ocupada. Um exercício teórico, que extrapola no tempo, as taxas negativas de alguns municípios, conduz necessariamente a este tipo de conclusão" (COSTA \& WONG, 1982, p. 28). 


\section{Capítulo 4}

\section{Modernização do Território Brasileiro:}

\section{A Agricultura e Algumas Implicações na Região de Araçatuba}

Após a Segunda Guerra Mundial, a integração do território brasileiro se viabiliza. Até meados da década de 1960,

“... quando as estradas de ferro até então desconectadas na maior parte do país, são interligadas, constroem-se as estradas de rodagem, pondo em contato as diversas regiões entre elas e com a região polar do País, empreende-se um ousado programa de investimentos em infra-estruturas. Ainda uma vez, uma nova materialidade superpõe novos sistemas de engenharia aos já existentes, oferecendo as condições técnicas gerais que iriam viabilizar o processo de substituição de importações para o qual todo um arsenal financeiro, fiscal, monetário, serviria como base das relações sociais (incluído o consumo aumentado) que iriam permitir mais uma decolagem" (SANTOS, 1994b).

Assim, em meados da década de 1960, impulsionado pelo movimento militar no poder, inicia-se uma intensificação da conexão do país ao processo de internacionalização que se acentuava naquele momento. Com uma crise de liquidez gerada pelo acúmulo de capitais em seus mercados, os países líderes do sistema capitalista vêem-se numa pressão para transferir esses capitais a outros mercados. Dessa maneira,

\footnotetext{
"A conquista de mercados financeiros na periferia possibilitou, sobretudo, um retorno à escassez e, com ela, a revalorização das divisas. O resultado desse ato de império foi que os países do Terceiro Mundo se endividaram em grande escala e, assim, absorveram o dinheiro que sobejava no sistema" (SILVEIRA, 1999, p. 96).
}

No Brasil, como em grande parte da América Latina, investimentos nunca antes vistos propiciaram a instalação de filiais de empresas estrangeiras em diversos setores. Pólos e complexos industriais são implantados em várias regiões do país. Novas associações empresariais, redes financeiras e obras públicas expandem a especialização de lugares. 
São eventos que despontam anexando novos conteúdos ao território nacional.

A serviço do sistema produtivo, além desses modernos novos objetos importados para gerar a fluidez desejada pelos capitais forâneos, internalizou-se no território nacional, na década de 1970, a “invenção do método de invenção" (SANTOS, 2002, p. 177). Com maior densidade no Centro-Sul do país, e em São Paulo principalmente, várias universidades, centros e institutos públicos de pesquisas foram implementados para atender as demandas por inovações nas cadeias produtivas. Sob a égide do mercado - igual aos países do centro do sistema -, as técnicas passaram a ser desenvolvidas massivamente em laboratórios científicos. Ampliou-se a divisão social, técnica e territorial do trabalho, tornando-se a intencionalidade do trabalho científico o paradigma para a modernização do território. Adentra o Brasil no período técnico-científico (SANTOS \& SILVEIRA, 2001).

No setor agrícola, programas e fundos de financiamento público foram criados objetivando sua modernização. A Embrapa (para todas as culturas em geral) e o Planalsucar (para a cultura canavieira) foram duas das principais instituições de pesquisa que, surgidas na década de 1970, propiciaram a internalização e expansão do período técnico-científico nacional. Complexos agroindustriais constituíram uma nova configuração econômica e sócio-espacial das diversas regiões brasileiras, levando a fronteira agrícola para a Amazônia. Os circuitos espaciais de produção se diversificaram, acentuando a informalidade advinda com a terciarização da economia. Os círculos de cooperação tornaram-se cada vez mais internacionais.

Nesse processo, o interior do estado de São Paulo é uma das principais áreas escolhidas para a realização dos fartos investimentos privados e estatais. Com uma vasta legislação estadual restritiva ao uso e ocupação industrial da região metropolitana da capital paulista a partir de 1975, interioriza-se o investimento da atividade industrial ${ }^{38}$. Da perspectiva

\footnotetext{
${ }^{38}$ Além do discurso ambiental, uma das variáveis mais importantes no desencadeamento do processo de interiorização da indústria que assumem destaque são as deseconomias de aglomeração, especialmente os custos do sistema de transporte de cargas e de passageiros, e os custos de infra-estrutura urbana. Os custos
} 
de investimentos e evolução das taxas de crescimento e participação percentual, a indústria do interior apresentou um grande avanço a partir dos anos 1970 e, sobretudo, a partir da década de 1980. Como critério para comparação, em 1970, a Região Metropolitana de São Paulo possuía 74,7\% do VTI (Valor de Transformação Industrial) do Estado; em 1980 cai para 62,9\%, declinando, em 1987, para 60\%. Num movimento contrário, a indústria do interior em 1970 respondia por 25,6\% do VTI estadual, chegando em 1980 a 37,1\%; alcançando em 1987, 40\% do VTI do Estado (SEADE, 1993). Para possibilitar esse notável desenvolvimento, o governo estadual investiu pesadamente na expansão de sua infra-estrutura rodoviária: iniciou a duplicação das principais rodovias longitudinais convergentes à metrópole e asfaltou várias transversais, beneficiando-se as regiões com predominância agropecuária e agroindustrial (NEGRI, 1996). 


\section{1) As Mudanças no Campo Brasileiro: \\ Constituição dos Complexos Agroindustriais}

A agricultura brasileira teve o seu período de maior transformação e estruturação durante o regime militar. Para Kageyama (1990), comparando-se os períodos pré e pós- 1965, “a modernização da agricultura brasileira no pós-guerra é basicamente pelo trator, que passa de substituto da força animal para substituto da mão do homem, da força de trabalho" (KAGEYAMA, 1990, p. 114). ${ }^{39}$

Sobre as limitações desse período 1945-1965, a mesma autora retrata que:

“... embora do lado da produção os determinantes da dinâmica da agricultura estivessem sendo deslocados para o mercado interno, do ponto de vista das transformações de sua base técnica ele ainda permanecia atrelado ao setor externo, pois sua modernização dependia da capacidade para importar máquinas e insumos” (KAGEYAMA, 1990, p.119).

Assim, para ela, é “a partir de meados dos anos 60 que o processo de modernização atinge uma fase mais avançada, a de industrialização da agricultura (KAGEYAMA, 1990, p. 121). Através de taxas de juros subsidiadas e de grandiosos recursos obtidos pelo Sistema Nacional de Crédito Rural (SNCR), criado em 1965, articulou-se a internalização ao território brasileiro de elos antes importados em diferentes setores agropecuários, constituindo os complexos agroindustriais no país. Esses elos internalizados são as indústrias de bens de capital: máquinas (tratores, colheitadeiras, plantadeiras, caminhões), implementos (arados, grades, etc), insumos (fertilizantes, defensivos) e as agroindústrias processadoras, que são construídas e passam a funcionar dentro do país. Com essa mudança possibilitada pela estruturação de uma indústria de base brasileira e estatal siderúrgica e metalúrgica -, rompem-se as barreiras e os limites impostos pelas importações. Onde antes nacionalmente se tinha na maioria das

\footnotetext{
39 Todos os tratores que entraram no campo brasileiro foram obtidos até 1960 via importação, pois não havia no território nacional nenhuma montadora.
} 
culturas agrícolas somente a produção da matéria-prima ${ }^{40}$, passa-se a ter todo um complexo: a "indústria para a agricultura” à montante e a agroindústria processadora à jusante do campo.

Acostumada com resultados práticos limitados, a estruturação da pesquisa e extensão rural feita pelo governo federal, com a criação no início da década de 1970 da EMBRAPA (Empresa Brasileira de Pesquisa Agropecuária) e da EMBRATER (Empresa Brasileira de Pesquisa Agropecuária), propiciou a cientifização da agricultura brasileira e a conseqüente expansão do meio técnico-científico pelo território nacional. Novos objetos técnicos (máquinas, implementos, sementes de novas variedades e insumos), enquanto "extraordinárias inovações científicotécnicas” (ELIAS, 1996, p.29) permitiram “... a introdução de certos cultivos em áreas antes inadequadas” (RAMOS, 2001, p. 21). Inovações físico-químicas, mecânicas e biológicas anexadas ao território brasileiro, configurou às práticas agrícolas um padrão parecido ao padrão industrial, onde as máquinas passaram a comandar o processo produtivo.

O crescimento da utilização desses novos objetos técnicos foi provocado por vários incentivos governamentais - créditos - realizados a partir de meados da década de 1960. Com suas taxas de juros abaixo da inflação, esses créditos foram assegurados via SNCR, que junto com a Reforma do Sistema Financeiro - articulada pelo Banco Central brasileiro estabeleceram o asseguramento da canalização para a agricultura de parte dos recursos captados pelos bancos (principalmente Banco do Brasil, via CREAI) no país e no exterior. Através da venda no mercado financeiro internacional de papéis da dívida pública, a partir de acordos com o FMI e o Banco Mundial, consegue-se grande parte do capital para a modernização do campo brasileiro e realização do chamado milagre econômico.

40 Algumas culturas ligadas ao mercado interno passavam por processamento antes de chegar aos consumidores. 
Com esse capital, o Estado brasileiro

“... subsidiou a compra de máquinas e equipamentos, insumos químicos; sementes melhoradas; custeou a produção, garantiu os preços mínimos, promoveu a eletrificação rural; construiu armazéns e silos para estocar a produção; subsidiou a exportação; isentou de impostos as indústrias nascentes associadas à agricultura moderna; promoveu o seguro agrícola etc” (ELIAS, 1996, p. 29-30).

Para a aquisição de certos insumos, criaram-se linhas especiais de financiamento, com remuneração e condições de pagamento ainda mais favorecidas $^{41}$.

Segundo Szmrecsányi \& Ramos (1997), esses créditos beneficiaram quase em sua totalidade os maiores produtores. Sobre essa realidade, Martine (1987) relatou que:

“... a participação no valor total dos financiamentos concedidos favoreceu, sobretudo as médias e grandes propriedades. Assim, por exemplo, os estabelecimentos de 100 a 1000 ha, que incluíam apenas $9,5 \%$ dos estabelecimentos em 1980, receberam 42,5\% do valor dos financiamentos concedidos; enquanto isso, os de 1000 a $10000 \mathrm{ha}$, com $0,9 \%$ dos estabelecimentos receberam 20,3\% do valor total" $(\text { MARTINE, } 1987 \text {, p. } 128)^{42}$.

${ }^{41}$ Porém, parte significativa dos investimentos feitos com esses créditos foi especulativa, na compra de terras. Segundo Pinheiro (1980), “... a falta de opção de investimento de parte da poupança em atividades produtivas...” (PINHEIRO, 1980, p. 172) levou esses grupos à compra de terras na busca de manterem 'reservas de valor' e obterem ganhos especulativos. Com a expansão do crédito subsidiado, aumenta a demanda por terras no período, elevando seus preços e tornando esses ganhos especulativos maiores do que os lucros do setor produtivo. Segundo Kageyama (1990), “... um desses capitais - o de terras - passa a ter papel de destaque nesse processo, ou seja, a propriedade da terra, ao permitir ganhos especulativos e ganhos de fundação, tornou-se um ativo alternativo para o grande capital. Esse processo, conhecido como 'territorialização do capital', pode ser ilustrado pelos dados seguintes: - considerando os maiores proprietários rurais em cada estado do país, destacam-se várias empresas industriais, financeiras e comerciais (...); seis das 10 primeiras empresas privadas nacionais em 1985 são também grandes proprietárias de terras (...) e duas das 10 primeiras empresas estrangeiras no país, controlam grandes extensões de terra, especialmente no pólo urbano-industrial do centrosul.” (KAGEYAMA, 1990, p.123).

42 Já os dados das pequenas propriedades, segundo Fischer (1992), permite constatar que “... apenas $10 \%$ dos estabelecimentos entre 0 e 10 ha de tamanho obtiveram financiamento em 1980. Entre as propriedades de 10 e 99 e de 100 a 1000 ha 32\% e 35\% delas, respectivamente, tiveram acesso a ele.” (FISCHER, 1992, p. 129). Para Pinheiro (1980), os bancos preferem, dentro da lógica financeira, fornecer o crédito rural subsidiado realizando grandes contratos com quem possa lhes oferecer uma garantia real. Assim, "beneficiam-se mais dessa política governamental os grandes proprietários agrícolas $e$ não os reais produtores agrícolas e/ou pequenos proprietários” (PINHEIRO, 1980, p. 168). 
Assim, a constituição dos Complexos Agroindustriais, efetivada de maneira concentradora na década de 1970, reordenou por completo a ocupação humana do espaço rural, principalmente no Sudeste e especificamente em São Paulo. A mecanização das lavouras possibilitada com o barateamento do capital via crédito agrícola, tornou praticamente inviável, para aqueles que se modernizavam via instalação de atividades tipicamente capitalistas, manterem trabalhadores permanentes nas fazendas. Com isso, o sistema de colonato - onde o tempo de não-trabalho era dedicado às culturas de subsistência, rebaixando o custo da força de trabalho - deixa de ser norma nas relações trabalhistas do campo brasileiro. O trabalhador volante, ex-colono residente no campo que agora mora na cidade e presta serviços específicos em parte do ano na zona rural, passa a ser o regime hegemônico de trabalho adotado na lavoura canavieira e em todas as culturas que se modernizam (Rossini,1988).

Assim, o tempo de não-trabalho nas relações de trabalho da agricultura moderna recairá sobre os trabalhadores, transformando-os em desempregados sazonais ou sub-empregados urbanos ${ }^{43}$. Acelera-se, assim, o processo de urbanização por todo o país.

Resultados desses investimentos na agricultura foram o grande crescimento da produtividade e a diminuição dos custos de produção na década de 1980. Fertilizantes, combustíveis, lubrificantes, defensivos, mãode-obra e terra apresentaram queda de preço.

Com a crise econômica dessa década, o crédito rural sofre restrições, com a permanência de subsídios em algumas atividades estratégicas (cana-de-açúcar, café e trigo) e o fortalecimento da política de preços mínimos em geral (Gasques \& Villa Verde, 1990). Chega-se nos

${ }^{43}$ Reforçando a mudança na base técnica como ação indutora do êxodo rural acelerado do período, em 1963 foi aprovado o Estatuto do Trabalhador Rural (ETR). Através dessa medida legal, o povo do campo passou a ter direitos trabalhistas como o povo das cidades: o salário mínimo, por exemplo. Dessa transição, Bertero (1981) explica que, “... desde 1961, com a tramitação no Congresso Nacional desse projeto de lei, cresceram as reivindicações trabalhistas no meio rural, as quais induziram usineiros e fazendeiros à dispensa em massa de seus trabalhadores rurais" (BERTERO, 1991, p. 36). Efetiva-se a crise no regime de colonato, pois não se poderia mais descontar parte do salário monetário do trabalhador que morava na terra do proprietário pelo pagamento em espécie obtido com o usufruto da lavoura de subsistência. Tudo isso acarretou a transformação dos colonos em trabalhadores assalariados temporários, levando-os a habitar a periferia das cidades. 
anos 1990, e o Brasil se apresenta com uma infra-estrutura no setor agrícola que possibilitará a competitividade em várias culturas agrícolas a partir da abertura comercial realizada desde então.

\section{2) Algumas Mudanças na Pecuária de Corte}

\section{na Região de Araçatuba nos Anos 1970}

O oeste paulista, de maneira geral, e a região de Araçatuba, especificamente, adentraram a década de 1970 tendo a bovinocultura como principal atividade econômica. Segundo Espírito Santo (2005), em 1975, as pastagens ocupavam $81,3 \%$ e as lavouras $14 \%$ da área agrícola dos estabelecimentos rurais na região araçatubense ${ }^{44}$. Isso a colocava como a possuidora do maior rebanho bovino de corte do estado de São Paulo.

Dentre as inovações técnicas inseridas nesse novo momento - que é o da modernização da agropecuária entendido como período técnicocientífico - coube em parte ao setor privado, através da ação do grupo Vicente Rodrigues (VR), a introdução da coleta e seleção de sêmen para melhoramento genético dos nelores zebuínos na região de Araçatuba. Tendo como referência o importado reprodutor indiano Kavardi - tetracampeão de performance estética e reprodutiva na Índia e Supercampeão da Ásia - , em 1968, na Fazenda Santa Cecília, e posteriormente na Chácara Zebulândia, em 1972, o grupo VR constituiu no oeste paulista, tendo Araçatuba como centralidade $^{45}$, um pólo de melhoramento genético e precisão de produtividade da pecuária bovina regional, nacional e internacional.

\footnotetext{
${ }^{44}$ Segundo Vasconcelos (1992), as lavouras em 1960 ocupavam ainda 1/3 das áreas regionais. Essa diminuição relativa para 1970 mostra o processo acentuado de hegemonização da pecuária na região no intervalo dessa década.

${ }^{45}$ A Chácara Zebulândia fica na entrada de Araçatuba, às margens da fluída Rodovia Marechal Rondon.
} 
Fotos 37 e 38: Kavardi Embalsamado

no Museu da Chácara Zebulândia, em Araçatuba
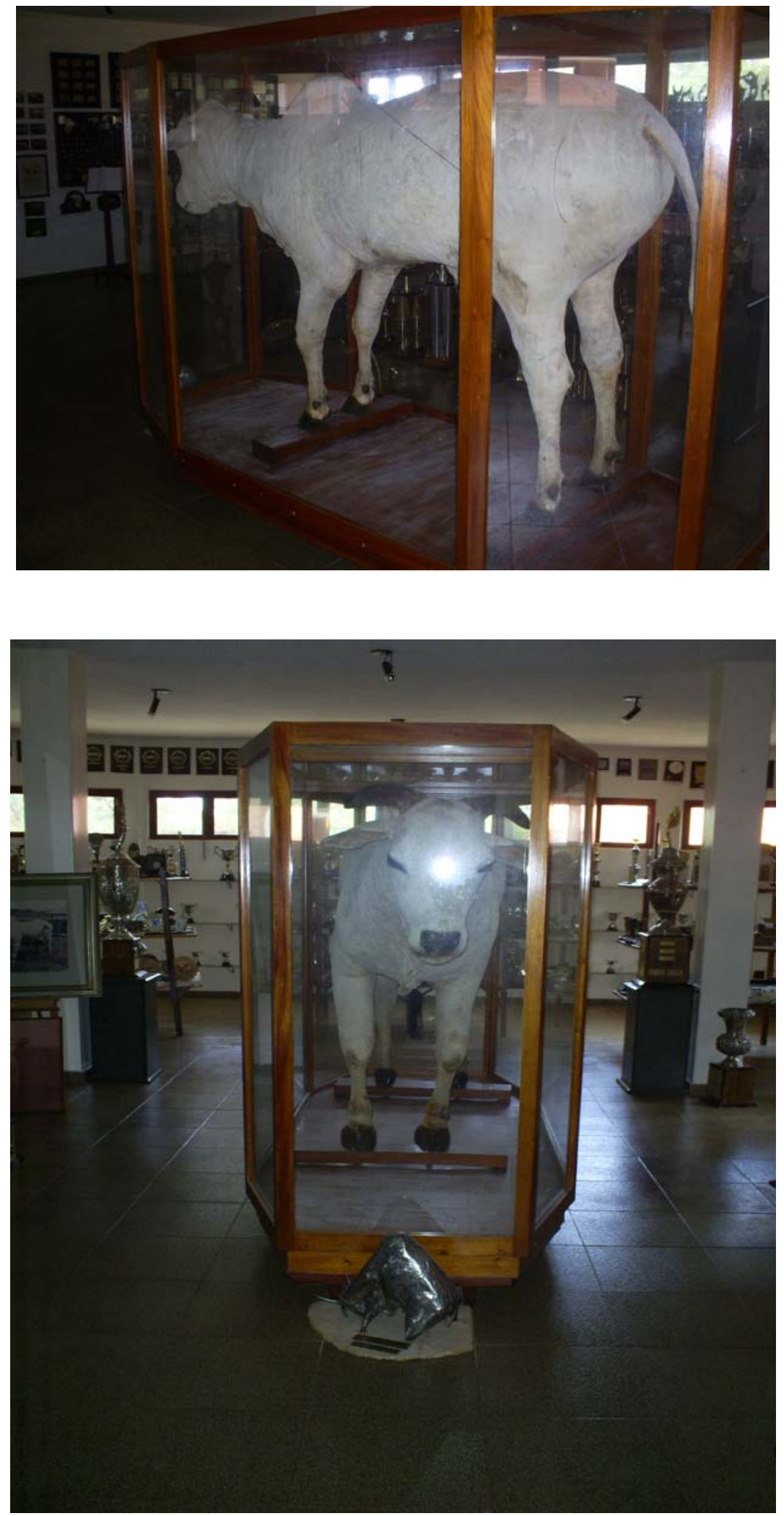

Fonte: Bini, Outubro, 2007. 
Tabela 11

Número e Percentual de Bovinos de Corte por Divisão Regional Agrícola do Estado de São Paulo, 1973.

\begin{tabular}{|l|l|l|}
\hline DIRA & Número de Bovinos & \% do estado \\
\hline Araçatuba & $\mathbf{1 . 2 4 7 . 0 6 8}$ & $\mathbf{1 9 , 9}$ \\
\hline Pres. Prudente & 1.199 .556 & 19,1 \\
\hline S. J. do Rio Preto & 1.111 .909 & 17,7 \\
\hline Bauru & 1.100 .658 & 17,6 \\
\hline Ribeirão Preto & 577.747 & 9,2 \\
\hline Sorocaba & 543.177 & 8,7 \\
\hline Campinas & 244.770 & 3,9 \\
\hline Vale do Paraíba & 146.600 & 2,3 \\
\hline São Paulo & 103.329 & 1,6 \\
\hline Total do Estado & 6.274 .814 & 100,0 \\
\hline
\end{tabular}

Fonte: Instituto de Economia Agrícola (IEA), in Toyama \& Martin \& Tachizawa (1976).

Fruto do processo de cientificização do espaço geográfico dinamizado pelas políticas públicas modernizadoras iniciadas em meados da década de 1960, algumas melhorias foram implementadas na atividade pecuária regional. Aproveitando de forma pioneira as opções de crédito oferecidas pelo governo via SNCR, através do Programa de Desenvolvimento da Pecuária de Corte (PRODEPE) e do Programa Nacional de Pastagens (PRONAP), em 1972, enquanto 72,7\% das pastagens brasileiras e 36\% das paulistas ainda eram naturais, na região de Araçatuba quase sua totalidade já era cultivada (96,2\%). Variedades de gramínias braquiárias (Brachiaria ssp), mesmo sendo as de menores custos, riscos e componentes nutritivos, foram introduzidas como inovações em quase todas as propriedades agropecuárias da região.

Em 1973, inaugura-se em Araçatuba uma agência do Conselho Nacional para o Desenvolvimento da Pecuária (Condepe), o que possibilita a aquisição de um canal direto ao governo federal para a obtenção de créditos ao setor. A compra de matrizes e reprodutores de linhagens 
genéticas valorizadas por pecuaristas regionais, representada majoritariamente pela importação de zebuínos da Índia, colocou a região como um dos pontos de referência na biotecnologia da pecuária: mesmo em escala pequena, o mercado de sêmen e a inseminação artificial introduzem na região as técnicas mais modernas de reprodução de rebanhos bovinos, anexando ao espaço geográfico regional a lógica do período técnicocientífico ("invenção do método de invenção”)"4. Além da engorda, já tradicional desde meados do século, incentivados por experiências do Instituto de Zootecnia da Secretaria da Agricultura do Estado de São Paulo e amparados em lócus pela Coordenadoria de Assistência Técnica Integral (CATI) de Araçatuba, cria e recria passam a ser praticadas por poucos pecuaristas, em um sistema integrado onde um mesmo produtor administra todas as etapas do processo, desde o nascimento do bezerro até a entrega ao abate (Martin \& Toyama \& Pires, 1977). Algumas poucas experiências de confinamento, com o uso de técnicas intensivas de manejo alimentício no inverno (momento de escassez de pastagens com a seca) também são iniciadas em algumas propriedades, acarretando o aumento do rebanho regional em 31\% - ou seja, para aproximadamente 1.800 .000 cabeças $^{47}$ - e a melhoria da relação bovinos/ha no intervalo 1970-1980.

Em 1974, aumentando a capacidade de abate e reforçando a posição já conquistada no setor pela região com o Tmaia (800 abates diários) e o Mouran (700 abates diários), surge em Guararapes o frigorífico Noroestino (300 abates diários) ${ }^{48}$. Pela ferrovia, no sentido leste-oeste, e pelas rodovias, em caminhões, o transporte de gado é feito em todas as direções, tornando quase extinta as tradicionais caravanas existentes em grande quantidade até a década de 1950. É um leque de eventos, que em

\footnotetext{
46 Desde 1959, acontecia a "Exposição Regional de Animais e Produtos Derivados de Araçatuba e Região", atual Exposição Agropecuária (Expo) de Araçatuba. Através da iniciativa pública, representada pelo governo estadual e municipal, em aliança com a Associação Rural da Alta Noroeste (Aran) - atual Siran -, a exposição era direcionada a um público limitado composto por zootecnistas, agrônomos, veterinários, produtores, pesquisadores científicos e proprietários rurais. Seus objetivos eram divulgar e comercializar as inovações técnico-científicas realizadas principalmente pelos institutos de pesquisa paulistas.

${ }^{47}$ Sendo 11\% de gado leiteiro (Pino \& Vicente, 1980).

${ }^{48}$ Além desses 3 grandes frigoríficos, é bom ressaltar que 30\% dos abates eram feitos por matadouros rudimentares, sem refrigeração e com técnicas antigas, principalmente para cobrir parte da demanda local e regional (Páez, 1975).
} 
pequena quantidade anexam novos objetos e ações num circuito articulado para o Brasil e o mundo (ainda em pequena proporção) consumirem a carne bovina manejada no espaço geográfico regional.

Contudo, manifestando as contradições da pecuária bovina de corte na região de Araçatuba, mesmo com essas melhorias pontuais (confinamento e biotecnologia) e generalizadas (como as pastagens e o transporte animal), a partir da continuidade do uso extensivo das terras, a maioria dos pecuaristas, sem condições ou interesse em correr riscos com inovações, especulava pelo aparecimento de outras atividades agrícolas com custos de oportunidade mais vantajosos que possibilitassem o uso mais intensivo de suas propriedades ou suas valorizações. Já os mais capitalizados, ao invés de inverterem seus lucros no espaço geográfico regional, aproveitando os estímulos do governo federal para a ocupação do Centro-Oeste e Norte do país (Prodoeste e Sudam), transferiram parte dos seus negócios para essas porções da fronteira agrícola do território brasileiro. Toda esta improdutividade consolidava a região de Araçatuba como aquela de "menor contribuição relativa tanto para a formação do valor da produção agrícola como para o total da área cultivada no oeste paulista e no total do Estado" (VASCONCELOS, 1992, p. 21).

Reflexo dessa situação imposta pelo sistema pecuário foi a limitação do dinamismo industrial na região. Exceto alguns ramos, como o calçadista em Birigui (Zampieri, 1976), o balanço regional das atividades industriais é apresentado como o menor do estado de São Paulo na década de 1970. Cadeia produtiva propulsora de pouca diversidade em seu complexo agroindustrial, em Araçatuba, a pecuária, através de seus atores econômicos - os pecuaristas - não inverteu seus capitais de forma expressiva em inovações ou em outras atividades produtivas, geradoras de diversificação e desenvolvimento. Assim, durante todo o período de intenso crescimento econômico mundial e nacional (1967-1973), onde o interior paulista foi o espaço geográfico mais retribuído (Negri, 1996) com a 
expansão do meio técnico-científico no Brasil ${ }^{49}$, a região de Araçatuba, através do conservadorismo e atraso de suas lideranças políticas e econômicas, não se articulou para a recepção dos altos investimentos existentes naquele momento de liquidez dos mercados.

Chega-se aos anos 1980 e o comparativo demográfico com o momento anterior mostra mais uma vez decréscimo populacional. A expansão do uso de tratores, máquinas e implementos (Hespanhol, 1996; Espírito Santo, 2005), aliada à hegemonia da pecuária, reprimiram com maior intensidade a demanda de mão-de-obra na zona rural regional.

Tabela 12

Região de Araçatuba

População Urbana, Rural e Taxa de Urbanização (1970-1980).

\begin{tabular}{|c|c|c|c|}
\hline Ano & $\begin{array}{c}\text { População } \\
\text { Urbana }\end{array}$ & $\begin{array}{c}\text { População } \\
\text { Rural }\end{array}$ & $\begin{array}{c}\text { Taxa de } \\
\text { Urbanização } \\
(\%)\end{array}$ \\
\hline 1970 & 308.701 & 223.848 & 57,9 \\
\hline 1980 & 407.664 & 122.462 & 76,8 \\
\hline
\end{tabular}

Fonte: Fundação IBGE, Censos Demográficos 1970 e 1980.

Com esse êxodo rural, há retração no número absoluto de habitantes e a região se urbaniza. Araçatuba, Birigui, Penápolis e Pereira Barreto constituíram as áreas urbanas que mais cresceram, recebendo parte dos desempregados rurais que passam a migrar para as cidades.

\footnotetext{
${ }^{49}$ Segundo Assumpção (1984), o I PND (Plano Nacional de Desenvolvimento), implementado entre os anos de 1972 e 1974, tinha como um dos pontos principais "desenvolver a agricultura moderna em bases industriais na região Centro-Sul” (ASSUMPÇÃO, 1984, p. 21).
} 
Tabela 13

Região de Araçatuba

População e Taxas Anuais de Crescimento Populacional por Sub-Região

1970-1980

\begin{tabular}{|c|c|c|c|}
\hline $\begin{array}{c}\text { SUB- } \\
\text { REGIÕES }\end{array}$ & 1970 & 1980 & $\begin{array}{c}\text { Taxa Anual de } \\
\text { Crescimento 1970-1980 } \\
\text { (\%) }\end{array}$ \\
\hline Araçatuba & 350.193 & 379.025 & 0,55 \\
\hline Andradina & 173.707 & 151.101 & $-1,39$ \\
\hline Total & 532.549 & 530.126 & $-0,05$ \\
\hline \% do Estado & 3,00 & 2,12 & 3,43 \\
\hline
\end{tabular}

Fonte: FUNDAÇÃO IBGE, Censos demográficos do Estado de São Paulo de 1970 a 1980

(COSTA \& WONG, 1982, p. 05-06).

Como mostra a tabela acima, a sub-região de Andradina foi a que mais sofreu com a falta de desenvolvimento econômico. De 1969 a 1980, esta porção do espaço geográfico regional, devido principalmente ao alagamento gerado pelas usinas hidrelétricas nela construídas, teve sua área agrícola produtiva diminuída de 473.332 ha para 338.335 ha (Camargo, 1983). Com exceção do milho, todas as outras atividades agropecuárias reduziram seu espaçamento nas terras regionais. Pereira Barreto e Andradina, dois dos municípios dessa sub-região que mais haviam crescido na década de 1960, superando a marca dos 50 mil habitantes, mesmo se urbanizando, recuam sua população na década de 1970, pois não conseguiram absorver em suas áreas urbanas todos os trabalhadores que viviam o êxodo rural e os que ficaram desempregados após a construção das hidrelétricas (Hespanhol, 1996).

Na região como um todo, também se apresentou a diminuição das áreas produtivas, mantendo a pecuária extensiva em 1980 praticamente a mesma proporção (85\% das áreas produtivas) do ano de 1970. Vejamos este quadro de estagnação na tabela abaixo: 
Tabela 14 - Área Cultivada (em hectares) das Principais Atividades Agrícolas Observadas na Divisão Agrícola de Araçatuba (1969-1980)

\begin{tabular}{|l|l|l|l|l|l|}
\hline Ano & $\begin{array}{l}\text { Tomate } \\
\text { Rasteiro }\end{array}$ & Milho & Cana & Amendoim & Algodão \\
\hline 1969 & 920 & 54.860 & 4.550 & 31.934 & 62.484 \\
\hline 1980 & 3.810 & 105.500 & 13.900 & 19.300 & 9.100 \\
\hline
\end{tabular}

\begin{tabular}{|l|l|l|l|l|l|}
\hline Ano & Arroz & Café & Pastagens & $\begin{array}{l}\text { Outras } \\
\text { culturas }\end{array}$ & Total \\
\hline 1969 & 44.697 & 53.713 & 1.540 .617 & 7.778 & 1.797 .003 \\
\hline 1980 & 21.500 & 64.437 & 1.174 .012 & 1.360 & 1.399 .019 \\
\hline
\end{tabular}

Fonte: Instituto de Economia Agrícola (IEA), in Camargo (1983).

Conseqüência dessa involução registrada no setor agrícola e da pouca diversidade industrial e de serviços existentes nas áreas urbanas, no decorrer da década de 1970, a Região Administrativa de Araçatuba continua a sofrer com a migração de parte de sua população para outras regiões, atingindo 1980 uma das densidades populacionais mais baixas do estado (Costa \& Wong, 1982).

Porém, algumas cidades tiveram taxas anuais de crescimento populacional positivas: Araçatuba (1,76\%), Penápolis (1,62\%), Buritama $(1,45 \%)$ Barbosa (1,30\%) e Avanhadava (0,68\%), a partir da introdução das primeiras destilarias da $1^{\text {a }}$ fase do Proálcool e a expansão dos cultivos do tomate rasteiro e do milho em suas proximidades, tiveram um pequeno acréscimo populacional devido à demanda de mão-de-obra para a colheita. Birigui, pólo industrial do calçado infantil, ultrapassando os 50.000 habitantes, é o município que mais expande, com uma taxa média de crescimento entre 1970 e 1980 de 3,82\%. Os outros 31 municípios da região diminuem sua população no mesmo intervalo, continuando aquilo que já vinha acontecendo desde os anos da década de 1950: a polarização de um 
município (Araçatuba), que possuindo os instrumentos de comando regional (sindicatos patronais, instituições públicas estaduais e nacionais de fomento, agências bancárias, etc) serve de intermédio nas decisões daquilo que acontece nas localidades do entorno.

Tabela 15: Distribuição das Aglomerações Humanas na Região de Araçatuba Segundo Classes de População (1980)

\begin{tabular}{|c|c|}
\hline Classes de População & 1980 \\
\hline Até 5 mil & 17 \\
\hline De 5 a 10 mil & 8 \\
\hline De 10 a 20 mil & 5 \\
\hline De 20 a 50 mil & 1 \\
\hline De 50 a 100 mil & 1 \\
\hline De 100 a 200 mil & - \\
\hline De 200 a 500 mil & - \\
\hline Mais de 500 mil & \\
\hline
\end{tabular}

Fonte: FIBGE, Censo Demográfico de 1980. 


\section{3) O Proálcool na Região de Araçatuba na Década de 1980}

Somente no final da década de 1970, onde as economias nacional e mundial vivenciavam o início de uma extensa decadência, que Araçatuba e hinterlândia passam a receber com intensidade investimentos propiciadores de crescimento econômico regional. Data-se, já sob vigência do II PND (1975-1979), com os surgimentos do Programa Nacional do Álcool (Proálcool - 1975), e seus congêneres estadual (Pró-Oeste - 1980) e regional (Plano Regional de Produção do Álcool - 1979), o momento em que as políticas públicas caracterizadoras do processo de modernização do campo brasileiro vão ao encontro dos anseios de parte dos pecuaristas regionais.

A primeira fase do Proálcool (1975-1979), motivada principalmente pelo primeiro choque do petróleo em 1973, incentivou o aumento da produção do etanol - álcool anidro derivado do melaço do açúcar - para utilizá-lo como combustível misturado à gasolina. Destilarias anexas às usinas de açúcar ${ }^{50}$ e destilarias autônomas foram implementadas principalmente em áreas tradicionais da cultura no estado de São Paulo: Ribeirão Preto, Campinas e Bauru, que já fazia algumas décadas direcionavam seus canaviais para a produção de açúcar, a partir de 1975 mantiveram a hegemonia no setor durante esse processo de expansão territorial da cultura ligado à produção de etanol. Partindo da premissa de que no estado de São Paulo a fronteira agrícola já estava quase em seu limite, a expansão da atividade canavieira se deu a expensas de outras culturas. Camargo (1983) nos mostra que no intervalo 1969-1980 a cultura da cana-de-açúcar incorporou 684.479 ha de outras atividades. Pastagens, arroz, amendoim, algodão e mandioca foram respectivamente os produtos que mais cederam áreas para a expansão da cana. Assim, em 1983, com o aprofundamento desse processo de expansão, a área da cultura canavieira representava 28\% do total da área plantada paulista (Yoshii \& Matsunaga, 1984).

\footnotetext{
${ }^{50}$ Um outro motivo colocado para a instalação das destilarias anexas foi a necessidade de se aproveitar a ociosidade do parque industrial sucroalcooleiro, pois o mercado externo do açúcar passava por queda em sua rentabilidade devido a redução nos preços do produto.
} 
Com o aumento da demanda de etanol e a escassez de áreas nas regiões tradicionais, vislumbra-se o oeste paulista como alvo da investida necessária à expansão dos canaviais: nas regiões de Araçatuba, Presidente Prudente e São José do Rio Preto se inicia o planejamento para anexação de novos objetos-técnicos constituintes do circuito espacial de produção canavieiro. Enquanto parte desse espaço geográfico requisitado pelo aumento da demanda do produto no mercado de combustíveis, na $1^{\mathrm{a}}$ fase do Próalcool, quatro projetos enviados pelos fazendeiros da região de Araçatuba foram aprovados, o que resultou na construção das destilarias Aralco, Alcomira, Univalem e Campestre (anexa), nos respectivos municípios de Araçatuba, Mirandópolis, Valparaíso e Penápolis (ESPÍRITO SANTO, 2005, p. 127) ${ }^{51}$.

\section{Foto 39: Panorâmica Aérea da Usina Campestre, em Penápolis}

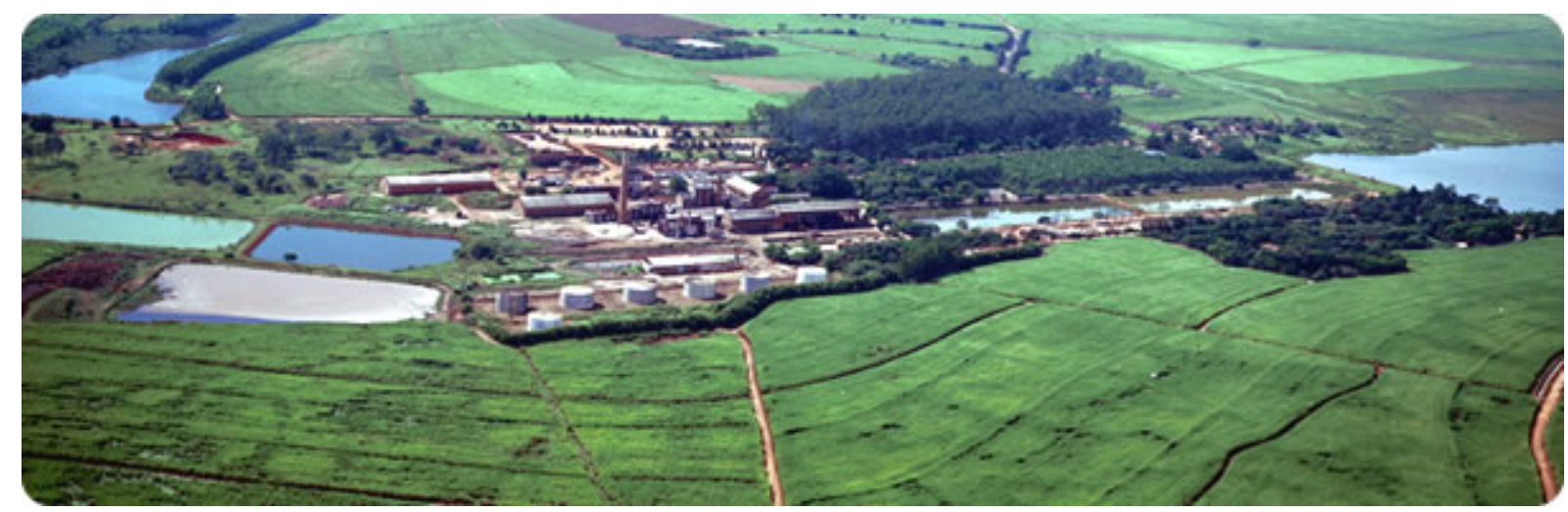

Fonte: http://www.usinacampestre.com.br/, Acesso Disponível em 01/09/2008.

As obras tiveram financiamento de $100 \%$ via SNCR, com juros reais negativos advindos dos subsídios governamentais. Começa a se constituir na Noroeste Paulista - exercendo Araçatuba a centralidade regional desse processo - a territorialidade daquilo que Rego (1990) denominou de binômio cana-boi: como tanto o complexo agroindustrial canavieiro, quanto a cadeia produtiva da pecuária bovina ficou sob o comando econômico dos mesmos atores hegemônicos, a denominação cana-

\footnotetext{
${ }^{51}$ A usina Campestre foi a primeira a processar cana-de-açúcar na região para a produção do açúcar cristal. Fundada em 1946, no ano de 1977, através dos benefícios do Proálcool anexou à unidade já existente a primeira destilaria produtora de etanol combustível na região de Araçatuba.
} 
boi, como manifestação dessa ligação veio a calhar para a interpretação desse fenômeno.

À montante da agroindústria, além do crédito de custeio para a compra dos modernos insumos e máquinas, a elite regional conquistou, via governo federal, a instalação de uma Estação Experimental do Planalsucar ${ }^{52}$ em Valparaíso (Bertero, 1991): assim, as pesquisas pedológicas e de variedades de cana propícias às terras da região foram todas pagas pelos cofres públicos. Era a anexação pela cultura canavieira de mais uma infraestrutura do período técnico-científico, cimentador de um novo momento na produção do espaço geográfico da Noroeste Paulista.

\footnotetext{
52 Já em 1971, no governo militar, foi criado o PLANALSUCAR (Programa Nacional de Melhoramento da Cana-de-Açúcar). O objetivo principal do PLANALSUCAR era o de melhorar a qualidade da cana, dados os baixos índices de rendimento agrícola e industrial obtidos com a matéria prima nacional, quando confrontados com os outros países produtores. As atividades desenvolvidas pelo órgão se direcionavam no sentido de criar tecnologias modernas para o setor. Com laboratórios localizados em várias regiões canavieiras do país, durante sua existência até 1990, o Planalsucar desenvolveu muitíssimas variedades de cana melhoradas, sendo muitas delas, até hoje, matrizes das pesquisas desenvolvidas.
} 


\section{Fotos 40, 41, 42 e 43: Processo de Seleção e Melhoramento Genético}

\section{de Cana-de-Açúcar na Estação Experimental de Valparaíso (SP)}
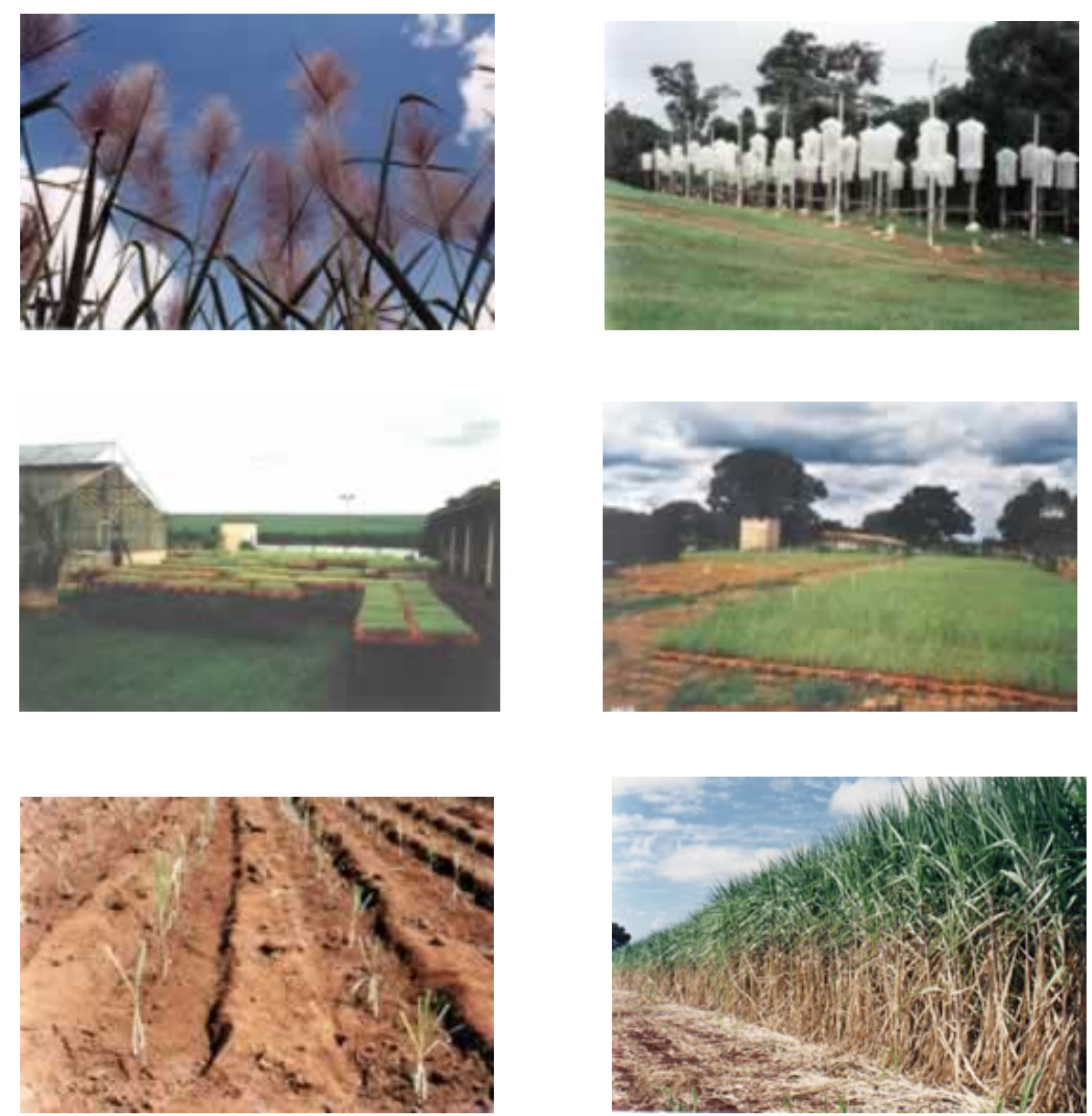

Fonte: http://pmgca.dbv.cca.ufscar.br/htm/pmg/selec.php; Acesso Disponível em 02/08/2008.

A segunda fase do Proálcool se iniciou em 1979. Devido a outro choque no mercado do petróleo, a partir desse momento o governo federal decide investir, junto com as indústrias automobilísticas, na construção de uma frota de veículos movida a álcool hidratado. Para efetivar esse planejamento, novas áreas foram requisitadas e o Noroeste Paulista se torna uma das principais regiões a receber os investimentos para a expansão do setor $^{53}$.

\footnotetext{
${ }^{53} \mathrm{O}$ programa era dirigido fundamentalmente para as áreas de pastagens nas regiões de Araçatuba,
} Presidente Prudente, São José do Rio Preto, Bauru e Marília. 
À nível estadual, criou-se

“... o Pró-Oeste, elaborado pela Secretaria Estadual de Agricultura e Abastecimento em 1979, inicialmente com a denominação de Bases para um Plano de Desenvolvimento do Oeste do Estado de São Paulo. Além do Plano do Governo do Estado, ao nível municipal os 'Usineiros' tiveram o apoio do Conselho Municipal de Desenvolvimento Integrado de Araçatuba” (ESPÍRITO SANTO, 2005, p. 128).

Entre os dias 14 e 21 de maio de 1979, no $23^{\circ}$ Congresso Estadual de Municípios, realizado em Praia Grande (SP), foi apresentado pelo Conselho Municipal de Desenvolvimento Integrado (CMDI) de Araçatuba um 'Estudo Preliminar para a Instalação de Unidades Produtoras de Álcool Carburante na IX Região Administrativa do Estado de São Paulo. Segundo Rego (1990), este documento era acompanhado de cópias do decreto que instituía o Proálcool, do ato do Instituto de Açúcar e do Álcool (IAA) que dispunha sobre o roteiro à implantação de destilarias de álcool e de dados com estimativas de 1975/76 do custo operacional por hectare. Nesse estudo se mostrava que a região de Araçatuba, devido às características ecológicas, à disponibilidade de áreas e o nível avançado de mecanização, apresentava condições favoráveis para a implantação de destilarias. Nele se argumentava que toda a produção demandada seria conquistada se utilizando apenas $20 \%$ das áreas de pastagens de propriedades acima de 500 ha e $10 \%$ das áreas de pastagens de propriedades cujas áreas variassem de 100 a 500 ha. Relatavase que essas áreas estariam disponíveis tendo em vista que nem toda área registrada como pastagem era convenientemente ou racionalmente conduzida, apresentando visivelmente aspectos de áreas abandonadas. Apresentava-se no documento informações que continham o cálculo do lucro líquido da produção de cana por hectare comparado com o lucro que se obtinha com o gado no mesmo espaço. Tudo isso, para convencer mais pecuaristas a aderirem ao Proálcool.

Especificando as políticas públicas favorecedoras da instalação do complexo agroindustrial canavieiro no espaço geográfico regional estudado, em 1980, como já citamos, foi lançado o Plano de Desenvolvimento Agrícola do Oeste de São Paulo, o Pró-Oeste. Amparado por um 'Programa 
de Expansão da Canavicultura para Produção de Combustível do Estado de São Paulo’ (Pró-Cana), o Pró-Oeste nada mais foi que um braço estadual do plano federal (Proálcool).

Dentre os principais objetivos do plano, elaborado pela Secretaria de Agricultura e Abastecimento do estado de São Paulo, apresentados por Rego (1990), temos:

“... inversão do fluxo migratório, face à criação de empregos diretos e indiretos necessários à consolidação do programa; - interiorização do desenvolvimento pelo fortalecimento das economias regionais; preservar e ampliar a oferta de alimentos, bem como manter a expressiva participação do setor agropecuário paulista na pauta de exportação” (REGO, 1990, p. 71).

Na busca de convencer os pecuaristas, donos da maioria das terras, a aderirem à cultura canavieira, os técnicos paulistas apresentaram as possibilidades de intensificação do manejo do gado de corte, concentrandoos em pequenos espaços e utilizando o bagaço da cana temperado como ração. Assim, o discurso do Pró-Oeste é dirigido aos pecuaristas, “que além das vantagens com a produção de cana, teriam apoio para o desenvolvimento da própria pecuária” (Rego, 1990, p. 73).

O Pró-Cana, orientando o fluxo dos recursos financeiros oriundos do Proálcool, potencializa o Pró-Oeste, mostrando aos pecuaristas a possibilidade de utilização de parte da área de pastagens para a produção de cana, produzindo empregos e alimentos com a rotação de culturas durante a renovação dos canaviais ${ }^{54}$.

Sobre a posição dos pecuaristas, Espírito Santo (2005), diz que,

“... ao optarem pelas benesses do Proálcool (crédito, programas de apoio, compra garantida pelo governo), eles, como era de se esperar, não queriam correr risco algum ao trocar de atividade produtiva para o que contaram com o imprescindivel apoio do Estado" (ESPÍRITO SANTO, 2005, p. 128).

54 O plano expressa também a preocupação com a redução da produção de alimentos em áreas tradicionais de cana-de-açúcar como Ribeirão Preto e Campinas. Todo um cuidado foi apresentado para que nas novas áreas do oeste paulista a ocupação da cana acontecesse de forma mais ordenada, preservando a produção e o abastecimento de alimentos na região. 
A elite regional se convence do bom negócio ${ }^{55}$ e em 1981, com a aprovação de novos projetos, instalam-se na região novas usinas: Benalcool (Bento de Abreu), Unialcool (Guararapes), Generalcool (General Salgado), Destivale, Alcoolazul e Cruzalcool (Araçatuba) ${ }^{56}$. Reflexo disso, em dois anos, de 1980 a 1982, a área regional plantada com cana passa dos $15 \mathrm{mil} \mathrm{ha}$ para 48 mil ha (Rego, 1990). Em 1983, expande-se para 83.290 ha, chegando na safra 1985/1986 a 111.370 ha (Veiga Filho \& Matsunaga \& Yoshii, 1987). Representando a $6^{a}$ maior região em extensão no plantio de cana-de-açúcar - entre as 10 do estado no momento -, a região de Araçatuba passa a exercer sua função dentro da divisão setorial do trabalho no circuito espacial canavieiro. Na associação com a materialidade hegemônica pretérita constituída pelos sistemas de objetos e ações do circuito pecuário, concretiza-se o que ficou conhecido como sistema ou consórcio cana-boi.

No estado, no biênio 1981/82, a área total com cana-de-açúcar chegou a 1.343 .400 hectares, aumento de 4,1\% relacionado ao biênio precedente e $77 \%$ ao de dez anos antes (1971/72). Igualmente expressiva foi a evolução do rendimento agrícola (produtividade), que turbinado pelos projetos de melhoramento genético do Planalsucar, registrou o crescimento de 29\% na década de 1970 (Bertero, 1991).

\footnotetext{
${ }^{55}$ Segundo Rego (1990), trocando o certo pelo absolutamente certo.

${ }^{56}$ No Brasil, no ano de 1981, foram aprovados 175 projetos para a construção de novas destilarias anexas e autônomas enquadrados no Proálcool. O estado de São Paulo foi o mais contemplado, com a aprovação de 151 desses projetos (IAA, 1981).
} 
Tabela 16 - Evolução da Área Total Plantada com Cana-de-Açúcar, por

Divisão Regional Agrícola, Estado de São Paulo, 1970/1971 - 1985/1986 (em hectares).

\begin{tabular}{|c|c|c|l|l|}
\hline $\begin{array}{c}\text { Divisão } \\
\text { Regional }\end{array}$ & $1970 / 1971$ & $1975 / 1976$ & $1980 / 1981$ & $1985 / 1986$ \\
\hline Rib. Preto & 256.520 & 322.600 & 532.200 & 707.430 \\
\hline Campinas & 278.300 & 292.900 & 335.600 & 430.790 \\
\hline Bauru & 93.595 & 133.233 & 187.800 & 288.060 \\
\hline Marília & 33.939 & 44.767 & 88.300 & 193.050 \\
\hline S J Rio Preto & 21.780 & 61.300 & 78.300 & 133.100 \\
\hline Araçatuba & $\mathbf{5 . 3 2 4}$ & $\mathbf{7 . 9 0 0}$ & $\mathbf{3 2 . 0 0 0}$ & $\mathbf{1 1 1 . 3 7 0}$ \\
\hline Sorocaba & 53.240 & 62.900 & 83.000 & 90.390 \\
\hline P. Prudente & 363 & 8.200 & 38.000 & 73.970 \\
\hline V. Paraíba & 3.267 & 2.500 & 2.410 & 2.800 \\
\hline São Paulo & 3.872 & 2.100 & 2.150 & 140 \\
\hline Estado & 750.200 & 938.400 & 1.379 .760 & 2.031 .100 \\
\hline
\end{tabular}

Fonte: Instituto de Economia Agrícola (IEA).

São novos objetos e ações que passam a ditar a lógica territorial da região. Mesmo cobrindo um percentual irrisório do circuito pecuário, continuam as experiências de confinamento e manejo de pastagens (Vasconcelos, 1982) ${ }^{57}$. Outros direcionam suas boiadas para as novas áreas de fronteira agrícola no Centro-Oeste e no Norte do país. Valorizam-se as terras no campo e nas cidades da hinterlândia do município de Araçatuba, onde ao findar da década de 1980 se centraliza politicamente o setor na região noroeste do estado de São Paulo: cidade-sede da União das Destilarias do Oeste Paulista (UDOP), o município, através dessa entidade patronal, representava o setor em 1989 com 21 usinas de açúcar e álcool

\footnotetext{
${ }^{57}$ O Professor de Economia em Araçatuba, Ricardo de Assis Perina, em entrevista realizada no dia 01 de outubro de 2007, relatou-nos duas experiências de confinamento de bovinos realizadas no início dos anos 1980. A primeira, tentada pela tradicional família pecuarista Tozi, devido aos riscos de custos e de escalas, não vingou. Já a empreendida pela Usina Univalem, no uso do bagaço da cana como alimento, segundo Perina, acontece até os dias atuais.
} 
associadas. Sendo 11 dessas usinas localizadas além dos limites rígidos da Região Administrativa de Araçatuba ${ }^{58}$, nela algumas captavam parte da matéria-prima que necessitavam e todas eram assessoradas técnica e politicamente pelos profissionais da UDOP. Sendo viável para os custos de produção de uma usina de açúcar e álcool negociar a compra de cana em terras com distância da unidade produtiva ao redor dos 20 kilômetros (Veiga Filho, 1998), usinas localizadas dentro da RA de Araçatuba compravam parte da cana-de-açúcar requisitada para sua produção fora da circunscrição engessada da $\mathrm{RA}^{59}$. Dessa forma, dentro da escala rígida regional, o conteúdo da ocupação da cana-de-açúcar se estabilizou nesse final de década em aproximadamente 100.000 hectares (Espírito Santo, 2005).

Analisando a distribuição da produção agrícola na área regional, em 1990, em relação à década anterior, apresenta-se um aumento das áreas produtivas com uma maior diversificação de culturas. Diminui a proporção das terras direcionadas para as pastagens, de aproximadamente 85\% para 78,5\% do total: contudo, como houve aumento da área agrícola, entre 1980 e 1990, essa menor proporção na verdade revelou um aumento da ocupação da pecuária de 1.174.012 ha para 1.316.090 ha (Ferreira et al., 1990). Com a diminuição do rebanho devido à transferência de parte dos negócios do circuito pecuário para terras mais baratas no Centro-Oeste do Brasil, a esperada expansão no setor de novas técnicas de manejo (confinamentos) não aconteceu: a relação bovinos/ha diminuiu entre 1980 e 1990:

\footnotetext{
${ }^{58}$ A Goálcool funciona até os dias atuais no município de Serranópolis, em Goiás.

59 Essa realidade mostra a dificuldade do estudo das regiões. Mesmo tendo escolhido uma delimitação territorial normatizada pelas políticas públicas do estado, compreendemos e defendemos nesse estudo que mesmo possuindo seus conteúdos característicos de suas especifidades, as regiões são parte de uma totalidade maior, ou seja, são uma totalidade parcial do mundo em movimento. Sendo assim, na contigüidade e em rede, as variáveis nelas presentes extrapolam suas delimitações, mantendo relações em escalas hoje cada vez mais globalizadas.
} 
Tabela 17

Região de Araçatuba

Área de Ocupação das Pastagens, Número do Rebanho Bovino

e Relação Bovinos/Ha (1970-1990)

\begin{tabular}{|l|c|c|c|}
\hline Ano & $\begin{array}{c}\text { Área de } \\
\text { Pastagens } \\
(\text { Ha })\end{array}$ & $\begin{array}{c}\text { Número do } \\
\text { Rebanho } \\
\text { Bovino }\end{array}$ & $\begin{array}{c}\text { Relação } \\
\text { Bovino/Ha }\end{array}$ \\
\hline 1970 & 1.540 .617 & 1.373 .000 & 0,89 \\
\hline 1980 & 1.174 .012 & 1.800 .000 & 1,53 \\
\hline 1990 & 1.271 .090 & 1.595 .157 & 1,25 \\
\hline
\end{tabular}

Fonte: FIBGE-SIDRA (1970-1980); Instituto de Economia Agrícola, IEA, 1990.

A cultura do milho se manteve com uma ocupação ao redor de 7,5\% das áreas produtivas regionais; a cana-de-açúcar expandiu de 1\% para 6,47\% das áreas; o tomate rasteiro, devido à diminuição de suas áreas em outras regiões do estado e a localização da agroindústria Paoletti em Araçatuba, mesmo ocupando 0,17\% da área regional, passa a concentrar em 1989, 30\% da produção paulista. Cebola e feijão de inverno também expandem. Banana, mandioca, mamona, tangerinas, amendoim, algodão, arroz e café perdem área.

Reflexo principalmente da expansão das áreas destinadas à lavoura canavieira - que requer alta quantidade de mão-de-obra principalmente no período da colheita - na região de Araçatuba, dos 37 municípios existentes, 25 deles, através do recebimento de migrantes principalmente do Nordeste e de Minas Gerais, tiveram aumento em sua população total e 36 tiveram aumento de sua população urbana, o que registra crescimento no índice de urbanização regional. 
Tabela 18

Região de Araçatuba

População Urbana, Rural e Taxa de Urbanização (1980-1991)

\begin{tabular}{|c|c|c|c|}
\hline Ano & $\begin{array}{c}\text { População } \\
\text { Urbana }\end{array}$ & $\begin{array}{c}\text { População } \\
\text { Rural }\end{array}$ & $\begin{array}{c}\text { Taxa de } \\
\text { Urbanização } \\
(\%)\end{array}$ \\
\hline 1980 & 407.664 & 122.462 & 76,8 \\
\hline 1991 & 577.610 & 72.193 & 87,5 \\
\hline
\end{tabular}

Fonte: Fundação IBGE, Censos Demográficos 1980 e 1991.

Para Rego (1990),

“... as pequenas cidades estudadas conheceram um rápido crescimento populacional a partir da simples notícia da implantação das destilarias de álcool. Loteamentos novos, conjuntos habitacionais, cortiços e favelas abrigam os migrantes que se dirigem para as cidades da Região. É uma paisagem nova que abriga velhos problemas sociais brasileiros, alguns dos quais, até então não presentes nesse espaço ...” (REGO, 1990, p. 113).

Araçatuba e Birigui são os municípios que mais crescem entre os anos de 1980 e 1991. Sob o impacto do dinamismo agroindustrial sucroalcooleiro, com 40.000 novos moradores registrados, o municípiosede da região intensifica sua função de prestador de serviços regionais, ampliando sua cobertura nos setores públicos (saúde, educação, habitação, etc), bancários, do comércio em geral, de logística (armazenagem, transporte, comercialização, hotelaria), entre outros. Novos loteamentos urbanos são criados na periferia para assistir a demanda por moradias populares (Vasconcelos, 1992) e edifícios verticais com vários pavimentos são construídos em grande quantidade para atender principalmente a mãode-obra qualificada do setor sucroalcooleiro (Pinheiro \& Bodstein, 1997). 


\section{Foto 44: Retrato da Verticalização Central de Araçatuba}

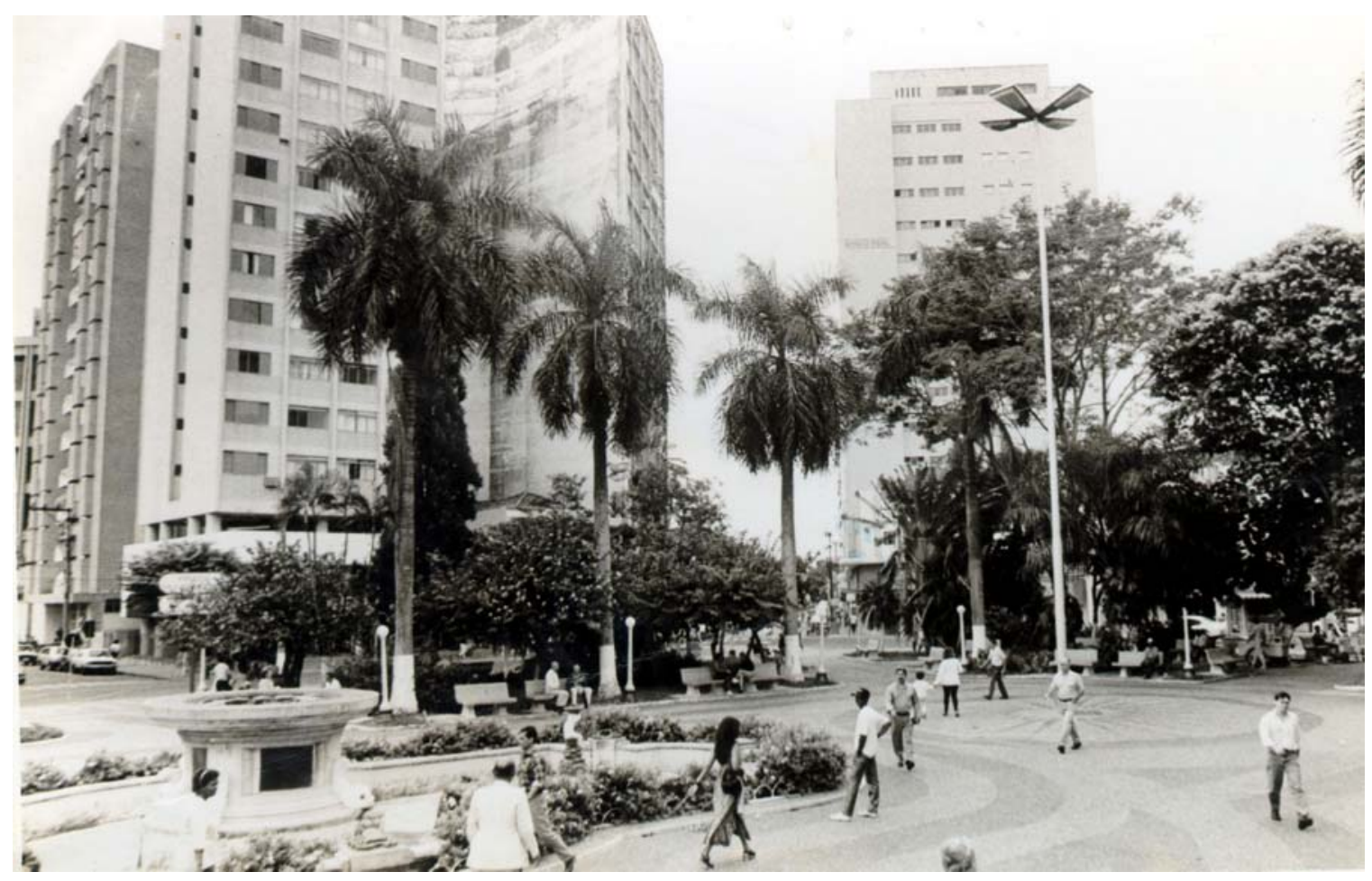

Fonte: Câmara Municipal de Araçatuba (sem data).

Birigui, segundo maior município da região, consolidandose popularmente como "a capital latino-americana do calçado infantil”, recebeu 25.000 novos moradores no decorrer da década de 1980. Com o aumento do número de estabelecimentos fabris e de empresas fornecedoras de insumos, a área urbana birigüiense cresce em quase todas as direções. Distantes 10 Quilômetros uma da outra, as áreas urbanas de Araçatuba e Birigui começam a ser interrogadas pela possibilidade de conurbação (Vasconcelos, 1992), ou melhor, pela formação de uma aglomeração urbana não-metropolitana (Gomes, 2007). 
Tabela 20: Distribuição das Aglomerações Humanas na Região de Araçatuba Segundo Classes de População (1991)

\begin{tabular}{|c|c|}
\hline Classes de População & 1991 \\
\hline Até 5 mil & 16 \\
\hline De 5 a 10 mil & 7 \\
\hline De 10 a 20 mil & 4 \\
\hline De 20 a 50 mil & 2 \\
\hline De 50 a 100 mil & 1 \\
\hline De 100 a 200 mil & - \\
\hline De 200 a 500 mil & - \\
\hline Mais de 500 mil & \\
\hline
\end{tabular}

Fonte: FUNDAÇÃO IBGE, Censo demográfico do Estado de São Paulo de 1991.

Contudo, esse aumento populacional da região de Araçatuba foi quase 3 vezes menor do que o aumento populacional ocorrido em todo o estado de São Paulo:

Tabela 21

Região de Araçatuba População e Taxas Anuais de Crescimento Populacional por Sub-Região 1980-1991

\begin{tabular}{|c|c|c|c|}
\hline $\begin{array}{c}\text { SUB- } \\
\text { REGIÕES }\end{array}$ & 1980 & 1991 & $\begin{array}{c}\text { Taxa Anual de } \\
\text { Crescimento 1980-1991 } \\
\text { (\%) }\end{array}$ \\
\hline Araçatuba & 379.025 & 413.193 & 0,90 \\
\hline Andradina & 151.101 & 164.417 & 0,88 \\
\hline Total & 530.126 & 577.610 & 0,89 \\
\hline \% do Estado & 2,12 & 1,82 & 2,61 \\
\hline
\end{tabular}

Fonte: FUNDAÇÃO IBGE, Censos demográficos do Estado de São Paulo de 1980 a 1991. 
A involução metropolitana financiada pelo poder público via principalmente o II PND - com o objetivo de superar a crise substituindo importações - privilegiou uma interiorização do desenvolvimento mais próxima da Grande São Paulo. Foram as regiões de Campinas, São José dos Campos, Sorocaba, Piracicaba e Ribeirão Preto as que anexaram aos seus espaços geográficos regionais, com maior diversidade, os sistemas de objetos e ações propiciadores de crescimentos econômicos e demográficos maiores do que os do Oeste Paulista e da própria Região Metropolitana. A indústria química, mecânica, aeronáutica, a "indústria para a agricultura”, uma rede de estradas duplicadas, entre outros, são elementos que deram para o “interior próximo" à Grande São Paulo uma constituição de extensão da metrópole.

Limitado numa estrutura produtiva pouco diversificada, o oeste paulista concentrou nesse processo basicamente os “... segmentos predominantemente produtores de bens de consumo não-duráveis, em especial os da indústria alimentícia” (NEGRI, 1992, p.74). Embora possuidora de uma rede viária bem articulada - com a região de Araçatuba sendo cortada por duas grandes rodovias pavimentadas (SP 310 Washington Luiz e SP 300 - Marechal Rondon) e “... algumas outras menores como a SP 425 (que liga o oeste paulista ao estado de Goiás ao Norte e ao Estado do Paraná ao Sul) e a SP 461 (que liga a cidade de Birigui ao Rio Grande, no município de Cardoso) (VASCONCELOS, 1992, p. 38) - o oeste apresentava, no final dos anos 1980, um sistema viário bem menos denso do que o “interior próximo” à Grande São Paulo.

A região de Araçatuba, mesmo com a expansão da cultura canavieira - que condicionou um incremento de riqueza na economia regional -, manteve sua estrutura hegemônica de planejamento do espaço geográfico nas mãos dos pecuaristas, como bem relatado por Rego (1990) no denominado sistema cana-boi. Diferente da região de Ribeirão Preto, que se constituiu como a principal região do Proálcool no estado e no Brasil, Araçatuba - e o oeste - absorveu de maneira marginal e conservadora os benefícios do programa (somente 5,4\% da produção estadual na safra 1885/86). Enquanto as “indústrias para a agricultura” (de produtos físico- 
químicos, mecânicos, e biológicos) continuaram concentradas principalmente nas regiões de Ribeirão Preto e Campinas, instalaram-se nas novas áreas (Araçatuba, São José do Rio Preto e Presidente Prudente), além das usinas, destilarias e dos canaviais, somente os serviços comerciais, de manutenção e de extensão rural direcionados à cultura.

Assim, entendemos que a situação que mais pesou na limitação do desenvolvimento regional foi a continuidade da hegemonia do uso das terras regionais pela pecuária super-extensiva durante a década de 1980. As anexações inovadoras dadas pelas experiências de confinamento e do sistema integrado do manejo bovino foram pontuais no espaço geográfico regional. O conservadorismo gerado pelos riscos dos retornos das inovações e pelos custos de oportunidades em se investir em outras culturas predominou na classe pecuarista. Legitimados pela posse concentrada da terra, esses atores hegemônicos adentram a década de 1990 continuando a exercer o domínio sobre as possibilidades de encaminhamento daquilo que se anexará no espaço geográfico para a geração da riqueza e do desenvolvimento na região. 


\section{Capítulo 5}

\section{As Reformas dos Anos 1990:}

\section{A Reestruturação Produtiva do Espaço Geográfico}

Desde o choque dos mercados e a elevação das taxas de juros internacionais em 1979, os países da América Latina passaram a enfrentar sérios problemas de divisas em relação ao exterior. Inflação alta com instabilidade no plano econômico interno foi regra em toda a região. No Brasil, a partir de uma política baseada na substituição de importações e aceleração das exportações, as tentativas de estabilização e retomada do crescimento foram realizadas. Contudo, atravessaram-se os anos 1980 e não se obteve sucesso.

Como diagnóstico desse processo, hegemonizou-se a tese que apresentava a grande participação do Estado na economia e no fechamento do mercado interno ao comércio internacional como as prerrogativas da crise vigente. Para os defensores dessa interpretação, a utilização de subsídios à produção local e de barreiras às importações foi o que ocasionou os desequilíbrios nos mercados nacionais desencadeados na década de 1980. O regime de substituição de importações teria provocado um encaminhamento do comércio da produção nacional para o mercado doméstico, rebaixando as relações com o mercado externo e impossibilitando a competitividade geradora de qualidade da oferta e crescimento. Essa proteção do mercado interno teria feito com que as indústrias locais enfrentassem uma menor pressão concorrencial do que aquela prevalecente no mercado mundial, desestimulando a busca de aumento da produtividade.

No raiar dos anos 1990, direcionadas pelos indicativos de instituições internacionais como o Fundo Monetário Internacional, o Banco Interamericano de Desenvolvimento e o Banco Mundial, as plataformas políticas do Brasil e do continente se encaminharam para um caminho convergente, denominado “Consenso de Washington” (Pereira, 1992). Entre as principais orientações colocadas estavam a necessidade de: a) 
abertura comercial ao exterior; b) liberalização financeira; c) reforma previdenciária; d) reforma trabalhista; e) reforma tributária redutora do déficit público; f) privatizações; g) políticas anti-inflacionárias e de ajustes. A retomada do crescimento passaria pela aplicação desses indicativos.

Convencidos por essa interpretação, essas reformas começaram a ser introduzidas no território brasileiro no biênio 1988-89. Alterações na estrutura tarifária, com a redução das tarifas médias, abolição de regimes especiais de importação e unificação de tributos aos produtos do exterior começam a ser instaladas (Kume,1996). Em 1990, lança-se a Política Industrial e de Comércio Exterior (PICE), que aplicada a partir de 1992, enfatiza o papel dos setores exportadores e sua associação com os setores geradores de progresso técnico.

Como resultado dessa liberalização comercial, de 1990 a 1994, a tarifa média aos produtos importados se reduziu de 32\% a 14\%. A partir do Plano Real, a política comercial é utilizada como forma de garantir a estabilidade monetária. Na falta de capacidade produtiva instalada no parque industrial nacional para abastecer a demanda doméstica, as mercadorias importadas passam a ser introduzidas de forma facilitada com o objetivo de impedir a volta da inflação. Acordos são impostos pelas resoluções da Organização Mundial do Comércio (OMC) e a reestruturação produtiva dos setores passa a ser norma na busca de manter a competitividade à nível internacional. Subsídios estatais se tornam escassos e o financiamento da produção se direciona como função de sistemas privados industriais e financeiros. Privatizações de empresas estatais são realizadas em todos os níveis (municipal, estadual e federal) e o ideário do Estado Mínimo Neoliberal entra em voga como solução à crise (Menezes \& Fonseca, 2003). Levados pelas facilidades colocadas, vários setores passam a receber grandes investimentos do capital internacional e incorporações e fusões são realizadas na intenção de se alcançar as escalas necessárias à competição do mercado mundial.

Mudanças organizacionais e tecnológicas se tornam necessárias nos embates do mercado comercial globalizado: as novas técnicas de informação surgem como o paradigma moderno desse processo (Tigre, 1993). Para diminuir custos, identificar perdas e acelerar a atividade e o 
controle da produção, os atores hegemônicos de todos os setores são obrigados a renovar seus parques produtivos para continuarem competitivos no mercado. Novas máquinas e instalações acopladas por sistemas (softwares) informatizados se tornam as inovações do novo período das relações produtivas: são novos sistemas de objetos e ações, que constituídos e sistematizados pela precisão das técnicas da informação, qualificam o espaço geográfico como meio técnico-científico-informacional (Santos, 1994; 2002).

Implementada nos países mais desenvolvidos depois da Segunda Guerra Mundial, e no Brasil nos anos 1970 (Ramos, 2001), a união entre a ciência, a técnica e a informação, como eixo normatizador das relações hegemônicas universais atinge sua fase madura com a globalização iniciada nos anos 1990 (Santos \& Silveira, 2001). Assim, com a abertura comercial projetada pelas reformas neoliberais, só passam a resistir à competitividade globalizada os atores econômicos que instauram inovações possibilitadoras da obtenção de menores custos de produção. Sendo a técnica da informação - através da precisão e controle que ela estabelece - o principal elemento inovador que capacita a diminuição dos gastos no processo produtivo, sua instalação acoplada aos objetos e ações desse novo momento histórico é norma para a subsistência no mercado global. 


\section{1) Reestruturação Produtiva na Agricultura}

A desestruturação do setor público foi progressivamente transferindo para o setor privado atividades que eram tradicionalmente atribuídas ao Estado. Financiamento da produção agrícola, políticas de estabilização da produção, a orientação da pesquisa tecnológica, a provisão de informações: no decorrer da década de 1990, essas atividades passaram a ser articuladas pelos atores do mercado, ficando o Estado com a incumbência de principalmente fiscalizar todo esse processo (Farina, 1996).

Grandes agroindústrias, grupos financeiros e empresas de insumos e máquinas, de maneira integrada, começam a assumir a maior parte do financiamento agrícola, onde novos instrumentos financeiros começam a surgir como forma de viabilizar a produção e a comercialização de produtos agropecuários. Adiantamento de Contratos de Câmbio (ACC), Cédula do Produtor Rural (CPR), Finame Agrícola, Contrato de Investimento Coletivo (CIC) e Pregões Eletrônicos aparecem no decorrer da década de 1990 - e adentram os anos 2000 - como as principais fontes alternativas de investimento e custeio da atividade agrícola moderna no Brasil. Somente como avalista de parte desse capital, nesse cenário de escassez do crédito rural oficial, o Estado, através do Banco do Brasil e do BNDES (Banco Nacional de Desenvolvimento Econômico e Social), passou a direcionar recursos a taxas de juros favorecidas,

\footnotetext{
“... apenas à agricultura de baixa renda, através de programas especiais, como o Programa Nacional da Agricultura Familiar (PRONAF), o Programa de Geração de Emprego e Renda (PROGER) e o Programa Especial de Crédito para a Reforma Agrária (PROCERA)" (BELIK \& PAULILLO, 2001, p.14).
}

Desarticulada as amarrações do momento anterior, coloca-se como desafio, para enfrentar a concorrência globalizada, a construção de novos arranjos organizacionais. Controlados cada vez mais por atores internacionais, modernizam-se os parques agroindustriais, construindo plantas padronizadas com as novas tecnologias da informação. Aprofundam-se os investimentos em inovações físico-químicas, mecânicas 
e biotecnológicas, expandindo a porção do espaço geográfico brasileiro definida como meio técnico-científico-informacional (Elias, 1996).

Resultado desse esforço, a agricultura no Brasil passa a se destacar como uma das mais produtivas do mundo. Aumentando sua representação no PIB nacional entre 1990 e 2004, o setor agrícola, através de complexos agroindustriais como o do algodão, da cana-de-açúcar, de cereais e oleaginosas, de frutas e de carnes bovina, suína e de aves, alcançou altos índices de produtividade e competitividade e conquistou mercados no exterior (Gonçalves \& Souza \& Vicente, 2004).

O estado de São Paulo, mesmo tendo diminuído sua participação no PIB nacional entre 1990 e 2003, continua sendo o estado com maior participação no valor da produção agropecuária do Brasil, respondendo por 17,8\% do total do país em 2003 (Tsunechiro, 2006). Somando quase metade desse montante, cana-de-açúcar e carne bovina responderam por $45 \%$ do valor da produção paulista em 2004. Adicionadas a laranja, carne de frango e milho, para o mesmo ano, atingem essas culturas 63\% do valor da produção estadual (Martins et al., 2006).

O oeste paulista, com a gradual modernização da pecuária bovina de corte e a expansão da cultura canavieira a partir do novo "boom” do etanol nos anos 2000, apresentou significativo crescimento do valor de sua produção. Entender esse processo e suas implicações sócio-espaciais, especificamente na região de Araçatuba, é o que tentamos fazer nos próximos sub-capítulos desse trabalho. 


\section{2) A Região de Araçatuba no Limiar do Século XXI}

No ano de 1989, o preço do barril do petróleo atinge preços baixíssimos e a cotação do açúcar sobe no mercado internacional: é a crise de abastecimento do álcool. Os consumidores passam a preferir os carros a gasolina, pois estes começam a apresentar preços relativos melhores: os usineiros direcionam seus investimentos para a produção do açúcar (Veiga Filho, 1998).

Com essa queda da demanda do etanol, em meados da década de 1990, destilarias autônomas interromperam ou diminuíram muito suas produções e com a desregulamentação do setor (com o fim dos subsídios) uma reestruturação produtiva é iniciada. Aumentaram-se as escalas de produção das unidades agroindustriais, tendendo a permanência somente dos grupos mais capitalizados (Thomaz Jr., 1996).

O mesmo acontece com a cadeia produtiva da carne bovina. Novos frigoríficos (equipados com as inovações do momento) são levantados nas regiões mais próximas das novas invernadas (Centro-Oeste e Norte), reduzindo a importância relativa do estado de São Paulo no setor (De Zen, 1997). Nesse processo de reestruturação ocorreram a compra dos dois grandes frigoríficos da região - Mouran (Andradina) e TMaia (Araçatuba) ${ }^{60}$ - pelo grupo Sadia em 1989 (Dalla Costa, 1993) e o fechamento do último o de Araçatuba - no início dos anos 1990 (Pinheiro \& Bodstein, 1997).

Nesse desencadear de transformações, entre 1990 e 2000, a pecuária bovina de corte, mesmo diminuindo sua extensão de 1.271.090 ha para 1.198.254 ha, manteve-se como atividade hegemônica, ocupando em torno de $80 \%$ das terras da região com um aumento do número do rebanho em quase 300.000 cabeças, a partir de um manejo prioritariamente extensivo, onde a busca de melhoramentos genéticos dos plantéis (com obtenção de precocidade do rebanho), manejo de pastagens melhoradas

\footnotetext{
${ }^{60}$ Desde o início dos anos 1980, o frigorífico de Araçatuba (Tmaia) pertencia à família do grupo Mouran.
} 
continuaram sendo apontamentos de intensificação de uma minoria de pecuaristas $^{61}$.

Tabela 22

Região de Araçatuba

Área de Ocupação das Pastagens, Número do Rebanho Bovino e Relação

Bovinos/Ha (1990 - 2000)

\begin{tabular}{|c|c|c|c|}
\hline Ano & $\begin{array}{c}\text { Área de } \\
\text { Pastagens } \\
(\mathrm{Ha})\end{array}$ & $\begin{array}{c}\text { Número do } \\
\text { Rebanho } \\
\text { Bovino }\end{array}$ & $\begin{array}{c}\text { Relação } \\
\text { Bovino/Ha }\end{array}$ \\
& & & \\
\hline 1990 & 1.271 .090 & 1.595 .157 & 1,25 \\
\hline 2000 & 1.198 .254 & 1.851 .916 & 1,54 \\
\hline Fonte: Instituto & de $\quad$ Economia & Agrícola $\quad$ (IEA), Banco de Dados \\
\hline
\end{tabular}

(http://www.iea.sp.gov.br/out/banco/menu.php); Acesso Disponível em 14/08/2008.

Também cederam área nesse período as culturas do algodão, arroz, feijão, amendoim, café, laranja, milho e tomate rasteiro (Olivetti et al., 2003). Abacaxi, soja e cana-de-açúcar foram as culturas que mais expandiram nesse intervalo, atingindo a lavoura canavieira - mesmo com uma taxa de crescimento menos expressiva que os anos 1980 - a segunda colocação entre as atividades agropecuárias com maior extensão na ocupação do espaço agrícola regional (10,4\%).

Sendo a cultura canavieira demandante de grande quantidade de mão-de-obra, principalmente no período da colheita, aumenta-se a população dos municípios que com localizações próximas das usinas foram receptores de canaviais. Estando estes presentes principalmente na subregião de Araçatuba, como presenciamos na tabela abaixo, é essa sub-região que apresenta um maior aumento demográfico nessa última década do século XX. Penápolis, como uma cidade tradicional do setor sucroalcooleiro

\footnotetext{
${ }^{61}$ Cabe destacar que desde 1989, fruto do lobby desencadeado pela elite pecuarista regional frente ao poder público estadual, Araçatuba adquiriru as instalações de uma unidade do curso de medicina veterinária da Unesp. Através da formação de profissionais especializados no manejo da pecuária, a atividade passa a obter uma maior oferta de mão-de-obra qualificada e acesso mais facilitado às inovações tecnológicas e organizacionais do setor.
} 
- com 30\% da sua ocupação territorial executada pela cana-de-açúcar -, ultrapassa os 50.000 habitantes; Araçatuba, capital regional - mesmo com o desmembramento de seu território para a criação do município de Santo Antônio do Aracanguá - aumenta sua população em 20.000 pessoas; e Birigui, a partir da expansão de suas exportações de calçados, revigora suas escalas de produção, demandando mão-de-obra e recebendo no intervalo 1991-2000 quase 20.000 novos moradores.

\section{Tabela 23}

Região de Araçatuba População e Taxas Anuais de Crescimento Populacional por Sub-Região 1991-2000

\begin{tabular}{|c|l|l|c|}
\hline $\begin{array}{c}\text { SUB- } \\
\text { REGIÕES }\end{array}$ & 1991 & 2000 & $\begin{array}{c}\text { Taxa Anual de } \\
\text { Crescimento 1991-2000 } \\
(\%)\end{array}$ \\
\hline Araçatuba & 413.193 & 464.339 & 1,10 \\
\hline Andradina & 164.417 & 171.200 & 0,39 \\
\hline Total & 577.610 & 635.539 & 1,00 \\
\hline \% do Estado & 1,82 & 1,71 & 1,46 \\
\hline
\end{tabular}

Fonte: FUNDAÇÃO IBGE, Censos demográficos do Estado de São Paulo de 1991 e 2000.

Crescendo somente 0,39\% ao ano, a sub-região de Andradina, lócus de uma maior proporção de pastagens e do único grande frigorífico presente na Região Administrativa de Araçatuba, é a porção do espaço geográfico regional que mais contribuiu para que a região como um todo declinasse em sua proporção frente à população total do estado de São Paulo. Mantendo grandes áreas de pecuária extensiva, a criação de emprego e renda continuou aquém daquilo possibilitado com a cana-de-açúcar e outras culturas que em seus circuitos produtivos requisitam uma densidade maior de mão-de-obra. Nessa sub-região, o município de Andradina, enquanto pólo centralizador de alguns serviços públicos e agropecuários, supera a quantia populacional de 50.000 habitantes. 
Tabela 24: Distribuição das Aglomerações Humanas na Região de Araçatuba Segundo Classes de População (2000)

\begin{tabular}{|c|c|}
\hline Classes de População & 2000 \\
\hline Até 5 mil & 22 \\
\hline De 5 a 10 mil & 6 \\
\hline De 10 a 20 mil & 4 \\
\hline De 20 a 50 mil & 3 \\
\hline De 50 a 100 mil & 1 \\
\hline De 100 a 200 mil & - \\
\hline De 200 a 500 mil & - \\
\hline Mais de 500 mil & \\
\hline
\end{tabular}

Fonte: FIBGE, Censo Demográfico de 2000.

Sendo 5 dos 7 novos municípios criados na década de 1990 menores que 5 mil habitantes, aumentam no ano 2000 os municípios nessa faixa demográfica.

Tabela 25

Região de Araçatuba

População Urbana, Rural e Taxa de Urbanização (1991-2000)

\begin{tabular}{|c|c|c|c|}
\hline Ano & $\begin{array}{c}\text { População } \\
\text { Urbana }\end{array}$ & $\begin{array}{c}\text { População } \\
\text { Rural }\end{array}$ & $\begin{array}{c}\text { Taxa de } \\
\text { Urbanização } \\
(\%)\end{array}$ \\
\hline 1991 & 577.610 & 72.193 & 87,5 \\
\hline 2000 & 580.749 & 54.790 & 91,3 \\
\hline
\end{tabular}

Fonte: Fundação IBGE, Censos Demográficos 1991 e 2000.

A mão-de-obra requisitada nas atividades rurais, processo que ocorre desde a década de 1960 (Rossini, 1988), passa a residir cada vez mais em áreas urbanas. A partir da disseminação do uso dos modernos maquinários e implementos agrícolas, cada vez menos trabalhadores 
permanentes são requisitados nas propriedades rurais. A figura do caseiro se tornou quase extinta, resistindo no campo, em maior proporção, os agricultores familiares da pecuária leiteira que - em muitos casos consorciando essa atividade com a fruticultura, o plantio de hortifrutigranjeiros e culturas de auto-abastescimento - abastecem a multinacional Nestlé e outros laticínios menores (Espírito Santo, 2005). 


\section{3) Revitalização do Proálcool nos Últimos Anos e Rearticulação do Circuito Produtivo Canavieiro na Região de Araçatuba}

Como retratamos em momentos anteriores deste trabalho, a revitalização do Proálcool no Brasil a partir do final da década de 1990 e principalmente no limiar do novo milênio, conecta-se com a ascensão do preço da gasolina gerada com os conflitos bélicos intensificados na principal região fornecedora de petróleo do mundo: o Oriente Médio ${ }^{62}$.

Mesmo com a introdução da inovação do carro flex fuel ${ }^{63}$, onde se anula praticamente a hipótese de desabastecimento de álcool como o gerado nos fins dos anos 1980 devido aos aumentos da oferta de petróleo e da demanda do açúcar, e com a problemática ambiental acentuada pelos relatórios surgidos no retrato do aquecimento global ocasionado principalmente pela queima dos combustíveis fósseis, compreendemos ser os custos relativos favoráveis ao álcool combustível em relação à gasolina derivada de petróleo os maiores possibilitadores da expansão da lavoura canavieira no Brasil e especificamente na região de Araçatuba. Nessa perspectiva de mudança do paradigma energético mundial, onde vários países do mundo estudam a anexação do etanol como um dos combustíveis alternativos, as projeções realizadas por especialistas apontam o reajuste da produção do álcool brasileiro dos 17,7 milhões de metros cúbicos anuais do ano safra 2006/2007 para 38 milhões de metros cúbicos na safra 2012/2013. Diante da produtividade média apresentada nos níveis técnicos atuais, esse aumento da demanda requererá a expansão da área cultivada com cana-deaçúcar dos atuais 6.200 milhões de ha para aproximadamente 10.500 milhões de ha no ano de 2013 (Toledo \& Salibe, 2007).

\footnotetext{
${ }^{62}$ Em meados de 2003, o preço do barril do petróleo estava valendo ao redor dos 25 dólares; em julho de 2006 atingiu 75 dólares, e no momento atual - segundo semestre de 2008 -, beira os 150 dólares.

${ }^{63}$ Os carros flex fuel são aqueles que a partir da década de 1990 são colocados no mercado pela indústria automobilística. Estes surgem como possibilitadores de reabastecimento tanto com gasolina como com álcool. Quando o preço do álcool é até $75 \%$ o valor da gasolina, esse primeiro produto tem um custo relativo ao consumidor inferior ao do segundo produto: acima dessa percentual, o reabastecimento com a gasolina é mais vantajoso.
} 


\title{
5.3.1) A Desregulamentação do Setor Sucroalcooleiro
} no Atual Período Neoliberal

Já com a reforma administrativa de Collor, uma nova amarração institucional é instaurada na política para o açúcar e o álcool no país: exemplos iniciais foram as extinções do Instituto do Açúcar e do Álcool (IAA) e do Planalsucar no início de 1990 (Bertero, 1991) ${ }^{64}$. Dentro de um contexto de liberalização econômica, mudou-se com sustância o papel do Estado na economia brasileira, onde o planejamento governamental passa a ter um significado “indicativo”. Amparados pela Constituição Federal, esse primeiro governo neoliberal e seus subseqüentes programaram - com adiamentos e a resistência executada pelo lobby do setor - a desregulamentação em diversos elos da cadeia produtiva canavieira, direcionando-o para um novo ambiente organizacional.

Assim, em 1996, com a estabilização da economia atingida através do Plano Real, a concretização daquilo almejado no início da década pelo estamento monetarista estatal (neoliberal) se propõe: - os preços da cana-deaçúcar - inclusive fretes - do açúcar e do álcool ficariam sujeitos aos regimes de preços liberados. Restava ao setor se adaptar ao mercado da livre concorrência, articulando-se para competir entre si ou se juntar para resistir a regulamentação política que desregulamentava suas relações econômicas. Exercendo suas forças através de seus representantes da bancada ruralista, após três adiamentos de sua aplicação, a liberação dos preços passou a vigorar entre 1999 e 2002 (Moraes, 2002).

Segundo Moraes (2000),

\begin{abstract}
"Os diversos adiamentos da liberação do setor sucroalcooleiro, as discussões e participação ativa dos agentes envolvidos, bem como as notícias veiculadas na mídia deixam claro as dificuldades encontradas nesse processo, no sentido de se equilibrar as questões econômicas, ambientais e sociais envolvidas. Devem ser ressaltadas as fortes pressões e contra-pressões dos diversos segmentos envolvidos, seja no sentido de apoio à liberação econômica (requerida pelos produtores mais eficientes, dispostos a enfrentar as
\end{abstract}

\footnotetext{
${ }^{64} \mathrm{~A}$ infra-estrutura dessas duas entidades públicas foram mantidas à serviço do setor. O Planalsucar, por exemplo, deslocou seus laboratórios e pesquisadores para as universidades públicas, que continuaram investindo pesadamente em inovações favorecedoras da cadeia produtiva canavieira.
} 
regras de livre mercado), seja no sentido inverso, o da manutenção do sistema então vigente, no qual a continuidade da produção em regiões comparativamente menos eficientes (nas diversas etapas da cadeia produtiva), ainda depende do apoio governamental" (MORAES, 2000, p. 89).

Para enfrentar esse transitório momento que se coloca como ditame primordial para as negociações multilaterais vigentes em escala global, novos instrumentos de regulação pública das esferas federal, estadual e municipal - Conselho Interministerial do Açúcar e do Álcool (CIMA), Agência Nacional do Petróleo (ANP), Associação dos Municípios Canavieiros do Estado de São Paulo (Amcesp) e outros - surgem para acompanhar e receber as demandas do setor nesse processo. Parte dos empresários, cooperativas, associações, sindicatos e sociedades - muitos já existentes desde a década de 1980 - passa a se fortalecer e dialogar no intuito de pressionar e controlar as mudanças acontecidas com a liberalização dos mercados: Coligação das Entidades Produtoras de Açúcar e Álcool (Cepaal) para o Centro-Sul, União da Agroindústria Canavieira de São Paulo (Unica) para o estado de São Paulo e União das Destilarias do Oeste Paulista (UDOP) para Araçatuba e seus arredores são alguns exemplos de entidades empresariais encorpadas politicamente nessa atual fase da política econômica agrícola brasileira.

Financiamentos passam a ser buscados com a emissão de papéis das empresas no mercado financeiro para ocupar o espaço gerado com a escassez de dinheiro público ${ }^{65}$. Instituições financeiras de atores do setor como a Brasil Álcool S/A e a Bolsa Brasileira de Álcool (BBA) também surgem nessa recente formatação organizacional para auto-regular os preços agora liberalizados. Investidores americanos, europeus, japoneses e de muitas outras nacionalidades estrangeiras ${ }^{66}$ - pessoas físicas e jurídicas

\footnotetext{
${ }^{65}$ Contudo, o Banco Nacional de Desenvolvimento Econômico e Social (BNDES), mesmo com o fim dos subsídios estatais, tem direcionado - com pequenas taxas de juros - financiamento barato em quantidade expressiva para o setor sucroalcooleiro. O que diferencia a atuação do Estado das primeiras fases do Proálcool é que o crédito não é farto e nem subsidiado. Dessa forma, há os que dizem que muitos atores ainda têm erguido usinas e destilarias no momento atual sem retirar, de antemão, um centavo do próprio bolso.

${ }^{66}$ A lista de estrangeiros interessados na cana-de-açúcar é longa. Inclui o megainvestidor George Soros, o controlador da Microsoft, Bill Gates (dono da maior fortuna do mundo) e os sócios do Google, Sergey Brin e Larry Page. Multinacionais do agronegócio, como a Bunge, já ensaiam os primeiros passos na
} 
(empresas) - anexam capitais na requerente expansão da atividade canavieira com os aumentos das demandas de açúcar no mercado internacional e de álcool combustível no mercado interno e externo. Barreiras às entradas nos negócios do setor são cada vez maiores devidos aos altos volumes de capitais fixos exigidos com a grande intensidade de inovações mecânicas, físico-químicas e biológicas instaladas e precisadas pelas tecnologias de informação em todos os elos da cadeia produtiva ${ }^{67}$.

\section{Foto 45: Sala de Comando Informatizado na Usina Equipav Promissão (SP)}

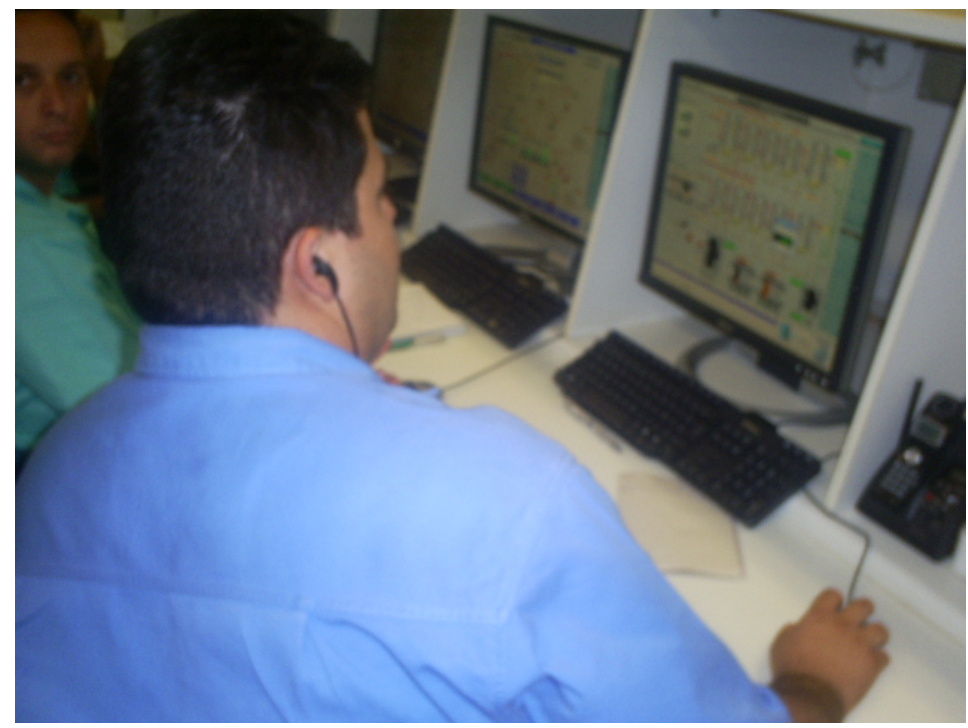

Fonte: Bini, 2008.

direção do setor. Até o presidente americano, George W. Bush, cuja campanha eleitoral foi financiada em parte pela indústria do petróleo, não esconde as qualidades do programa brasileiro do etanol. Em 2004, o primeiro-ministro japonês também visitou plantações paulistas de cana. Atualmente, há negociações entre a empresa de investimentos Kidd \& Company, dos EUA, e a Cooperativa dos Produtores de Cana-deAçúcar de Naviraí (MS), a Coopernavi. A compra, segundo a imprensa da região, envolveria cerca de 260 milhões de reais. No que se refere em específico aos japoneses, os recursos do Japan Bank International Corporation, de US\$ 350 milhões, e do Banco Nacional de Desenvolvimento Econômico e Social (BNDES), de US\$ 300 milhões, serão destinados, em parte, para a instalação de novas usinas e destilarias, infra-estrutura logística, expansão das áreas para plantio de cana e estocagem do álcool que deve ser produzido para exportação exclusiva para o Japão.

${ }^{67}$ Buscando profissionalizar suas gestões, usinas de álcool e açúcar têm intensificado a introdução dos sistemas de gestão empresarial integrado (sigla ERP em inglês), onde softwares “caseiros” - ou melhor, de produção local, regional e nacional - estão sendo trocados por modernas formatações das multinacionais alemã SAP e americana Oracle, o que representa um encaminhamento aprofundado da unicidade técnica e convergência dos momentos característica do período em que vivemos (Santos, 1994). 
Diversificação de produtos derivados (açúcar líquido, levedura, bagaço e outros), verticalizações ${ }^{68}$, fusões e aquisições concentram, dia após dia, em poucas mãos, a atividade canavieira (Mannarelli Filho, 2003), demonstrando a competitividade vigorante principalmente nos últimos 10 anos. No caso de empresas de gerência tipicamente familiar e de capitais regionais, acostumadas com escalas pouco competitivas e uma linha de produtos limitada à produção do açúcar ou do álcool - situação alimentada por longos anos de proteção estatal e agravada pelas falhas de mercado e pela instabilidade macroeconômica - têm perdido participação no setor, em especial pela venda de seus ativos às empresas que flexibilizaram suas gestões, anexaram inovações ou para novos atores - principalmente de capitais internacionais - que vislumbram altos retornos com volumosos investimentos em parques produtivos e abertura de canaviais (Bini, 2003; Gomes; 2007).

Legislações vislumbrando a atenuação da problemática ambiental "pipocam" em diferentes países do mundo, colocando a obrigatoriedade do adicionamento de percentuais variados de álcool anidro à gasolina (Brasil, Índia, China, Canadá, Estados Unidos e União Européia já aplicam a adição e a China discute essa imposição para os próximos anos) e do álcool hidratado para a constituição de suas frotas de flex fuel (Argentina e Japão). São normas para o funcionamento da territorialidade em diversos pontos do mundo que apresentam o etanol como um dos principais paradigmas alternativos aos combustíveis derivados do petróleo. São rearranjos que colocam os fragmentos espaciais do território brasileiro receptores da expansão demandante pela cadeia produtiva canavieira mesmo sob novos conteúdos - como uma totalidade parcial mais intensa da totalidade-mundo.

\footnotetext{
${ }^{68}$ A Cosan, maior empresa de açúcar e álcool do país, com a compra da Esso do Brasil declarada por R\$ 1,371 bilhão em 24 de abril de 2008, pretende se tornar o primeiro player de energia renovável explorando desde o plantio da cana-de-açúcar até a distribuição e comercialização de combustíveis no varejo e atacado.
} 
Retratando esse processo, Torquato \& Perez (2006) mostram o crescimento da exportação de álcool do Brasil nos anos recentes:

“As exportações brasileiras de álcool acumularam o total de 5,6 milhões de toneladas no período de janeiro de 1996 a julho de 2005, tendo evoluído de 294,08 mil toneladas em 2001 para 1,9 milhão de toneladas em 2004 e já tendo ultrapassado um milhão de toneladas nos primeiros sete meses de 2005. Japão, Índia, Holanda, Coréia do Sul, Estados Unidos, Suécia, Jamaica e Nigéria, em conjunto, importaram 78\% da quantidade e 73,4\% do valor do álcool brasileiro no período 1996 a julho de 2005. Costa Rica, México e Turquia, com participações que variaram entre 3,4\% e 2,1\%, completaram o quadro dos onze países principais importadores desse combustível produzido no Brasil. Vale salientar que as importações feitas por alguns países como: Jamaica, Costa Rica, Trinidad e Tobago e El Salvador, em grande parte, se destinam à reexportação para os EUA, utilizando o acordo preferencial de comércio assinado em 1983 entre este país e os países da bacia caribenha, que oferece livre acesso àquele mercado para alguns produtos oriundos desses países. O acordo em questão, o Caribbean Basin Trade Partnership Act of 2000, foi renovado em 2000.” (TORQUATO \& PEREZ, 2006, p.20-21).

Diante dessa ampliação da divisão internacional do trabalho acarretada pelo aumento exponencial do intercâmbio no setor sucroalcooleiro, regiões e localidades antes tradicionais em outras culturas agropecuárias mudam suas tessituras, anexando em seus territórios conteúdos técnicos desse circuito espacial de produção cada vez mais globalizado. 


\subsection{2) A Expansão Canavieira na Região de Araçatuba nos Anos 2000 e}

\section{Algumas Implicações Sócio-Espaciais}

Com a inexistência de áreas para a extensão dos canaviais em contigüidade aos já existentes na região de Ribeirão Preto e nos terrenos de declividade que impossibilitam o corte mecanizado nas outras regiões tradicionais como Piracicaba, o oeste paulista, igual à década de 1980, apresenta-se - com Araçatuba se fortalecendo enquanto centralidade política do setor - como o fragmento do território paulista mais propício para o aprofundamento da anexação de objetos e ações do circuito espacial produtivo canavieiro ${ }^{69}$.

Possuidor de terrenos propícios ao corte mecanizado de alta produtividade (que é 30\% mais barato que o corte manual feito por trabalhadores formalmente registrados), o oeste paulista surge novamente apresentando as melhores possibilidades de custos relativos na contigüidade às regiões tradicionais: a baixa ondulação do planalto ocidental à margem esquerda na Bacia Hidrográfica do Rio Paraná condiciona ao setor atingir as metas médias requisitadas pelas novas normas ambientais implementadas pelo governo estadual ${ }^{70}$.

Sendo assim, a partir de 2001, quando se vislumbra a decolagem dos preços do petróleo devido à intensificação dos conflitos no Oriente Médio, projetos de usinas e anexação de canaviais para a produção de álcool

\footnotetext{
${ }^{69}$ Nacionalmente, áreas mecanizáveis no Paraná, Mato Grosso do Sul, Minas Gerais e Goiás têm recebido investimentos propiciadores da instalação de objetos e ações do circuito produtivo canavieiro.

${ }^{70}$ Fechando o cerco às queimadas nos canaviais - evento usado como argumento principalmente pelos países da Comunidade Européia lançar barreiras não-alfandegárias ao etanol brasileiro - as lideranças políticas paulistas têm negociado com o setor se fazer o uso direto do corte mecanizado nas áreas em expansão do Oeste Paulista. Através de protocolo de intenções lançado em maio de 2007, o governo tucano de José Serra convenceu a grande maioria dos usineiros de entidades do porte da Unica e da Udop a antecipar a data prevista para o fim das queimadas no estado de São Paulo. Com isso, antecipou-se as normatizações impostas pela lei 11.241 de 2003, adiantando de 2021 para 2014 o prazo para a eliminação da queimada da cana-de-açúcar nos terrenos com declividade até $12 \%$ e expandindo o percentual de cana não queimada, em 2010, de 50\% para 70\%. Nos terrenos com declividade acima de $12 \%$, o prazo final para a eliminação da queimada se antecipou de 2031 para 2017, expandindo o percentual da cana não queimada, em 2010, de 10\% para 30\%. A não utilização da queima da cana-de-açúcar nas colheitas das áreas de expansão de canaviais, como as que acontecem recentemente na região de Araçatuba, foram acordadas no protocolo entre o governo estadual e o setor (www.ambiente.sp.gov.br/etanolverde; Acesso Disponível em 26/09/2007). Segundo dados divulgados em março de 2008 pela Secretaria do Meio Ambiente do estado de São Paulo, na safra de 2007, dos 4,5 milhões de hectares de cana paulista, 110 mil hectares "já” foram colhidos sem queimadas.
} 
combustível começam a se tornar atrativos à elite econômica regional. Tradicionais pecuaristas que na década de 1980 resistiram ao projeto sucroalcooleiro não suportam as ofertas dadas pelas usinas ao arrendamento de suas terras. Adicionado ao declínio do preço da arroba vigorante nessa primeira metade da década, inicia-se um processo mais intenso de deslocamento da boiada para pastagens do Centro-Oeste e Norte do país ${ }^{71}$. Do biênio 2000/2001 ao 2003/2004, 15 novas unidades produtivas do oeste paulista e Centro-Sul do país se incorporam à centralidade adquirida por Araçatuba nesse novo momento do setor.

Intermediados pelo lobby da UDOP - que em meados dessa década passa a se denominar "União dos Produtores de Bioenergia” -, investidores produtivos e financeiros nacionais e internacionais, em parceria com as administrações públicas municipais, estadual e federal começam a implementar a anexação no espaço geográfico da região de Araçatuba e entorno novos tentáculos constituidores dos sistemas de objetos e ações do circuito econômico canavieiro.

\footnotetext{
${ }^{71}$ Algumas das mudanças que afligem sobre o setor pecuário na região de Araçatuba nos anos 2000 retrataremos em momento posterior desse trabalho.
} 


\section{Mapa 5: Área de Influência sob Pretensão de Representatividade pelos Usineiros da Região de Araçatuba}

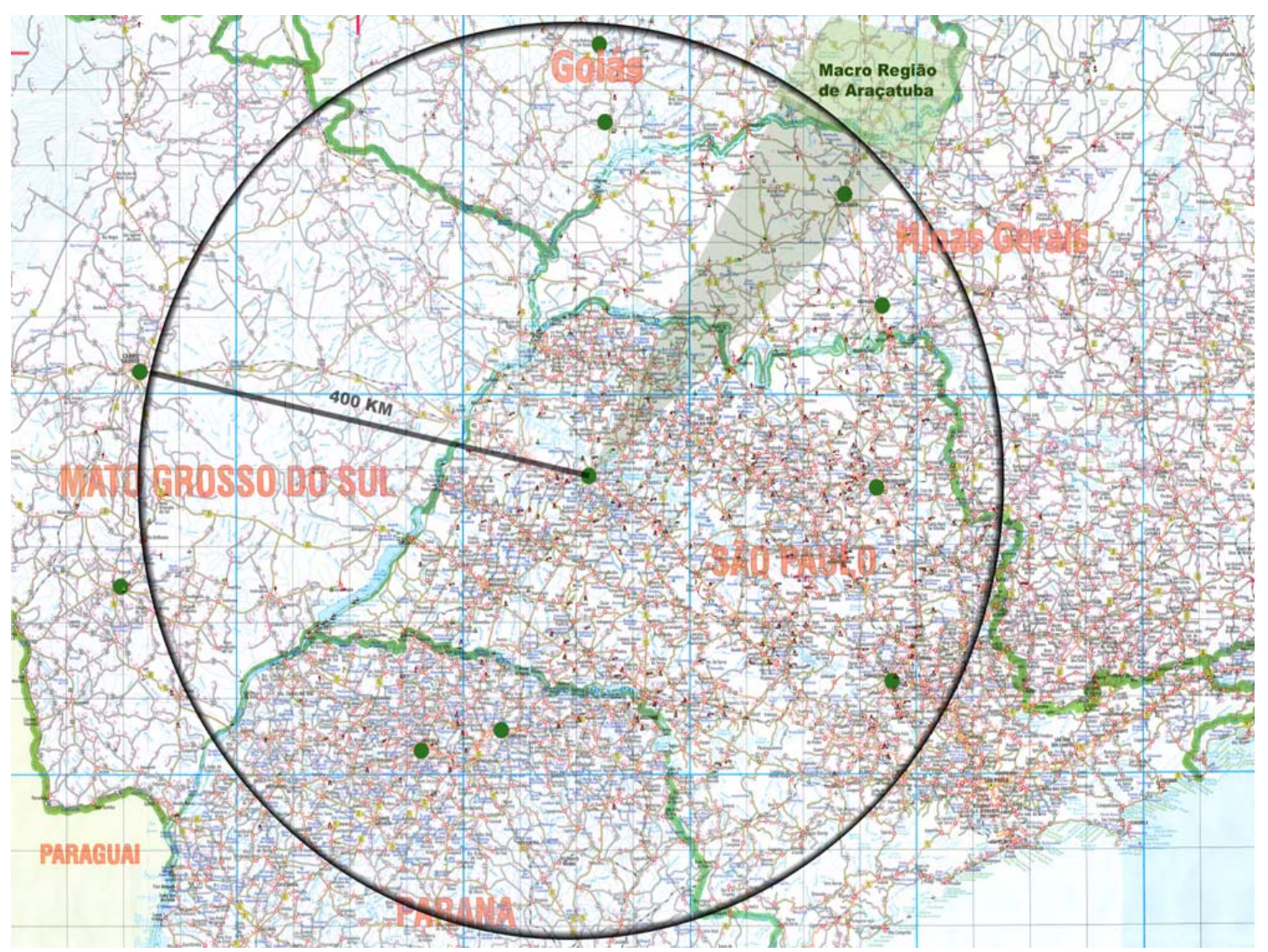

Fonte: Toledo \& Salibe, 2007.

Esse processo se avoluma na segunda metade da década dos anos 2000 com o aumento da demanda de etanol no mercado interno desencadeado pela popularização do carro flex fuel e pelas perspectivas de sua anexação como commoditie no comércio internacional. Assim, entre os biênios 2004/2005 e 2006/2007, quatorze novas usinas de açúcar e álcool são acopladas ao espaço geográfico do oeste paulista por grupos já presentes no setor ${ }^{72}$. Através de créditos conseguidos com bancos (como o BNDES, o Unibanco, o Bradesco e outros), investidores nacionais e estrangeiros e via

\footnotetext{
${ }^{72}$ Essa expansão do setor sucroalcooleiro nesse momento recente se caracteriza pela concentração cada vez maior das unidades produtivas nas mãos de poucos atores. São esses poucos grupos que, pelo balanço positivo de suas atividades, têm recebido a aprovação de novos projetos financiados pelo BNDES e principalmente pelo capital financeiro internacional. Alguns desses exemplos que atuam na região araçatubense são os grupos Biagi/Humus, Clealco, Cosan, Exxel, Petribú e Santa Elisa.
} 
operações de pré-pagamento (recebe o pagamento do produto e o entrega depois de alguns anos) ${ }^{73}$ a construção dessas unidades produtivas tem mudado a dinâmica sócio-espacial regional.

\section{Foto 46: Usina Benalcool (Grupo Cosan) em Bento de Abreu (SP)}

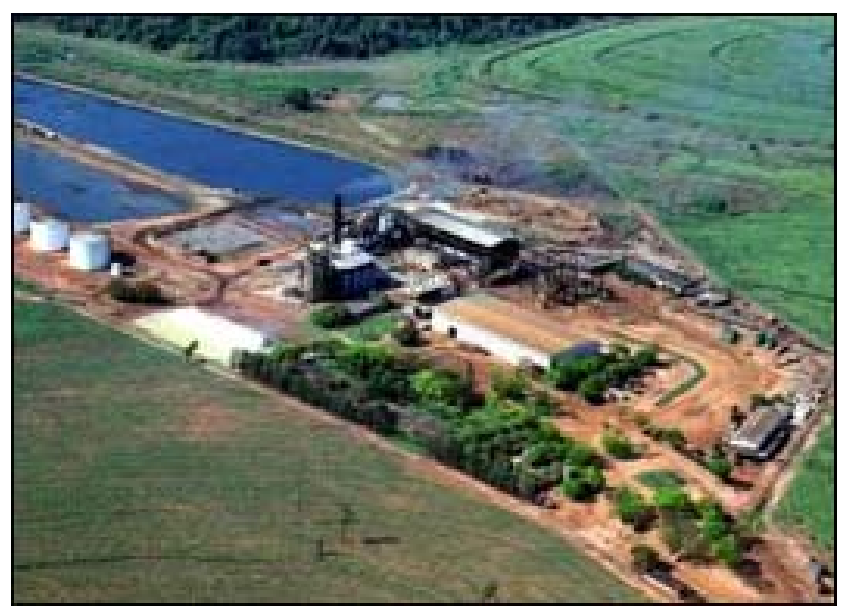

Fonte: http://www.cosan.com.br/unidades_benalcool.aspx; Acesso Disponível em 02/09/2008.

Dessa forma, a Região Administrativa de Araçatuba, como uma das ofertantes de parte da cana processada pelas usinas do oeste paulista, aumentou sua área de produção de 180.399 hectares em 2001 para 251.902 hectares em 2006 (Camargo et al., 2008). A partir dos números do Banco de Dados do Instituto de Economia Agrícola (IEA), em todo o oeste do estado de São Paulo - que definimos como a somatória das Regiões Administrativas de Araçatuba, Presidente Prudente e São José do Rio Preto - a ocupação da cultura da cana-de-açúcar passou dos 500.625 hectares em 2001 para 1.466.862 hectares em 2007: passou de aproximadamente 24\% para 30\% da área de cana-de-açúcar estadual.

\footnotetext{
${ }^{73}$ Folha da Região, 30/08/2006, pág. A5.
} 
Tabela 26 - Evolução da Área Total Plantada com Cana-de-Açúcar para Indústria, por Região Administrativa do Estado de São Paulo, 1990-2007 (em hectares).

\begin{tabular}{|c|c|c|c|c|}
\hline $\begin{array}{c}\text { Divisão } \\
\text { Regional }\end{array}$ & 1990 & 1995 & 2000 & 2007 \\
\hline S J Rio Preto & 150.660 & 180.465 & 201.526 & 620.058 \\
\hline Campinas & 405.356 & 469.032 & 429.922 & 591.443 \\
\hline Franca & 128.290 & 274.530 & 319.887 & 501.897 \\
\hline Araçatuba & 116.549 & 162.396 & 197.329 & 498.130 \\
\hline Rib. Preto & 354.322 & 435.072 & 435.453 & 465.093 \\
\hline Bauru & 256.137 & 321.428 & 286.840 & 449.418 \\
\hline Marília & 203.784 & 210.177 & 220.001 & 396.986 \\
\hline Barretos & 64.883 & 151.961 & 182.174 & 373.909 \\
\hline Central $^{74}$ & 231.362 & 283.007 & 314.565 & 353.178 \\
\hline P. Prudente & 73.875 & 82.452 & 101.750 & 348.704 \\
\hline Sorocaba & 122.749 & 135.683 & 137.364 & 230.784 \\
\hline S. J. Campos & 3.182 & 1.662 & 1.560 & 1.721 \\
\hline Registro & 95 & 270 & 30 & 129 \\
\hline São Paulo & 475 & 438 & 225 & 90 \\
\hline B. Santista & 5 & 1 & 74 & 31 \\
\hline Estado & 2.111 .709 & 2.708 .574 & 2.828 .700 & 4.831 .574 \\
\hline
\end{tabular}

Fonte: Banco de Dados do Instituto de Economia Agrícola (IEA).

\footnotetext{
${ }^{74}$ A Região Administrativa Central compreende as Regiões de Governo de Araraquara e São Carlos.
} 
Mapas 6 e 7: Relação das Áreas de Ocupação de Cana-de-açúcar no

\section{Centro-Sul do Brasil (2003-2008)}
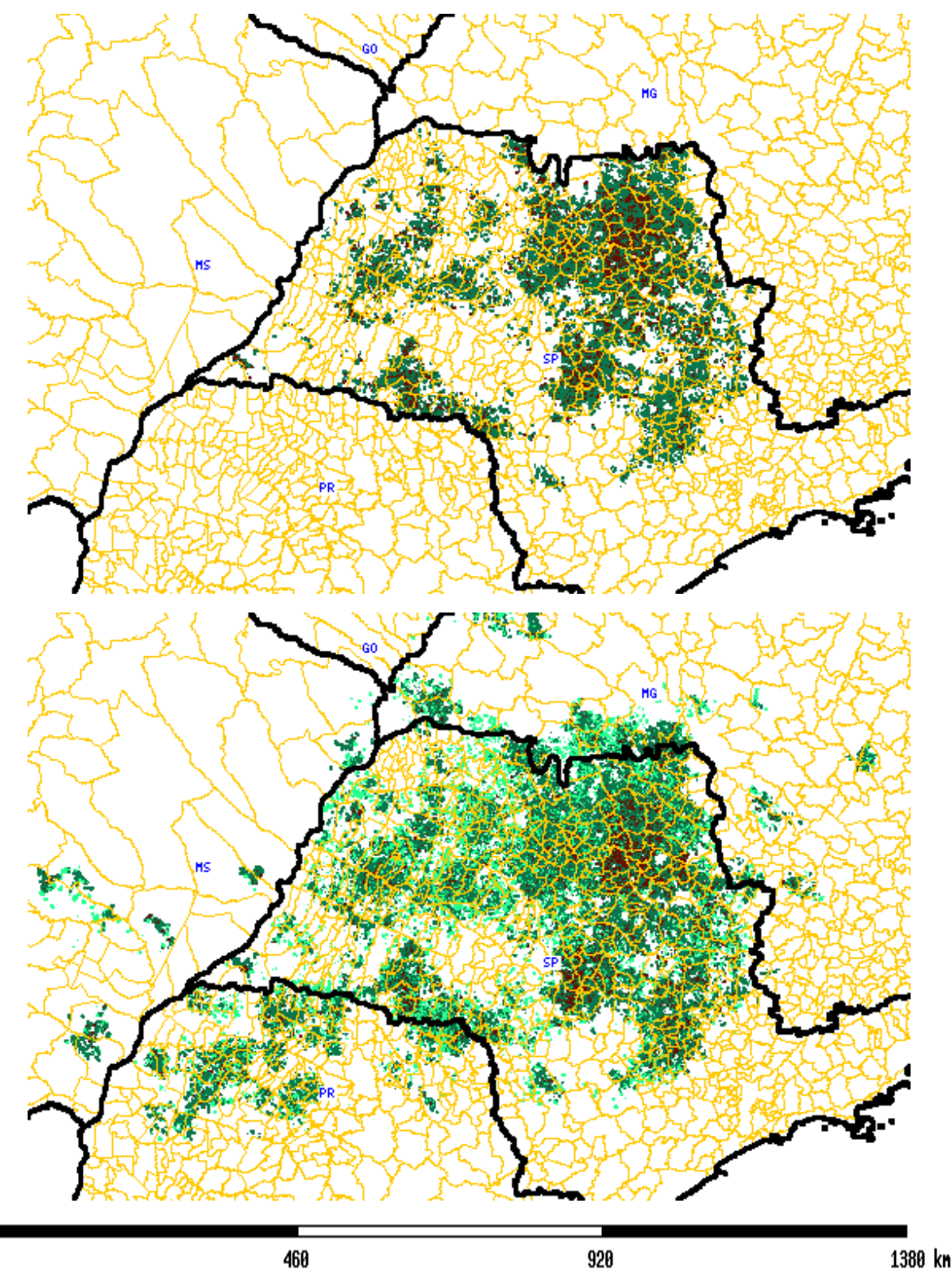

Legenda: Para os dois momentos, em marrom temos as áreas de cana em reforma, em verde escuro temos as áreas de plantio antigo e em verde claro estão representadas as novas áreas de plantio.

Fonte: http://www.dsr.inpe.br/mapdsr/frame.jsp; Acesso Disponível em 02/09/2008. 
Ocupando principalmente áreas de pastagens acompanhando rodovias e estradas - localizações geográficas possibilitadoras de menores custos de transporte entre os canaviais e as usinas - ao simples observador se passa a sensação comumente relatada de que a região está virando um "mar de cana",75.

\section{Foto 47: Canaviais Margeando Rodovia Vicinal na Região de Araçatuba $^{76}$}

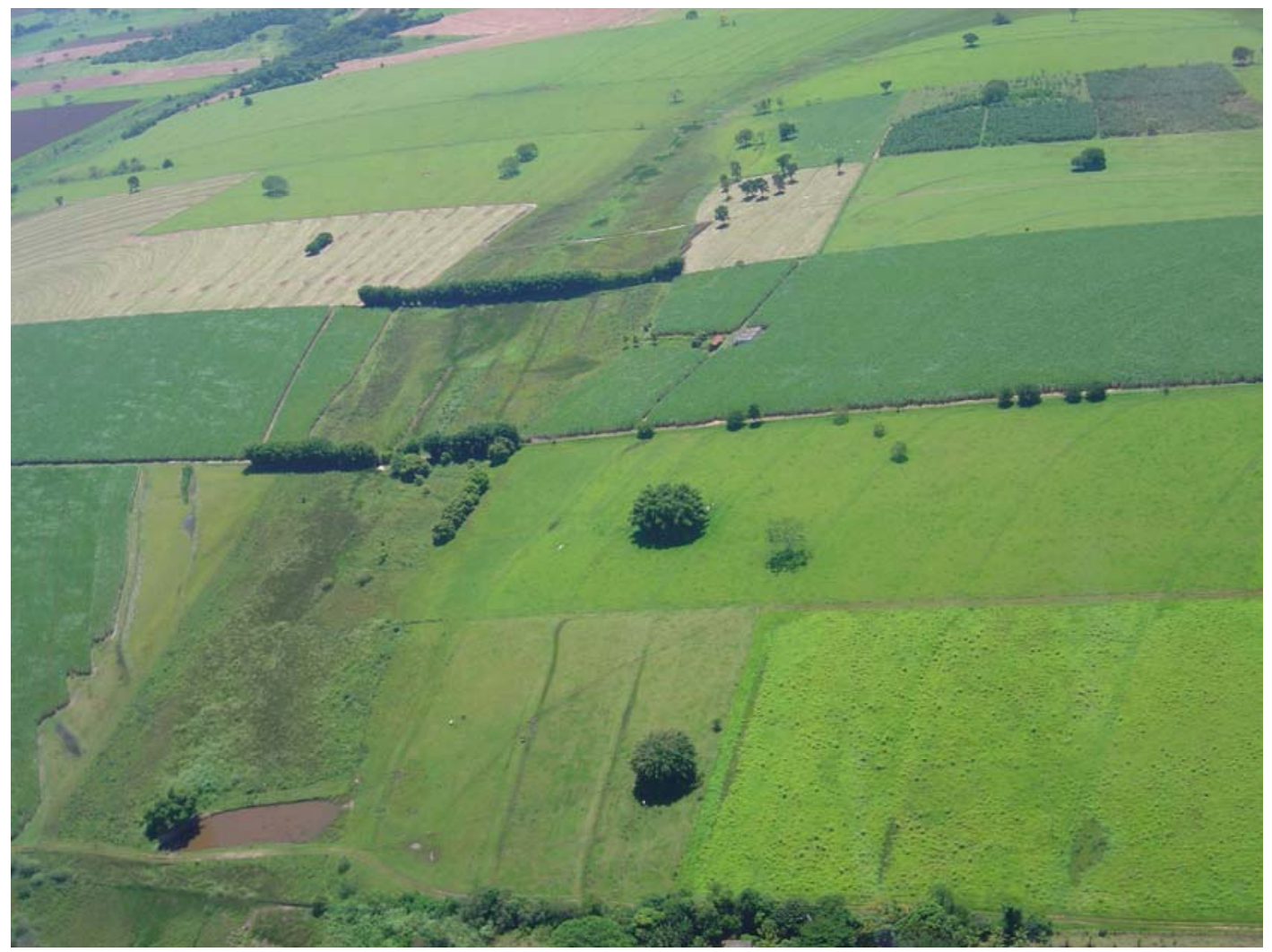

Fonte: Udop, 2007.

\footnotetext{
${ }^{75}$ Porém, mesmo com essa expansão da lavoura canavieira, são as pastagens que ainda hegemonizam a ocupação do espaço geográfico regional. Presentes ainda em grande proporção nos fundões longe das vias de transporte há uma percepção de que sua área regional tenha diminuído mais do que a realidade concreta.

${ }^{76}$ Pode-se observar no mapa, perpendicular à vicinal, fundo de vale com curso de água quase totalmente assoreado. Nas duas margens da estrada também podemos visualizar pastagens sub-ocupadas, situação característica da pecuária extensiva regional.
} 
Considerando que o acordo entre os usineiros e o governo do estado de São Paulo proibindo as queimadas sobre as novas áreas de canaviais antes da colheita passou a vigorar somente a partir de sua assinatura - que ocorreu em junho de 2007 -, nesse intervalo (2001-2007) de acentuado aumento do número de áreas transferidas para a cultura canavieira, o corte foi feito prioritariamente de forma manual. Sendo assim, não existindo na região de Araçatuba mão-de-obra disponível para a colheita dos canaviais, migrantes de várias regiões do país - principalmente dos estados do Nordeste - se disponibilizaram, frente ao aliciamento dos "agenciadores de mão-de-obra"77, para a realização do corte manual da cana-de-açúcar.

\section{Foto 48: Queimada em Canavial na Região de Araçatuba}

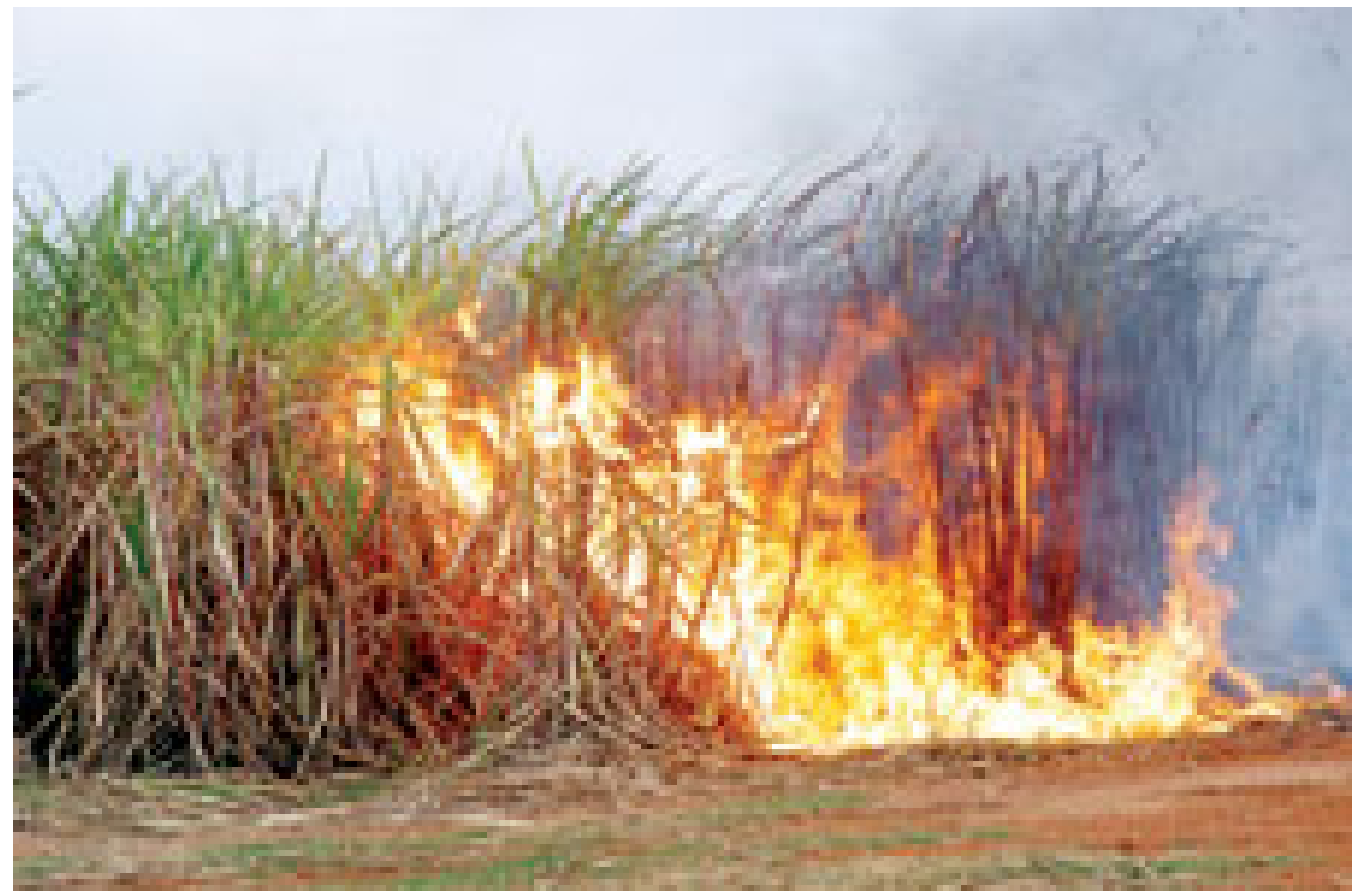

Fonte: Folha da Região, 31/05/2007 (http://www.folhadaregiao.com.br/noticia?69109; Acesso Disponível em 02/09/2008).

\footnotetext{
${ }^{77}$ Nome moderno dos tradicionais “gatos”.
} 
Todo esse processo contribuiu para um aumento populacional mais vigoroso na região entre 2000 e 2007, sendo a sub-região de Araçatuba a mais afetada como podemos visualizar na tabela abaixo:

Tabela 27

Região de Araçatuba

População e Taxas Anuais de Crescimento Populacional por Sub-Região 2000-2007

\begin{tabular}{|c|c|c|c|}
\hline $\begin{array}{c}\text { SUB- } \\
\text { REGIÕES }\end{array}$ & 2000 & 2007 & $\begin{array}{c}\text { Taxa Anual de } \\
\text { Crescimento 2000-2007 } \\
(\%)\end{array}$ \\
\hline Araçatuba & 464.339 & 525.807 & 1,89 \\
\hline Andradina & 171.200 & 182.420 & 0,93 \\
\hline Total & 635.539 & 708.227 & 1,41 \\
\hline \% do Estado & 1,71 & 1,77 & 1,10 \\
\hline
\end{tabular}

Fonte: FUNDAÇÃO IBGE, Censo demográfico do Estado de São Paulo de 2000 e Contagem da População de 2007.

Crescendo 1,41 \% ao ano - taxa maior que a do estado de São Paulo como um todo (que cresceu 1,10 \% ao ano) -, a população da Região Administrativa de Araçatuba aumenta sua representação na população paulista no decorrer desses setes anos analisados: passa de um percentual de 1,71 \% para 1,77 \% da população total do estado de São Paulo. É uma reversão do ciclo de esvaziamento populacional que observamos de 1950 a 2000 !

Dos 43 municípios integrantes da delimitação regional, somente 5 sendo esses de pequenas proporções ( 3 menores que 5 mil habitantes e 1 menor que 10 mil habitantes) tiveram suas populações diminuídas: Lavínia, Rubiácea e Turiúba, pertencentes a essa lista, mesmo obtendo declínio demográfico, vislumbraram em suas áreas urbanas reajustes do número de moradores. Como todos os municípios da Região Administrativa, o peso deficitário na densidade demográfica se intensificou nas áreas rurais: 
estando os cortadores de cana sobrevivendo sob o regime de trabalho volante, estes densificam principalmente as áreas urbanas, onde moram em alojamentos, cortiços ou casas na perifeira das cidades ${ }^{78}$.

\section{Foto 49: Alojamento de Cortadores de Cana Migrantes na Região de Araçatuba}

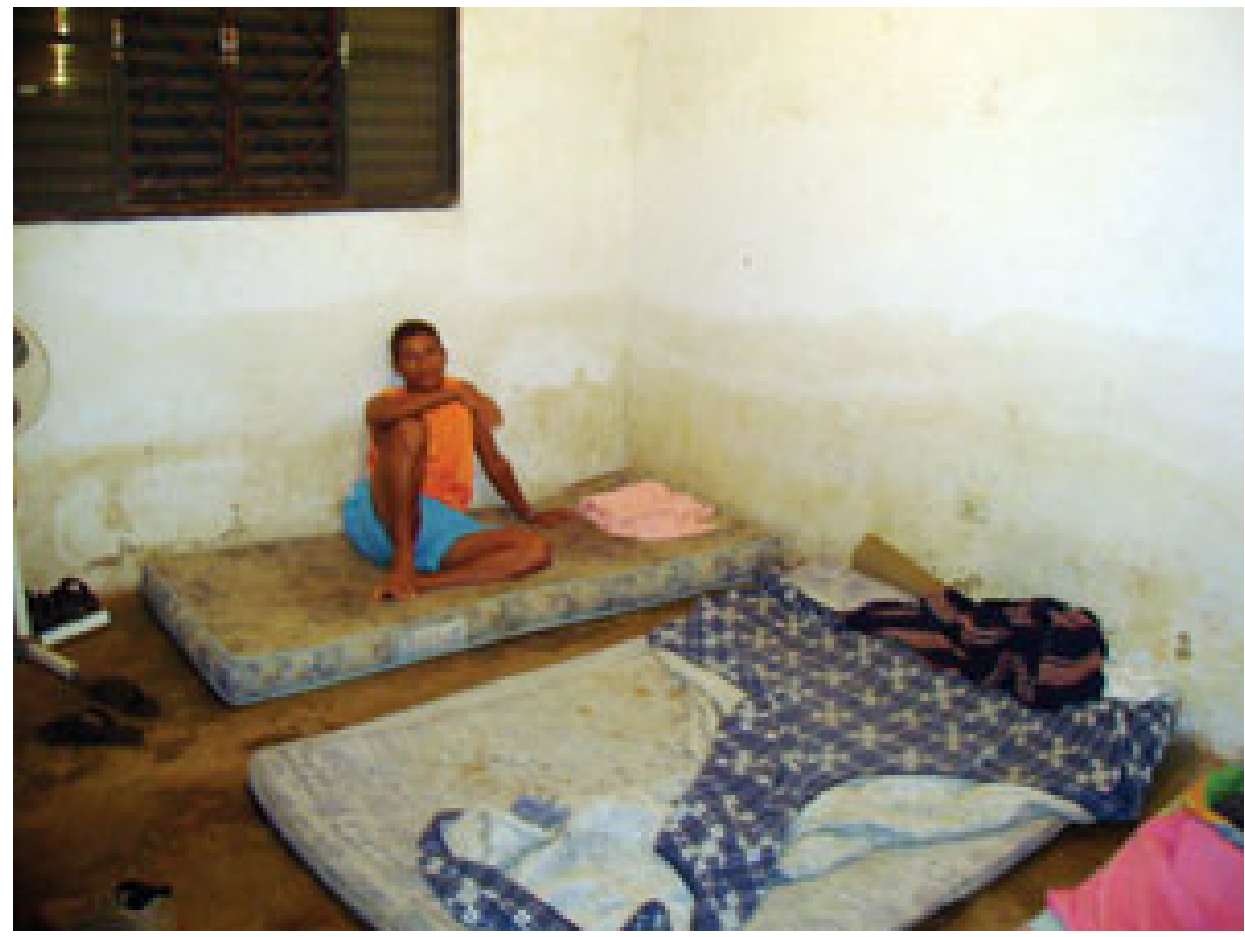

Fonte: Folha da Região, 01/06/2008 (http://www.folhadaregiao.com.br/noticia?92322; Acesso Disponível em 02/09/2008).

\footnotetext{
${ }^{78}$ Uma minoria dos trabalhadores mora em alojamentos construídos pelas usinas no meio dos canaviais nas áreas rurais.
} 
Assim, analisando os dados das Informações dos Municípios Paulistas (IMP) do Seade $^{79}$, retratamos a acentuação do nível de urbanização das localidades estudadas:

Tabela 28

Região de Araçatuba

População Urbana, Rural e Taxa de Urbanização (2000-2007)

\begin{tabular}{|c|c|c|c|}
\hline Ano & $\begin{array}{c}\text { População } \\
\text { Urbana }\end{array}$ & $\begin{array}{c}\text { População } \\
\text { Rural }\end{array}$ & $\begin{array}{c}\text { Taxa de } \\
\text { Urbanização } \\
(\%)\end{array}$ \\
\hline 2000 & 611.060 & 61.512 & $90,8 \%$ \\
\hline 2007 & 664.889 & 51.394 & $92,8 \%{ }^{80}$ \\
\hline
\end{tabular}

Fonte: Informações dos Municípios Paulistas (IMP), Seade (www.seade.sp.gov.br).

Reflexo desse movimento de reversão que direcionou a região de Araçatuba a uma configuração de crescimento, alguns municípios influenciados pela expansão da lavoura canavieira - ascenderam seus níveis entre as classes de população regional.

\footnotetext{
${ }^{79}$ Como para 2007, até a finalização desse trabalho o IBGE ainda não disponibilizava em seus bancos de dados a divisão da população urbana e rural dos municípios, usamos para a presente análise os dados fornecidos pelo SEADE em seu site (www.seade.sp.gov.br). Sendo assim, devido à diferenciação das metodologias aplicadas pelas duas instituições de pesquisa, a população total no período analisado possui pequenas diferenças.

${ }^{80}$ Com esse percentual gerado principalmente pelo êxodo rural, a região de Araçatuba se aproxima um pouco mais da taxa de urbanização estadual que atinge 93,7\% no ano de 2007.
} 
Tabela 29: Distribuição das Aglomerações Humanas na Região de Araçatuba Segundo Classes de População (2007)

\begin{tabular}{|c|c|}
\hline Classes de População & 2007 \\
\hline Até 5 mil & 21 \\
\hline De 5 a 10 mil & 8 \\
\hline De 10 a 20 mil & 5 \\
\hline De 20 a 50 mil & 2 \\
\hline De 50 a 100 mil & 2 \\
\hline De 100 a 200 mil & - \\
\hline De 200 a 500 mil & - \\
\hline Mais de 500 mil & \\
\hline
\end{tabular}

Fonte: FIBGE, Contagem da População, 2007.

Piacatu, ultrapassando os 5.000 habitantes passa a se enquadrar entre aqueles municípios possuidores entre 5 e 10 mil moradores. Avanhandava superou os 10.000 habitantes, colocando-se na classe de população entre 10 e 20 mil habitantes. Valparaíso, com mais de 20.000 habitantes, ascende à posição daqueles localizados entre 20 e 50 mil habitantes e Birigui, contabilizando 103.394 moradores na Contagem da População de 2007 feita pelo IBGE, alcança o grau de cidade de médio porte, compartilhando cada vez mais com Araçatuba a centralidade do comando dos eventos na hierarquia urbana regional ${ }^{81}$.

\footnotetext{
${ }^{81}$ Araçatuba e Birigui, distantes 10 kilômetros uma da outra, através da instalação de fábricas, comércios e conjuntos habitacionais nas vias de acesso entre elas (Rodovia Marechal Rondon e vicinal Guatambu) tem acelerado suas ligações caracterizadoras de conurbação. Com esses novos fixos anexados, a dinâmica dos fluxos tem apresentado e requerido transformações: o pedido de novas rotatórias no trajeto da Marechal Rondon e o maior número de paradas realizadas pelos ônibus intermunicipais que ininterruptamente circulam entre os dois municípios são exemplos da imbricação cada vez mais intensa entre eles. Contudo, há que se retratar que a complementaridade de comando exercida por Birigui se refere à sua posição como pólo do setor calçadista: sugando grande quantidade de mão-de-obra dos municípios menores em seu entorno para trabalhar em suas fábricas, sua centralidade econômica encarece o custo da força de trabalho na região, competindo com o ascendente setor sucroacooleiro na demanda por mão-de-obra. Daí a necessidade de se recrutar migrantes para trabalhar nos tratos da lavoura canavieira.
} 
Para gerar a fluidez desses novos conteúdos dinamizadores do espaço geográfico regional e evitar estrangulamentos infra-estruturais que impeçam um desempenho desejável dos sistemas de objetos e ações expandidos principalmente pelo circuito espacial de produção do setor canavieiro, grandes investimentos públicos e privados passam a ser direcionados.

O modal rodoviário, sendo o mais utilizado para as ações econômicas da região e especificamente para o escoamento da produção de açúcar e álcool e outros produtos ${ }^{82}$ - ele também serve como principal artéria receptora das mercadorias e pessoas vindas de localidades externas -, tem apresentado problemas sérios em sua manutenção, como a existência de buracos ocasionados, por exemplo, pelo desgaste obtido com o excesso de peso dos caminhões canavieiros. Para reverter essa realidade intensificada com o aumento do uso das estradas regionais provocado pela expansão do circuito espacial de produção canavieiro, o governo do estado de São Paulo, através do Programa Pró-Vicinais ${ }^{83}$, contemplou a Região Administrativa de Araçatuba no segundo semestre de 2007 com R\$ 63 milhões, onde 46 estradas municipais começaram a ser recuperadas, em um total estimado de 381,9 quilômetros ${ }^{84}$.

${ }^{82}$ Para a Cooperativa do Pólo Hidroviário de Araçatuba (COOPERHIDRO), cerca de $90 \%$ das mercadorias regionais são transportadas pelas rodovias.

${ }^{83}$ Lançado em junho de 2007, o programa do governo paulista pretende recuperar aproximadamente 13 mil quilômetros de estradas municipais no estado de São Paulo. Com recursos do Estado, de financiamento externo e de parcerias com prefeituras e a iniciativa privada, a Secretaria do Planejamento, segundo informações oficiais, considerou questões como as interligações entre as vicinais e a malha rodoviária estadual, objetivando a redução dos custos de transporte geradora de desenvolvimento.

84 Além do Pró-Vicinais, existe um projeto de investimento que está contribuindo para manter a circulação no espaço geográfico das estradas rurais da região: é o programa estadual "Melhor Caminho", fundado na administração do governador Mário Covas, em 1997. Sob administração da Secretaria da Agricultura e Abastecimento, o programa tem como objetivo manter as estradas rurais trafegáveis o ano todo, para que os produtores rurais não tenham problemas principalmente para o escoamento de produtos e insumos. 


\section{Foto 50: Estrada Vicinal Nametala Rezek na Região de Araçatuba}

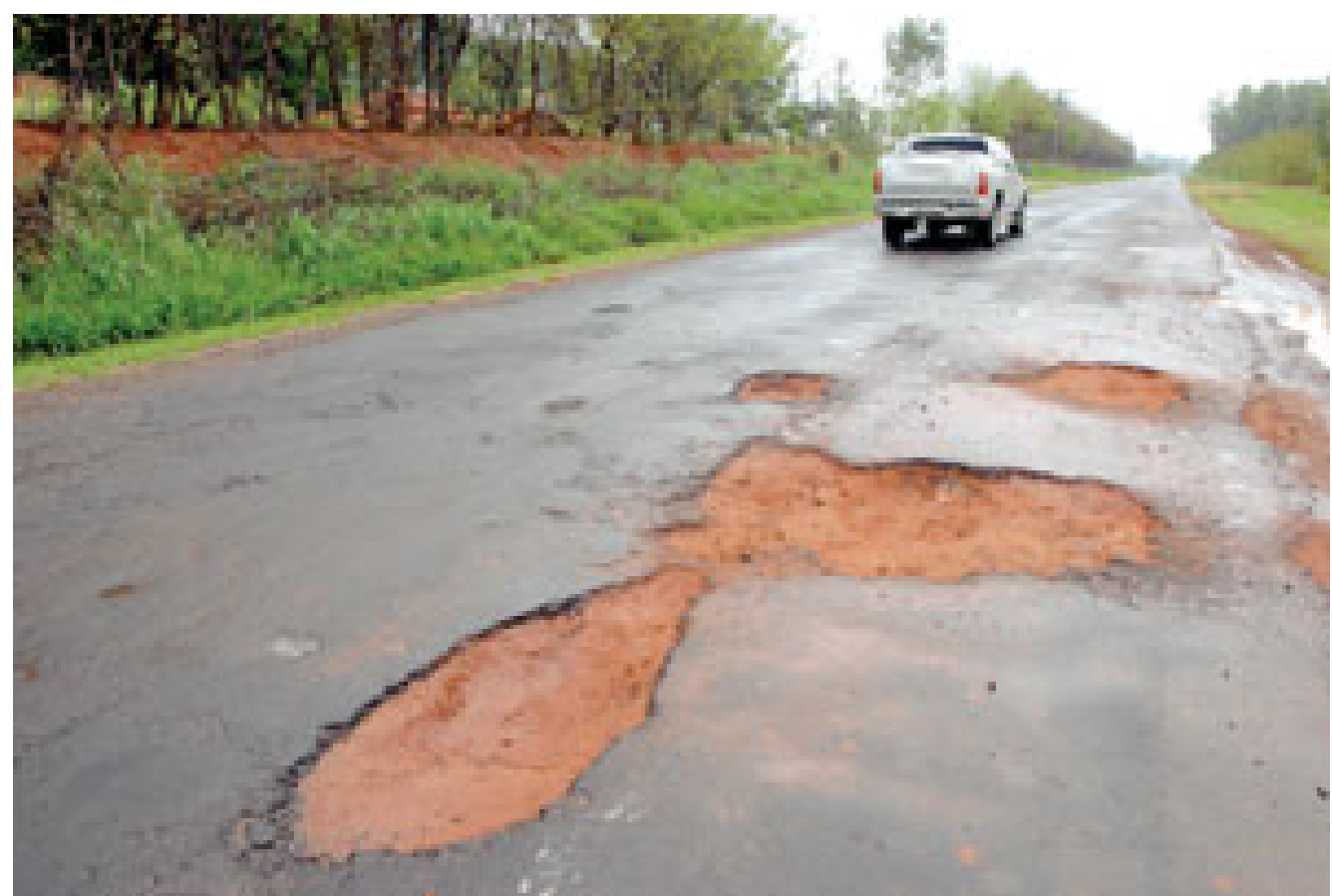

Fonte: Folha da Região, 07/11/2007 (http://www.folhadaregiao.com.br/noticia ?79183\&PHPSESSID=33d7c6c4b0daea77dfde8aa4f5b0f7d7; Acesso Disponível em 03/09/2008).

Enquanto possibilidade colocada em prática pelos planejadores públicos e privados para o transporte de mercadorias na região de Araçatuba, o modal ferroviário aparece com as melhores condições atuais de complementaridade à hegemônica locomoção rodoviária. Sucateada até fins da década de 1990 e pouco movimentada desde então, o trajeto histórico da Estrada de Ferro Noroeste do Brasil (C.E.F.N.O.B) - privatizada em 1996 e renomeada de Ferrovia Novoeste S. A. -, começa a receber nova vitalidade com a retomada do desenvolvimento da região no início do século $\mathrm{XXI}^{85}$. Adquirida pela empresa norte-americana América Latina Logística (ALL) em 2006, tem recebido investimentos condicionados por parcerias com o setor produtivo, comercial e de serviços.

85 De 1996 a 2006, o aumento anual no movimento de cargas via ferrovias no Brasil foi de 5,8\%. Acelerando esse processo de retomada da malha ferroviária nacional entre 2006 e 2007, esse reajuste saltou para 11\%, segundo dados da Associação Nacional dos Transportes Ferroviários (ANTF). 


\section{Foto 51: Trilhos e Vagões na Região de Araçatuba}

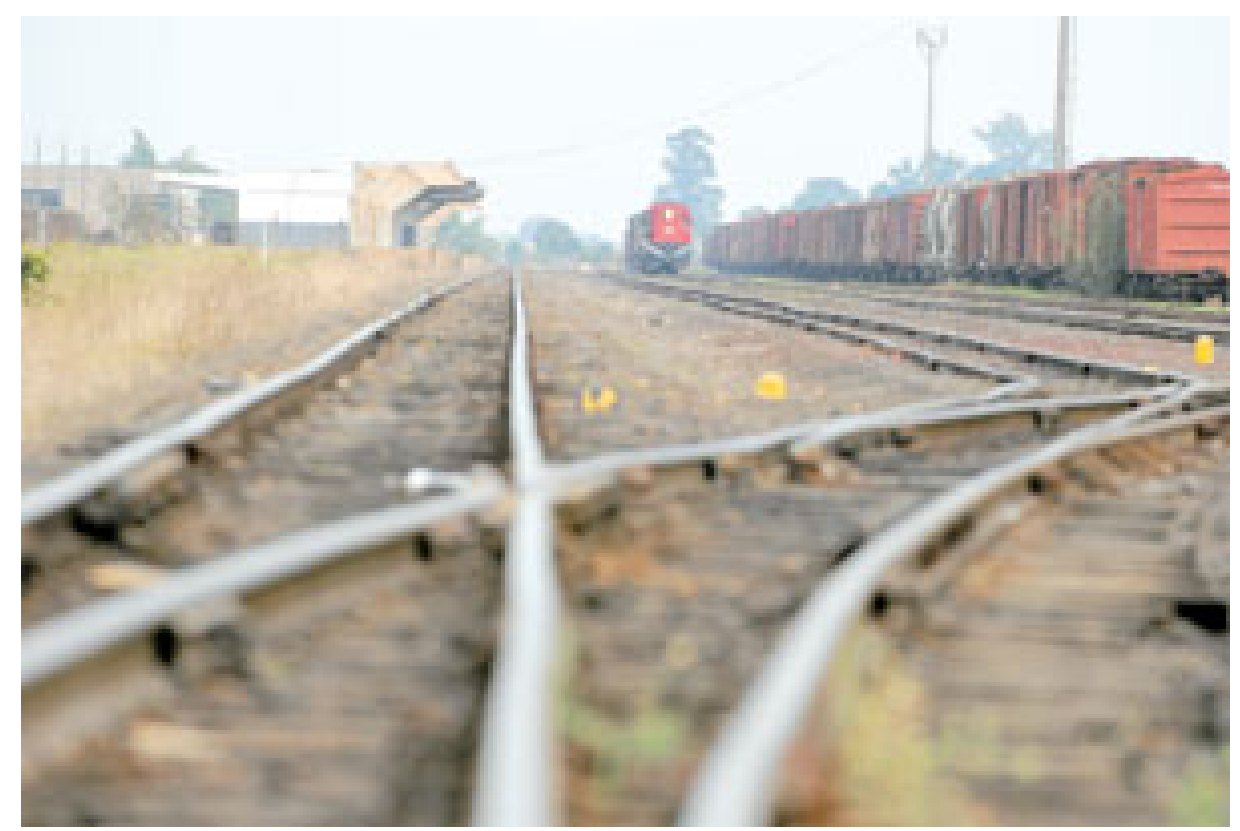

Fonte: Folha da Região, 25/06/2008 (http://www.folhadaregiao.com.br/noticia?93785; Acesso Disponível em 03/09/2008).

Exemplo desses empreendimentos é a utilização cada vez mais intensa dessa malha ferroviária pelo setor sucroalcooleiro. Em 2003, ano do encerramento da construção do terminal rodoferroviário financiado pela multinacional francesa de exportação Sucden, em parceria com as usinas Aralco e Unialco ${ }^{86}$, em Araçatuba, no entroncamento da estrada de ferro com a rodovia Eliezer Montenegro Magalhães, parte do açúcar produzido na região para exportação deixa de ser feito pelo modal rodoviário. Especializada na conexão intermodal, a empresa proprietária do terminal rodoferroviário, Araçatuba Logística (Arlog), faz o transbordo do açúcar produzido em usinas que tenham interesse pelo escoamento alternativo para os trens.

\footnotetext{
${ }^{86}$ Na concretização dessa parceria fundou-se a empresa Araçatuba Logística.
} 


\section{Foto 52: Abastecimento de Açúcar em Vagão}

\section{no Terminal Rodoferroviário Araçatuba Logística}

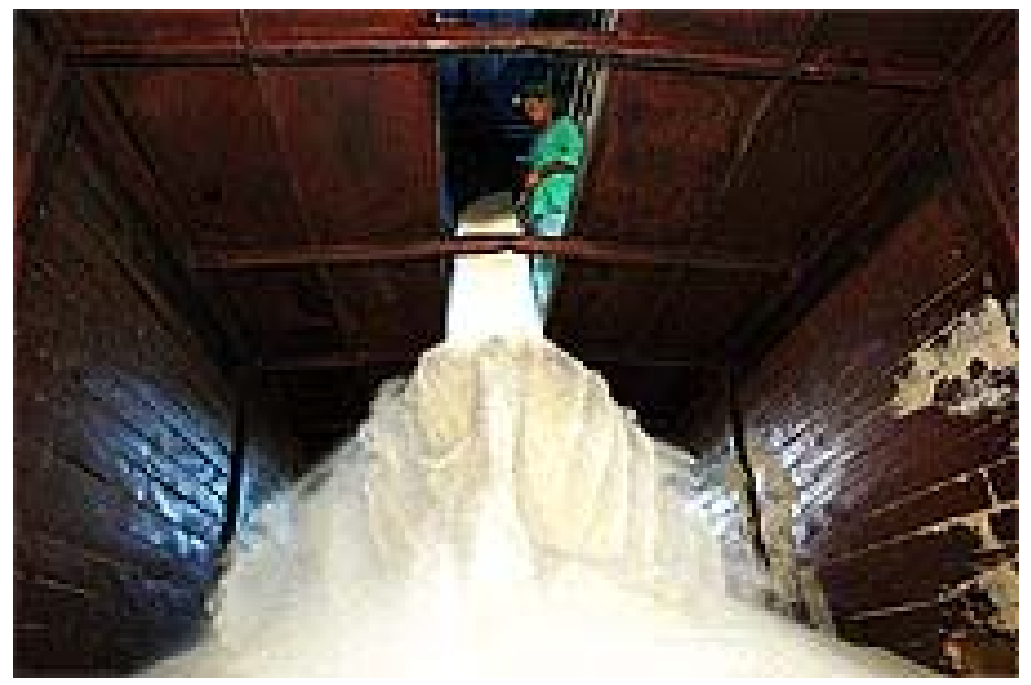

Fonte: Folha da Região, 23/02/2004.

Representando uma economia de 10 \% em relação ao transporte rodoviário de açúcar, a “Arlog pretende investir em um projeto de tancagem de álcool, que demandará recursos na ordem de $R \$ 5$ milhões. (...), hoje, a empresa ${ }^{87}$ já transporta diesel e gasolina de Paulínia para Campo Grande (MS), distribuindo por todo o interior e os vagões retornam vazios” (Folha da Região, 28/09/2007, pág. A5). A pretensão da América Latina Logística (ALL) é realizar o trajeto de volta transportando o álcool utilizando os mesmos vagões ${ }^{88}$. Basta existir neste caminho centros coletores com tanques armazenadores de álcool: é o que a Arlog está planejando construir no terminal rodoferroviário em Araçatuba.

\footnotetext{
${ }^{87}$ Nesse caso, a matéria jornalística se refere à empresa América Latina Logística (ALL), concessionária que administra a malha ferroviária da antiga Estrada de Ferro Noroste do Brasil (C.E.F.N.O.B).

${ }^{88}$ Um gargalo para legitimar esse projeto é o custo da assepssia dos vagões para não retirar a pureza do álcool comercializado.
} 


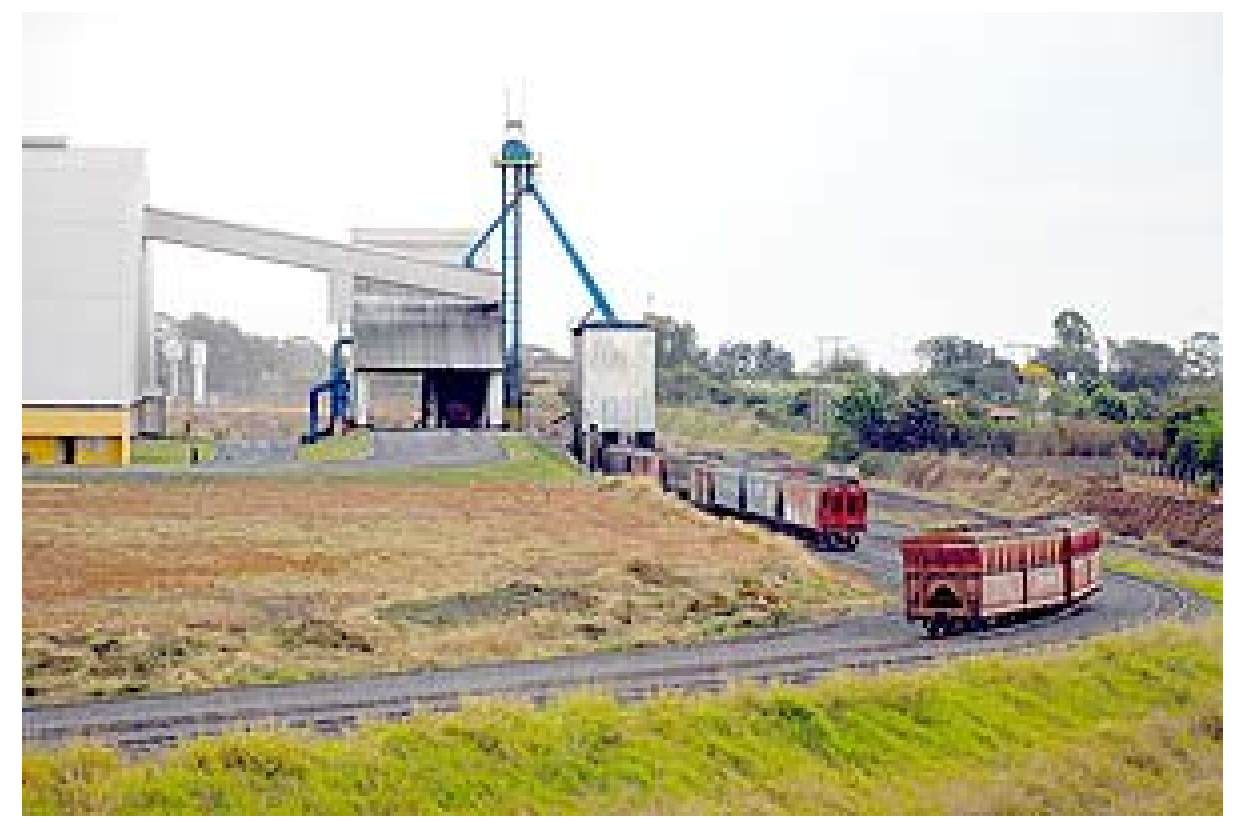

Fonte: Folha da Região, 10/08/2008 (http://www.folhadaregiao.com.br/ noticia?96572\&PHPSESSID=2f1ef7915731d8f; Acesso Disponível em 03/09/2008).

Também com a intenção de evitar gargalos advindos da limitada infra-estrutura de transportes presentes no espaço geográfico regional, a Transpetro, a BR Distribuidora, -subsidiárias da Petrobrás - e a Secretaria de Transportes do Estado de São Paulo, estudam a colocação em funcionamento do modal hidroviário através da modernização da hidrovia Tietê-Paraná. 


\section{Mapa 8: Transcurso da Hidrovia Tietê-Paraná}

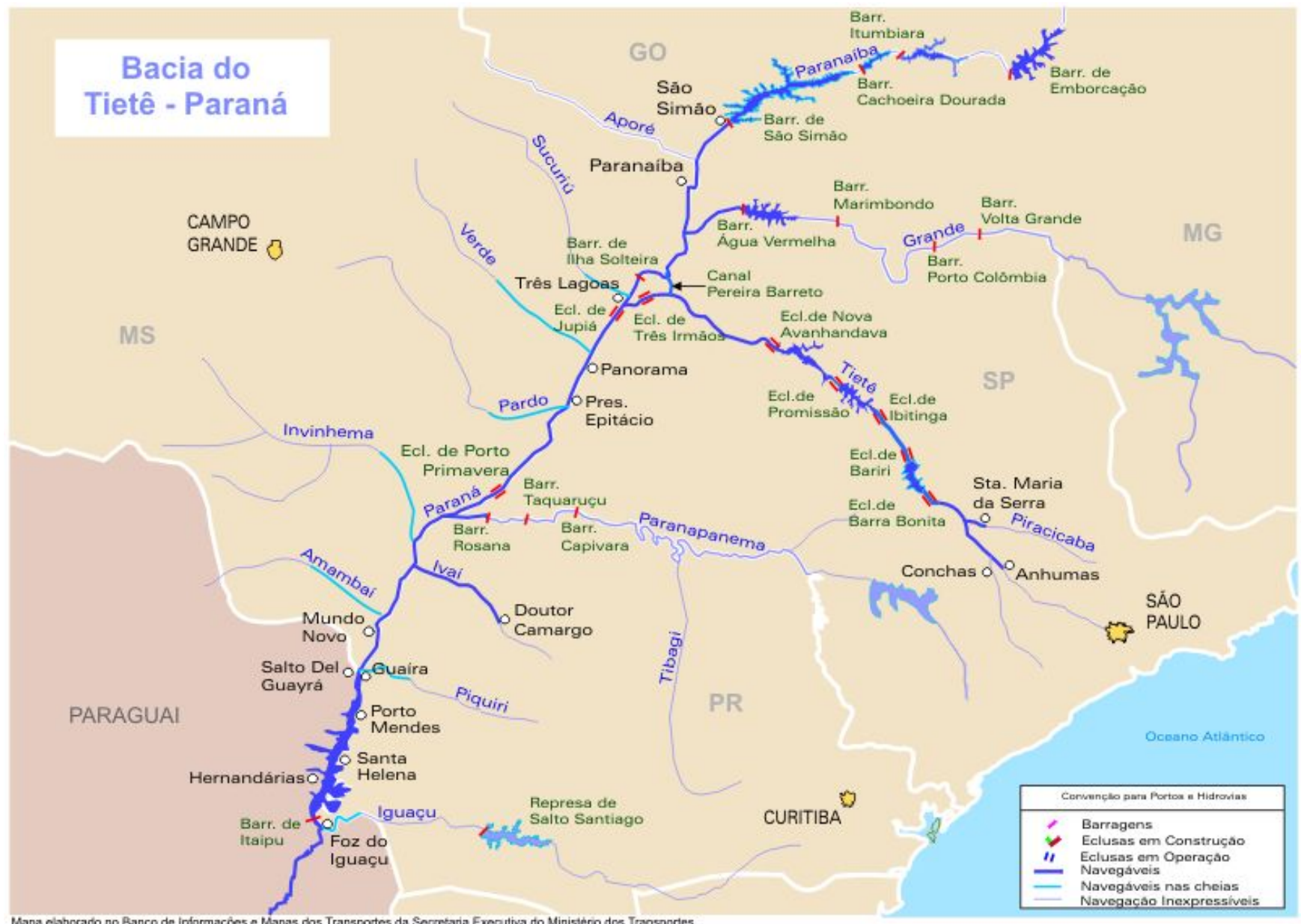

Fonte: http://209.15.138.224/brazil_maps/m_agua_Tiete_Paranax.htm; Acesso Disponível em 03/09/2008. 
A partir de uma previsão orçamentária de aproximadamente $\mathrm{R} \$$ 300 milhões, pretende-se instalar até 2011 novos terminais portuários e ligações fluidas - com o aumento do potencial dos calados dos rios - com outros modais em municípios de Goiás, Minas Gerais, Mato Grosso do Sul, Paraná e São Paulo. No transcurso do rio Tietê, no sentido interior-capital, a idéia é avolumar o transporte hidroviário de soja, farelo, milho e prioritariamente cana-de-açúcar e derivados ${ }^{89}$. No sentido inverso, capitalinterior, almejam-se superar os gargalos atuais - devido à volta de muitas embarcações vazias - realizando carregamentos principalmente de combustíveis e insumos agrícolas.

${ }^{89}$ Fazendo uso da flexibilização para o escoamento de açúcar para exportação, em julho de 2008, “ $a$ Usina Pioneiros, localizada em Sud Menucci, no interior paulista, iniciou o escoamento de parte da sua produção de açúcar para o Porto de Santos, pela hidrovia Tietê-Paraná. Ontem (31), a unidade realizou a terceira expedição do mês, com seis mil toneladas de açúcar VHP. A carga, cujo volume representa a capacidade máxima da barcaça, por conta do limite do calado do rio, é transportada para o armazém da empresa, em Anhembi, SP, distante cerca de 400 quilômetros da usina. O trajeto é percorrido em pouco mais de dois dias, mas pode chegar a quatro, por conta de aspectos climáticos e tráfego de embarcações nas eclusas. De acordo com o coordenador da logística de expedição da usina, Marcelo Payá, a opção pela hidrovia significa redução de custos. Em julho, a empresa economizou cerca de $R \$ 10$ por tonelada de carga, referentes ao preço do frete rodoviário cobrado neste período - o valor do frete é variável. O uso da hidrovia substitui cerca de 170 carretas por embarque” (http://www.canaweb.com.br/conteudo/noticia.asp?area=Producao\&secao=Exclusivas\&ID_Materia=316 77, acesso em 04/08/2008). 


\section{Foto 54: Barcaça Navegando na Hidrovia Tietê-Paraná}

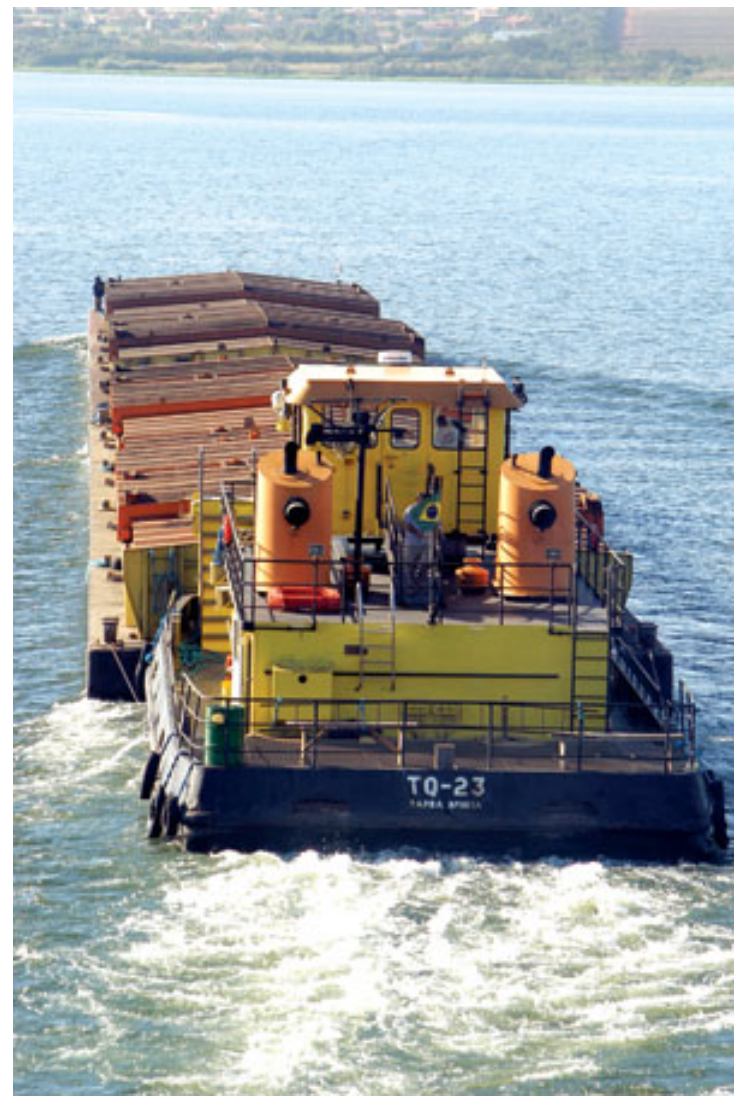

Fonte: Folha da Região, 11/10/2007 (http://www.folhadaregiao.com.br/noticia?77679; Acesso Disponível em 03/09/2008).

Seguindo os mesmos objetivos, a partir da verificação das estimativas de crescimento do plantio de cana e da exportação de açúcar e álcool, o alongamento do sistema de engenharia para o transporte dessas mercadorias $^{90}$ é vislumbrado pela anexação ao espaço geográfico do CentroSul - principal região produtora de cana-de-açúcar do país - de alcoodutos interligados aos modais rodoviário, ferroviário e hidroviário. Divulgado para entrar em funcionamento em 2012 (mesmo não traçando em terras araçatubenses), o alcooduto projetado pela Transpetro servirá para o escoamento do álcool produzido no Oeste Paulista, prioritariamente o da Região Administrativa de Araçatuba (que é cortada ao meio pelo rio Tietê).

\footnotetext{
${ }^{90}$ Segundo relatos da União da Indústria Canavieira de São Paulo (UNICA), os problemas de logística dos transportes ocasionam a perda de metade das vantagens competitivas do etanol brasileiro.
} 
Com braços localizados em Guararema (SP) e Santa Maria da Serra (SP) ou Conchas (SP), na região do Alto Tietê (Leste Paulista), o alcooduto sugará o etanol vindo da hidrovia na direção interior-capital e o locomoverá para as refinarias de Duque de Caxias (SP) ou Paulínia (SP), para posteriormente alcançar o mundo, respectivamente via os portos de Ilha D’Água (RJ) e São Sebastião (SP).

Toda essa dinamização pretendente para os fluxos do setor canavieiro, com o planejamento da instalação de novos objetos geradores de fluidez, tem sido condicionada mediante o lobby dos usineiros atuantes na região. Organizados em torno da UDOP, sob o vislumbre das potencialidades do espaço geográfico regional na expansão do circuito espacial da cana-de-açúcar, desde 2003 realizam em Araçatuba a Feira de Negócios da Agroindústria Canavieira (Feicana) ${ }^{91}$. Com a presença de políticos representantes do setor agropecuário (bancada ruralista), empresas expositoras, bancos, usineiros, universidades, institutos de pesquisa, departamentos governamentais e visitantes em geral, este evento - enquanto lócus de debates, palestras, seminários, cursos e discussões sobre a cultura da cana-de-açúcar -, tem batido recordes de negócios ano após ano ${ }^{92}$. Com isso, descentraliza-se a gestão técnica do espaço geográfico de atuação do setor no Centro-Sul, redirecionando as localizações principalmente das empresas prestadoras de serviços. Já em 2003, durante a $1^{a}$ Feicana (Feira de Negócios de Energia), o "setor sucroalcooleiro trouxe oito empresas para Araçatuba (...). O valor do investimento passa de R\$ 2 milhões, com a geração de 82 empregos diretos. As empresas atuam nas áreas de energia,

\footnotetext{
${ }^{91}$ Em 2006, com a intenção de sedimentar o etanol como alternativa energética ambientalmente correta, a Feicana passa a se denominar Feicana/FeiBio (Feira de Negócios do Setor de Energia). O objetivo é principalmente direcionar as discussões e estratégias para convencer o mercado da limpeza do processo produtivo do açúcar e álcool, do potencial energético da palha da cana e dos condicionantes que possibilitam a diminuição do uso dos combustíveis fósseis.

${ }^{92}$ Em 2003, a feira fechou negócios em torno de R\$ 250 milhões, com 60 expositores e 11 mil visitantes. Em 2004 movimentou R \$ 350 milhões, com 120 expositores e 15 mil visitantes. Em 2005 se avolumou fechando R\$ 500 milhões em negócios, com 140 expositores e mais de 20 mil visitantes. Em 2006, atingiu R\$ 750 milhões, com 250 expositores e 25 visitantes. No ano de 2007 movimentou R\$ 1 bilhão, com 280 expositores e 28 mil visitantes. Em 2008, novamente bateu recorde de negócios, ultrapassando pouco mais de R\$ 1,5 bilhão, com 300 expositores e 25 mil visitantes (www.udop.com.br; Acesso Disponível em 04/08/2008).
} 
automação industrial, manutenção de equipamentos e venda de máquinas e implementos agrícolas.” (Folha da Região, 09/03/2004) ${ }^{93}$.

\section{Foto 55: Feicana 2006}

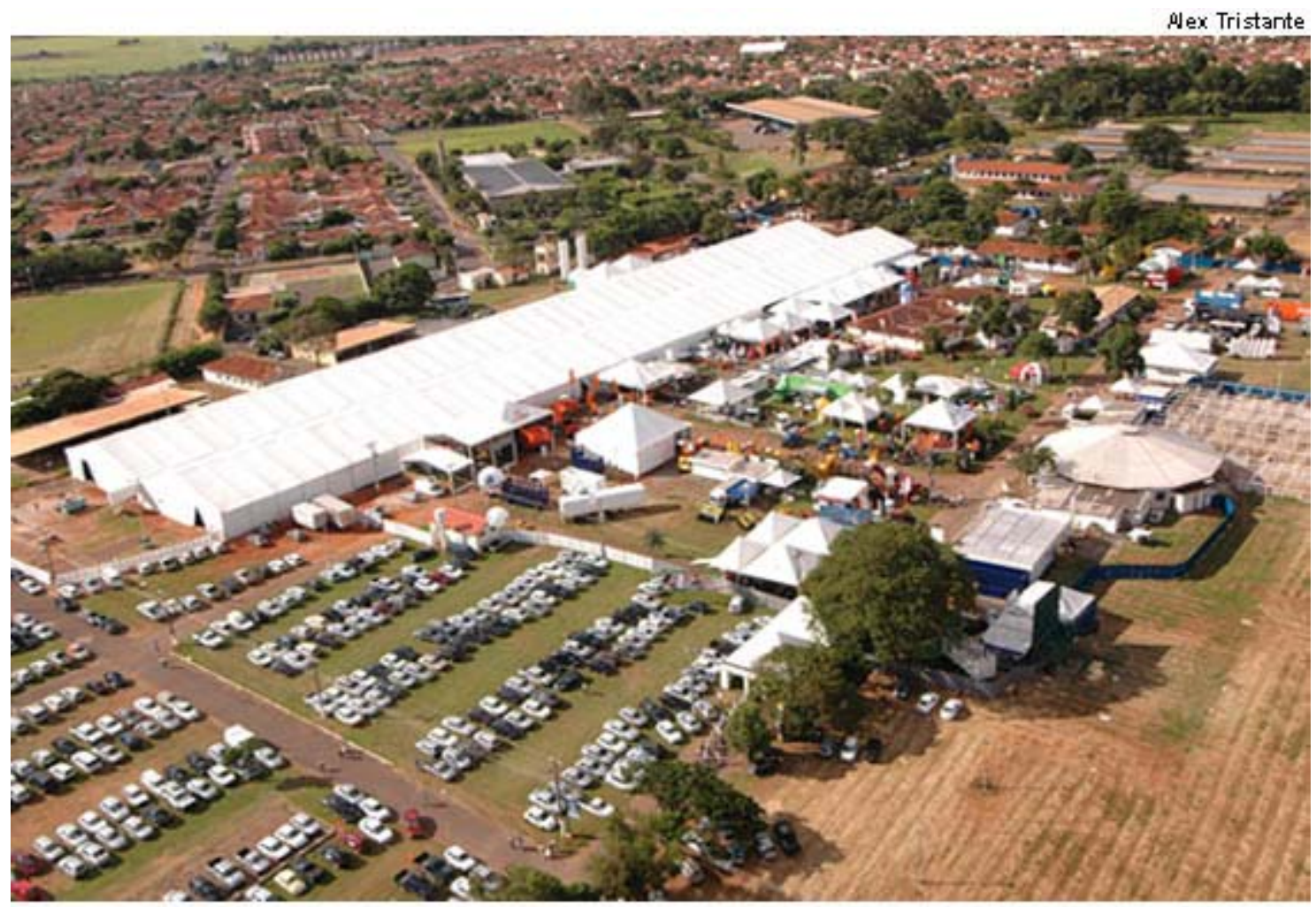

Wsta aérea da Feicana/Fei Bio 2006 - público recorde e negócios de mais de R\$720 milhöes

Fonte: Agência Udop de Notícias, 17/03/2006.

\footnotetext{
${ }^{93}$ Coopercitrus, de Bebedouro (SP); Smar e Sertron, de Sertãozinho (SP); Elo Indústria, Serviços e Comércio de Equipamentos, de Osasco (SP); Tecnocal Tecnologia em Vapor, de Ribeirão Preto (SP); Siner, de São Paulo (SP) e as multinacionais japonesa e norte-americana Yokogawa e Dupont são as oito empresas retratadas na matéria jornalística que instalaram atividades diretas de prestação de serviços ao setor sucroalcooleiro na região de Araçatuba nesse início dos anos 2000.
} 
Com a amplitude do crescimento do setor no oeste paulista, as empresas à montante, diferente da década de 1980 (quando prestavam serviços a partir de suas instalações externas à região de Araçatuba), passam a encontrar vantagens - devido ao aumento da escala dos negócios, que possibilitam diminuir os custos do processo - na instalação direta de suas atividades internamente à região ${ }^{94}$. Atores regionais - também vislumbrando as oportunidades com a expansão desse mercado - começam a se especializar nos serviços requisitados do setor e avolumam suas áreas de atuação ${ }^{95}$.

Esses eventos ligados ao circuito espacial de produção da cana-deaçúcar, através da injeção de capitais diretos no setor, têm condicionado o crescimento indireto de outras atividades econômicas. Liderando a geração de novos empregos na região - onde muitos são preenchidos por migrantes , as indústrias de açúcar e álcool aumentam a demanda por mercadorias e serviços. Para equilibrar o mercado, ofertando segundo as novas necessidades quantificadas, nos últimos anos a abertura de empresas comerciais e industriais tem acompanhado a dinâmica vigorosa da atividade canavieira ${ }^{96}$. Assim, segundo a Fundação Seade, para o ano de 2005, a Região Administrativa de Araçatuba é a que mais cresce percentualmente em investimentos no estado de São Paulo ${ }^{97}$.

\footnotetext{
${ }^{94}$ Todos os anos, durante a Feicana/FeiBio, empresas ligadas ao setor sucroalcooleiro anunciam suas novas instalações na região.

${ }^{95}$ Por exemplo, a empresa Saltec Soluções Industriais, inaugurada em 2005, com sede em Araçatuba, a cada Feicana tem aumentado seu raio de atividade na prestação de serviços ao setor. Algumas outras, também araçatubenses, no reflexo do bom momento econômico, com o retorno lucrativo adquirido estão realizando investimentos diretos em outros centros regionais, instalando lojas e fábricas.

${ }^{96}$ Para a Junta Comercial do Estado de São Paulo (Jucesp), baseado em dados dos primeiros seis meses de 2007, de cada duas empresas fechadas em Araçatuba, nove abrem as portas.

${ }^{97}$ Com investimentos da ordem de U\$ 725,95 milhões, em 2005 essa quantia representou uma porcentagem $185 \%$ maior do que a do ano anterior.
} 
O município de Araçatuba, enquanto pólo regional é aquele que mais tem se beneficiado com esse processo: atingindo maior capacidade de consumo ano após ano ${ }^{98}$, vê pipocar em sua delimitação geográfica novos objetos e ações caracterizadores do crescimento econômico vivido ${ }^{99}$. Indústrias dos setores alimentício, cosmético, têxtil, informática e outros, aproveitando esse crescimento regional, estão instalando suas atividades em Araçatuba. Financiamento e locação de imóveis em alta têm valorizado o solo urbano, e a construção civil, registrando aumento nas contratações de mão-de-obra apresenta inflacionamento em seu processo produtivo. A rede de hotéis, deficitária no atendimento aos maiores eventos regionais - como a Feicana/FeiBio - também passa por reestruturação, melhorando seus serviços e aumentando sua capacidade instalada ${ }^{100}$. Novas concessionárias de automóveis e motocicletas incrementam os fluxos nas ruas e avenidas da cidade $^{101}$, e novos bares, restaurantes, supermercados, casas noturnas e lojas intensificam o surgimento de novas centralidades comerciais no município. Pelos ares, o aumento do fluxo de capitais novamente é detectado: a partir de dados do Departamento Aeroviário do Estado de São Paulo (Daesp), em 2007, após a instalação de mais duas companhias aéreas como opção a diferentes trajetos pelo território nacional, o aeroporto de Araçatuba atingiu a terceira colocação entre os mais movimentados do interior paulista ${ }^{102}$.

\footnotetext{
${ }^{98}$ Segundo estudo da empresa especializada em pesquisa de mercado Target Marketing, que anualmente apresenta o ranking nacional do IPC Target (Îndice de Potencial de Consumo) das municipalidades brasileiras.

${ }^{99}$ Indicativo desse maior potencial de consumo regional, a Companhia Paulista de Força e Luz (CPFL) registrou nos primeiros nove meses de 2007, em Araçatuba, no comparado com 2006, um reajuste de quase 12 \% no consumo de energia pelo setor industrial (Folha da Região, 27/12/2007, pág. A4).

${ }^{100}$ Em fevereiro de 2008, na mesma semana da $8^{\text {a }}$ Feicana/FeiBio, foi inaugurado em Araçatuba um hotel da rede européia Íbis. Com 108 apartamentos, este novo estabelecimento ajudou a qualificar a oferta de estadia aos visitantes da feira.

${ }^{101}$ Esse aumento na frota regional tem atraído mais serviços de financiamento e seguro de veículos. Como exemplo, o Itaucred, do Banco Itaú, inaugurou suas instalações em Araçatuba em abril de 2008.

102 Devido ao aumento do movimento de vôos, houve crescimento de aproximadamente $50 \%$ no faturamento dos taxistas e do restaurante do aeroporto local (Folha da Região, 12/05/2007, pág. A4).
} 
Para finalizar a apresentação de algumas das implicações sócioespaciais da expansão da lavoura canavieira nos arredores do município de Araçatuba, vale lembrar que todo esse crescimento requisita, além dos trabalhadores pouco qualificados para o corte da cana, pessoas com boa formação técnica para ocupar diferentes cargos estratégicos nos departamentos das novas empresas instaladas na região. Para absorver a demanda dessa mão-de-obra qualificada que o setor sucroalcooleiro e outros a reboque requerem nesse momento de crescimento regional, novos cursos técnicos, de graduação, pós-graduação e capacitação de mão-de-obra surgiram nos últimos anos (principalmente de 2005 em diante) principalmente no município de Araçatuba, com o intuito de evitar gargalos elevadores de custos com folha de pagamento para as empresas ${ }^{103}$. Fatec (Faculdade de Tecnologia) e Etec (Escola Técnica Estadual), oferecendo cursos - superiores e técnicos, respectivamente - ligados à produção de açúcar e álcool e geração de bioenergia, são os investimentos públicos diretos no município-sede da Região Administrativa realizados pelo governo do estado de São Paulo na criação de mão-de-obra qualificada. Cursos de capacitação, especialização e pós-graduação são iniciativas prioritariamente do setor privado, que com capitais das universidades e faculdades já existentes, de Sindicatos e Associações Patronais ${ }^{104}$, financiamento bancário (BNDES, por exemplo) e empresas ligadas ao setor canavieiro direcionam em salas de aula e laboratórios a formação de trabalhadores para as funções com escassez de mão-de-obra na região ${ }^{105}$.

\footnotetext{
103 É natural a elevação dos custos com mão-de-obra quando esta é escassa no lugar de execução dos empreendimentos. Na necessidade de buscá-la em outros pontos do espaço geográfico, os custos também são maiores do que encontrá-la em loco, principalmente quando sua requisição é em grande quantidade.

${ }^{104}$ O Senai, o Sesi e a Ciesp são as principais entidades das indústrias paulistas que têm realizado enormes empenhos em assistir as empresas regionais com formação de mão-de-obra qualificada.

${ }^{105}$ A Valtra e a New Holland, construtoras de máquinas e implementos para o setor agrícola, em parceria com produtores da região realizam cursos de capacitação de manuseio de suas inovações mais recentes.
} 


\section{4) Algumas Mudanças na Pecuária Bovina e Outras Culturas}

Agrícolas na Região de Araçatuba no Início dos Anos 2000

A expansão da cultura da cana-de-açúcar no estado de São Paulo, e especificamente no oeste paulista e na região de Araçatuba, no início do século XXI, ocasionou mudanças na atividade da pecuária bovina de corte. Com a atividade canavieira proporcionando maiores rendimentos no uso das terras regionais do que a pecuária tradicionalmente extensiva, continua-se o deslocamento pelos pecuaristas regionais da atividade de engorda nesse tipo de manejo (extensivo) para áreas de terras baratas, principalmente as recémdesmatadas no Centro-Oeste e Norte do país ${ }^{106}$.

106 Já era tradicional a realização predominante da cria (bezerro) e recria (garrote) no Centro-Oeste e Norte do país desde a hegemonização da pecuária na região de Araçatuba. A engorda extensiva, fase final antes do abate, acontecia em terras paulistas próximas às plantas frigoríficas. Hoje, deslocada cada vez mais - devido a expansão canavieira em sua área tradicional (o oeste paulista) - para as novas pastagens surgidas após a derrubada da floresta, coloca na ordem do dia o problema da sustentabilidade indireta ocasionada pelo etanol da cana-de-açúcar. Ou seja, a expulsão da pecuária feita pela cana-de-açúcar para áreas desmatadas na Amazônia brasileira pode gerar barreiras não-alfandegárias à exportação de carne, açúcar e álcool segundo critérios de defesa do meio-ambiente, principalmente na atualidade, quando está em voga a discussão sobre o aquecimento global. 
Tabela 30 - Evolução da Área de Pastagens (em hectares) e Rebanho Bovino por Região Administrativa do Estado de São Paulo, 2000 -2007.

\begin{tabular}{|c|c|c|l|c|}
\hline $\begin{array}{c}\text { Divisão } \\
\text { Regional }\end{array}$ & Área & Rebanho & Área & Rebanho \\
2000 & 2000 & 2007 \\
\hline P. Prudente & 1.829 .424 & 2.277 .600 & 1.609 .150 & 2.323 .291 \\
\hline S J Rio Preto & 1.448 .783 & 2.075 .045 & 1.162 .139 & 1.833 .656 \\
\hline Sorocaba & 1.386 .462 & 1.507 .906 & 1.521 .586 & 1.626 .943 \\
\hline Araçatuba & $\mathbf{1 . 1 9 8 . 2 5 4}$ & $\mathbf{1 . 8 5 1 . 9 1 6}$ & $\mathbf{1 . 0 0 4 . 9 2 1}$ & $\mathbf{1 . 5 0 3 . 6 9 1}$ \\
\hline Marília & 994.002 & 1.299 .947 & 870.302 & 1.211 .322 \\
\hline Bauru & 823.629 & 1.091 .407 & 685.187 & 1.062 .913 \\
\hline Campinas & 787.015 & 941.017 & 736.047 & 1.003 .656 \\
\hline S. J. Campos & 661.495 & 517.227 & 685.195 & 532.604 \\
\hline Franca & 293.570 & 380.609 & 242.650 & 303.707 \\
\hline Central ${ }^{107}$ & 243.024 & 344.011 & 199.230 & 265.571 \\
\hline Barretos & 184.749 & 289.750 & 122.795 & 202.151 \\
\hline Rib. Preto & 162.123 & 201.049 & 155.872 & 185.669 \\
\hline Registro & 124.885 & 84.860 & 149.810 & 99.552 \\
\hline São Paulo & 18.969 & 36.907 & 29.442 & 32.285 \\
\hline B. Santista & 2.410 & 2.705 & 1.329 & 2.629 \\
\hline Estado & 10.168 .794 & 12.901 .962 & 9.185 .648 & 12.198 .662 \\
\hline
\end{tabular}

Fonte: Banco de Dados do Instituto de Economia Agrícola (IEA).

${ }^{107}$ A Região Administrativa Central compreende as Regiões de Governo de Araraquara e São Carlos. 
Mapa 9: Distribuição de Bovinos no Território Brasileiro (1995-1996)

Cartograma 5 - Pecuária - Bovinos em 31.12.1995

Densidade de bovinos por $\mathrm{km}^{2}$ de área territorial - 1995-1996

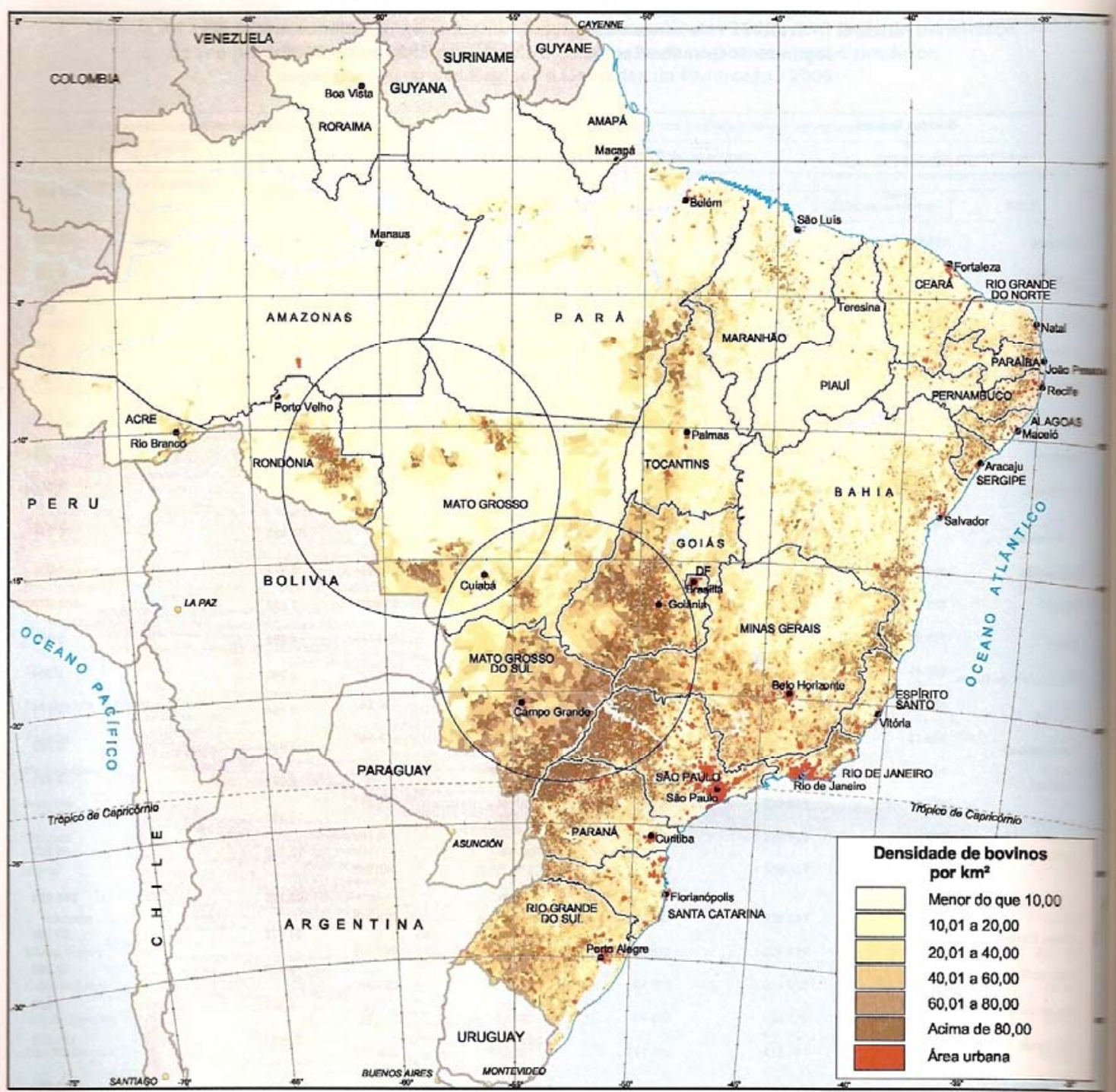

Fonte: IBGE, Censo Agropecuário 1995-1996.

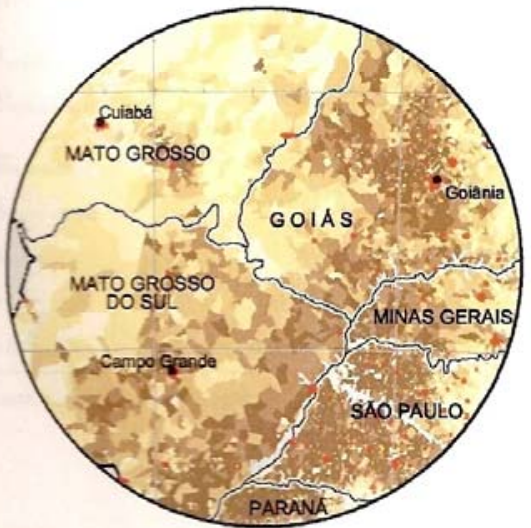

118 Censo Agropecuário 2006 Resultados preliminares

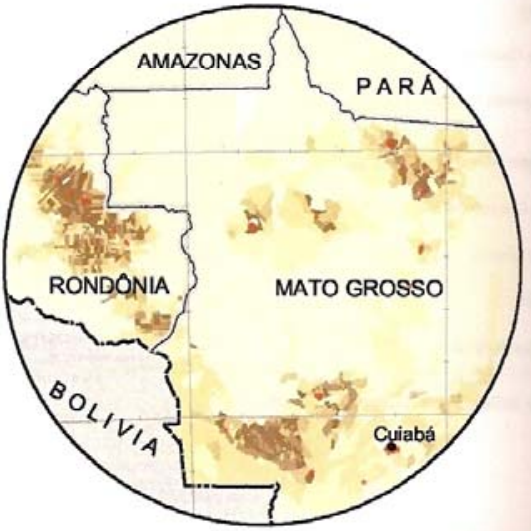

CENSם5

Fonte: Censo Agropecuário 2006, Resultados Preliminares, IBGE, Rio de Janeiro, 2007. 
Mapa 10: Distribuição de Bovinos no Território Brasileiro (2006)

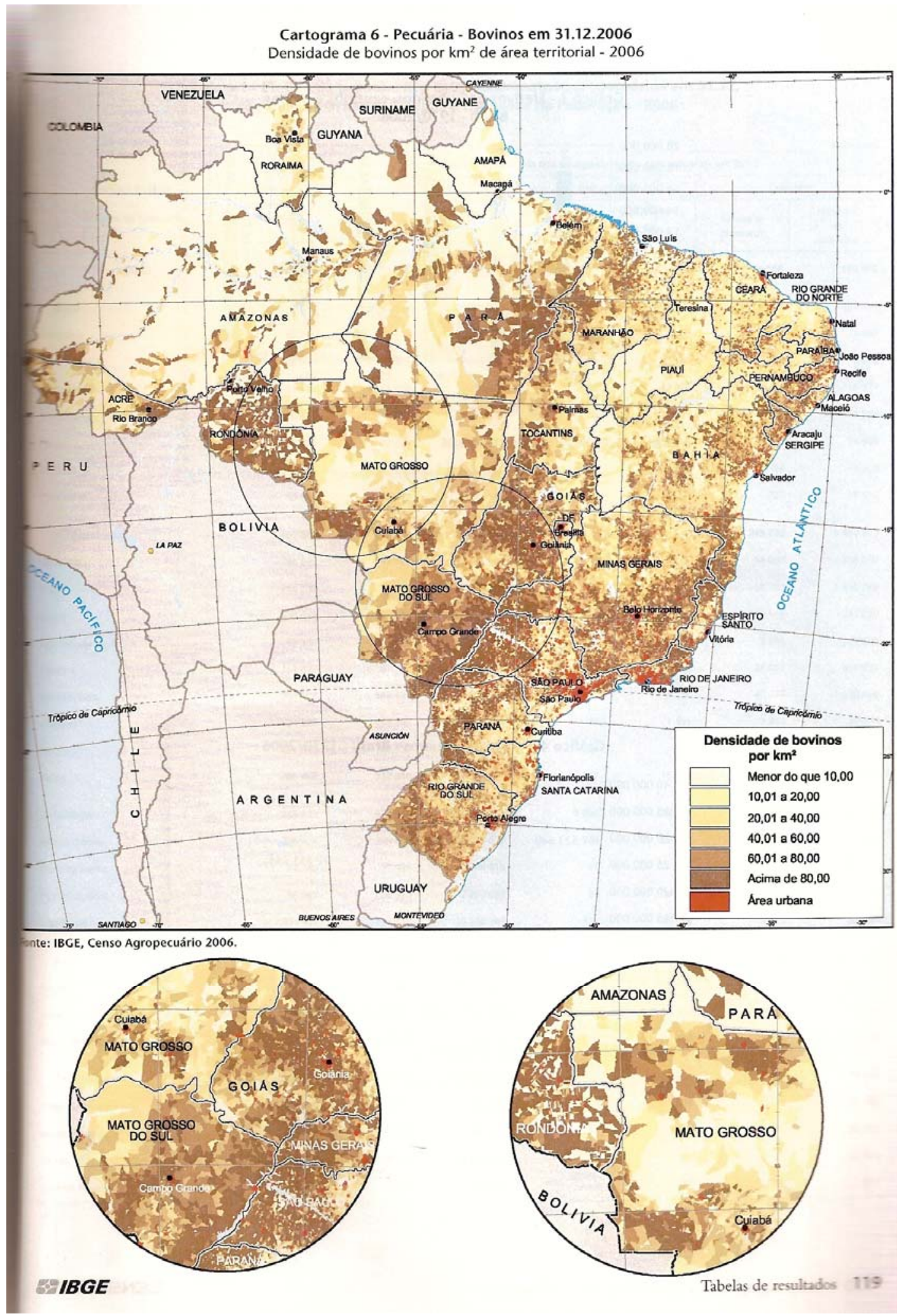

Fonte: Censo Agropecuário 2006, Resultados Preliminares, IBGE, Rio de Janeiro, 2007. 
Torna-se atrativa a engorda na região araçatubense, no oeste paulista - competindo com a lucratividade oferecida em meados da primeira década dos anos 2000 da cultura da cana-de-açúcar - quando intensificada em confinamentos e semi-confinamentos (Rocha Filho, 2006) ${ }^{108}$. Em espaçamentos menores, essa modernização é conquistada através dos melhoramentos nas pastagens e nas linhagens genéticas dos plantéis de bovinos $^{109}$, possibilitando um aumento da produtividade, com os animais atingindo o peso ideal de abate em um período menor. Seguindo esses indicadores, estima-se que no ano de 2007 quase 200.000 bovinos tenham passado seus últimos 120 dias de engorda em manejos intensificados localizados na região, onde recebem uma alimentação diferenciada à base de sorgo, milho, polpa cítrica e bagaço de cana suplementados por uma mistura de minerais específicos para a engorda de bovinos ${ }^{110}$.

\footnotetext{
${ }^{108}$ Na recria e engorda extensiva se obtêm rendimentos também comparativos aos da cana-de-açúcar no oeste paulista uma exceção de pecuaristas que possuindo uma boiada numerosa, mesmo alcançando uma margem de lucro pequena por cabeça de gado, na soma final adquirem vencimentos volumosos em suas contabilidades (Essa informação foi dada em entrevista no dia 11 de novembro de 2007 pelo pecuarista Jaime Rosseto, de Araçatuba). A cria, por requisitar de maiores áreas do que as outras fases do processo produtivo, apresenta-se em menores proporções nas terras da região, sendo realizada por poucos atores do setor que optam pela integração cria-recria e cria-recria-engorda em suas propriedades. Porém, são em áreas extensas e baratas externas ao espaço geográfico paulista que ocorrem essa primeira fase do circuito produtivo pecuário: a vaca no período de amamentação e o bezerro em fase de crescimento comem bem mais e necessitam de um espaçamento maior do que os bovinos nos momentos posteriores do manejo. Sendo assim muito custosa, direciona-se essa etapa para grandes áreas de terras mais baratas.

109 A base dessas linhagens melhoradas, segundo especialistas entrevistados na região, deriva das pesquisas realizadas pela tradicional empresa VR, já comentada em momento anterior desse trabalho.

110 Com o intuito de apontar uma oferta menor para obtenção de melhores preços, o sindicato dos pecuaristas da região (SIRAN) divulgou para o ano de 2007 a passagem de 50 mil cabeças de gado por manejo confinado na região. Porém, somente no maior confinamento, localizado no município de Andradina, que abastece prioritariamente o frigorífico do grupo JBS Friboi, passaram, segundo vários informantes do setor - veterinários, pecuaristas, agrônomos - quase 100 mil bovinos.
} 
Fotos 56, 57, 58, 59 e 60: Confinamento para Bovinos de Corte na Região de Araçatuba
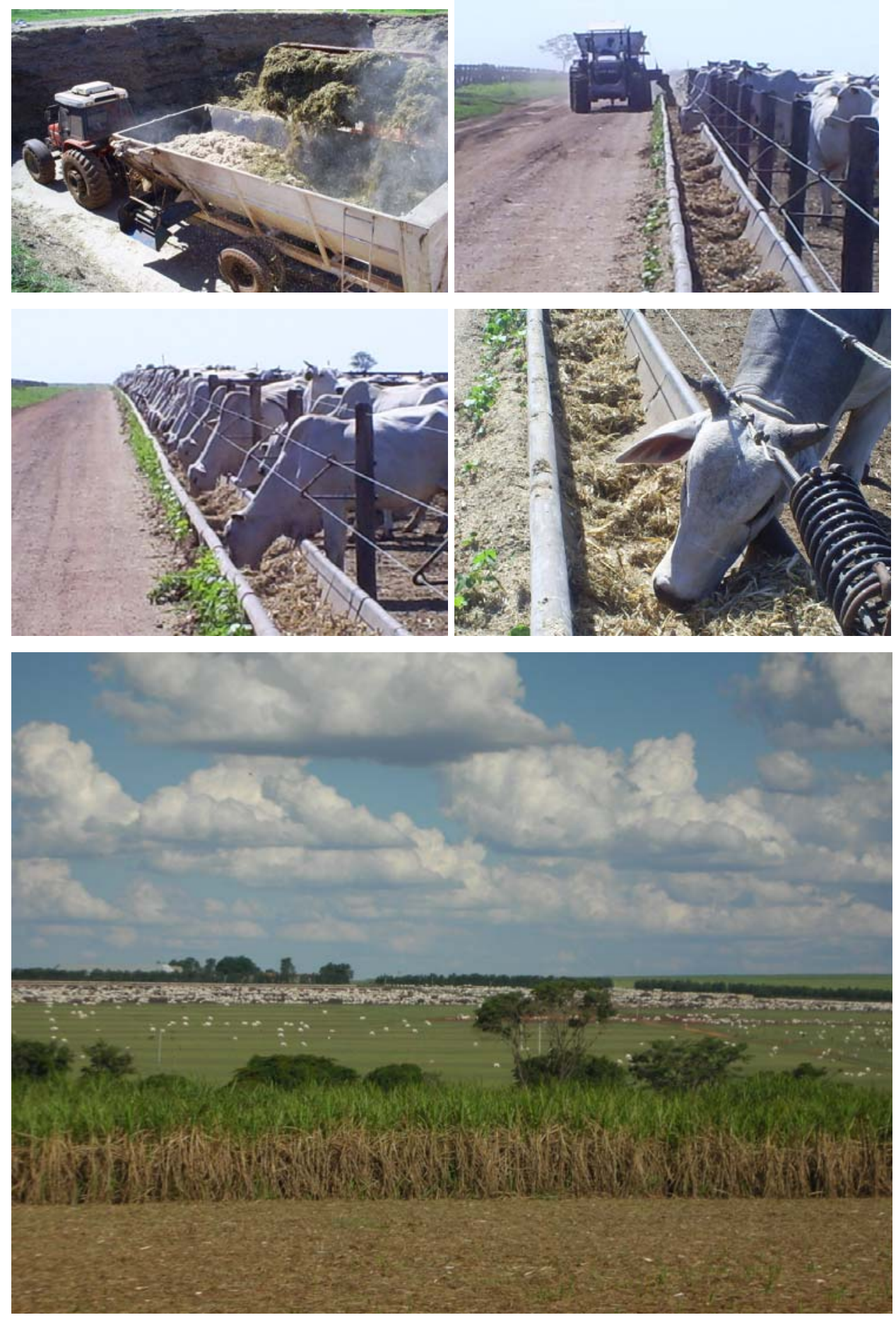

Fonte: Bini, 2008; UDOP, 2008.

Com essas transformações - deslocamento gradual da atividade de engorda extensiva para outras localidades do país e intensificação dessa fase 
do processo produtivo em terras araçatubenses - diminuiu nos últimos anos

a área de pastagens e o número de bovinos no espaço geográfico regional.

Tabela 31

Região de Araçatuba

Área de Ocupação das Pastagens, Número do Rebanho Bovino e Relação

Bovinos/Ha (2000 - 2007)

\begin{tabular}{|c|c|c|c|}
\hline Ano & $\begin{array}{c}\text { Área de } \\
\text { Pastagens } \\
(\mathrm{Ha})\end{array}$ & $\begin{array}{c}\text { Número do } \\
\text { Rebanho } \\
\text { Bovino }^{111}\end{array}$ & $\begin{array}{c}\text { Relação } \\
\text { Bovino/Ha }\end{array}$ \\
\hline 2000 & 1.198 .254 & 1.851 .916 & 1,54 \\
\hline 2007 & 1.004 .921 & 1.503 .691 & 1,49 \\
\hline Fonte: Instituto & de $\quad$ Economia & Agrícola & (IEA), Banco \\
\hline
\end{tabular}

(http://www.iea.sp.gov.br/out/banco/menu.php): Acesso Disponível em 14/08/2008.

Assim, mesmo mantendo a mesma relação bovinos/ha entre os anos de 2000 e 2007, o que se observa, a partir de informações relatadas por representantes dos setores pecuário e canavieiro (como por exemplo, veterinários e engenheiros agrônomos das Casas da Agricultura dos municípios da região) e visitas a propriedades na região, é que parte das áreas computadas como de pastagens existentes estão praticamente sem rebanho ${ }^{112}$, em processo de negociação ou já negociadas para a instalação de novos canaviais que serão requisitados pelas aproximadamente 30 novas

\footnotetext{
${ }^{111}$ Nessas duas datas, aproximadamente 5\% do rebanho são de raças específicas para a produção leiteira e raças mistas, com serventias tanto pro corte quanto pra ordenha corresponderam a $30 \%$ do rebanho regional. Com a inauguração da segunda unidade da multinacional Nestlé no segundo semestre de 2007, a empresa, o Sebrae, a administração pública e os produtores rurais não medem esforços para o aumento do rebanho leiteiro e sua produtividade na região. O programa Balde Cheio, direcionado para capacitar os produtores no uso de manejos e técnicas mais intensivas é um exemplo dessa tentativa de aumentar a oferta de leite requisitada pela multinacional.

112 Ou seja, sem boiadas ou com boiadas em transferência para outras regiões. Um exemplo desse processo, a Agropecuária Jacarezinho - do grupo Grendene -, localizada no município de Valparaíso, adquiriu uma área de 47 mil hectares no oeste baiano (onde o preço da terra é 30 vezes menor do que as possuídas na região de Araçatuba), para onde irá transferir ao longo dos próximos cinco anos o seu plantel de fêmeas (matrizes) e animais para engorda sediados no espaço geográfico regional em estudo. Essa transferência da boiada abrirá espaço para ampliar a produção de cana-de-açúcar e o funcionamento da unidade produtiva de açúcar e álcool construída pelo grupo, a usina Da Mata.
} 
usinas de açúcar e álcool que estão sendo construídas no oeste paulista e serão inauguradas, segundo a UDOP, até 2010. Acreditamos ser somente a partir dessa mudança na composição agrícola nas terras da região é que a intensificação na relação de bovinos por área será identificada.

Dessa forma, a atuação dos pecuaristas regionais se encaminha ao reforço do binômio cana-boi iniciado na década de 1980: arrenda-se a maioria da propriedade ao cultivo da cultura canavieira ${ }^{113}$ e intensifica a parte restante da atividade pecuária em confinamentos e semiconfinamentos $^{114}$. Fruto da herança histórica enquanto “capital do boi gordo” adquirida em meados do século XX e pelo domínio que ainda exercem sobre uma fatia da atividade pecuária brasileira, mesmo direcionando cada vez mais suas ações no setor para o Centro-Oeste e Norte do país, são de seus escritórios localizados principalmente na região central de Araçatuba que os pecuaristas regionais dão suas cartadas no direcionamento do preço dos animais no mercado nacional de bovinos.

No que se refere ainda à intensificação, outra mudança retratada no circuito espacial de produção da pecuária bovina de corte na região é a tentativa de uma maior integração entre os produtores e as plantas frigoríficas modernas. Através de contratos entre as partes, objetiva-se garantir a estabilidade do fornecimento de uma matéria-prima de boa qualidade, onde critérios como precocidade (adiantamento do tempo de vida para o abate dos animais de linhagens genéticas melhoradas) e rastreabilidade (histórico de vida dos animais, no percurso do nascimento ao abatedouro, com o uso de técnicas informatizadas) normatizam uma verticalização que se estende até às exigências fito-sanitárias negociadas e impostas pelos importadores de carne bovina.

\footnotetext{
113 Em entrevistas feitas na região, constatamos que somente uma pequena fatia da cana plantada é realizada pelos próprios proprietários rurais. Evitando o risco de perdas, preferem-se os rendimentos garantidos com o arrendamento. Há casos daqueles proprietários rurais que também arrendam a totalidade de suas terras para cana.

114 O presidente do Siran, o pecuarista Alfredo Neves Filho, foi um daqueles que reestruturou seus negócios reduzindo as áreas de pecuária extensiva direcionando-as para a cana e intensificando a engorda em confinamentos (Revista Exame, 18/06/2008, pág. 123).
} 


\section{Foto 61: Veterinário de Araçatuba Realizando Rastreabilidade de \\ Bezerros de Elite (Futuros Reprodutores) em Banco de Dados \\ Informatizado Cadastrado na Associação Brasileira de Criadores de \\ Zebu (ABCZ)}

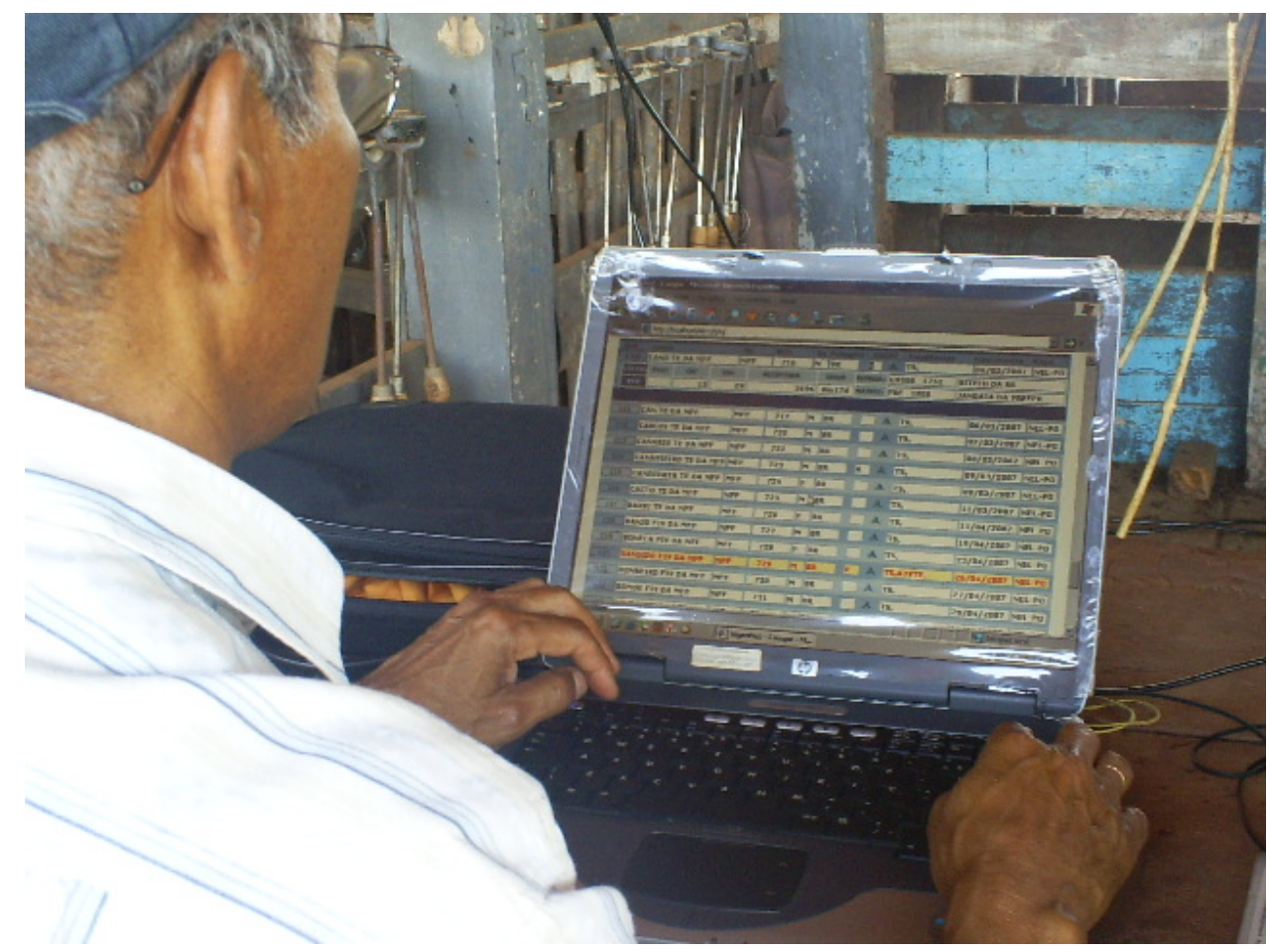

Fonte: Bini, 2008.

Na região de Araçatuba, processos modernos dessa natureza acontecem principalmente para o abastecimento da unidade produtiva do grupo JBS Friboi, localizada no município de Andradina e também para o frigorífico do grupo Bertin, localizado no município de Lins ${ }^{115}$. Essas duas indústrias são as maiores exportadoras de carne e produtos derivados da pecuária bovina de corte acontecida nas redondezas de Araçatuba.

\footnotetext{
${ }^{115}$ O município de Lins é sede de uma Região de Governo integrante da Região Administrativa de Bauru. Estando na contigüidade à Região Administrativa de Araçatuba, esses fragmentos do espaço geográfico paulista mantêm relações intensas nos circuitos espaciais de produção da cana de açúcar e da pecuária bovina de corte. Promissão, por exemplo, o segundo maior município da Região de Governo de Lins, localizado na divisa entre as RAs de Araçatuba e Bauru, através das usinas de açúcar e álcool Equipav e Córrego Azul e do frigorífico Marfrig, atrai parte da matéria-prima beneficiada nessas agroindústrias, da produção agropecuária araçatubense.
} 
Contudo, é importante salientar que essa modernização é apenas um apontamento minúsculo da cadeia produtiva da carne na região. A maioria das relações entre os elos do setor se discorre dentro de conexões complexas e frágeis, com as negociações de compra e venda acontecendo alguns dias antes do abate, sendo o critério determinante o preço. Dessa forma, boiadas localizadas nas proximidades de um frigorífico são vendidas para serem abatidas em outro a dezenas ou centenas de quilômetros! ${ }^{116}$. São distorções que, com a diminuição da oferta de animais na hinterlândia de Araçatuba e no estado de São Paulo como um todo ${ }^{117}$, diminuiu cada vez mais as margens de lucro de várias plantas frigoríficas em terras paulistas, levando muitas à desativação ${ }^{118}$ e direcionando o setor de abate à concentração nas mãos de poucos grupos que têm reestruturado suas atuações com uma maior integração entre todos os elos da cadeia produtiva em novas plantas no Centro-Oeste e Norte do país, para onde estão sendo deslocadas as pastagens e boiadas no território brasileiro. Restam àqueles que resistem na execução de ações tradicionais e arcaicas uma pequena fatia do mercado de abate, que realizado nos resquícios de matadouros municipais e estaduais ainda existentes e nas ações clandestinas de abate “vara curta” ou "pau baixo” 119 - abastecer os açougues dos pequenos municípios e da periferia de cidades como Araçatuba, Andradina e Birigui.

\footnotetext{
${ }^{116}$ Em visita feita à região de Presidente Prudente, também no oeste do estado de São Paulo, viu-se caminhões de bois cruzando em frente ao frigorífico Better Beef, no município de Rancharia, sendo encaminhados à Promissão (Marfrig), localidade distante aproximadamente a 150 quilômetros.

${ }^{117}$ De 2002 a 2007, a boiada no estado de São Paulo passou de 14.120.734 para 11.869.175 cabeças; uma diminuição de quase $16 \%$ (Secretaria de Agricultura e Abastecimento do Estado de São Paulo/Coordenadoria de Defesa Agropecuária, 28/02/2008). Para o mesmo intervalo, a diminuição da área de terras paulistas direcionadas para pastagens foi de quase $10 \%$ (IEA, http://www.iea.sp.gov.br/out/banco/menu.php. Acesso Disponível em 27/08/2008).

${ }^{118}$ Exemplo desse processo, o grupo IFC desativou suas duas unidades entre 2006 e 2008 no oeste paulista, deslocando todas suas potencialidades à nova planta instalada no município de Nova Xavantina (MT), no Centro-Oeste do país.

${ }^{119}$ Termos populares usados como referências aos abates clandestinos na região.
} 
No que se refere às outras culturas agrícolas com ocupação no espaço geográfico regional, nesses anos de diminuição da hegemonia pecuária, ou seja, no discorrer da primeira década do século $\mathrm{XXI}^{120}$, obtiveram reajuste no espaçamento das terras agrícolas as culturas da soja, algodão, tomate, banana, borracha, coco e abacaxi $^{121}$. Reduziram áreas consideravelmente as culturas do arroz, feijão, goiaba, laranja e manga; e mantiveram ocupações em patamares parecidos no transcorrer dos anos a mandioca, o café, o milho e o sorgo. Esses dois últimos produtos, com demanda em alta para abastecer os confinamentos e semi-confinamentos, têm sido buscados no Centro-Oeste do país para suprir os estoques das casas de comércio agropecuário da região de Araçatuba.

${ }^{120} \mathrm{O}$ resultado dessa análise tem como base o banco de dados SIDRA/IBGE, para o intervalo dos anos de 2000-2006.

${ }^{121}$ Em visitas a algumas propriedades rurais na região, presenciamos o uso da cultura do abacaxi para a recuperação de pastagens. 


\section{Considerações Finais}

No ato de finalizar esse trabalho, primeiramente acreditamos ter contribuído cientificamente para a compreensão dessa porção territorial do espaço geográfico paulista. No que se refere aos diferentes momentos de ocupação das terras na região de Araçatuba, presenciamos a predominância de um uso hegemônico direcionado por demandas externas à configuração regional. Por mais que as parcelas técnicas introduzidas para a formatação dos elos dos circuitos produtivos no espaço geográfico estudado sempre estiveram sob o gerenciamento de uma elite provinciana, as parcelas políticas que direcionaram suas introduções surgiram sob os ditames e demandas de forças longínquas.

Sendo assim, mesmo gerando crescimento econômico, o que se visualiza diante dessa lógica perversa instaurada na dinâmica dos espaços geográficos locais ou regionais é uma concentração da riqueza social produzida nas mãos de poucos atores: sejam eles os que exercem o comando técnico in lócus ou os que no comando político-econômico, escoam a mais-valia para fora do lugar ou região. Resta aos atores subalternos uma fatia minúscula dessa riqueza gerada, ficando muitos no limite da sobrevivência.

Exemplificando para o momento atual, onde a expansão da canade-açúcar tem propiciado crescimento econômico na região de Araçatuba, com a geração de empregos diretos e indiretos ao setor, a parcela mais acolhida nesse processo, que são cortadores de cana, vivem, em sua maioria, em condições sub-humanas. Mesmo com os usineiros e suas entidades representantes - como a UDOP em Araçatuba - relatarem que o desrespeito à legislação trabalhista - onde o empregador não possibilita aos trabalhadores as condições mínimas normatizadas nas convenções coletivas entre as partes - ser um fenômeno irrisório no setor canavieiro ${ }^{122}$, pipocam na imprensa regional e nacional retratos que dão uma sensação de que a ilegalidade insalubre do trabalho no corte da cana-de-açúcar acontece em

${ }^{122}$ Segundo Antônio César Salibe, diretor-executivo da UDOP, segundo estimativas da entidade, na região de Araçatuba, somente 5\% da mão-de-obra no corte da cana-de-açúcar são contratadas fora dos ditames da legislação trabalhista. 
uma escala bem mais significativa. Cabe ao Estado, através de órgãos como o Ministério Público do Trabalho, aos estudiosos da questão social e aos próprios atores hegemônicos do setor ficarem mais atentos na quantificação e controle desses eventos, pois investigações de barreiras não-tarifárias relacionadas à questão social podem dificultar a efetivação do etanol brasileiro como um dos paradigmas energéticos alternativos no atual momento de preocupações ambientalistas. Atingir a competitividade a qualquer custo talvez não seja um bom negócio!

Contudo, nossos questionamentos diante dessa lógica perversa de expropriação e concentração da riqueza gerada nos lugares e nas regiões não perpassam apenas a “ilegalidade" de ações como as mencionadas acima. Novamente exemplificando a atividade canavieira nas redondezas de Araçatuba, presenciamos que os contratos de pagamento aos cortadores de cana e aos arrendatários donos das terras são basilados na flutuação do preço da tonelada da cana mês a mês. Diante de uma contabilidade onde as margens de lucro dos atores hegemônicos são sempre mantidas, milhares de pessoas vivem a instabilidade gerada pela especulação do mercado financeiro no qual o setor está inserido. Assim, a gestão dos lugares e regiões passa longe da grande maioria que os produzem com seu trabalho e neles sobrevivem. 


\section{BIBLIOGRAFIA}

ASSUMPÇÃO, R. “Desempenho da agricultura na década de 70”. Informações Econômicas, v. 14, n. 4, Secretaria da Agricultura e Abastecimento do estado de São Paulo, São Paulo, 1984.

BELIK, W. \& PAULILLO, L. F. “O Financiamento da Produção Agrícola Brasileira na década de 90: Ajustamento e Seletividade” publicado em Leite, S. (org.) Políticas Públicas e Agricultura no Brasil. Editora Universidade UFRGS, pp. 95-120, 2001.

BERTERO, J. F. "Estado, agricultura e agroindústria: estudo da base paulista da economia canavieira do Brasil entre 1948-1990”. Tese de Doutorado. FFLCH. USP. São Paulo, 1991.

BINI, D. L. de C. “A Mecanização na Lavoura Canavieira e suas Implicações Sócio-Territoriais na Região de Ribeirão Preto”. Trabalho de Graduação Individual. FFLCH. USP. São Paulo, 2003.

CAMARGO, A. M. M. P. de. "Substituição Regional entre as Principais Atividades Agrícolas no Estado de São Paulo”. Dissertação de Mestrado. ESALQ. Piracicaba, 1983.

CAMARGO, A. M. M. P. de. at al. "Dinâmica e Tendência da Expansão da Cana-de-açúcar sobre as Demais Atividades Agropecuárias, 2001-2006. Informações Econômicas, v. 38, n. 03, mar. 2008, Secretaria da Agricultura e Abastecimento do estado de São Paulo, São Paulo, 2004.

CAMARGO, J. M. “Tecnificação da cana-de-açúcar em São Paulo e sazonalidade da mão-de-obra”. Dissertação de Mestrado. FEA. USP. São Paulo, 1988. 
CARVALHO, F. C. et al. "Avaliação do potencial agroindustrial das divisões regionais agrícolas de Araçatuba e Presidente Prudente, estado de São Paulo”, Agricultura em São Paulo, vol. 39, supl. 1, Secretaria da Agricultura e Abastecimento do estado de São Paulo, Instituto de Economia Agrícola (IEA), São Paulo, 1992.

CASTILLO, R. A. "Sistemas orbitais e uso do território: Integração eletrônica e conhecimento digital do território brasileiro”. Tese de Doutorado. FFLCH. USP. São Paulo, 1999.

CAVENAGHI, A. J. “Olhos do barão, boca do sertão: uma pequena história da fotografia e da cartografia no noroeste do território paulista (da segunda metade do século XIX ao início do século XX)”. Tese de Doutorado. FFLCH. USP. São Paulo, 2004.

COSTA, L. B. \& WONG, L. R. “Análise Demográfica Regional - Região de Araçatuba: Uma Área de Esvaziamento Populacional?”. SEADE. São Paulo, 1992.

DALLA COSTA, A. J. “O grupo Sadia e a produção integrada”. O lugar do agricultor no complexo agroindustrial. Dissertação de Mestrado. Curitiba :UFPR, 1993.

DE ZEN, S. “Integração entre os Mercados de Boi Gordo e de Carne Bovina nas Regiões Centro-Oeste e Sudeste do Brasil”. Dissertação de Mestrado. ESALQ. Piracicaba, 1997.

ELIAS, D. “Meio Técnco-Científico-Informacional e Urbanização na região de Ribeirão Preto (SP)”. Tese de Doutorado. Departamento de Geografia. FFLCH. USP. São Paulo, 1996.

ESPÍRITO SANTO, C. R. "Dinâmica do Desenvolvimento Rural na Região de Araçatuba (SP)”. Tese de Doutorado. FCT. UNESP. Presidente Prudente, 2005. 
FARINA, E. M. M. Q. "Reflexões sobre a desregulamentação e sistemas agroindustriais: a experiencia brasileira”. Tese de Livre-Docência, FEA, USP, São Paulo, 1996.

FALLEIROS, A. "Mirandópolis: Sua evolução no Século XX”. Gráfica Dom Bosco, Três Lagoas, 1999.

FERREIRA, C. R. R. P. T. et al. "Alguns Aspectos do Uso Econômico das Pastagens no Estado de São Paulo”. Agricultura em São Paulo, Instituto de Economia Agrícola, Secretaria da Agricultura e Abastecimento do Estado de São Paulo, São Paulo, 1990.

FISCHER, A. L. "Impactos Sociais do Proálcool: Um Estudo Sobre as Relações, o Processo e as Condições de Trabalho na Agroindústria Canavieira Paulista”. Dissertação de Mestrado. PUC. São Paulo, 1992.

FOLHA DA REGIÃO. "Cresce transporte de açúcar por ferrovia". 28/09/2007. http://www.folhadaregiao.com.br/noticia?76916. Acesso Disponível em 02/10/2008. Araçatuba, 2007. . “Usinas já atraem oito empresas”. 09/03/2004. pág.

A5. Araçatuba, 2004.

. “Consumo na indústria cresce quase 12\%”. 27/12/2007. http://www.folhadaregiao.com.br/noticia?82210. Acesso Disponível em 02/10/2008. Araçatuba, 2007. "Movimento no aeroporto aquece economia local”. 12/05/2007. http://www.folhadaregiao.com.br/noticia?67849. Acesso Disponível em 02/10/2008. Araçatuba, 2007.

FURTADO, C. “Formação Econômica do Brasil”. Fundo de Cultura. Rio de Janeiro, 1959. 
GASQUES, J. G. \& VILLA VERDE, C. “Crescimento da agricultura e política agrícola nos anos oitenta”. IPEA, nov. 1990, (Texto para Discussão, 204), Brasília, 1990.

GHIRARDELLO, N. “À beira da linha: formações urbanas da noroeste paulista” - Tese de Doutorado - Faculdade de Arquitetura e Urbanismo (FAU), USP, São Paulo, 1999.

GOMES, M. T. S. “O Processo de Reestruturação Produtiva em Cidades Médias do Oeste Paulista: Araçatuba, Birigui, Marília, Presidente Prudente e São José do Rio Preto”. Tese de Doutorado. FFLCH. USP. São Paulo, 2007.

GONÇALVES, J. S. \& SOUZA, S. A. M. \& VICENTE, J. R. "Comércio Exterior dos Agronegócios Brasileiros: desempenho dos principais grupos de cadeias de produção, 1997-2003”. Informações Econômicas, v. 34, n. 12, dez. 2004, Secretaria da Agricultura e Abastecimento do estado de São Paulo, São Paulo, 2004.

HASEGAWA, M. M. “O Mercado de Reposição da Pecuária Bovina de Corte no Estado de São Paulo”. Dissertação de Mestrado. ESALQ. Piracicaba, 1995.

HERNÁNDEZ, J. L. S. “El eje Irún-Aveiro: Geografía de un eje de desarrollo”. Salamanca, 1998.

HESPANHOL, A. N. "Dinâmica Agroindustrial, Intervenção Estatal e a Questão do Desenvolvimento da Região de Andradina - SP”. Tese de Doutorado. UNESP, Rio Claro, 1996.

HOLANDA, S. B. de. "Caminhos e Fronteiras". Companhia das Letras. $3^{\mathrm{a}}$ edição. São Paulo, 1994. 
IAA. "Relatório/1981”. Ministério da Indústria e do Comércio. Instituto do Açúcar e do Álcool. Rio de Janeiro, 1981.

IBMEC. "Política Monetária e Dívida Pública”. Instituto Brasileiro de Mercado de Capitais. Brasília, 1974.

IGREJA, A. C. M. "Evolução da Pecuária Bovina de Corte no Estado de São Paulo (1969-1984)”. Dissertação de Mestrado. ESALQ. Piracicaba, 1987.

KAGEYAMA, A. “O Novo Padrão Agrícola Brasileiro: do Complexo Rural aos Complexos Agroindustriais”. In: Delgado, G. C. Agricultura e Políticas Públicas. págs. 113-223. IPEA. Brasília, 1990.

KUME, H. (1996) "Política de Importação no Plano Real e a Estrutura de Proteção Efetiva”. Texto para Discussão Ipea, n. ${ }^{\circ}$ 423, Rio de Janeiro: Ipea.

KURZ, R. “O colapso da modernização: Da derrocada do socialismo de caserna à crise da economia mundial”. Paz e Terra, São Paulo, 1999.

MAGNOLI, D. M. “Corpo da Pátria: Imaginação Geográfica e Política Externa no Brasil (1808-1912)”. Tese de Doutorado. Departamento de Geografia. FFLCH. USP. São Paulo, 1996.

MANNARELLI FILHO, T. “Estudo da Análise de Investimento na Cultura da Cana na Região Oeste do Estado de São Paulo”. Economia \& Pesquisa, Fundação Educacional de Araçatuba, Araçatuba, 2003.

MANFREDI NETO, P. “O trem da morte - o imaginário do progresso na Noroeste (1905-1930)”. Dissertação de Mestrado. FFLCH. USP. São Paulo, 1995. 
MARTIN, N. B. \& TOYAMA, N. K. \& PIRES, Z. A “Análise Econômica da Produtividade dos Recursos na Pecuária de Corte no Estado de São Paulo”. Agricultura em São Paulo. Instituto de Economia Agrícola. Secretaria da Agricultura do Estado de São Paulo. São Paulo, 1977.

MARTINE, G. “O Novo Padrão Agrícola Brasileiro: Do Complexo Rural aos Complexos Agroindustriais”. Mimeo, 1987.

MARTINS, J. S. “O cativeiro da terra”. Hucitec. 6a edição. São Paulo, 1996. - "Fronteira: a degradação do outro nos confins do humano”. Hucitec. São Paulo, 1997.

MARTINS, O. \& RAMOS, D. S. “A Cidade-pérola em Capítulos”. Tipografia Noroestina Ltda. Araçatuba, 1961.

MARTINS, S. S. et al. "Novas configurações da Agropecuária Paulista”. Informações Econômicas, v. 36, n. 10, Secretaria da Agricultura e Abastecimento do estado de São Paulo, São Paulo, 2006.

MENEZES, A. M. F. \& FONSECA, M. J. M. “A mundialização do capital e seus rebatimentos na economia brasileira: análises do processo de abertura econômica e de privatização”. Bahia Análises \& Dados, v. 13, n. 1, p. 0921, UFBA, Salvador, 2003.

MONBEIG, P. “Pioneiros e fazendeiros de São Paulo”. 2ª edição. HucitecPolis. São Paulo, 1998. 
MORAES, M. A. F. D. “Desregulamentação da agroindústria canavieira: novas formas de atuação do estado e desafios do setor privado”. In Moraes, M. A. D \& Shikida, P. F. A. (org.) - Agroindústria Canavieira no Brasil: evolução, desenvolvimento e desafios - Atlas, São Paulo, 2002.

“A Desregulamentação do Setor Sucroalcooleiro do Brasil”. Caminho Editorial. Americana, 2000.

MUSSOLINI, G. “Os meios de Defesa contra a Moléstia e a Morte em duas Tribos Brasileiras - Kaingangues e Bororo” Dissertação de Mestrado. ESP. USP. 1946.

NEGRI, B. "Desconcentração da indústria paulista nos últimos vinte anos (1970-1990)”. Anais do XXI Encontro Nacional de Economia, Campos do Jordão, 1992.

. “Concentração e desconcentração industrial em São Paulo, (1880-1990)”. Unicamp, Campinas, 1996.

NOGUEIRA, A. R. “A Imigração Japonesa para a Lavoura Cafeeira Paulista (1908-1922)”. Instituto de Estudos Brasileiros (IEB). São Paulo, 1973.

OLIVETTE, M. P. A. et al. "Comportamento regional da área e da produtividade agrícola no estado de São Paulo, 1983-2002”. Informações Econômicas, v. 33, n. 06, jun. 2003, Secretaria da Agricultura e Abastecimento do estado de São Paulo, São Paulo, 2003.

PÁDUA, E. M. M. “Metodologia de Pesquisa: Abordagem TeóricoPrática”. Papirus. Campinas, 1996. 
PÁEZ, M. L. D. "Parque industrial de carnes: característica e eficiência das unidades abatedoras de bovinos do estado de São Paulo” - Agricultura em São Paulo, Ano XXII, Tomo I e II - Secretaria da Agricultura do estado de São Paulo, São Paulo, 1975.

PAIVA, R. M. "Setor agrícola do Brasil: comportamento econômico, problemas e possibilidades”. Editora Forense-Universitária. Rio de Janeiro, 1976.

. “Apreciação Geral sobre o Comportamento da Agricultura Brasileira” In ARAÚJO, P. F. C \& SCHUH, G. E. “Desenvolvimento da Agricultura: Estudos de Casos”. Livraria Pioneira. São Paulo, 1983, pp. 155-212.

PEREIRA, L. C. B. “A Crise do Estado: Ensaios sobre a economia brasileira”. Nobel. São Paulo, 1992.

PEREZ, M. C. R. C. "Contribuição ao estudo da elasticidade-renda do consumo de alimentos”. Dissertação de Mestrado. ESALQ. Piracicaba, 1973.

PIGATTO, G. "Determinantes da Competitividade da Indústria de Carne Bovina do Estado de São Paulo”. Dissertação de Mestrado. UFSCAR. São Carlos, 2001.

PINHEIRO, F. A. “A Renda e o Preço da Terra: Uma Contribuição à Análise da Questão Agrária Brasileira”. Tese de Livre-Docência. ESALQUSP. Piracicaba, 1980.

PINHEIRO, C. \& BODSTEIN, O. "História de Araçatuba”. Academia Araçatubense de Letras. Araçatuba, 1997. 
PINO, F. A. \& VICENTE, J. R. “Composição do rebanho bovino leiteiro, Estado de São Paulo”. Informações Econômicas, São Paulo, v. 10, n. 8, p. 3739, ago. 1980.

PRADO JR, C. “Formação do Brasil Contemporâneo”. Brasiliense. São Paulo, 1948. . "História Econômica do Brasil”. 42 ${ }^{\mathrm{a}}$ ed.. São Paulo, Brasiliense, 1994.

QUEIROZ, P. R. C. "Uma ferrovia entre dois mundos: a E.F. Noroeste do Brasil na construção histórica de Mato Grosso (1918-1956)”. Tese de Doutorado. FFLCH. USP. São Paulo, 1999.

RAMOS, S. F. “Uso do território brasileiro e sistemas técnicos agrícolas: a fruticultura irrigada em Petrolina (PE)/Juazeiro (BA)”. Dissertação de Mestrado, FFLCH, USP, São Paulo, 2001.

REGO, M. T. R. "Proálcool na região de Araçatuba: o doce fel do binômio cana-boi”. Tese de Doutorado. FFLCH, USP, São Paulo, 1990.

ROCHA FILHO, R. “Comparação de Rentabilidade em Propriedade com Pecuária de Corte e Cultivo da Cana-de-açúcar”. Estágio Profissionalizante em Engenharia Econômica. Departamento de Economia, Administração e Sociologia. ESALQ. USP. Piracicaba, 2006.

ROSSINI, R. E. “Geografia e Gênero: A mulher na lavoura canavieira paulista”. tese de livre-docência. FFLCH. USP. São Paulo, 1988.

SAES, F. A. M. de. “As ferrovias de São Paulo: 1870-1940”. Hucitec. São Paulo, 1981. 
SANTOS, M. “Por Uma Geografia Nova”. Hucitec. São Paulo, 1978.

. “Metamorfoses do Espaço Habitado”. Hucitec. São

Paulo, 1988.

. “Técnica, espaço, Tempo: globalização e meio técnicocientífico-informacional”. Hucitec, São Paulo, 1994.

• “A Urbanização Brasileira”. Hucitec, São Paulo,

1994b.

. “Por uma outra globalização”. Record. São Paulo, 2000.

"Natureza do Espaço: técnica e tempo, razão e emoção”. Editora da Universidade de São Paulo. São Paulo, 2002.

. "O espaço dividido: os dois circuitos da economia urbana dos paises subdesenvolvidos”. Editora da Universidade de São Paulo. São Paulo, 2002b.

“Economia Espacial: Críticas e Alternativas”. Editora da Universidade de São Paulo. São Paulo, 2003.

SANTOS, M. \& SILVEIRA, M. L. "O Brasil: Território e Sociedade no Início do Século XXI”. Editora Record. Rio de Janeiro, 2001.

SAYAD, J. "Preço da Terra e Mercados Financeiros". Pesquisa e Planejamento Econômico, vol. 7, nº. 3, São Paulo, Dez. 1977, pp. 623-662.

SCHUH, E. G. “Modernização da Agricultura Paulista”. In ARAÚJO, P. F. C \& SCHUH, G. E. "Desenvolvimento da Agricultura: Análise de Política Econômica”. Livraria Pioneira. São Paulo, 1977, pp. 281-311. 
SILVA, J. G. "Progresso técnico e relações de trabalho na agricultura". Editora Hucitec. São Paulo, 1981.

SILVEIRA, M. L. "Totalidade e fragmentação: o espaço global, o lugar e a questão metodológica, um exemplo argentino”. In: O Novo Mapa do Mundo: Fim de Século e Globalização. Org: Maria Adélia de Souza, Milton Santos, Francisco Capuano Scarlato e Mônica Arroyo, Editora Hucitec/ANPUR, São Paulo, 1997. . "Um País, Uma Região: Fim de século e modernidades na Argentina”. FAPESP. São Paulo, 1999.

SMITH, G. W. “A Política Agrícola Brasileira: 1950-1967”. In ARAÚJO, P. F. C \& SCHUH, G. E. "Desenvolvimento da Agricultura: Estudos de Casos”. Livraria Pioneira. São Paulo, 1983, pp. 213 - 256.

SODRÉ, N. W. “Oeste: Ensaio Sobre a Grande Propriedade Pastoril”. Arquivo do Estado de São Paulo. São Paulo, 1990.

SORJ, B. "Camponeses e Agroindústria: Transformação social e representação política na avicultura brasileira.”. Ed. Zahar. Rio de Janeiro, 1982.

SPOSITO, M. E. B. "As cidades médias e os contextos econômicos contemporâneos”. in SPOSITO, Maria E. B. (org) Urbanização e cidades: perspectivas geográficas. Presidente Prudente: (s.n), 2001.

SUZIGAN, W. "Indústria brasileira: origem e desenvolvimento". Brasiliense. São Paulo, 1986.

SZMRECSÁNYI, T. \& RAMOS, P. “O papel das políticas governamentais na agricultura brasileira”. In: SZMRECSÁNYI, T. \& SUZIGAN, W. (Orgs.). História econômica do Brasil contemporâneo. Hucitec, São Paulo, 1997. p.227-249. 
THOMAZ JR, A. "Por trás dos canaviais: os (nós) da cana. (Uma contribuição ao entendimento da relação capital x trabalho e do movimento sindical dos trabalhadores na agroindústria canavieira paulista)”. Tese de Doutorado. FFLCH. USP. São Paulo, 1996.

TIGRE, P. B. “Informática como base técnica do novo paradigma”. São Paulo em Perspectiva, 7(4):26-33, SEADE, dezembro-setembro, São Paulo, 1993.

TOLEDO, J. C. \& SALIBE, A. C. "Perspectivas de Crescimento do Setor de Bioenergia no Oeste Paulista”. Apresentação PowerPoint. UDOP. Araçatuba, Maio/2007.

TORQUATO, S. A. \& PEREZ, L. H. "Evolução das Exportações Brasileiras de Álcool, Período de 1996 a Julho de 2005”. Informações Econômicas, v. 36, n. 3, mar. 2006, Secretaria da Agricultura e Abastecimento do estado de São Paulo, São Paulo, 2006.

TOYAMA, N. K. \& MARTIN, N. B. \& TACHIZAWA, E. H. “A Pecuária Bovina de Corte no Estado de São Paulo”. Agricultura em São Paulo. Instituto de Economia Agrícola. Secretaria da Agricultura do Estado de São Paulo. São Paulo, 1976.

TSUNECHIRO, A. et al. "Valor da produção Agropecuária do estado de São Paulo em 2005”, Informações Econômicas, v.36, n. 4, abr. 2006, Secretaria da Agricultura e Abastecimento do estado de São Paulo, São Paulo, 2006.

VASCONCELOS, C. L. M. "Pecuária Bovina na Região de Araçatuba: Intensificação da Produção de Substituição por Outras Atividades Agropecuárias”. Trabalho de Graduação. UNESP. Jaboticabal, 1982. 
VASCONCELOS, L. A. T. "Desenvolvimento econômico e urbanização nas Regiões Administrativas de São José do Rio Preto e de Araçatuba”. Dissertação de Mestrado - Instituto de Economia, Universidade Estadual de Campinas, Campinas, 1992.

VEIGA FILHO, A. - "Fatores explicativos da mecanização do corte na lavoura canavieira paulista”, in Informações Econômicas. volume 28, $\mathrm{n}^{0}$ 11, Instituto de Economia Agrícola, Secretaria da Agricultura e do Abastecimento do Estado de São Paulo, São Paulo novembro/1998.

VEIGA FILHO, A. A. \& MATSUNAGA, M. \& YOSHII, R. J. "Proposta de Redirecionamento do Proálcool: Uma Pauta para Discussão”. Informações Econômicas, Secretaria da Agricultura e Abastecimento do Estado de São Paulo, São Paulo, Dezembro/1987.

WAIBEL, L. “Capítulos de Geografia tropical e do Brasil”. 2ª edição. IBGE. Rio de Janeiro, 1979.

YOSHII, R. J. \& MATSUNAGA, M. “Comentários sobre o Programa Nacional do Álcool e a Produção de Alimentos”. Informações Econômicas. Instituto de Economia Agrícola. Secretaria de Agricultura e Abastecimento. São Paulo, Agosto/1984.

ZAMPIERI, H. "Birigui, cidade industrial do oeste paulista: um núcleo recente de fabricação do calçado”. Dissertação de Mestrado, FFLCH, USP, São Paulo, 1976. 